\title{
Pirandello e a máscara animal
}

Tese apresentada ao Programa de Pós-Graduação em Língua, Literatura e Cultura Italianas do Departamento de Letras Modernas da Faculdade de Filosofia, Letras e Ciências Humanas da Universidade de São Paulo para obtenção do título de Doutor em Língua, Literatura e Cultura Italianas.

Área de Concentração: Língua, Literatura e Cultura Italianas.

Orientador: Profa. Dra. Lucia Wataghin

São Paulo

2014 
AUTORIZO A REPRODUÇÃO E DIVULGAÇÃO TOTAL OU PARCIAL DESTE TRABALHO, POR QUALQUER MEIO CONVENCIONAL OU ELETRÔNICO, PARA FINS DE ESTUDO E PESQUISA, DESDE QUE CITADA A FONTE.

Catalogação na Publicação

Serviço de Biblioteca e Documentação

Faculdade de Filosofia, Letras e Ciências Humanas da Universidade de São Paulo.

\footnotetext{
Degani, Francisco José Saraiva

D317p Pirandello e a máscara animal / Francisco José Saraiva Degani; orientador Lucia Wataghin - São Paulo, 2014.

$192 \mathrm{f}$.

Tese (Doutorado) - Faculdade de Filosofia, Letras e Ciências Hu manas da Universidade de São Paulo. Departamento de Letras Modernas. Área de concentração: Língua, Literatura e Cultura Italianas.
}

1. Luigi Pirandello. 2. Novelas. 3. Literatura italiana. 4. Zooliteratura. 


\section{FOLHA DE APROVAÇÃO}

Francisco José Saraiva Degani

Título: Pirandello e a máscara animal

Tese apresentada ao Programa de Pós-Graduação em Língua, Literatura e Cultura Italianas do Departamento de Letras Modernas da Faculdade de Filosofia, Letras e Ciências Humanas da Universidade de São Paulo para obtenção do título de Doutor em Língua, Literatura e Cultura Italianas.

Área de Concentração: Língua, Literatura e Cultura Italianas.

Aprovado em:

Banca Examinadora

Prof. Dr.:

Instituição: Assinatura:

Prof. Dr.:

Instituição: Assinatura:

Prof. Dr.:

Instituição: Assinatura:

Prof. Dr.:

Instituição: Assinatura:

Prof. Dr.:

Instituição: Assinatura: 
DEDICATÓRIA

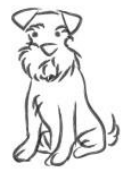

Ao outro Luigi, outra vez. 


\section{AGRADECIMENTOS}

À Profa. Dra. Lucia Wataghin, por esta e outras oportunidades.

Ao meu filho, Rodrigo, pelas ilustrações.

Aos professores, familiares e amigos que não permitiram que eu perdesse o fôlego na longa jornada que foi chegar até aqui.

Aos bichos que se apresentaram para guiar o meu caminho.

Sinceramente. 
RESUMO

DEGANI, F. Pirandello e a máscara animal. 2014. 192 f. Tese (Doutorado) - Faculdade de Filosofia, Letras e Ciências Humanas, Universidade de São Paulo, São Paulo, 2014.

A obra em prosa de Luigi Pirandello (1867-1936), sobretudo sua novelística, é permeada pela presença de um rico e variado mundo animal. O autor, como um agudo observador de sua época, reconhece a importância dos animais na cultura e no desenvolvimento da civilização. Espelhos naturais dos humanos, capazes de sofrer e entender esse sofrimento, agentes do acaso e da impassibilidade da natureza, os animais inserem-se perfeitamente na poética do autor. Em Pirandello, o animal é um personagem que age e se comporta como um personagem de Pirandello, mas, ao contrário do personagem humano, mostra a sua própria face, sem disfarces, sem meios termos e sem máscaras. Este estudo busca examinar e chamar a atenção para esse pouco estudado, mas importante aspecto da obra de Pirandello, relacionando-o com a poética do autor e a evolução de sua obra.

Palavras chave: 1. Luigi Pirandello. 2. Novelas. 3. Literatura italiana. 4. Zooliteratura. 


\section{ABSTRACT}

DEGANI, F. Pirandello and the animal mask. 2014. 192 f. Thesis (Doctorate) - Faculdade de Filosofia, Letras e Ciências Humanas, Universidade de São Paulo, São Paulo, 2014.

The prose works of Luigi Pirandello (1867-1936), particularly his short stories, is permeated by the presence of a rich and varied animal world. The author, as a keen observer of his time, recognizes the importance of animals in the culture and development of civilization. Natural mirrors of the human being, capable of suffering and understanding this suffering, agents of nature's chance and impassivity, animals fall perfectly into the poetics of the author. In Pirandello, the animal is a character who acts and behaves like a character from Pirandello, but, unlike the human character, it shows its own face, without disguises, compromises and masks. This study seeks to examine and draw attention to this understudied but important aspect of the work of Pirandello, relating it to the poetics of the author and the evolution of his work.

Keywords: 1. Luigi Pirandello. 2. Short stories. 3. Italian literature. 4. Zooliterature. 


\section{RIASSUNTO}

DEGANI, F. Pirandello e la maschera animale. 2014. 192 f. Tesi (Dottorato) - Faculdade de Filosofia, Letras e Ciências Humanas, Universidade de São Paulo, São Paulo, 2014.

L'opera in prosa di Luigi Pirandello (1867-1936), soprattutto la sua novellistica, è permeata dalla presenza di un ricco e variato mondo animale. L'autore, come un acuto osservatore della sua epoca, riconosce l'importanza degli animali nella cultura e nello sviluppo della civilizzazione. Specchi naturali degli esseri umani, capaci di soffrire e capire questa sofferenza, agenti del caso e dell'impassibilità della natura, gli animali si inseriscono perfettamente nella poetica dell'autore. In Pirandello, l'animale è un personaggio che agisce e si comporta come un personaggio di Pirandello, ma, al contrario del personaggio umano, mostra la sua vera faccia, senza mimetismo, senza mezzi termini e senza maschere. Questo studio cerca di esaminare e porre l'attenzione su questo poco studiato ma importante aspetto dell'opera di Pirandello, mettendolo in relazione con la poetica dell'autore e l'evoluzione della sua opera.

Parole chiavi: 1. Luigi Pirandello. 2. Letteratura italiana. 3. Novella. 4. Zoolitteratura. 


\section{Notas de Leitura}

- Neste trabalho foram utilizadas as indicações das "Diretrizes para apresentação de dissertações e teses da USP: documento eletrônico e impresso" disponível no endereço eletrônico http//www.teses.usp.br/info/diretrizesfinal.pdf.

- As referências bibliográficas estão de acordo com a normalização International Standard Organization (ISO) - ISSO 690 e ISO 690.2.

- A data entre parêntesis, junto ao título de cada novela citada, refere-se ao ano da primeira publicação, pois não há dados suficientes para identificar com certeza o ano em que cada uma delas foi escrita.

- O Anexo A contém uma relação das novelas escritas por Pirandello, organizada pelo ano da primeira publicação.

- Os títulos dos romances e das novelas de Pirandello estão em português, mesmo quando não há tradução no Brasil.

- Os títulos dos livros de poesia estão no original com a tradução entre colchetes ao lado.

- Todas as citações e os trechos de novelas citadas estão em português com o original transcrito em nota. As traduções são de minha autoria, exceto quando indicado o contrário.

- As referências bibliográficas das novelas citadas estão indicadas no Anexo B. 

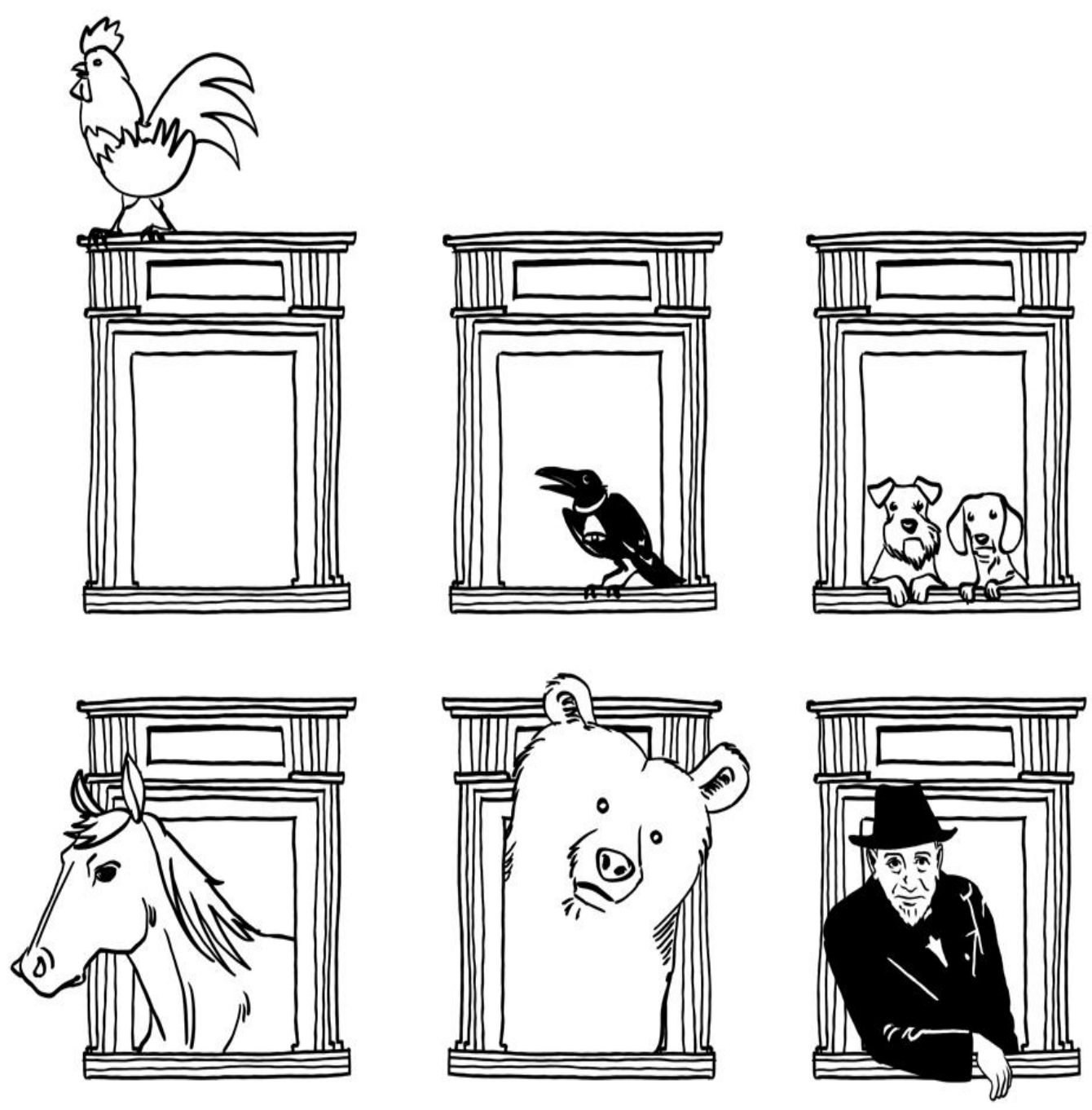

Pirandello e a máscara animal 


\section{Sumário}

\section{Prólogo}

2. Luigi Pirandello: biografia e autobiografia

3. A lição de Esopo

a) Le favole di Messer Renardo.

b) A fábula dentro da narrativa

c) Metamorfoses

4. A máscara animal

a) o animal e o espelho

b) o animal e o humano

c) o animal, o campo e a cidade

d) o animal e o acaso

e) o animal nas últimas novelas

5. Um bestiário (im)possível, a título de conclusão.

Referências bibliográficas

Anexo A: Novelas por ano de publicação.

Anexo B: Refe rências bibliográficas das novelas citadas. 
As novas gerações de escritores deverão retomar, cada qual na medida de seu talento, a inventiva tarefa que começou com Esopo, ou mesmo antes dele, de reunir os animais que pela Terra andam e hão de andar perenemente. ${ }^{1}$

\footnotetext{
${ }^{1}$ MONTERROSO, Augusto. Apud:BUENO, Wilson. Jardim Zoológico. São Paulo: Iluminuras, 1999, p. 9.
} 


\section{Prólogo}

Os filósofos erraram em não pensar nos animais, e diante dos olhos de um animal desmorona como um castelo de cartas qualquer sistema filosófico. ${ }^{2}$

\footnotetext{
2 "I filosofi hanno il torto di non pensare alle bestie e davanti agli occhi di una bestia crolla come un castello di carte qualunque sistema filosofico." PIRA NDELLO, Luigi. "Foglietti", In Saggi, Poesie e Scritti varii. Milano: Arnoldo Mondadori Editore, 1993, p. 1270.
} 
O que seria do homem sem os animais? Desde sempre eles acompanham a trajetória do ser humano. Precedendo seu surgimento, os animais sempre participaram do cotidiano do homem, estimularam sua imaginação, ajudaram-no no trabalho, fizeram-lhe companhia e garantiram sua sobrevivência. A identidade humana está ligada, em grande parte, aos animais. Eles são cúmplices de nossa existência, transmitindo-nos sua experiência e seu afeto. É por intermédio deles, selvagens ou domésticos, que somos capazes de interagir com a natureza que nos cerca e da qual muitas vezes esquecemos que fazemos parte.

Por outro lado, o que seria do imaginário e da literatura sem o animal? A figura do animal pode ser encontrada nas pinturas rupestres das cavernas pré-históricas, nas narrativas orais, nos primeiros escritos da humanidade e até nas mensagens enviadas às estrelas em duas missões das naves Voyager.

$\mathrm{Na}$ história da literatura ocidental, o animal foi inicialmente retratado de forma simbólica, como paradigma das virtudes e vícios humanos, nas fábulas de Esopo, ou então de forma enciclopédica e científica, ou pseudocientífica, em Aristóteles, Plínio o Velho, Santo Isidoro e no famoso Physiologus ${ }^{3}$. Este último, mais tarde, serviu de base para os bestiários medievais, cuja principal função era dar instrução religiosa e moralizante aos noviços dos monastérios, por meio de símbolos, alegorias e analogias com o mundo animal. Ou seja, nos

\footnotetext{
${ }^{3}$ Trata-se da História dos Animais de Aristóteles, História Natural de Plínio o Velho, Etimologias de Santo Isidoro. O Physiologus é de autoria incerta, provavelmente escrito no século II, em Alexandria.
} 
primeiros séculos de sua existência, a literatura ocidental entra como que num círculo vicioso que se retroalimenta, indo buscar na filosofia e na ciência elementos para a moralidade e a imaginação, enquanto a ciência e a filosofia se valem da literatura para justificar algumas de suas descobertas, numa tentativa de explicar e catalogar o mundo que nos cerca.

Isso tudo, entretanto, sem dissociar o mundo animal do mundo humano, pois o animal é fonte de trabalho, alimentação, companhia e até mesmo lazer para o homem. Basta pensar nas caçadas, nas corridas e jogos que incluem animais.

É a partir do século 17, com Descartes, que ocorre um primeiro afastamento entre os dois mundos, no ocidente. Considerado como pioneiro do pensamento moderno, Descartes vê o homem como animal racional, já que é provido de consciência e de linguagem, enquanto o animal, por não possuir essas características, passa a ser encarado como um simples mecanis mo à disposição do homem. O animal, então,

esvaziado de seus enigmas e sortilégios, passa a ser enfocado com critérios científicos bem definidos, seja sob os imperativos de uma taxonomia rigorosa, como a de Lineu, seja pelo surgimento das ciências de observação e experimentação que precederam o surgimento de zoológicos na Europa. ${ }^{4}$

Sobre o ponto de vista cartesiano, afirma Benedito Nunes: "O animal é o que de mais estranho a nós se torna. É o grande Outro porque, segundo o filósofo, é um corpo sem alma, um simples mecanismo."5

Mais tarde, Hegel, ao recuperar a consciência como "espírito objetivo" das criaturas vivas, identifica o animal com o mais baixo que pode haver dentro do homem, como a fera indomada que é recalcada, pela cultura, dentro do humano, aumentando ainda mais o abismo criado pela filosofia entre o homem e o animal.

\footnotetext{
${ }^{4}$ MACIEL, Maria Esther. Animais escritos - Notas de zooliteratura contemporânea. Palestra proferida na FFLCH-USP em 23 de outubro de 2012 (inédito).

5 NUNES, Benedito. "O animal e o primitivo: os outros de nossa cultura". In Pensar/escrever o animal. Ensaios de zoopoética e biopolítica. Florianópolis: Editora UFSC, 2011, p. 14.
} 
A difícil reconquista da proximidade perdida parece se iniciar com a constatação de Schopenhauer de que ambos, homem e animal, estão sujeitos à dor, ambos sofrem; a única diferença é que o homem é um animal metafísico, ou seja, ele percebe seu sofrimento. O sofrimento, então, seria o ponto de contato entre esses mundos.

O fato é que, para além das intrincadas relações homem/animal da filosofia do século XIX, em que também se pode incluir a afirmação de Heidegger, no século seguinte, de que o animal, ao contrário do homem, é pobre de mundo e rico de ambiente ${ }^{6}$, a literatura, desde a decadência dos bestiários, praticamente ignora a presença desse "grande Outro", e, quando não o faz, limita-se a servir-se dele ainda como exemplo moral ou como alegoria, remetendo ao imaginário dos bestiários e das fábulas, ou como complemento da paisagem.

A grande virada da revolução darwiniana, com a publicação de A origem das espécies, em 1859, resgata o animal de seu ostracismo literário, na medida em que o identifica, pela evolução, ao humano. Ou seja, o animal até então exterior ao homem ou, no máximo, responsável por seus mais baixos instintos, revela-se parte inegável de sua natureza. $\mathrm{O}$ homem, aos poucos, começa a tomar consciência de uma parcela animal, não mais recalcada em seu âmago, mas presente em seu comportamento e em suas emoções ${ }^{7}$, abrindo "um novo horizonte para se pensar as relações entre o humano e o não humano."8

Mesmo assim, afirma Benedito Nunes:

O animal continua sendo o grande Outro, o maior alienado da nossa cultura, "exceto que essa cultura, aumentando nosso conhecimento, talvez possa algum dia restabelecer os estreitos laços que a ele nos unia nos tempos

\footnotetext{
${ }^{6}$ Para Heidegger, o animal reage apenas ao mundo ao seu redor (ambiente), ele não consegue vivenciar-se separado dele. Enquanto o ser hu mano consegue, partindo de si, distinguir-se dos outros; e não apenas pode se relacionar com coisas distinguíveis, mas pode fazer distinções entre as coisas. Daí o animal ser pobre de mundo e rico de ambiente e o homem ser rico de mundo e pobre de ambiente. Ou seja, o animal pertence à natureza e o homem à sociedade.

${ }^{7}$ Muito dessa tomada de consciência deve-se mais u ma vez a Charles Darwin, com a publicação, em 1872 , de $A$ expressão das emoções no homem e nos animais.

${ }^{8}$ MACIEL, Maria Esther. Animais escritos - Notas de zooliteratura contemporânea. Palestra proferida na FFLCH-USP em 23 de outubro de 2012 (inédito).
} 
mitológicos, mas quando isso acontecer - comenta Elias Canetti - já quase não haverá animais entre nós."9

O que não invalida o fato de que o animal passa, então, a ser observado com mais atenção e a participar da literatura com sua genuína fisionomia, já então "privado [...] do valor de exemplum moral ou da veste sacra e fantástico-simbólica, própria da tradição alegórica."10 Afirma Maria Esther Maciel:

Como atestam obras de escritores de várias nacionalidades e linhagens, o universo zooliterário que se formou ao longo do século $\mathrm{XX}$ e início do século XXI é vasto e cheio de matizes. Nele podemos encontrar desde a sondagem fantasiosa (e por vezes erudita) do comportamento e dos traços constitutivos dos bichos de várias espécies, realidades e irrealidades, passando por abordagens que buscam antropomorfizá-los e convertê-los em metáforas do humano, até discussões éticas em torno das controversas relações de poder que os homens têm mantido com eles ao longo dos tempos. A que se soma ainda o trabalho que, avessos à ideia de circunscrever os animais aos limites da mera representação, buscaram flagrá-los também fora desses contornos, optando por uma espécie de compromisso afetivo ou de aliança com eles. Neste caso, cada animal - tomado em uma insubstituível singularidade - passa a ser visto como um suje ito dotado de inteligência, sensibilidade, competências e saberes diferenciados sobre o mundo ${ }^{11}$

Um dos primeiros autores ocidentais a incorporar os animais de forma não alegórica em suas narrativas foi Luigi Pirandello. Sua ascendência siciliana, um mundo ainda arcaico no final do século XIX, certamente contribuiu para um contato íntimo com os animais. A leitura

\footnotetext{
${ }^{9}$ NUNES, Benedito. “O animal e o primitivo: os outros de nossa cultura”. In Pensar/escrever o animal. Ensaios de zoopoética e biopolítica. Florianópolis: Editora UFSC, 2011, p. 15.

10 "privato [...] del valore di exemplum morale o della veste sacra e fantástico-simbolica, propria alla tradizione alegorica". BIA GINI, Enza. "La critica tematica, il tematismo e il "Bestiario", In Bestiari del Novecento (a cura di Enza Biagini e Anna Nozzoli). Roma: Bulzoni Editore, 2001, p. 15.

${ }^{11}$ MACIEL, Maria Esther. O animal escrito. Um olhar sobre a zooliteratura contemporânea. São Paulo: Lumme Editor, 2002, pp. 18-19.
} 
de Darwin, atestada pela presença de vários livros de sua autoria na biblioteca de Pirandello ${ }^{12}$, preparou o jovem escritor para a consciência da nova dimensão que o animal iria assumir no século XX. Influências não desprezíveis na formação de um escritor que iria se transformar num dos mais importantes autores contemporâneos.

Além disso, é importante notar que, segundo Walter Moretti, é determinante na narrativa siciliana dos últimos cem anos a frequência de alguns temas e formas literárias que The conferem uma singular unidade de desenvolvimento, como a tendência a instituir

uma densa rede de relações entre o mundo dos homens e o dos animais, por meio de comparações construídas na tradicional forma literária ("como") ou por autênticas identificações dos termos confrontados. Essa é uma observação que poderia adquirir uma forte relevância histórico-crítica se fosse colocada num discurso mais amplo que levasse em conta a radical recusa da narrativa manzoniana e, em geral, do início do século XIX a considerar paralelas as duas realidades, e ilustrasse tal tendência não apenas à luz dos pressupostos naturalistas, mas também no contexto mais amplo de uma crise de valores que envolve a imagem do homem e sua dignidade. ${ }^{13}$

A presença de animais na obra de Pirandello, sobretudo nas novelas, não revela apenas sua origem, mas também o comprometimento do autor com a tradição e, como afirma Elisabetta Bacchereti:

\footnotetext{
${ }^{12}$ A biblioteca de Pirandello está conservada na última casa em que ele morou em Roma - Via Antonio Bosio, 13B -, que hoje abriga o Studio di Luigi Pirandello. Istituto di Studi Pirandelliani e sul Teatro Contemporaneo. É possível consultar a relação das obras constantes na biblioteca no próprio Instituto ou no site www.studiodiluigipirandllo.it. De Darwin, constam os seguintes livros: L'origine dell'uomo e la scelta in rapporto col sesso (1871); Viaggio di un naturalista intorno al mondo (1872); Variazione degli animali e delle piante allo stato domestico (1876); I movimenti e le abitudini delle piante rampicanti (1878); I movimenti e le abitudini delle piante rampicanti (1878).

13 "una fitta rete di relazioni fra il mondo degli uomini e quello degli animali, attraverso comparazioni costruite nella tradizionale forma letteraria ("co me") o attraverso vere e proprie identificazioni dei termini confrontati. È una osservazione, questa, che acquisterebbe un forte rilievo storico-critico se venisse collocata in un discorso più ampio che tenesse conto della radicale estraneità della narrativa manzoniana $\mathrm{e}$, in genere, del primo Ottocento a una tale considerazione parallela delle due realtà, e illustrasse tale tendenza non solo alla luce dei pressuposti naturalistici ma anche nel contesto più ampio di una crisi di valori che coinvolge l'immagine dell'uo mo e la sua dignità." MORETTI, Walter. "Alcuni topoi della narrativa siciliana degli ultimi cent'anni”, In Studi e problemi di critica testuale. Vol. 3, out 1971, p. 318.
} 
o universo criativo de Pirandello, especialmente no imenso laboratório sempre aberto representado pela novelística, não se subtrai à antiquíssima tradição de alimentar a imaginação literária com figurações zoomorfas, tanto que de suas páginas espreitam, com uma frequência altamente significativa, com maior ou menor discrição, às vezes em primeiro plano, outras camuflados, protagonistas "falantes" ou inquietantes indicadores de sentido, numerosos animais. ${ }^{14}$

É também importante notar que parte da formação do autor foi o período de estudos em Bonn, onde teve oportunidade de entrar em contato com as principais ideias dos filósofos alemães (e provavelmente conheceu também as ideias de Darwin). No Taccuino di Bonn, Pirandello escreve, perguntando-se sobre o papel do artista em sua época:

Que uso se fez das teorias científicas dos filósofos modernos? Um pouco a todos influenciou Comte - exceto aos artistas. E as teorias de Darwin perfeitamente aplicáveis à arte? Palavras mortas - quero dizer as teorias sobre a seleção natural e a seleção sexual na evolução animal para melhor. Quem leu as Degenerações humanas de Sergi? Ah, nenhum artista cumpre sua obrigação e entende sua verdadeira missão no campo do progresso e da civilização. $^{15}$

Pirandello, ao cumprir aquilo que entende como sua obrigação como artista, revela compreender que o homem e os animais não pertencem a mundos distintos. Seja nas fábulas

\footnotetext{
14 “l'universo creativo di Pirandello, specialmente in quell'immenso cantiere sempre aperto rappresentato dalla novellistica, non si sottrae all'antichissima tradizione di nutrire l'immaginazione letteraria com figurazioni zoomorfe, tanto che dalle sue pagine occhieggiano, con una frequenza altamente significativa, con maggior o minor discrezione, talvolta in primo piano, talaltra defilati, protagonisti "parlanti" o inquietanti indicatori di senso, numerosi animali." BACCHERETI, Elisabetta. "L' 'animalesca filosofia'. Appunti per un 'Bestiario' pirandelliano", In I segni e la storia. Studi e testimonianze in onore di Giorgio Luti. Firenze: Casa Editrice Le Lettere, 1996, p. 162.

15 "Che uso si è fatto delle teorie scientifiche dei moderni filosofi? Un po' a tutti ha parlato il Comte - tranne agli artisti. E le teorie di Darwin applicabilissime all'arte? Parole morte - voglio dire le teorie sulla scelta naturale e sulla scelta sessuale nella evoluzione animale verso il meglio. Chi ha letto le Degenerazioni umane del Sergi? Ah nessuno degli artisti ade mpie all'obbligo suo e intende la sua vera missione nel campo del progresso e della civiltà." PIRANDELlO, Luigi. "Taccuino di Bonn". In Saggi, poesie e scritti varii. Milano: Arnoldo Mondadori Editore, 1993, p. 1227-1228.
} 
de tipo esópico, que escreveu inspirado por Gotthold Lessing ${ }^{16}$, seja nas novelas e nos romances e até mesmo no teatro, o animal frequentemente aparece com sua verdadeira face, participando da trama ou até mesmo substituindo o homem como personagem. E não apenas isso, muitos dos personagens humanos do autor carregam em seus semblantes, gestos e atitudes, características animalescas que descrevem acuradamente, sem simbolismos fáceis, suas personalidade, sentimentos e paixões. Afirma Franco Zangrilli:

A obra de Pirandello [...] é um viveiro de exemplos do emprego da similitude articulada mediante o contraste de todas as componentes e nuances da analogia que evoca, associa e coloca o indivíduo face a face com seu animal-espelho, pelo modo como os animais são assemelhados aos homens, aos seus pensamentos e às suas paixões. ${ }^{17}$

Em Pirandello, há muito mais o homem zoomorfizado do que o animal antropomorfizado. As ocorrências são muitas, mas só para dar alguns exemplos, podemos citar o padre de "Dádiva da Virgem Maria" (1899), que é comparado "na longa função de consagrar a hóstia para depois engoli-la, ao gato que primeiro brinca com o rato e depois o come"18; o professor Erminio Del Donzello de "Nené e Nini" (1912), que "retorcia o pescoço como uma cegonha", ou uma amiga de Nené, da mesma novela, que tinha "uma boca de tubarão"19; Carlino Sgro de "Tirocínio" (1905), que ao ser insultado, "estendeu as mãos, e enfiou a cabeça nos ombros como uma tartaruga e gritou:" "20; Jaco Naca de "A vingança do cão" (1933), que é comparado a "um cão estúpido que, depois de se ter deixado arrancar da

\footnotetext{
${ }^{16} \mathrm{Na}$ já citada biblioteca de Pirandello são encontradas várias obras de Lessing, entre teatro (Der junge Gelehrte; Minna von Barnhelm; Emilia Galotti; Miss Sara Sampson), crítica (Laokoon), poesia (Gedichte) e fábulas (Fabeln; Drei Bucher).

17 "L'opera di Pirandello [...] è un vivaio di esempi dell'impiego della similitudine articolata mediante il contrasto di tutte le componenti e le sfumature dell'analogia che richiama, associa e mette l'individuo faccia a faccia col suo animale-specchio, come le bestie sono accostate agli uomini, ai loro pensieri e alle loro passioni." ZANGRILLI, Franco. Il bestiario di Pirandello. Fossombrone:Metauro Edizioni, 2001, p. 18.

18 "nella lunga funzione del consacrar l'ostia per poi inghiottirs ela al gatto che prima scherza col topo e poi se lo mangia". Referência: ver Anexo B.

19 "storceva il collo come una cicogna"; "una bocca da pescecane”. Referência: ver Anexo B.

20 “protese le mani, si cacciò la testa tra le spalle come una tartaruga, e gridò:” Referência: ver Anexo B.
} 
boca uma bela coxa de carneiro, agora raivosamente quebrasse os dentes num osso abandonado por quem havia aproveitado a carne" ${ }^{21}$; a esposa e as filhas do senhor Bareggi de "Fuga" (1923), "uma galinha desorientada com duas franguinhas cacarejando atrás: corre daqui, foge de lá,22.

No âmbito da literatura italiana do final do século XIX e início do século XX, Pirandello é provavelmente o autor que mais se utilizou de animais para expressar suas ideias, mesmo levando em conta os escritos de seus contemporâneos Giovanni Verga, Luigi Capuana ou Federico De Roberto.

Talvez os autores que mais se aproximem de Pirandello, sob este aspecto, sejam Italo Svevo, com o romance A consciência de Zeno (1923) e o conto "Argo e seu dono" $(1934)^{23}$, e Franz Kafka, sobretudo no livro de contos Um médico rural $(1919)^{24}$, no qual vale destacar “O novo advogado", um cavalo advogado chamado Dr. Bucéfalo e "Um relatório para uma academia" ${ }^{25}$, único conto de Kafka em que o narrador é um animal, um macaco que atende ao convide de uma academia e faz uma palestra para relatar como, em cinco anos, conseguiu se transformar em homem. Trata-se, no entanto, de situações isoladas dentro da obra desses autores, mesmo considerando a conhecida obra de Kafka, A Metamorfose, e não constituem, como em Pirandello, uma prática constante. Com efeito, a obra de Pirandello é permeada por um vivo mundo animal, que pode não saltar aos olhos imediatamente, mas que, de certa maneira, é decisivo para a construção de sua narrativa.

Até recentemente a crítica literária havia praticamente ignorado a presença animal na literatura considerando-a, talvez apenas um expediente narrativo como tantos outros. E não

\footnotetext{
21 "un cane balordo che, dopo essersi lasciato strappar di bocca un bel cosciotto di montone, ora rabbiosamente si rompesse i denti su l'osso abbandonato da chi s'era goduta la polpa". Referência: ver Anexo B.

22 "una gallina spersa e due pollastre pigolanti dietro: corri di qua, scappa di là". Referência: ver Anexo B.

23 Ambas as obras têm como personagem o cão Argo.

${ }^{24}$ KAFKA, Franz. Um médico rural. Trad.: Modesto Carone. São Paulo: Companhia das Letras, 1999.

${ }^{25}$ Este conto, certamente humorista no sentido pirandelliano, provavelmente foi influenciado pela publicação, em 1917, de A mentalidade dos macacos, do psicólogo Wolfgang Köhler, que ao estudar os primatas de Tenerife conclui que os macacos, como os humanos, não aprendem apenas por tentativa e erro, mas pela compreensão do problema.
} 
apenas na obra de Pirandello, mas em geral na obra de outros escritores contemporâneos em que o animal é bastante frequente, como no Bestiário ou cortejo de Orfeu (1911) de Guillaume Apollinaire, em Bestie (1917) de Federigo Tozzi, em Bichos (1940) de Miguel Torga, em Bestie del '900 (1951) de Aldo Palazzeschi, no Bestiário (1951) de Julio Cortázar, em O livro dos seres imaginários (1968) de Jorge Luis Borges, ou no Bestiario (1991) de Dino Buzzati. Somente de alguns anos para cá, com o fortalecimento da consciência ambiental, começou-se a "perceber" a presença dos animais na literatura e passou-se a tentar entender essa presença não mais como um simples e corriqueiro expediente literário, mas como um necessário e desejado resgate da dignidade animal.

De forma que o objetivo deste trabalho é examinar e chamar a atenção para esse rico e pouco estudado aspecto da obra de Pirandello, pois o autor, como um agudo observador de sua época, reconhece a importância dos animais na cultura e no desenvolvimento da civilização, assim como reconhece, como veremos, os maus tratos e injustiças a que estão submetidos. Espelhos naturais dos animais humanos, capazes de sofrer e entender esse sofrimento, agentes do acaso e da impassibilidade da natureza, os animais inserem-se perfeitamente na poética do autor. E vale mais uma vez repetir com Pirandello: "diante dos olhos de um animal, desmorona como um castelo de cartas qualquer sistema filosófico" ${ }^{\text {. }}$.

\footnotetext{
26 "davanti agli occhi di una bestia crolla come un castello di carte qualunque sistema filosofico". PIRANDELLO, Luigi. "Foglietti”, In Saggi, Poesie e Scritti varii. Milano: Arnoldo Mondadori Ed itore, 1993, p. 1270.
} 


\section{Luigi Pirandello: biografia e autobiografia}

É verdade que ou vivemos ou escrevemos a vida, e que quando a vivemos dificilmente ao mesmo tempo, isto é, em meio à ação e à paixão, podemos conseguir as condições que são próprias da arte: afastar-se do momento, superá-lo para contemplá-lo e dar-lhe sentido universal e valor eterno. ${ }^{27}$

27 "È vero che la vita o si vive o si scrive e che, quando la si vive, difficilmente nello stesso tempo, cioè in mezzo all'azione e alla passione, ci si può mettere in quelle condizioni che sono proprie dell'arte: partirsi dal mo mento, superarlo per contemplarlo e dargli senso universale e valore eterno". PIRANDELLO, Luigi. "Discorso al Convegno 'Volta' sul teatro drammatico (1934)". In Saggi, poesie, scritti varii. Milano: Arnoldo Mondadori Editore, 1993, p. 1037. 
Luigi Pirandello nunca escreveu uma verdadeira autobiografia. São conhecidos apenas um fragmento de autobiografia, ditado a Pio Spezi, em 15 de agosto de 1893, e publicado na revista "Nuova Antologia", em 1933, onde o autor declara:

...Eu sou filho do Caos; e não alegoricamente, mas em justa realidade, porque nasci numa nossa casa de campo, que se localiza próxima a um intrincado bosque denominado, em forma dialetal, Càvusu pelos habitantes de Girgenti. ${ }^{28}$

E uma, assim chamada, Carta autobiográfica ${ }^{29}$, escrita por volta de 1909 ao editor da revista "Le lettere", Filippo Súrico, e publicada na mesma revista em 1924, que se resume a umas poucas frases curtas, basicamente informativas.

Há também parte do primeiro capítulo de um romance inacabado, que, pelo título, Informações sobre a minha involuntária temporada na terra (1936), e pelo fragmento remanescente, seria provavelmente uma autobiografia que o autor iniciou a escrever no ano de sua morte:

Não gosto de falar pelas costas de ninguém; e por isso, agora que prevejo próxima a minha partida, passo a dizer diante de todos as informações que darei, se acontecer de em algum lugar me perguntarem notícias dessa minha

\footnotetext{
28 “...Io dunque son figlio del Caos; e non allegoricamente, ma in giusta realtà, perché son nato in una nostra campagna, che trovasi presso ad un intricato bosco, denominato, in forma dialettale, Càvusu dagli abitanti di Girgenti." PIRANDELLO, Luigi. "Frammento d'autobiografia". In Saggi, poesie, scritti varii. Milano: Arnoldo Mondadori Editore, 1993, p. 1279.

${ }^{29}$ PIRANDELLO, Luigi. "Lettera autobiografica". Ibidem, pp. 1281-1283.
} 
involuntária temporada na Terra, onde numa noite de junho caí como um vagalume sob um grande pinheiro solitário num campo de oliveiras às margens de um altiplano de argilas azuladas, sobre o mar africano. ${ }^{30}$

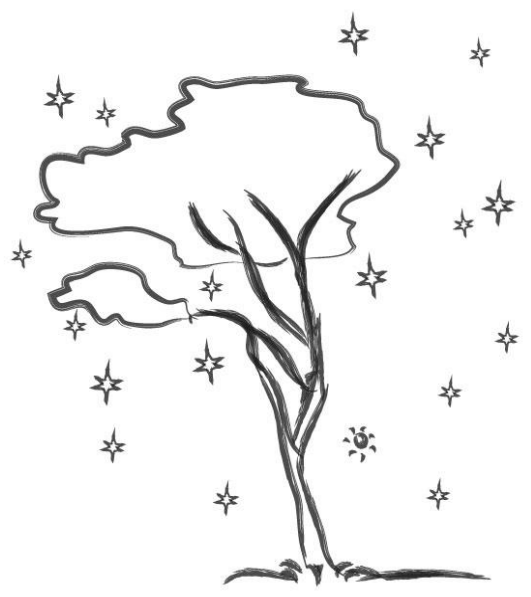

Os dois trechos citados, apesar da distância que os separam, mostram a importância, para Pirandello, de reafirmar, até poética e alegoricamente, a condição de siciliano, e siciliano nascido no campo, aonde pediu para ser levado depois da morte, em seu breve testamento - Minhas últimas vontades a serem respeitadas:

Incinerem-me. E meu corpo, em cinzas, seja espalhado; porque nada, nem mesmo as cinzas, gostaria que sobrasse de mim. Mas se isso não for possível, a urna cinerária seja levada à Sicília e murada em alguma rústica pedra nos campos de Girgenti, onde nasci. ${ }^{31}$

\footnotetext{
30 "Non mi piace parlare alle spalle di nessuno; e perciò, ora che prevedo prossima la mia partenza, mi metto a dire in faccia a tutti le informazioni che darò, se m'avverrà che altrove mi si domanderanno notizie di questo mio involontario soggiorno sulla Terra, dove una notte di giugno caddi come una lucciola sotto un gran pino solitario in una campagna d'olivi sarraceni affacciata agli orli d'un altipiano d'argille azzurre sul mare africano." PIRANDELLO, Luigi. "Informazioni sul mio involontario soggiorno sulla terra". Frag mento de 1936. Ibidem, p. 1105.

31 "Bruciatemi. E il mio corpo, appena arso, sia lasciato disperdere; perché niente, neppure la cenere, vorrei avanzasse di me. Ma se questo non si può fare sia l'urna cineraria portata in Sicilia e murata in qualche rozza pietra nella campagna di Girgenti, dove nacqui." PIRA NDELLO, Luigi. "Mie ultime volontà da rispettare". Ibidem, p. 1289.

As vicissitudes para o cumprimento das últimas vontades do autor são narradas por Roberto Alajmo no livro Le ceneri di Pirandello. Roma: Drago, 2008.
} 
Pirandello nasceu na noite de 27 para 28 de junho de 1867, em uma casa de campo da família, próxima à cidade de Agrigento - na época denominada Girgenti -, para onde sua mãe havia se transferido por causa de uma epidemia de cólera que atingira a região. Essa casa situa-se num local então denominado "u Càvusu" ou "u Càusu", na divisa entre as cidades de Agrigento e Porto Empedocle, como conta Andrea Camilleri em Biografia del figlio cambiato:

A linha de divisa entre os dois municípios, ao longo da costa, foi fixada à altura da foz de um rio seco que, há tempos imemoráveis, dividia em dois um lugar, ora chamado "u Càvusu" ora "u Càusu", tão denso de árvores que parecia um bosque.

Ora, em dialeto siciliano, tanto "càvusu" quanto "càusu" significam a mesma coisa: calças. E realmente aquele pedaço de planalto dividido deveria parecer um par de calças, para quem chegava por mar, [...] desse Càvusu, uma metade pertencia ao novo município de Porto Empedocle e a outra metade ao município de Girgenti.

Um belo dia, algum empregado do cartório de registros achou que não era coisa que se escrevesse no registro de nascimentos que um filho de camponês nascera dentro de um par de calças e mudou aquele vulgar "Càusu" para "Caos". 32

A denominação do local de nascimento, mais tarde, iria se tornar bastante útil para formar a imagem de Pirandello e de sua obra, não apenas pelo autor, mas também pelos críticos e estudiosos de sua obra.

O pai, Stefano, era garibaldino de primeira hora, havia participado das empresas de Garibaldi em 1860 e 1862, e se casado com a irmã de um companheiro de farda, Caterina

\footnotetext{
32 "La linea di confine fra i due comuni, lungo la litoranea, venne fissata all'altezza della foce di un fiume da tempo immemorabile essiccato che tagliava in due una contrada, ora chiamata "u Càvuso" ora "u Càusu", fitta tanto d'alberi da pare re un bosco. / Ora, in dialetto siciliano, tanto càvusu quanto càusu significano la stessa cosa: pantaloni. E veramente un paio di pantaloni doveva parere quel pezzo d'altopiano tagliato da chi giungeva per via di mare $[. .$.$] di questo Càvusu, una metà apparteneva al nuovo Co mune di Porto Empedocle \mathrm{e}$ l'altra metà al Comune di Girgenti. / Un bel gio rno, a qualche impiegato dell'ufficio anagrafe, parse che non era cosa scrivere sul registro delle nascite che qualque figlio di viddrani era nato dentro a un paio di pantaloni e cangiò quel volgare 'Càusu' in 'Caos'." CAMILLERI, Andrea. Biografia del figlio cambiato. Milano: RCS Libri S.p.A., 2003, pp. 15-16.
} 
Ricci Gramito. O avô materno, Giovanni, participara da revolução siciliana de 1848-1849 e morrera exilado em Malta. A família, no entanto, tinha uma boa condição financeira, uma vez que o avô paterno, Andrea, se transferira de Gênova, mais precisamente de Pra', para explorar a mineração e o comércio de enxofre, cenário que posteriormente aparecerá em muitas das novelas de Pirandello, sobretudo naquelas com temas relativos à disputa de terras ("A 'fumaça'”, 1901), à condição social do trabalhador nas minas ("Ciàula descobre a lua”, 1912) ou à própria exploração do metal (“O não de Anna”, 1895).

Isso tudo fez com que o menino Luigi, nascido durante o período de afirmação do Reino da Itália, crescesse num clima de acentuada consciência política e baixa religiosidade, mas sem dificuldades econômicas, numa então pequena, mas importante cidade comercial do interior da Sicília.

Além disso, é preciso levar em conta, na formação do autor, a tradição da Sicília. Ponto de cruzamento de várias culturas que de tempos em tempos se alternaram na dominação da ilha e acabaram por criar um ambiente cultural multiforme, amalgamando costumes, conceitos, mitos e ritos. Comenta Pasquale Tuscano:

Para entender precisamente o espírito e as raízes da percepção existencial de Pirandello, é preciso não perder de vista as condições sociais, culturais, econômicas e de costume do território agrigentino daquele tempo. De fato, terá um peso notável sobre sua índole não apenas a qualidade humana daquela Sicília grega, colonizada pelos dóricos, e, por isso, com a extraordinária herança de mitos e de ritos ocultistas e esotéricos que lá deixaram, mas também o sentimento da dor, o sentimento melancólico da decomposição da carne e da morte, que derivam de eventos trágicos, presentes e vivos no ano de seu nascimento, e dos quais muito lhe falarão, com o ar consternado de quem vê em cada fato da vida uma vontade 
superior, um sinal do destino, tanto a mãe quanto, com mais insistência, a velha doméstica Maria Stella. ${ }^{33}$

De fato, a influência siciliana em Pirandello, sobretudo aquela agrigentina pontuada pela cultura clássica, permanecerá em suas obras, mesmo naquelas que não se referem diretamente à Sicília. E, certamente, isso muito se deve ao convívio com a doméstica Maria Stella, com quem o menino burguês aprendeu não apenas fábulas, lendas e cantos populares sicilianos, envoltos em um ar esotérico e mágico, mas também rudimentos de instrução religiosa. Essa Sicília camponesa, mágica e supersticiosa, repleta de duendes, bruxas e espíritos malignos, que se misturam com os santos da religião católica, está muito presente nas obras do autor. Basta pensar, por exemplo, nas novelas "O corvo de Mìzzaro" (1902), “O estorninho e o Anjo Cento e Um” (1910), “O espírito maligno” (1910), “O Senhor dos Navegantes" (1916), ou "O filho trocado" (1902). Sobre a influência de Maria Stella, afirma Gasapare Giudice:

Pirandello desde pequeno aprendeu com ela a crer nos espíritos. Os espíritos são o que são; mas têm uma concretude inconcreta, e podem, evocados ou não, apresentar-se num momento ou outro, oportuno ou inoportuno, e se manifestar. Em resumo, estética idealista ajudando a acabar com o princípio supersticioso, são personagens em potencial... ${ }^{34}$

\footnotetext{
33 "Per cogliere puntualmente gli umori e le radici della cognizione esistenziale del Pirandello, ocorre non perdere di vista le condizioni sociali, culturali, economiche, di costume, del territorio agrigentino del tempo. Infatti, avrà un notevole peso sulla sua indole non soltanto la qualità u mana di quella Sicilia greca, colonizzata dai Dori, e, quindi, con la straordinaria eredità di miti e di riti misteriosofici ed esoterici che vi lasciarono, ma anche il sentimento del dolore, il senso accorato del disfacimento della carne e della morte, che gli deriva da eventi tragici, presenti e vivi l'anno della sua nascita, e dei quali gli parleranno a lungo, con l'aria sgomenta di chi vede in ogni fatto della vita una volontà superiore, un segno del destino, sia la madre che, con più insistenza, l'anziana domestica Maria Stella." TUSCANO. Pasquale. L'identità impossibile. L'opera di Luigi Pirandello. Napoli: Loffredo, 1989, pp. 11-12.

34 "Pirandello imparò piccino da lei a credere negli spiriti. Gli spiriti sono quello che sono; ma la loro è una concreta inconcretezza, e possono, evocati oppure no, presentarsi in un momento o nell'altro, opportuno o inopportuno, e dire la loro. Insomma, estetica idealistica aiutando a bruciare il principio superstizioso, sono personaggi in potenza..." GIUDICE, Gapare. Pirandello. Torino: UTET, 1980, p. 23.
} 
De forma que o convívio com Maria Stella e o imaginário camponês siciliano também foram decisivos para a presença, sobretudo nas novelas, de um grande número de animais, sejam eles domésticos, de terreiro, ou selvagens.

Pirandello leva para sua narrativa as marcas da Sicília natal, sejam elas culturais ou naturais, que ao longo de sua trajetória vão sendo filtradas e se atenuando ao serem somadas a outras experiências do autor. Muitas dessas marcas se traduzem justamente na utilização de animais que, conhecidos direta ou indiretamente na infância, se espalham por sua obra principalmente para dar sustentação às suas ideias. Em 1933, três anos antes de sua morte, no longo ensaio "Não falo de mim", Pirandello escreve: "Ai do escritor que a um certo ponto não se recorda da infância, onde seu mundo originalmente tem raízes, e não volta fiel ao compromisso assumido quando gritou que nascera para se exprimir., 35

No caso de Pirandello, a fixação de memórias da infância parece ter sido fundamental para o desenvolvimento de sua narrativa e para a concepção de seus personagens, sobretudo aqueles animais. Antonio Candido, referindo-se às considerações de François Mauriac sobre a maneira como um autor manipula a realidade para construir a ficção, afirma que

o grande arsenal do romancista é a memória, de onde extrai os elementos da invenção, e isto confere acentuada ambiguidade às personagens, pois elas não correspondem a pessoas vivas, mas nascem delas. Cada escritor possui as suas "fixações da memória", que preponderam nos elementos transpostos da vida. ${ }^{36}$

Além do primeiro contato com a ama, como muitas das crianças da época, Luigi recebe a primeira instrução em casa por meio de um preceptor, que depois será retratado na

\footnotetext{
35 "Guai allo scrittore che a un certo punto non si ricorda della infanzia, dove ha radici originarie il suo mondo, e non torna fedele all'impegno assunto quando gridò che era nato per esprimere. PIRANDELLO, Luigi. Non parlo di me. Como-Pavia: Ibis, 2010, p. 34.

36 CANDIDO, Antonio. "A personagem do romance", in A personagem de ficção. São Paulo: Editora Perspectiva, 2000, pp. 66-67.
} 
novela "A escolha" (1898) e no romance O falecido Mattia Pascal (1904). Em seguida, foi encaminhado à escola técnica, pois o pai pretendia iniciá-lo no comércio do enxofre. Ao mesmo tempo, escondido do pai, mas com ajuda da mãe, começou a estudar latim, inscrevendo-se, a seguir, no ginásio.

Por volta de 1880, a família transfere-se para Palermo, a capital da Sicília, devido a novas atividades profissionais do pai. Ali, o adolescente entra em contato com a cidade grande, termina seus estudos secundários e conhece a prima Lina, por quem se apaixona e de quem fica noivo, causando certo desconforto na família, por causa do parentesco. O distanciamento de Agrigento e da "desordenada biblioteca luchesiana",37 alarga os horizontes do jovem que se aventura em suas primeiras poesias, mais tarde reunidas no livro Mal Giocondo [Mal agradável] ${ }^{38}$ (1889), e também escreve sua primeira novela, "Choupana Farsa siciliana", publicada em "La Gazzetta del popolo della domenica", em 01 de junho de 1884, uma narrativa fortemente influenciada pelo máximo expoente da literatura siciliana da época, Giovanni Verga, que Pirandello nunca deixará de respeitar, mas de cujas ideias irá se afastar gradativamente, até encontrar seu próprio caminho.

No verão de 1886, Luigi volta a Agrigento para trabalhar nas minas de enxofre com o pai. No mesmo ano, inscreve-se na Faculdade de Direito, para agradar ao pai, e ao mesmo tempo na Faculdade de Letras da Universidade de Palermo. Participa da vida política e cultural da cidade, envolvendo-se com a ideologia do movimento dos "Fasci Siciliani", e escreve uma de suas primeiras peças para teatro - Gli uccelli dall'alto [Os pássaros que voam alto], hoje perdida, que oferece à Companhia Pietriboni, em fevereiro de 1887, na época em turnê pela Sicília. Nessa peça, já se prefigura a revolução que o autor iria fazer no teatro contemporâneo, como se depreende da carta por ele escrita à irmã Lina, em novembro de

\footnotetext{
37 "disordinata biblioteca luchesiana". VIRDIA, Ferdinando. Invito alla lettura di Luigi Pirandello. Milano: Mursia, 1975, p. 19. Esta biblioteca, depois, será retratada em Il fu Mattia Pascal, como a bib lioteca mun icipal de Miragno.

${ }^{38} \mathrm{O}$ título deriva de um verso de um importante autor italiano do século 15, Angelo Poliziano, e faz parte da obra Le Stanze, Canto I: Sì bel titolo d'Amore ha dato il mondo / a una peste cieca, a un mal giocondo.
} 
1886: "Imagine que no primeiro ato obrigo os espectadores do teatro a atuarem na minha peça, e transporto a ação do palco para o poço da orquestra." ${ }^{39}$ Em carta de 31 de outubro de 1886, explica à Lina a metáfora do título:

Minha Lina, você já viu os grous voarem? Esses pobres pássaros são loucos, e quase nunca pousam. Os ventos e as tempestades os atingem, mas eles vão sempre em frente, sema saber para onde. Só sabem que vão em frente. Os galos e as galinhas, os pássaros burgueses, ciscam na lama e riem dos pássaros do alto, que passam gritando, quase imprecando... O que você acha que entendam esses galos e galinhas $?^{40}$

Em abril de 1887, escreve uma peça que pensa em oferecer à companhia de Eleonora Duse e Flavio Andò, que se apresentava no teatro Bellini, em Palermo: "Escrevi, em três dias, uma Comédia popular, em sete cenas: se daqui a cinco ou seis dias, relendo-a, ainda me agradar, irei entregá-la à Duse para representação" ${ }^{41}$. A Comédia popular, depois, será intitulada Fatti che or son parole [Fatos que agora são palavras].

Sobre a produção juvenil de Pirandello, escreve Elio Gioanola:

Da produção teatral juvenil de Pirandello, não temos nada ("Queimei tudo. Nada me resta agora, exceto um vago remorso"), de modo que não podemos conhecer o conteúdo daquele drama, mesmo se o autor nos forneceu alguns indícios quando diz que já o título chama atenção para aqueles pássaros, como o grou, que voam muito alto, em contraposição com aqueles que ciscam o chão. É uma clara metáfora da figura do poeta, de ascendência baudelairiana (o albatroz de asas demasiado grandes para caminhar no solo),

\footnotetext{
39 "Figurati che nel primo atto costringo gli spettatori del teatro a far da attori nella mia commedia, e trasporto l'azione dal palcoscenico all'orchestra." PIRA NDELLO, Luigi. Lettere giovanili da Palermo e da Roma, 1886-1889. Roma: Bulzoni, 1993, p. 161.

40 "Lina mia, hai veduto le grue volare? Quei poveri uccelli son pazzi, e non posano quasi mai. I venti e le tempeste le percotono; ma loro van sempre avanti, senza saper dove. Sanno solo che vanno avanti. I galli e le galline, gli uccelli borghesi, razzolano nel fango e ridono di quelli uccelli dall'alto, che passano stridendo, quasi imprecando... Che vuoi tu che ne capiscano quei galli e quelle galline?" Ibidem, p. 148-149.

41 "Ho scritto in tre giorni u ma Commedia volgare, in sette scene: se fra cinque o sei giorni, rileggendola, mi piacerà ancora, la darò alla Duse per la rappresentazione.” Ibidem, p. 197.
} 
o "sonhador da vida" que se sente um deslocado e um iludido incapaz de se acertar com a realidade. ${ }^{42}$

Abandonando definitivamente a Faculdade de Direito, transfere-se para Faculdade de Letras da Universidade de Roma para prosseguir os estudos, mas ao defender um colega que ria por causa de um erro do professor de latim - Onorato Occioni -, também diretor da faculdade, é obrigado a abandonar o curso. Por recomendação do docente de filologia românica, Ernesto Monaci, inscreve-se na Universidade de Bonn, na Alemanha. Na época, a Universidade de Bonn era renomada na área de filologia românica e Pirandello encontra ali um clima propício para seus estudos.

Em Bonn, conhece Jenny Schulz-Lander, filha de sua locatária, uma jovem de costumes muito mais liberais do que aqueles a que ele estava habituado, e com quem tem um breve romance. A ela dedica seu segundo livro de poesias, Pasqua di Gea [Páscoa da Terra] (1891), de influência carducciana, com algumas referências a Leopardi. Nessa época, o contato com a poesia de Goethe e com o ambiente alemão, levam- no a traduzir para o italiano as Elegias Romanas e escrever dezesseis poesias que publicará em 1895, sob o título Elegias Renanas.

Sobre a temporada de Pirandello em Bonn, comenta Enzo Lauretta:

Bonn representa para Pirandello um período importante de efervescente atividade: estuda, faz amizades, está descontraído, ama; um período de intenso amadurecimento se é verdade que o período depois de Bonn é fundamentalmente diferente. Depois, Pirandello irá se casar, terá filhos, escreverá outras poesias, mas passará principalmente à narrativa e então ao teatro: por isso a temporada em Bonn não é uma pausa [...] mas uma sólida

\footnotetext{
42 "Della produzione teatrale giovanile di Pirandello non abbiamo nulla ("Ho bruciato tutto. Nulla ora mi rimane tranne un rimpianto vago") quindi non possiamo conoscere il contenuto di quel dramma, anche se qualche indizio l'autore ce l'ha fornito quando dice che già il titolo porta l'attenzione su quegli uccelli, come le gru, che volano molto in alto, messi in contrapposizioni con quelli che razzolano terra a terra. È una chiara metafora della figura del poeta, di ascendenza baudelairiana (l'albatros delle ali troppo grandi per camminare al suolo), il 'sognatore della vita' che si sente uno spostato e uno illuso incapace di venire a patti con la realtà." GIOANOLA, Elio. Pirandello's story: la vita o si vive o si scrive. Milano: Jaca Book SpA, 2007, pp. 82-83.
} 
plataforma de preparação para ter clara uma nova linha de comportamento juntamente com uma maior atenção em olhar a si mesmo, a sociedade e a literatura. $^{43}$

Essa maior atenção em olhar a sociedade e a si mesmo fica patente nas anotações que o autor faz em seu bloco de notas, hoje conhecido como Taccuino di Bonn:

Decididamente, nós, em nossas diatribes contra a sociedade moderna perdemos o ponto de vista correto. É da sociedade que recebemos os nomes de amigo, de marido, de esposa, e outros que implicam em deveres contra a natureza. Então quando, a animalidade do homem, a besta natural faz alguma das suas, nós nos voltamos contra a sociedade, como se todos os males viessem dela. ${ }^{44}$

É também nessa temporada alemã que se encontra a única menção de Pirandello à sua convivência mais assídua com um animal de estimação, no caso o cão Moppy ou Mob:

Mob (de hoje em diante chamarei sempre assim meu cão, não mais Moppy, que é palavra vazia. $M o b$ è um vocábulo inglês e quer dizer malta: fica bem para um cão; nós dizemos o mesmo a algum grande homem que ele representa a humanidade) - Mob [...] ereto sobre duas patas olhou-me ler todo o tempo em silêncio, apenas sacudindo as orelhas e arrastando a cauda no chão como uma cobrinha toda vez que eu tirava os olhos do livro para respirar mais fundo com dificuldade. ${ }^{45}$

\footnotetext{
${ }^{43}$ Bonn rappresenta per Pirandello un periodo importante di fervente attività: studia, fa amicizia, è disteso, ama; un periodo d'intensa maturazione, se è vero che il dopo Bonn è fondamentalmente diverso. Dopo Pirandello si sposerà, avrà dei figli, scriverà altre poesie, ma pas serà soprattutto alla narrativa e poi al teatro: perciò quella di Bonn non è una pausa [...] ma una solida piattaforma di preparazione per aver chiara una linea di comportamento nuova assieme ad una maggiore attenzione nel guardare se stesso, la società, la letteratura. LAURETTA, Enzo. Luigi Pirandello. Storia di un personaggio "fuori di chiave”, Milano: Mursia, 1950, p. 220.

${ }^{44}$ Decisamente noi nelle nostre diatribe contro la società moderna abbiamo perduto il giusto punto di vista. È dalla società che noi abbiamo i no mi di amico, di marito, di moglie, e simili che implicano dei doveri, contro la natura. Or bene l'animalità dell'uomo, la bestia naturale ne fa qualcuna delle sue - noi ce la prendiamo con la società, come se tutti i danni venis sero da lei. PIRANDELLO, Luigi. "Gita a Kessenib" - "Taccuino di Bonn", In Saggi, Poesie, Scritti varii. Milano: Arnoldo Mondadori Editore, 1960, p. 1234.

${ }^{45}$ Mob (da oggi in poi chiamerò sempre cosi il mio cane, non piú Moppy, che è parola vuota. Mob è vocabolo inglese e vuol dire canaglia: sta bene a un cane; noi diciamo similmente a qualche grand'uomo che egli rappresenta l'umanità) — Mob [...] diritto su due zampe mi ha guardato leggere tutto il tempo in silenzio, scuotendo solo le orecchie e strisciando per terra la coda come una serpetta ogni qual volta io levavo gli occhi
} 
A menção ao cão Mob aparece também em uma carta escrita aos pais, em fevereiro de 1891, na qual Pirandello mostra sua preocupação para com o animal quando de seu próximo retorno à Itália: “O que me preocupa é o meu belo, bom e fiel Mob. Devo levá-lo comigo?"46

No final de 1891, Pirandello conclui seus estudos em Bonn com a tese sobre fonética e morfologia siciliana, Laute und Lautenwickelung der Mundart von Girgenti ${ }^{47}$, elogiada pelo respeitável filólogo suíço Wilhelm Meyer-Lübke.

Depois de completado os estudos, Pirandello passa um breve período como leitor em Bonn, volta para Agrigento, onde rompe definitivamente o noivado com Lina e se transfere para Roma, ainda às expensas do pai, para se dedicar à vida literária e à carreira de escritor, abandonando definitivamente as pretensões acadêmicas e a filologia - que "arruína o estômago e encolhe o cérebro". ${ }^{48}$

Começa então a frequentar o ambiente literário da capital, onde conhece seu conterrâneo Ugo Fleres, poeta, jornalista e crítico, que o apresenta a outros sicilianos radicados em Roma e ligados à escola verista, como Giuseppe Mantica, Giovanni Alfredo Cesario, Giuseppe Aurelio Costanzo, Nino Martoglio, Ugo Ojetti e, entre eles, Luigi Capuana. Capuana, já reconhecido romancista, estimula Pirandello a se dedicar à narrativa, o que leva o autor a escrever seu primeiro romance, inicialmente chamado Marta Ajala, que é publicado em 1901 com o título A excluída. Na Carta autobiográfica, afirma Pirandello:

Até o final de 1892 não me parecia possível que eu pudesse escrever mais do que versos. Devo a Luigi Capuana o incentivo para tentar a arte narrativa em

dal libro per trar piú lungamente il respiro non tanto facile. PIRANDELLO, Luigi. "Gita a Kessenib" "Taccuino di Bonn", Ibidem, p. 1231.

46 “Quel che mi dà a pensare è il mio bello, buono e fedele Mob. Devo portarlo con me?” PIRA NDELLO, Luigi. Lettere da Bonn: 1889-1891. Roma: Bulzoni, 1984, p. 179.

${ }^{47}$ PIRANDELLO, Luigi. "Fonetica e sviluppo fonico del dialetto di Girgenti", Ibidem, pp. 7-54.

48 "guasta lo stomaco e rimpiccio lisce il cervello". Carta à irmã Lina (Rosalina), datada de 13 de janeiro de 1891. Cfr. GIOVANA RDI, Daniela. I lettori d'italiano in Germania. Tübingen, Gunter Narr Verlag, 1996, p. 46. 
prosa (e digo arte narrativa em prosa, porque até pouco tempo tinha na gaveta o manuscrito de uma longa narração em versos, um poema sobre o príncipe dos demônios Belfagor, também composto antes que eu partisse para a Alemanha, e também humorista). ${ }^{49}$

Em 1894, casa-se com Maria Antonietta Portolano, filha de um sócio de seu pai. O casamento garante ao casal um dote substancial integralmente aplicado nas minas de enxofre do pai e do sogro, o que permite aos Pirandello estabelecer-se definitivamente em Roma, até com alguma folga financeira. No mesmo ano, Pirandello publica seu primeiro livro de novelas, Amores sem amor.

O início da produção novelística pirandelliana pode ser considerado a partir da publicação deste livro. Há somente duas novelas do autor publicadas anteriormente ("Choupana" e "A rica" na revista "Tavola Rotonda", em novembro de 1892), o que ainda não caracteriza uma produção constante. Assim, é a partir de 1894, com a publicação de sete novelas em jornais e revistas e deste livro, que reunia três delas ${ }^{50}$, que o autor passa a escrever e publicar narrativa curta com certa regularidade.

As novelas, gênero a que Pirandello se dedicará pelo resto de sua vida, eram publicadas principalmente em revistas literárias, como "Nuova Antologia" e "Marzocco", nas quais o escritor colaborava também com artigos, ensaios e crítica de teatro, em jornais, como o "Corriere della Sera". No entanto, nesse primeiro momento, seu interesse ainda está voltado para a poesia, a narrativa ficava em segundo plano, sendo considerada uma atividade quase diletante, tanto é que ele cedia suas novelas para publicação sem receber por elas qualquer compensação monetária, diferentemente de quase todos os outros escritores da época.

\footnotetext{
49 "Fino a tutto il 1892 non mi pareva possibile che io potessi scrivere altrimenti, che in versi. Devo a Luigi Capuana la spinta a provarmi nell'arte narrativa in prosa (e dico arte narrativa in prosa, perché fino a poco tempo fa avevo nel cassetto il manoscritto di una lunga narrazione in versi, un poema su l'arcid iavolo Belfagor, composto anch'esso prima che partissi per la Germania, e anch'esso umoristico)." PIRANDELLO, Luigi. "Lettera autobiografica". In Saggi, Poesie, Scritti varii. Milano: Arnoldo Mondadori Editore, 1960, pp. 12861287.

50 "A onda", "A senhorita" e "A amiga das esposas".
} 
Com o nascimento dos filhos, Stefano (1895), Lietta (1897) e Fausto (1899), e as constantes dificuldades financeiras de seu pai na direção das minas de enxofre, que provia o sustento de toda a família, Pirandello foi praticamente obrigado a aceitar, em 1897, o cargo de professor de Linguística e Estilística no "Istituto Superiore di Magistero di Roma”, em substituição a Giuseppe Mantica, cargo esse que irá ocupar por mais de vinte anos.

Em 1898, juntamente com Carlo Falbo e Ugo Fleres, funda a revista semanal "Ariel”, que terá 25 edições até o ano seguinte. Sobre a proposta do grupo fundador da revista, que inclú́a Luigi Capuana e outros sicilianos, diz Romano Luperini:

De fato, tratou-se de um núcleo de resistência que, ao mesmo tempo em que constatava a crise do positivismo e do naturalismo e gradualmente afastavase destas posições, também não pretendia aderir às novas, fossem elas o simbolismo, o irracionalismo decadente ou, mais tarde, os grupos juvenis florentinos ou o nascente neoidealismo representado por Benedetto Croce. ${ }^{51}$

Na verdade, o início do novo século trouxe uma série de incertezas que culminaram com a falência do positivismo, sobretudo depois da Interpretação dos sonhos, de Sigmund Freud, de 1899 (mas publicada com data de 1900) e de A teoria da relatividade (1905), de Albert Einstein. Assim sendo, para o grupo fundador de "Ariel”, não era mais possível manter-se no caminho aberto por Verga, com seu verismo, mas também não era possível aderir às vanguardas que a todo instante procuravam explorar o que depois iria se revelar como um beco sem saída.

No período que vai até 1902, Pirandello continua escrevendo novelas para jornais e revistas, mas ainda escreve poesia, publicando o livro Zampogna [Gaita de foles] em 1901, e seu segundo romance $O$ turno, ambos os livros com pouca expressão junto ao público. $\mathrm{O}$

\footnotetext{
51 "Di fatto, si trattò di un nucleo di resistenza che, mentre prendeva atto della crisi del positivis mo e del naturalismo e gradualmente si allontanava da tali posizioni, non intendeva peraltro aderire alle nuove, fossero esse quelle del simbolismo e dell'irrazionalis mo decadenti o, più tardi, dei gruppi giovanili fiorentini o del nascente neo-idealismo rappresentato da Benedetto Croce.” LUPERINI, Romano; Pirandello. Roma-Bari, Editori Laterza, 2005, pp. 11-12.
} 
autor parece se dedicar mais à carreira de literato interessado em poesia do que de escritor. A produção de novelas seria, para ele:

um tipo de ginástica de base, de exercício cotidiano [...]. A partir do momento em que Capuana o persuade à prosa até o momento do final do exercício, isto é, até a data de sua morte, Pirandello produz novelas quase por uma espécie de coação espontânea, como tecidos biológicos que se reproduzem incessantemente. ${ }^{52}$

Em 1903, um acidente provoca o alagamento da mina de enxofre de Aragona, na qual estava empregado o dote de Maria Antonietta, e que garantia uma pensão mensal para o sustento dos Pirandello em Roma. Isso provoca um pesado desequilíbrio econômico na família e graves distúrbios nervosos em Antonietta que, recolhida ao leito com grave paralisia psíquica, nunca irá se recuperar.

Pela necessidade de complementar o salário de professor, Pirandello empenha as joias da esposa, pede retribuição a jornais e revistas pelas novelas e artigos já publicados, faz traduções, dá lições particulares de italiano e de alemão. Nesse período, apesar dessas vicissitudes, começa a escrever o romance O falecido Mattia Pascal, que publicará em 1904 e The dará reconhecimento nacional e projeção internacional.

A partir de então, a produção de novelas passa a ter mais regularidade e, depois de publicadas em jornais e revistas, estas são reunidas em livros. Assim, entre 1902 e 1919 são publicados os livros: Zombarias da vida e da morte e Quando eu era louco... (1902); Brancas e negras e Herma bifronte (1904); A vida nua (1910); Tercetos (1912); As duas máscaras (1914); A armadilha e Erva de nossa horta (1915); E amanhã, segunda-feira... (1917); Um cavalo na lua (1918); Berecche e a guerra e O carnaval dos mortos (1919). Muitas dessas

\footnotetext{
52 "una specie di ginnastica di base, di esercizio quotidiano [...]. Dal momento in cui Capuana lo persuade alla prosa fino al mo mento della chiusura d'esercizio, cioè alla data di morte, Pirandello produce novelle, quasi per una sorta di coazione spontanea, come i tessuti biologici riproducono incessan temente le loro." BARILLI, Renato. "Pirandello e la rivoluzione culturale dei nostri tempi". In Luigi Pirandello. Ro ma: Istituto Poligrafico e Zecca dello Stato, 1995, p. XV.
} 
novelas têm sua origem na intensa colaboração de Pirandello para com o periódico milanês “Corriere della Sera”, um dos mais respeitáveis jornais do país na época. Iniciadas em 4 de outubro de 1909, com a novela "Mundo de papel”, as publicações só irão se encerrar em 9 de dezembro de 1936, na véspera da morte do autor, com a novela "Efeitos de um sonho interrompido". Sobre as novelas que o autor envia ao periódico, comenta Sarah Zappulla Muscarà:

O escritor, desde as primeiras nove las que entrega ao jornal lombardo, tem o cuidado de alternar a uma [novela] "cômica e camponesa" - $O$ jarro - uma "triste sim, mas conclusa" - A luz da outra casa -, a uma "humorista" - Não é uma coisa séria - "uma trágica e no entanto ridícula" - O pássaro empalhado -,variando, assim, ora [novelas] "urbanas", ora "campestres". Ora "alegres", ora "tristes", mas sempre com "alguma gentileza e suavidade de poesia", conclui, "esperamos contentar um pouco todos os leitores do Corriere". ${ }^{53}$

Mais do que a publicação de livros, era importante contar com a divulgação do trabalho de um autor em veículos de grande circulação. Nos jornais, os assuntos de cultura (novelas, romances de folhetim, críticas literárias, etc.), como era costume na época, ocupavam as terceiras páginas ${ }^{54}$, geralmente diagramadas em duas colunas e impressas com um caractere tipográfico conhecido como elzeviro, termo que depois passou a denominar conteúdo da publicação. A publicação de um autor nesta página garantia certa notoriedade e, em jornais de grande circulação, um público bastante amplo, além de uma renda imediata.

\footnotetext{
53 "Lo scrittore sin dalle prime novelle che affida al foglio lombardo ha cura di alternare ad una 'comica e paisana' - La giara - una 'triste sì ma conclusa' - Il lume dell'altra casa -, ad una 'umoristica' - Non è una cosa seria - 'una tragica e pur ridicola' - L'uccello impagliato -, così, variando, ora 'cittadine' ora 'campestri'. Ora 'gaje' ora 'tristi', ma sempre con 'qualche gentilezza e soavità di poesia', conclude, 'speria mo di contentare un po' tutti i lettori del Corriere"”. MUSCARÀ, Sarah Zappulla. "In margine ad una novella sconosciuta dell'ultimo Pirandello". In Le novelle di Pirandello. Atti del $6^{\circ}$ Convegno Internazionale di Studi Pirandelliani Raccolti e Ordinati da Stefano Milioto. Agrigento, Edizioni del Centro di Studi Pirandelliani, 1980, p. 193.

${ }^{54}$ Os jornais italianos na época tinham quatro páginas: na primeira publicava-se o artigo de fundo e as principais notícias do dia, na segunda as notícias de política e na quarta as notícias secundárias e a publicidade. Excepcionalmente, no domingo, o jornal saia com seis páginas.
} 
Em 1908, para a nomeação de professor efetivo, Pirandello publica seus principais ensaios: O humorismo e Arte e Ciência. O humorismo pode ser considerado sua declaração de poética, ou seja, a linha mestra de seu pensamento em relação à literatura e ao papel do literato no início do século 20. Com este ensaio, ele se afasta, pelo menos em tese, de sua ligação com o Verismo de Verga e passa a desenvolver uma poética própria, distanciada também das vanguardas do início do século. O "humorismo" pirandelliano pressupõe uma decomposição efetuada pela reflexão, num movimento que leva o observador dos fatos para além do acontecimento externo - "percepção do contrário" - em direção à compreensão do acontecimento em si - "sentimento do contrário" - por meio de um deslocamento de perspectiva que não é necessariamente cômico. Esse efeito pode ou não ficar evidente para o leitor, mas certamente acarretará nele um estranhamento que também o levará à reflexão. A publicação do ensaio sobre o humorismo causou imediata reação de Benedetto Croce que acusou Pirandello de "cerebralismo abstrato" e de tentar misturar arte e filosofia, conceitos não compatíveis segundo a estética crociana, que considera a arte como pura intuição. Essa crítica abriu uma longa polêmica com ataques de ambos os lados.

Apesar de toda a teoria do humorismo e de $O$ falecido Mattia Pascal ser decididamente um romance humorista, o romance seguinte, de 1909, Os velhos e os moços, ainda trilha bem de perto os caminhos do Verismo. De ambientação siciliana, passa-se durante os movimentos revolucionários de 1893, conhecidos como "Fasci Siciliani", uma luta de classes de inspiração democrática e socialista, que envolve o proletariado urbano, trabalhadores agrícolas, mineiros e operários.

Finalmente, o antigo sonho do autor começa a se realizar. Em dezembro de 1910, aos 43 anos, Pirandello leva aos palcos de Roma, dois "atos únicos", ou seja, peças teatrais curtas que se resumiam a apenas um ato. Essas peças correspondiam, grosso modo, às narrativas 
curtas e eram representadas aos pares ou aos trios. Neste dia, foram representadas as peças Limões da Sicília (adaptada da novela homônima) e $O$ torniquete.

A partir daí, a atividade teatral passa a ocupar cada vez mais o escritor e, juntamente com a produção de novelas para o jornal "Corriere della Sera", traz o tão esperado reconhecimento como intelectual, também garantindo ao autor alguma independência financeira.

Assim, no período entre 1911 e 1917, muitas das peças levadas à cena são adaptações diretas de novelas escritas e publicadas anteriormente. Porém, com a representação da "parábola em três atos" Assim é (se lhes parece), em junho de 1917, e a posterior publicação em janeiro de 1918 da novela "A senhora Frola e o senhor Ponza, seu genro" 55 , ambas com o mesmo argumento, Pirandello começa a escrever peças nem sempre extraídas diretamente das novelas, às vezes combinando ideias de mais de uma novela ou criando um enredo totalmente original.

O sucesso como dramaturgo faz com que Pirandello deixe a cátedra e passe a se dedicar quase que exclusivamente ao teatro. Esse sucesso leva o autor a publicar suas peças, a partir de 1918, reunidas em livros sob o título geral de Máscaras Nuas.

Mesmo com a intensa atividade teatral desse período e com a Primeira Guerra Mundial (1914-1918), Pirandello continua escrevendo narrativa e publica, além de várias novelas, os romances $O$ marido dela [Suo marito] (1911), que depois terá seu título alterado para Giustino Roncella nascido Boggiòlo [Giustino Roncella nato Boggiòlo], na versão de 1941, e Ação...[Si gira...] (1915), cujo título também será alterado para Cadernos de Serafino Gubbio operador [Quaderni di Serafino Gubbio operatore].

O ano de 1921 foi decisivo para a afirmação de Pirandello como dramaturgo. Em 9 de maio, estreou no Teatro Valle de Roma a primeira peça da trilogia que depois seria conhecida

\footnotetext{
${ }^{55}$ É difícil determinar a data em que cada novela ou peça foi escrita, u ma vez que Pirandello costumava escrever simultaneamente várias novelas e peças, de forma que se deve considerar a data de publicação das novelas ou de primeira representação das peças como referência para sua composição.
} 
como "teatro no teatro": Seis personagens em busca de autor. ${ }^{56}$ Apesar do grande fracasso inicial quando foi recebida na estreia, aos gritos de "Manicômio! Manicômio!" e obrigada a ser retirada de cartaz, a peça, após uma reestreia consagrada em Milão ${ }^{57}$, teve larga carreira internacional e revolucionou a maneira de se fazer e ver teatro.

Seguindo o exemplo da reunião de peças teatrais, Pirandello inicia o projeto Novelas para um ano, em 1922. Contando, nesse momento, com mais de duzentas novelas publicadas, o autor resolve reuni-las em volumes com quinze novelas cada, de modo a formarem, num conjunto de 24 volumes, um total de 365 novelas para serem lidas, uma a uma a cada dia do ano. A organização dos volumes, no entanto, não segue a ordem cronológica da publicação precedente, nem leva em conta temas ou outro tipo de relação entre as novelas inseridas num mesmo volume. Sobre a organização do projeto Novelas para um ano, afirma Giovanni Macchia:

Certamente, ao reordenar todo o patrimônio novelístico, revisto também na língua, Pirandello pretendia atribuir caráter de atemporalidade a sua mensagem literária e sugerir sua fruição sincrônica, convencido das raízes ontológicas da condição humana da qual os personagens são imutáveis "espelhos". 58

Apesar de a crítica ter consagrado na obra de Pirandello a imagem do "espelho", talvez uma representação mais apropriada ao conjunto das novelas, assim organizadas, seria a de um grande edifício que dispõe de tantas janelas abertas quantas são as novelas, cada uma delas focalizando um pequeno fragmento da vida, de maneira a formar um grande e torturante afresco. Restariam, porém, algumas janelas fechadas; estas seriam as novelas que faltaram

\footnotetext{
${ }_{57}^{56}$ As outras duas peças são: Cada um a seu modo (1924) e Esta noite se improvisa (1929).

5727 de setembro de 1921.

58 “Certo, nel riordinare tutto il patrimonio novellistico, rivisto anche nella lingua, Pirandello intendeva attribuire carattere di atemporalità al suo messaggio letterario e suggerirne una fruizione sincronica, convinto del radicamento ontologico della condizione umana di cui i personaggi sono immutabili 'specchi'." MACCHIA, Giovanni. "Prefazione". In PIRANDELLO, Luigi. Novelle per un anno. Milano: Mondadori, 1957.
} 
para completar o projeto. A fruição sincrônica das novelas é certamente um dos objetivos do autor, que na apresentação (avvertenza) do primeiro volume, em 1922, avisa:

Apresso-me em advertir que as novelas desses vinte e quatro volumes não pretendem ser singularmente nem das estações, nem dos meses, nem de qualquer um dos dias do ano. Uma novela ao dia por um ano inteiro, sem que dos dias, dos meses ou das estações nenhuma tenha retirado sua qualidade. $^{59}$

Essa série de negações é também um trajeto de leitura instituído pelo autor, na medida em que a fragmentação da realidade faz com que o leitor se depare com uma espécie de espiral do tempo, em que cada ano se renova no seguinte, numa repetição infinita, permitindo ao leitor sempre novas leituras e reflexões. Giovanni Macchia ainda salienta que a provável "não" organização das novelas apresenta um aspecto emblemático que pode genericamente ter a dimensão de cosmo, mas um cosmo que está prestes a se tornar caos:

Lendo estas novelas uma após outra, não se percebem etapas possíveis pelas quais o caos, o caos pirandelliano, transforme-se em cosmo, mas apenas representações aparentes de um falso cosmo que quase irremediavelmente recomece a ser caos. ${ }^{60}$

Mas se o caos não pode se tornar cosmo, talvez a organização das novelas, mesmo não intencionalmente, possa ser associada à definição de "fractal", em que o todo forma a parte e a parte forma o todo.

\footnotetext{
59 "Mi affretto a avvertire che le novelle di questi ventiquattro volumi non vogliono essere singolarmente né delle stagioni, né dei mesi, né di ciascun giorno dell'anno. Una novella al giorno per tutt'un anno, senza che dai giorn i, dai mesi o dalle stagioni nessuna abbia tratta la sua qualità." Apud LUPERINI, Ro mano. Pirandello. Roma-Bari: Editori Laterza, 2005, p. 138.

60 "Leggendo queste novelle l'una dietro l'altra non s'intravedono tappe possibili per cui il caos, il caos pirandelliano, diventi cosmo, ma soltanto figurazioni apparenti di un falso cosmo che quasi ineluttabilmente ricominci ad essere caos." MACCHIA, Giovanni. "Premessa". In Novelle per un anno. Vol. I, Tomo 1. Milano: Arnoldo Mondadori Editore, 1985, p. XVIII.
} 
Talvez, ainda, tenha sido a forma como Pirandello pretendeu demonstrar seu afastamento do verismo, pois como afirma Gino Tellini

Quando a aproximação ao real (tanto o externo como o da consciência) torna-se investigação do cotidiano, é exatamente nesse momento que se capta o ponto de ruptura que perturba, como um calafrio, o passar dos dias: infração e ultraje ao código das certezas progressivas que o final do século se obstina a glorificar. ${ }^{61}$

No entanto, para efeitos deste estudo, é preciso adotar uma linha diacrônica de publicação (na falta de dados exatos relativos ao ano de composição) para recuperar o desenvolvimento dos elementos formais e de conteúdo de alguma forma ocultos nessa labiríntica coletânea. As novelas diacronicamente dispostas conforme a data da primeira publicação ${ }^{62}$, mais do que outras obras, permitem recompor, não apenas alguns fatos biográficos do autor, mas o desenvolvimento gradativo de uma poética marcada pelas incertezas do homem que ao entrar em um novo século repleto de contradições e mudanças, ainda guarda a lembrança de um tempo onde as certezas eram absolutas e irrefutáveis.

Assim, é possível identificar, percorrendo as novelas, uma evolução na obra de Pirandello que vai desde uma primeira fase em que ele entra em contato com o mundo que o cerca e parte em busca de uma explicação para a angústia do homem do século nascente, passando pelo cuidadoso mapeamento da realidade, que tem como fulcro o relacionamento humano, até chegar à constatação de que uma possível solução seria a reintegração desse homem à natureza. ${ }^{63}$

\footnotetext{
61 "Quando l'appressamento al reale (quello di fuori come quello della coscienza) diventa indagine sulla quotidianità, proprio allora si coglie il punto di rottura che scompiglia, come un brivido, lo scorrere dei giorni: infrazione e oltraggio al codice di quelle certezze progressive che il secolo declinante si ostina a osannare." TELLINI, Gino. Il romanzo italiano dell'ottocento enovecento. Milano: Bruno Mondadori, 1998, p.128.

${ }^{62}$ Ver quadro no anexo A.

${ }^{63}$ Para um exame mais aprofundado permito-me remeter ao meu livro, Pirandello "novellaro": da forma à dissolução. São Paulo: Nova Alexandria-Humanitas, 2009.
} 
O percurso evolutivo da obra narrativa de Pirandello, que se pode identificar nas novelas, foi um tanto obscurecido pela obra teatral do autor, que ao se deter no personagem, sobretudo naquele personagem que pode ser levado à cena, teve outros elementos deixados de lado pela crítica. O tremendo sucesso de suas peças fez com que a crítica se preocupasse mais com o que via no teatro, onde o personagem humano ocupa o papel central, do que com sua obra em prosa, na qual coabitam personagens humanos e não humanos. Principalmente depois da análise da obra dramatúrgica de Pirandello feita por Adriano Tilgher, em 1928, em que este formulou o dualismo vida e forma.

A antítese é, por isso, a lei fundamental dessa arte. A inversão das comuns, ordinárias, habituais re lações da vida triunfa soberana. [ ... ] Dualismo da Vida e da Forma ou Construção; necessidade da Vida de se identificar numa Forma e impossibilidade de se exaurir nela: este é o motivo fundamental que subjaz em toda a obra de Pirandello e lhe dá uma sólida unidade e organicidade de visão. ${ }^{64}$

Esta análise marcou definitivamente a obra de Pirandello, sobretudo em relação ao personagem, não permitindo, por vezes, vê-la de uma maneira mais ampla. Insere-se aqui o foco exclusivo dado por Tilgher ao personagem humano, quando a obra de Pirandello, principalmente as novelas, é povoada por animais que, para além da vida e da forma, também atuam como contraponto ao humano. Nesses animais "a vida triunfa soberana" e leva a uma reconciliação com a natureza que é, em síntese, a mensagem final de Pirandello, ou seja, é a "realidade outra", a "dissolução", presente nas últimas novelas do autor.

O que se percebe, percorrendo diacronicamente as novelas, é que Pirandello, muitas vezes, confia aos animais um papel que vai além da simples contextualização de uma

\footnotetext{
64 “L'antitesi è perciò la legge fondamentale di quest'arte. L'inversione dei comuni ordinarii abituali rapporti della vita trionfa sovrana. [ ... ] Dualismo della Vita e della Forma o Costruzione; necessità per la Vita di calarsi in una Forma ed impossibilità di esaurirvisi: ecco il motivo fondamentale che sottostà a tutta l'opera di Pirandello e le dà una ferrea unità e organicità di visione." TILGHER, Adriano. Studi sul teatro contemporaneo. Roma: Libraria di Scienze e Lettere, 1928, p. 132.
} 
paisagem ou em função de elementos complementares ao entrecho. Algumas vezes eles são os protagonistas da narrativa e comparecem inclusive no título de 18 delas ${ }^{65}$.

Olhando para os animais presentes nas novelas é até mesmo possível perceber as fases da narrativa de Pirandello no tipo e no papel dos animais representados.

Assim, nas primeiras novelas e num período que vai aproximadamente até 1902 , em que o autor descreve e analisa seu contato com o mundo, a frequência de animais é pequena, em geral com o aparecimento de animais ligados à Sicília rural, mais destinados a dar um sabor local à narrativa, ou como metáfora e descrição de aspectos físicos ou psicológicos dos personagens. É também a fase em que Pirandello se dedica às fábulas de modelo esopiano, com as quais ele procura entender as relações entre os homens de modo a traçar um painel dos relacionamentos humanos de fim de século. Quase coagido espontaneamente a escrever novelas, segundo Barilli, Pirandello traz na sua narrativa as marcas da Sicília natal, que muitas vezes se traduzem justamente na utilização de animais. Em Il romanzo italiano dell'ottocento e novecento, Gino Tellini afirma:

Na Itália apenas unida, longe de se assistir a um processo homogêneo de energias convergentes, se observa, ao contrário, um fenômeno geral de angústia da exclusão: erguem-se forças adormecidas e latentes, mobilizadas pelo legítimo desejo de tutelar a sobrevivência de tradições locais, antropológicas, culturais, linguísticas, de alguma maneira sacrificadas ao sonho da pátria una e independente. Não é de causar espanto que, diante dos inúmeros problemas reais de um país que se esforça em se estudar, se conhecer ou se engrandecer, para assumir, seja como for, uma identidade moderna, seja exatamente o romance, como instrumento de conhecimento e de polêmica, o gênero de vanguarda que conquista proeminência nacional. Nem causa espanto que, por esse caminho, a glór ia caiba a autores e teóricos

\footnotetext{
65 “Os galetos do barqueiro" (1894), “Outra cotovia" (1902), "O corvo de Mìzzaro" (1902), “A mosca” (1904), "A fidelidade do cão" (1904), "Bo linha e Mimi" (1905), "Um cavalo na lua" (1907), "O pássaro empalhado" (1910), "O estorninho e o anjo Cento e Um" (1910), "Andorinho e Andorinha" (1913), "O cabrito negro" (1913), "O gato, um pintassilgo e as estrelas" (1917), “O morcego" (1920), "As muretas, uma figueira, um passarinho" (1931), “A vingança do cão" (1933), "Sorte de ser cavalo" (1935), "Vitória das formigas" (1936), “A tartaruga" (1936).
} 
meridiona is (De Sanctis, Capuana, Verga, De Roberto, Pirandello). Neles, a fidelidade à terra de origem é indubitavelmente sólida, mas pede para ser decantada e polida por experiências culturais amadurecidas alhures, nas regiões do Norte. Consolida-se então, e se torna habitual, o itinerário de ida e volta, de Mineo, Catânia, Nápoles, Agrigento, para Roma, Florença, Milão (ou Bonn), que continuará a manter, também em nosso século, seu emblemático significado de viagem da consciência. ${ }^{66}$

Com a intensificação da produção de novelas, tendo já assumido o papel de "novellaro" ${ }^{67}$, também se intensifica a representação de animais nas novelas. Trata-se do período romano do autor, em que a Sicília natal já ficou distante e ele anseia pelo reconhecimento como intelectual na cidade grande e talvez no mundo. É o período da narrativa humorista e da concepção do humorismo como linha mestra para explorar e tentar entender, como afirma Luperini, "o sentimento da vacuidade e da insensatez da vida, a percepção de um estranhamento ou distonia em relação ao mundo, a ênfase do caráter ilusório e compensativo dos valores e dos ideais humanos" ${ }^{68}$. Entram em cena, nas novelas, os animais domésticos, mais ligados à vida das cidades, como cães, gatos, pássaros e cavalos, e aparecem

\footnotetext{
66 "Nell'Italia appena fatta, lungi dall'assistere a un processo omogeneo di energie convergenti, si osserva invece un generale fenomeno di angoscia dell'esclusione: si destano forze sopite e latenti, mobilitate dal legittimo desiderio di tutelare la sopravvivenza di tradizioni locali, antropologiche, culturali, linguistiche, comunque sacrificate al sogno della Patria una e indipendente. Non stupisce allora che, dinanzi agli innumerevoli problemi reali di un paese che s'affanna laboriosamente a studiarsi, a conoscersi o nobilitarsi, per assumere come che sia un'identità moderna, sia proprio il romanzo, in quanto strumento di conoscenza e di polemica, il genere d'avanguardia che conquista preminenza nazionale. Né stupisce che su questa strada la palma spetti a autori e teorici meridionali (De Sanctis, Capuana, Verga, De Roberto, Pirandello). In essi la fedeltà alla terra d'origine resta indubitabilmente salda, ma chiede però di essere decantata e illimpidita da esperienze culturali maturate altrove, nelle reg ioni del Nord. Si consolida ora, e diviene abituale, quell'it inerario di andata e ritorno, da Mineo, Catania, Napoli, Agrigento, verso Roma, Firenze, Milano (o Bonn), che continuerà a mantenere anche nel nostro secolo il suo emb lematico significato di viaggio della coscienza." TELLINI, Gino. Il romanzo italiano dell'ottocento e novecento. Milano: Bruno Mondadori, 1998, p.120-121.

67 "Desde que comecei a escrever novelas, tornei-me 'novellaro' de profissão (como diriam em Roma) e ninguém mais se lembra que comecei como poeta, e se procuro um editor para publicar um livro de versos, ouço a resposta: 'Se for um livro de novelas sim; versos não: os versos não vendem!' [Da quando mi son messo a scriver novelle, son diventato di professione 'novellaro' (come direbbero a Ro ma) e nessuno pensa più che cominciai da poeta e se per poco mi rivolgo a un editore per avere stampato un libro di versi, mi sento rispondere: 'Se per un libro di novelle, sì; versi, no: i versi non vanno!']. In PUPO, Ivan. Interviste a Pirandello: "Parole da dire, uomo, agli altri uomini". Soveria Mannelli: Rubbettino Editore, 2002, p. 107.

${ }^{68}$ il sentimento della vanità e dell'insensatezza della vita, la percezione di una estraneità o distonia rispetto al mondo, la sottolineatura del carattere illusorio e compensativo dei valori e degli ideali umani. LUPERINI, Romano. Pirandello. Roma-Bari: Laterza Editori, 2005, p. 3.
} 
os primeiros animais protagonistas como, por exemplo, "Bolinha e Mimi" na novela homônima. Esses animais também fazem parte de sua busca pela explicação do sofrimento humano, da necessidade do homem de se ver viver e se sentir uno, servindo como contraponto e até como exemplo de uma vida que se insere sem culpa no "fluxo contínuo" da existência.

Às vésperas da organização das Novelas para um ano, a produção novelística de Pirandello é quase nula, ele provavelmente sabe que será praticamente impossível, nos anos que lhe restam, cumprir a tarefa de escrever mais de 150 novelas para completar o projeto. Além disso, depois da publicação de seu último romance, Um, nenhum e cem mil, em $1926^{69}$, há uma espécie de pausa na produção do escritor em que ele parece estar vislumbrando uma saída, uma "nova realidade" em que a vida, destruída pela impossibilidade de se construir uma identidade, renova-se na natureza, fazendo ressurgir a fantasia, as ilusões, os instintos e os mitos contra as forças negativas e destruidoras.

Ao retomar a produção novelística, em 1931, esta "realidade outra" leva Pirandello a se aproximar cada vez mais da natureza, fazendo com que o personagem se dissolva nessa mãe que agora lhe parece benévola e capaz de afastar todos os males. Estão ainda mais distantes os tempos da Sicília clássica e das minas de enxofre, essa natureza benévola não encontra lugar no espaço-tempo, mas pode, e deve, ser resgatada dentro de cada ser humano. A "percepção do contrário" e o "sentimento do contrário", teorizados no ensaio O humorismo, não concorrem mais para a divisão da psique, e sim para criar um momento de extrema lucidez no qual o personagem toma consciência da sua verdadeira vida interior. Muitos críticos consideram esta uma fase "surrealista", marcada por situações narrativas que vão além da realidade sem, contudo, alterá-la radicalmente. Aqui, os animais, como representantes dessa natureza, ganham novos contornos, não são mais os animais rurais da primeira fase, nem os animais citadinos da segunda, mas animais capazes de interagir com o ser humano de

\footnotetext{
${ }^{69}$ Romance este gestado por mais de doze anos.
} 
igual para igual, como o urso que põe à prova dois missionários ("A prova") ou as formigas que se vingam por terem sido perturbadas em sua natureza ("Vitória das formigas").

As novelas são, talvez, a melhor fonte de análise de toda a obra pirandelliana, uma vez que, diacrônica ou sincronicamente, formam um conjunto de narrativas que percorrem toda a vida do escritor e representam um exercício de escrita que ele jamais abandonou, servindo como repositório de suas ideias e reflexões sobre a vida e suas vicissitudes.

Os 13 primeiros volumes das Novelas por um ano saíram pela editora Bemporad entre 1922 e 1928 e cada um deles recebeu o título da primeira novela do volume: Xale negro, A vida nua, A pirueta e O homem só (1922); A mosca e Em silêncio (1923); Todas as três (1924); Do nariz ao céu e Dona Mimma (1925); O velho Deus (1926); O jarro, A viagem, Candelora (1928). Em 1934, saiu o décimo quarto volume, Berecche e a guerra, e postumamente, em 1937, o volume Uma jornada, ambos pela editora Mondadori, que havia comprado os direitos da obra. Em 1938 foi publicado mais um volume, também póstumo, que recebeu o título de Apêndice, no qual foram reunidas as novelas que o autor não havia incluído em volumes anteriores.

Já o teatro, com o sucesso e as ousadias de Seis personagens em busca de autor, em 1921, é a maior ocupação de Pirandello. O público demanda cada vez mais suas obras, e o reconhecimento internacional não tarda a chegar. Da simples adaptação de suas novelas, o autor passa a temas originais, e cria um teatro totalmente seu, às vezes voltado para a investigação da criação teatral (o teatro no teatro), mas sempre em busca da explicação para o sofrimento da existência humana.

Também no teatro é possível identificar as fases dessa busca do autor. Assim como a solução que ele parece ter encontrado em sua fase final. Trata-se das três peças dedicadas aos 
$\operatorname{mitos}^{70}$, em que o retorno à natureza é representado pela utilização de temas como a família, a fé e a arte.

Cada vez mais empenhado com o teatro, com o cinema, que de início criticou, e com as viagens internacionais, Pirandello não tem tempo para as novelas, mas a ideia de completar as Novelas para um ano está sempre presente, como se pode verificar pela carta escrita ao diretor do "Corriere della Sera", Aldo Borrelli:

Envio-lhe, recém chegado de Nova Iorque, esta novela, e prometo que recomeçarei regularmente minha colaboração, pois é minha firme intenção terminar as minhas Novelas para umano. ${ }^{71}$

Essa firme intenção, no entanto, vem acompanhada de uma necessidade de libertação da imagem que os críticos e o público fazem de sua obra, como transparece no prefácio que Pirandello escreveu para The Drama of Luigi Pirandello, de Domenico Vittorini, em 1935:

Entre os tantos Pirandello que há algum tempo andam por aí, na crítica literária internacional, capengas, deformes, todos cabeça e nada coração, esquisitos, insolentes, lunáticos e obscuros, nos quais eu, por mais que me esforce, não consigo me reconhecer nem mesmo num mínimo traço (creio que o mais imbecil seja aquele de Benedetto Croce), o senhor também quis acrescentar mais um, todo seu, não pelo gosto de me desfigurar e depois me mostrar claudicante; não pelo gosto de me apresentar mascarado com uma cabeça de elefante e com o coração atrofiado mediante aquela bomba filtrante que é a maquininha infernal da lógica; eu atarantado entre nuvens ou soturno nas grutas; mas completamente ao contrário; e disto, como é natural e como o senhor pode bem imaginar, eu the sou muito grato, caro Vittorini. Muito grato porque, entre tantos que acreditam saber muito bem aquilo que são, eu que realmente não o sei e sempre evitei sabê-lo como por uma arbitrariedade de toda a vida que se move continuamente dentro de

\footnotetext{
${ }^{70}$ A nova colônia (1926), Lázaro (1929) e Os gigantes da montanha (1936)

71 "Vi mando, appena tornato da New York, questa novella, e Vi prometto che riprenderò regolarmente la mia collaborazione perché è ferma mia intenzione compiere le mie Novelle per un anno." PIRANDELLO, Luigi. Carteggi inediti: con Ojetti, Albertini, Orvieto, Novaro, De Gubernatis, De Filippo. Sarah Zappulla Muscarà (org.). Roma: Bulzoni, 1980, p. 241.
} 
mim, encontro no senhor alguém que me faz andar ereto sobre as pernas e me dá tanto coração quanto necessito para amar e me compadecer dessa pobre humanidade, seja quando racioc ina ou quando não raciocina; alguém que tenta explicar que se muitos acreditam que eu seja esquisito é porque me movo à minha maneira e não como os outros gostariam; insolente, porque desdenho a cortesia deles; incompreensível porque ainda não sabem ver, pensar e sentir como eu.

Mesmo assim, caro Vittorini, capenga, deforme, todo cabeça e nada coração, esquisito, insolente, lunático e obscuro, eu existo e seguirei a existir, e eles não. É verdade que isso não é algo que tenha muita importância para mim. Homem, desejei dizer aos homens algumas coisas, sem qualquer ambição, exceto talvez a de me vingar de ter nascido. Mas mesmo a vida, também por tudo o que me fez sofrer, é muito bela! (E esta é outra afirmação sem nenhuma sombra de lógica, entretanto muito verdadeira e sincera. $)^{72}$

A necessária liberdade de expressão a que Pirandello almeja é a rebelião contra as "máscaras" impostas a ele pela sociedade, que o autor, como humano, também precisou usar. Ao admitir as ideias de Tilgher, por exemplo, pode-se dizer que Pirandello teria caído numa "armadilha", que talvez ele mesmo contribuiu para construir.

\footnotetext{
72 "Tra i tanti Pirandello che vanno in giro da un pezzo nel mondo della critica letteraria internazionale, zoppi, deformi, tutti testa e niente cuore, strampalati sgarbati lunatici e tenebroni, nei quali io, per quanto mi sforzi, non riesco a riconoscermi neppure per un minimo tratto (il più imbecille di tutti credo che sia quello di Benedetto Croce), ha voluto anche lei metterne su uno, tutto suo, non per il gusto di storpiarmi e poi mostrarmi zoppicante; non per il gusto di presentarmi mascherato da una testa d'elefante e col cuore atrofizzato med iante quella po mpa a filtro che è la macchinetta infernale della logica; io annaspante tra le nuvole o intenebrato nelle grotte; ma anzi tutt'al contrario; e di questo, come è naturale e come può bene immaginarsi, io le sono molto grato, caro Vittorini. Molto grato perché, tra tanti che credono di saper molto bene ciò che sono, io che non lo so affatto e ho sempre rifuggito dal saperlo come da una soperchieria a tutta la vita che mi si muove dentro di continuo, trovo in lei uno che mi fa andar dritto sulle gambe e mi da tanto cuore quanto me n'abbisogna per amare e compatire questa povera umanità, sia quando ragiona e sia quando sragiona; uno che cerca di spiegare che se tanti mi credono strampalato è perché mi muovo a mio modo e non co me gli altri vorrebbero; sgarbato, perché ho sdegno delle loro garbatezze; incomprensibile, perché non sanno ancora vedere e pensare e sentire come me. / Co munque, caro Vittorini, zoppo, deforme, tutto testa e niente cuore, strampalato sgarbato lunatico e tenebrone, io esisto e seguiterò ad esistere, e loro no. È vero che questa non è una cosa che abbia per me molta importanza. Uomo, ho voluto dire agli uo mini qualche cosa, senz'alcuna a mbizione, tranne forse quella di vendicarmi dell'esser nato. Ma pure la vita, anche per tutto quello che m'ha fatto soffrire, è cosi bella! (Ed ecco un'altra affermazione senza nemmeno un'ombra di logica, ma tuttavia così vera e sentita.)." PIRANDELLO, Luigi. "Prefazione a The Drama of Luigi Pirandello". In Saggi e interventi. Milano: A rnoldo Mondadori Editore, 2006, pp. 1514-1515.
} 
Em nome de toda minha obra, assim com essa obra é em seu conjunto, eu me rebelo contra a minha fama e contra o pirandellismo e até chego a declarar estar pronto a renunciar ao meu nome, para reconquistar a liberdade de minha imaginação de escritor, liberdade que gozei plenamente até o momento em que escrevi minhas obras e que quero continuar a gozar até o fim, isto é, até quando minha fantasia me ofertar sua última imagem e meu cérebro sua última ideia. ${ }^{73}$

Esse sentimento de rebelião no final da vida corresponde ao momento de epifania de muitos de seus personagens, que ao fazerem o balanço de sua vida, descobrem o quanto deixaram de ser eles mesmos, o quanto se negaram uma identidade individual, cedendo ao "fluxo da vida" para não se deixar cristalizar em uma forma.

Os "tantos Pirandellos" que andam por aí buscam, nesse momento, uma nova realidade que possa integrá-los à natureza, aos mitos, à simplicidade dos animais, que em suas últimas novelas assumem um papel mais relevante em relação aos humanos, indicando uma possível saída desta escura selva cognitivo-existencial em que o homem contemporâneo encontra-se inapelavelmente perdido.

O Pirandello personagem de si mesmo, que em sua trajetória perscrutou o mundo e partiu em busca de uma explicação, agora quer se desfazer das máscaras que ele mesmo criou, quer ser uno e se dissolver na natureza, como Vitangelo Moscarda e outras de suas criaturas. É o que demonstra em suas últimas vontades: “Incinerem-me. E meu corpo, em cinzas, seja espalhado". 74

\footnotetext{
73 “A nome della mia opera tutta intera, così come questa opera è nel suo assegno, io mi ribello contro la mia fama e contro il pirandellismo e arrivo fino a dichiarare di essere pronto a rinunciare al mio nome, pur di riacquistare la libertà della mia immaginazione di scrittore, libertà di cui ho pienamente goduto fino al mo mento in cui ho scritto le mie opere e di cui voglio continuare a godere sino alla fine e cioè sino a quando la mia fantasia mi offrirà la sua ultima immagine e il mio cervello la sua ultima idea." PIRANDELLO, Luigi. “Abbasso il pirandellismo", In Saggi e interventi. Milano: Arnoldo Mondadori Editore, 2006, p. 1460.

74 "Bruciatemi. E il mio corpo, appena arso, sia las ciato disperdere." PIRANDELLO, Luigi. "Mie ultime volontà da rispettare”. In Saggi, poesie, scritti varii. Milano: Arnoldo Mondadori Editore, 1993, p. 1289.
} 


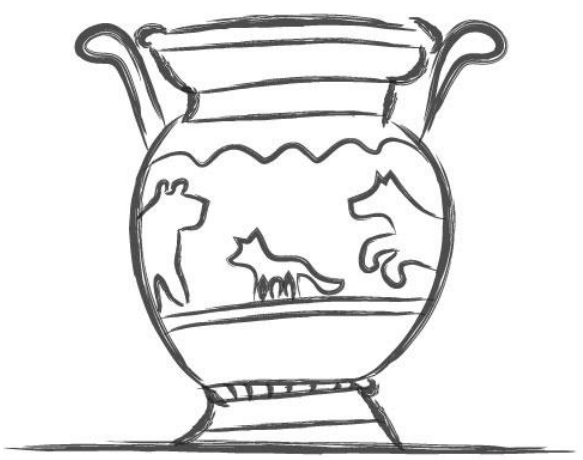

Pirandello morre de pneumonia em 10 de dezembro de 1936, aos 69 anos, mas sua obra, sua busca pela verdadeira alma humana, persiste como um alerta à humanidade de que é preciso uma integração total com a natureza. Um ambientalista avant la lettre? 


\section{A lição de Esopo}

Disse o asno para Esopo:

- Se você escrever alguma outra estorinha sobre mim, veja se me faz dizer alguma coisa razoável e sensata.

- Você, alguma coisa de sensato - respondeu Esopo; - e como isso poderia ser? Não iriam dizer que o moralista é você e o asno eu ${ }^{75}$

75 “Disse l'asino ad Esopo: / - Se tu metti fuori qualche altra storiella su me, vedi di farmi dire qualcosa di ragionevole e sennato. I - Qualcosa di sennato a te - rispose Esopo; - e come potrebbe ciò accordarsi? Non si direbbe allora che il mora lista sei tu e l'asino io?" PIRANDELLO, Luigi. Saggi, poesie e scritti varii. Milano: Mondadori, 1993, pp. 1045-1046. Tradução feita por Pirandello de u ma fábula de Gotthold Ephraim Lessing (1729-1781) publicada orig inalmente na revista "Cenerentola. Giornale pei fanciulli", Roma, anno I, n. 13, 12 de março de 1893. 
Proveniente de um mundo rural, a Sicília do século XIX, Pirandello não apenas teve contato direto com os animais de sua terra, como também com as superstições e crenças ligados a eles. Certamente de grande influência foi a criada da casa dos Pirandello, Maria Stella, que o introduziu às tradições orais sicilianas e lhe deu a primeira instrução, como conta Guglielminetti:

Luigi teria recebido a primeira instrução forte, apesar de elementar, de Maria Stella, empregada da casa, que não ignorava o patrimônio folclórico siciliano e as tradições populares. ${ }^{76}$

Outra influência importante para o autor foi a presença da civilização grega na Sicília, sobretudo na região de Agrigento, onde ele nasceu e se criou, e onde se localiza o esplêndido Vale dos Templos, hoje zona arqueológica compreendendo sete templos (Hefesto, Castor e Pólux, Zeus Olímpico, Theron, Hércules, Juno e Concórdia), tumbas, oliveiras centenárias e os gigantescos Télamons que sustentavam o Templo de Zeus Olímpico, citado por Pirandello, por exemplo, na novela "O cabrito negro" (1913).

[...] da cidade alta sobre a colina às ruínas dos Templos agrigentinos, aéreos e majestosos sobre o escarpado talude que suaviza o declive da colina

\footnotetext{
76 "Luigi avrebbe ricevuto la prima istruzione forte, se pur elementare, da Maria Stella, la domestica di casa non ignara del patrimonio folclorico siciliano e delle tradizioni popolari." GUGLIELMINETTI, Marziano. Pirandello. Roma: Salerno Editrice, 2006, p. 20.
} 
vizinha, a colina akrea, sobre a qual surgiu antigamente, faustosa de mármores, a antiga cidade exaltada por Píndaro como a mais bela das cidades mortais. $^{77}$

Por toda obra de Pirandello é possível encontrar traços de seu interesse pela Grécia, mas é sobretudo nas Novelas para um ano, que a presença desse mundo antigo, também cercado de superstições e lendas, e muito ligado à terra, assume uma característica orgânica ou, como afirma Zangrilli, vai muito além da representação dos lugares gregos da paisagem agrigentina, assumindo aspectos mais complexos do que "uma representação detalhada e obsessiva que não serve como digressão ou como simples evocação nostálgica da paisagem natal, mas está sempre ligada ao tema da narrativa". ${ }^{78}$

Essa influência do mundo clássico e a identificação de Pirandello com a Grécia, mais especificamente a Magna Grécia, pode ser verificada numa entrevista concedida à revista literária grega, "Nea Estatia", em 1934:

A Grécia está dentro de mim. Seu espírito ilumina meu pensamento e consola minha alma. Sem nunca tê-la visto, a conheço. Sou da Sicília, isto é, da Magna Grécia, e na Sicília ainda sobrevive muito de grego. Sobrevivem sua dimensão, harmonia e ritmo. Por outro lado, eu mesmo sou de origem grega. Não se espantem, meu sobrenome é Pyragghelos. Pirandello é apenas uma corruptela fonética. ${ }^{79}$

\footnotetext{
77 “"....] dalla città alta sul co lle alle rovine dei Temp li akragantini, aerei e maestosi su l'aspro ciglione che arresta il declivo della collina accanto, la collina akrea, su cui sorse un tempo, fastosa di marmi, l'antica cittá da Pindaro esaltata come bellissima tra le città mortali." PIRANDELLO, Luigi. "Il capretto nero". Referência: ver Anexo B.

78 "una rappresentazione dettagliata ed ossessiva che non serve da digressione o da semplice rievocazione nostalgica del paesaggio natale ma è sempre connessa al tema del racconto." ZANGRILLI, Franco. Pirandello e i classici. Da Euripide a Verga. Firenze: Cadmo, 1995, pp. 29-30.

79 "La Grecia è dentro di me. Il suo spirito illumina il mio pensiero e consola il mio animo. Senza averla mai vista, la conosco. Sono della Sicilia, cioè della Magna Grecia e in Sicilia molto di greco ancora sopravvive. Ne sopravvivono la misura, l'armonia, il ritmo. D'altra parte io stesso sono di orig ine greca. Certo, non vi meravigliate, il mio cognome è Pyragghelos. Pirandello non ne è che la corruzione fonetica." Cfr. ZANGRILLI, Franco. Ibidem, p. 21. Pyragghelos, em grego, seria "mensageiro de fogo", segundo o próprio Pirandello numa entrevista dada em Estocolmo e relatada por Enzo Lauretta em Pirandello umano $e$ irreligioso, Milano: Gastaldi, 1954, p. 13.
} 
Pirandello também se refere frequentemente à literatura grega e seus expoentes em vários ensaios, mas é na primeira parte de $O$ humorismo, ao analisar a obra de Aristófanes, do qual já traduzira uma parte de As rãs para o italiano, que o autor cita diretamente a fábula de tipo esopiano, ao relacionar os animais presentes na obra dos dois escritores:

Algumas de suas comédias são como as fábulas que escreveria a raposa, em resposta às que escreveram os homens caluniando os animais. Nelas, os homens raciocinam e agem com a lógica dos animais, ao passo que nas fábulas os animais raciocinam e agem com a lógica dos homens. ${ }^{80}$

As fábulas de Esopo são pequenas narrativas de natureza moral que sugerem normas de conduta através da ação de animais. Esses animais, antropomorfizados, representam, cada um a seu modo, as virtudes e os vícios humanos. Em geral, com escopo educativo, as fábulas faziam parte da tradição oral dos gregos e foram reunidas pela primeira vez por Demétrio de Falero, em 325 a.C., que as atribuiu a Esopo (séc. VI a. C.). Sabe-se pouco sobre Esopo, porém a larga difusão de suas fábulas acabou marcando alguns animais como representantes de um comportamento nem sempre verdadeiro no reino animal: a formiga trabalhadeira, a raposa esperta, a tartaruga sábia, e assim por diante. Assim, quando Pirandello se refere às "fábulas que escreveria a raposa" inverte uma ótica milenar, apesar de manter o status de sapiência conferido por Esopo a este animal. Da mesma forma, invertendo uma correlação pré-concebida entre os animais e os vícios e virtudes humanos, o autor busca mostrar "as co isas 'verdadeiras' que acontecem e voltam a acontecer no tempo e no espaço, diversamente daqueles gêneros que narram o que acontece uma só vez na História". ${ }^{11}$

\footnotetext{
80 "Alcune sue commedie son come le favole che scriverebbe la volpe, in risposta a quelle che hanno scritto gli uomini calunniando le bestie. Gli uomini in esse ragionano e agiscono con la logica delle bestie, mentre nelle favole le bestie ragionano e agiscono con la logica degli uomini." PIRANDELLO, Luigi. Saggi, poesie e scritti varii. Milano: Mondadori, 1993, p. 41.

81 "le cose 'vere' che accadono e riaccadono nel tempo e nello spazio, diversamente da quei generi che narrano ciò che succede una volta nella Storia." ZANGRILLI, Franco. "Pirandello e la favola". In Pirandello. Presenza varia e perenne. Pesaro: Metauro Edizioni, 2007, p. 38.
} 
Essa inversão de ótica é quase uma constante quando Pirandello utiliza, em suas novelas, romances ou ensaios, a fábula de tipo esopiano, muitas vezes já reelaborada pela leitura de Fedro, Ovídio ou La Fontaine.

O interesse do autor pela fábula, principalmente de origem greco-siciliana, está bastante bem documentado em seus escritos críticos, nos quais fica claro que a presença de animais no espaço narrativo, como protagonistas ou coadjuvantes, muitas vezes assume

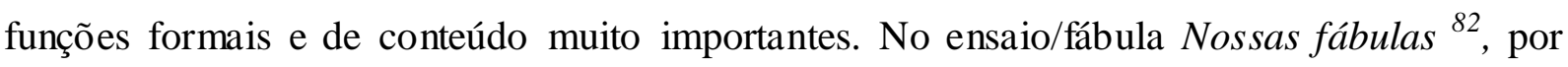
exemplo, o autor escreve:

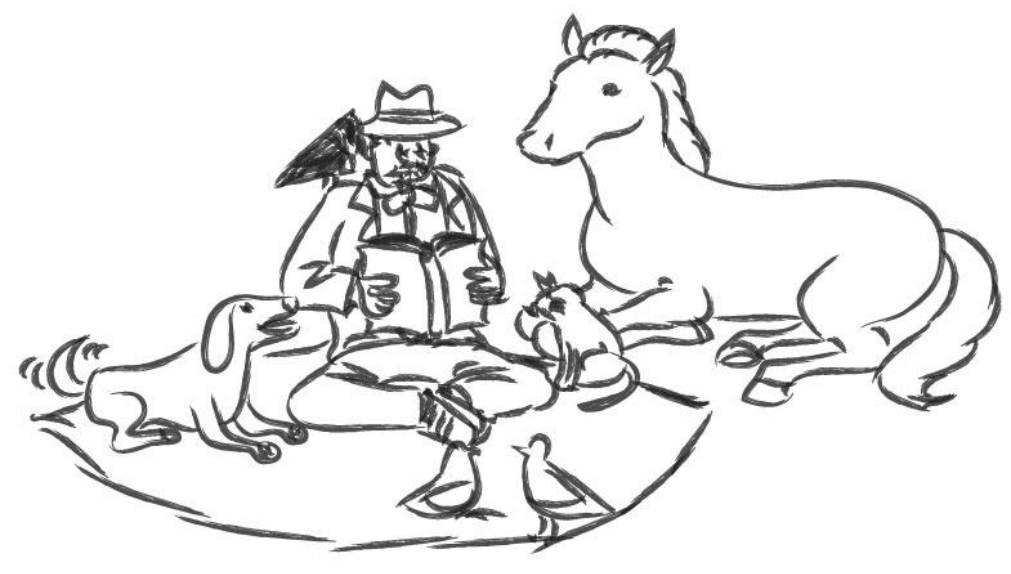

Ontem entrei no estábulo, no pátio de minha casa, e tive vontade de ler, para um belíssimo baio de notável inteligência, primeiro, algumas fábulas de Fedro e depois outras tantas de La Fontaine.

Enquanto lia, também entraram no estábulo, para ouvir, o corvo do porteiro, que tem as asas cortadas e uma sineta no pescoço, um cão vira-lata, um gato e dois pombos.

Pois bem, vocês não irão acreditar quais e quantos sinais de hilaridade deram aqueles animais à minha leitura. Garanto-lhes que eles me deram claramente a entender que todas as fábulas inventadas pelos homens, de Esopo em diante, não são mais do que ameníssimas calúnias e graciosas tolices.

\footnotetext{
${ }^{82}$ PIRANDELLO, Luigi. “Le nostre favole”. In Saggi, poesie e scritti varii. Milano: Mondadori, 1973, p. 1051. Publicado originalmente em "Il Ventesimo", Genova, 8 de abril de 1906.
} 
Um leão, uma vez, por ter fome comeu um velho negro perdido no deserto, adoentado, praticamente reduzido a pele e ossos. Comeu inteiro sem ao menos tostá-lo um pouquinho. Pouco depois, por trás de uma tenda escutou a conversa de dois exploradores que, sem vontade, sem nem terem fome, tinham matado um jovem camelo que há alguns meses os servia humilde e paciente; dividiram-no em pedaços, cozinharam-no e depois jogaram fora a carne, dizendo:

- Não está bem cozida!

Quem pode tirar da cabeça do leão, meus senhores, que a qualificação de animal feroz atribuída a ele pelos homens não signifique animal ingênuo, animal estúpido e principalmente ignorante de cozinha $?^{83}$

A inversão de perspectiva, um humano lendo fábulas para animais que se sentem caluniados, ao sublinhar a estupidez humana, reflete o aforismo 224, de Nietzsche, em $A$ gaia ciência (1882): "Receio que os animais tomem o homem por um ser como eles, mas que, por infelicidade, perdeu seu bom senso de animal - receio que eles o considerem como um animal absurdo, como o animal que ri e chora, como o animal nefasto ${ }^{84}$ " e demostra uma nítida influência da atenta leitura que Pirandello fez das fábulas de Gotthold Lessing ${ }^{85}$, sobre as quais preparou uma monografia intitulada A fábula e as fábulas, durante seu doutorado em Bonn.

\footnotetext{
${ }^{83}$ PIRANDELLO, Luigi. "Foglietti”, in Saggi, Poesie e Scritti varii. Milano: Arnoldo Mondadori Editore, 1993, p. 1051-1052. Ver texto original no final do capítulo.

${ }^{84}$ NIETZSCHE, Friedrich. A gaia ciência. Trad: Antonio Carlos Braga. São Paulo: Editora Escala, 2008, p. 180.

${ }^{85}$ Lessing (1729-1781) é considerado um dos fundadores da moderna literatura alemã. Suas fábulas estão reunidas em três livros: Fabeln und Erzählungen [Fábulas e contos], Fabeln. Drei Bücher [Fábulas. Três livros] e Fabeln [Fábulas].
} 
a) As fábulas de Messer Renardo.

O estudo de Lessing feito durante o doutorado na Alemanha, levou Pirandello a projetar um livro de fábulas, nunca completado, que se intitularia As fábulas de Messer Renardo ${ }^{86}$ ou As fábulas da raposa, cujos protagonistas seriam a raposa e outros animais, como noticia G. Federico Pipitone, ao final de um ensaio crítico sobre o livro de poesias Mal Giocondo, publicado na revista "Psiche", de Palermo, em 15 de maio de 1890:

Em breve o nosso Luigi, diplomado em filologia românica em Bonn, publicará [...] um livro de prosa, As fábulas de Renardo - trabalho de requintado bom gosto, que lhe veio à mente ao traduzir as fábulas de Lessing ${ }^{87}$ para uma monografia sobre o tema de Lessing, A fábula e as fábulas. $^{88}$

Porém, logo o "nosso Luigi" desistiu do projeto, publicando apenas as duas fábulas reportadas abaixo na "Rivista di Roma", em 10 de dezembro de 1905 e antes em "Psiche", em 16 de outubro de 1896. Essas fábulas, escritas em forma de diálogo, recuperam a tradição da filosofia e do teatro gregos, e podem ser creditadas a uma fase pós-verista, ou pré-humorista, em que o autor ainda se dividia entre a vontade de ser dramaturgo e uma presumida tendência para a poesia.

\footnotetext{
${ }^{86}$ Messer Renardo (a raposa) é o personagem principal do Roman de Renart, ciclo narrativo medieval composto em octossílabos e escrito em língua d'oil, contemporâneo aos fabliaux, e arquétipo da tradição literária animalista.

${ }^{87}$ Algumas das fábulas de Lessing, traduzidas por Pirandello, foram publicadas na revista "Cenerentola", em março de 1893: "O cavalo e o touro", "Os cães", "Esopo e o asno" e "O carvalho e o porco". Hoje em Saggi, poesie e scritti varii. Milano: Mondadori, 1973, pp. 1045-1046.

${ }^{88}$ "Tra breve il Luigi nostro, conseguito in Bonn la laurea in filologia romanza, pubblicherà [...] un libro di prosa, Le favole di Renardo - lavoro di squisita finezza, venutogli in mente nel tradurre le favole di Lessing ${ }^{88}$ per la memoria dottorale sul tema Lessing, La Favola e le Favole." PIRANDELLO, Luigi. Saggi, poesie e scritti varii. Milano: Mondadori, 1973, p. 1046, nota 1.
} 
Nelas, a avaliação do comportamento humano em relação ao comportamento dos animais é manifestamente negativa. No prólogo, ele desmonta a representação dos vícios e virtudes humanos simbolizados pelos animais e sai em busca de uma resposta que provavelmente seria dada pela raposa, representando todos os outros bichos. Ou seja, a "sábia" raposa de Esopo seria a porta-voz dos animais em resposta às calúnias que estes receberam repetidamente por séculos.

Os animais se expressam e dialogam como humanos; no entanto, refletem dentro de capacidades e características próprias, subvertendo o antropocentrismo que, transferindo para os animais os vícios e as virtudes humanas, era a base da fábula tradicional e dos muitos bestiários éticos da tradição medieval. Esse ponto de vista talvez tenha sido herdado de Lessing, mas certamente está muito ligado à tentativa do autor siciliano de entender o mundo que o rodeia. São reflexões sobre a inconsistência e infelicidade da vida, mediadas pela observação do comportamento animal.

\section{As fábulas da raposa}

Há algum tempo comecei a suspeitar que aqui e ali nas fábulas mais engenhosas de certos moralistas estivesse a patinha da raposa. Mas depois, refletindo melhor e pouco a pouco relendo quase todas as fábulas que até nossos dias, em prosa e em versos, são repetidas, concluí:

- Não! Eu calunio a raposa.

E apenas a primeira suspeita me havia passado, logo uma outra, não sei como, caiu-me na alma: que deviam existir em algum lugar fábulas originais da raposa, isto é, de Messer Renardo, como alguns moralistas a chamaram. Comecei então a procurar ansiosamente, apesar de não ter qualquer indício: busquei, remexi em grutas e em tocas, pelos campos, nas frestas e cavernas das rochas, nos buracos dos troncos de árvores centenárias, mas infelizmente sem qualquer resultado. Passaram-se muitos anos, durante os quais eu, às minhas expensas, tristissimamente aprendi a conhecer de modo bem diferente os homens e a vida; e não pensava mais em resgatar as supostas fábulas da raposa, quando de repente, numa manhã, aconteceu-me de 
descobrir a toca, onde Messer Renardo havia depositado suas tão procuradas fábulas.

Essa toca estava exatamente dentro de mim. Eu nunca teria suspeitado. Estava em meu cérebro, assim como os homens com suas inimizades e a sorte com sua adversidade haviam-no reduzido.

Agora estou contente de poder mostrar aqui duas dessas novíssimas fábulas, ambas em forma de diálogo. Quanto às outras, espero, virão à luz, quando seu autor não mais a vir.

\section{Primeira fábula}

Personagens do diálogo: Eu Renardo; Um vizinho meu

VIZINHO - Então é verdade, Messer Renardo, a notícia de que entre nós, bichos livres senhores do mundo...

RENARDO - Fale baixo, caro vizinho.

VIZINHO - Por que está rindo, Messer Renardo?

RENARDO - Estou rindo? Não; penso que isso de liberdade e de ser dono do mundo deve certamente ser uma doença comum a todos os que habitam e nasceram na terra. Há pouco tempo, antes que o senhor viesse, me divertia escutando dois passarinhos, que ali naquela árvore diziam que o ar e todo o céu eram feitos para eles, e que são seus senhores absolutos. E o mesmo, de um lado a outro, dizem os homens ao redor da terra. Mas os homens também dizem e fazem tantas outras coisas, que nem os pássaros, nenhum outro bicho já pensou em dizer ou fazer.

VIZINHO - Como assim, Messer Renardo? O senhor negaria...

RENARDO - Nunca nego nada, caro vizinho. Sempre digo que o senhor tem razão, mas que, me desculpe, eu penso de outro modo. Basta. Continuando, qual notícia foi divulgada entre vocês bichos livres (eu me considero seu mais humilde servidor) senhores do mundo?

VIZINHO - Que o senhor pretende compor fábulas em resposta à todas aquelas que há muito tempo os homens estão fazendo contra nós.

RENARDO - É verdade, meu amigo! Não contra os homens, mas contra os bichos, se tanto, mas com a finalidade - fique claro! - de corrigir seus defeitos.

VIZINHO - Grande coisa, Messer Moralista! Ah, então o senhor também se juntou com aqueles vis animais, que por encanto se deixaram domesticar 
pelos homens e agora, junto com eles, nos declaram guerra? Muito bem! Muito bem!

RENARDO - Não há de que, caro vizinho. O senhor então acredita que os homens em suas fábulas tenham falado mal de nós? Nem por sonho! Fizeram-nos pensar com a cabeça deles, colocaram em nossas bocas as suas doutas palavras, mas para retratar somente as suas tolices e seus vícios. $\mathrm{O}$ senhor quer um exemplo? Se um fabulista faz um asno falar como um homem tolo, tolo é o asno, caro vizinho? Asno é o homem!

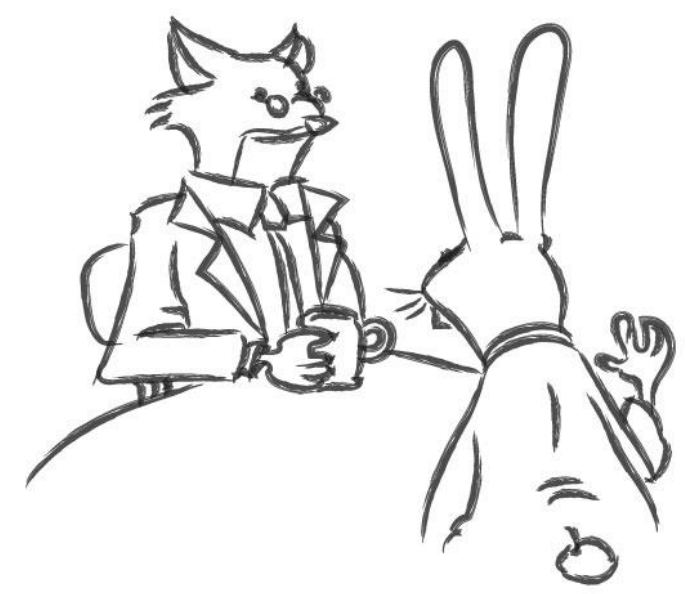

Segunda Fábula

Personagens do diálogo: Eu Renardo; Compadre Coelho

COELHO - Messer Renardo, Messer Renardo, me ajude, por favor.

RENARDO - Que contrariedade the aconteceu, meu pequeno amigo?

COELHO - Não, não, Messer Renardo. Venho pela honra lamentar-me com o senhor.

RENARDO - E que bicho seria esta honra, meu coelhinho? Nunca ouvi falar.

COELHO - Nãoé um bicho, Messer Renardo; é uma palavra que corre entre os homens.

RENARDO - Ah, agora entendo! Por acaso você ouviu dizer que esta palavra corre entre os homens muito mais do que você entre os animais? Deixe-a correr, meu coelhinho! Não faça como os cavalos, que frequentemente empacam por causa de uma sombra. 
COELHO - Não, não é isto, Messer Renardo; o senhor ainda não me entendeu. Os homens dizem que eu sou um bichinho medroso, e o senhor sabe por quê? Porque assim que os vejo eu fujo. Mas posso the dizer, Messer Renardo, que já fiz muitas vezes fugir ratos do campo, grilos, lagartixas, passarinhos, e que se o senhor perguntasse a eles sobre mim, sabe-se lá o que responderiam; certamente não que eu seja um bicho medroso. Ou será que os homens pretenderiam que na presença deles eu me levantasse em duas patas e fosse-lhes ao encontro para me deixar prender e matar? Acho que na verdade entre os homens, Messer Renardo, não deva haver muita diferença entre heroísmo e imbecilidade.

RENARDO - Você diz sempre correr, meu coelhinho! Mas sim, creio que desta vez você diga a verdade. ${ }^{89}$

Mais do que as duas fábulas reportadas acima, há dois pontos no prólogo que merecem uma maior atenção. O primeiro reafirma a transposição da fábula para o ponto de vista da "sábia" raposa, um ponto de vista "distanciado" em relação às costumeiras aparências do mundo humano, o que ao mesmo tempo confirma essas fábulas enquanto fábulas e reverte a ótica tradicional suspeitando, inclusive, que "nas fábulas mais engenhosas de certos moralistas estivesse a patinha da raposa"; o segundo, é a descoberta de que este ponto de vista coincide com as amargas suspeitas de que as razões do sofrimento humano podem ser encontradas dentro do próprio homem, onde se encontra a "toca da besta" e cujas causas, nessa etapa de sua trajetória, Pirandello começa a pesquisar.

Como afirma Elisabetta Bacchereti, a postura da raposa seria

uma palavra "outra" [que] se contrapõe à palavra humana, para transgredir a insensata obtusidade dos lugares comuns, precoce intuição de um modo de representação e nomeação do real, pelo qual, mais tarde, Pirandello cunhará a fórmula de seu original humorismo. ${ }^{90}$

\footnotetext{
${ }^{89}$ PIRANDELLO, Luigi. Saggi, poesie e scritti varii. Milano: Mondadori, 1973, pp. 1046-1049. Ver texto original no final do capítulo.

90 "una parola 'altra' [che] si contrappone a quella umana, per infrangere la stolta ottusità dei luoghi comuni, precoce intuizione di un modo di rappresentazione e nominazione del reale per cui più tardi Pirandello conierà
} 
De fato, na segunda parte de O humorismo (1908), Pirandello, no constante jogo de autocitação, típico de sua obra, retoma em parte essas fábulas:

Também é preciso escutar, meus senhores, as razões do coelho! Uma vez em imaginei que à toca da raposa, ou de Messer Renardo, como esta costuma ser chamada no mundo das fábulas, acorressem um a um todos os animais por causa da notícia que se espalhara entre eles de certas contra-fábulas que a raposa pretendia compor em resposta a todas aquelas que há tempos imemoráveis os homens compõem, e pelas quais eles talvez tenham motivos para se sentirem caluniados. Entre outros animais, também o coelho vinha protestar, na toca de Messer Renardo, contra os homens que o chamavam de medroso, e dizia: "Só sei dizer de minha parte, Messer Renardo, que sempre botei para correr ratos e lagartixas e passarinhos e grilos e muitos outros bichinhos, os quais, se o senhor thes perguntasse que conceito têm de mim, sabe-se lá o que responderiam, certamente não que eu seja um bicho medroso. Ou será que os homens pretenderiam que na presença deles eu me levantasse em duas patas e lhes fosse ao encontro para me deixar prender e matar? Acredito realmente, Messer Renardo, que para os homens não deva haver muita diferença entre heró́smo e imbecilidade!"91

Argumentação semelhante, inclusive com as mesmas palavras, retorna também no Caderno VII, do romance Cadernos de Serafino Gubbio operador (1916):

Mesmo os moralistas mais moralistas, sem querer, nas entrelinhas de suas fábulas deixam entrever um vivo contentamento para com as astúcias da

la formula del suo orig inale u moris mo." BACCHERETI, Elisabetta. "La maschera di Esopo", In Bestiari del novecento (a cura di Enza Biagini e Anna Nozzoli). Roma: Bulzoni Editore, 2001, p. 26.

91 "Bisogna pure ascoltare, signori miei, le ragioni del coniglio! Io lo immaginai una volta che alla tana della volpe, o di Messer Renardo, com'essa si suol chiamare nel mondo delle favole, accorressero a una a una tutte le bestie per la notizia che tra loro s'era sparsa di certe controfavole che la volpe avesse in animo di comporre in risposta a tutte quelle che da tempo immemorabile gli uomini compongono, e da cui esse bestie han forse motivo di sentirsi calunniate. Etra le altre alla tana di Messer Renardo veniva il conig lio a protestare contro gli uomini che lo chiamano pauroso, e diceva: 'Ma ben vi so dire per conto mio, Messer Renardo, che topi e lucertole e uccelli e grilli e tant'altre bestiole ho sempre messo in fuga, le quali, se voi domandaste loro che concetto abbiano di me, chi sa che cosa vi risponderebbero, non certo che io sia una bestia pa urosa. O che forse pretenderebbero gli uomini che al loro cospetto io mi rizzassi su due piedi e movessi loro incontro per farmi prendere e uccidere? Io credo veramente, Messer Renardo, che per gli uomini non debba correre alcuna differenza tra erois mo e imbecillità!" PIRANDELLO, Luigi. "L'umorismo". In Saggi, Poesie e Scritti Varii. Milano: Arnoldo Mondadori Editori, 1993, pp. 142-143. 
raposa em prejuízo do lobo ou do coelho ou da galinha: e Deus sabe o que representa a raposa nessas fábulas! A moral a tirar daí é sempre esta: que o prejuízo e as zombarias são para os tolos, os tímidos, os humildes, e que se deve prezar, sobretudo, a astúcia, mesmo quando não alcança as uvas e diz que ainda não estão maduras. Bela moral! Mas isto é o que sempre diz a raposa aos moralistas, que por mais que façam, nunca conseguem que ela faça uma má figura. Vocês riram da fábula da raposa e das uvas? Eu não, nunca. Porque nenhuma sabedoria me pareceu mais sábia do que esta, que ensina a curar de qualquer vontade desprezando-a. ${ }^{92}$

O tema do animal que habita dentro do homem será posteriormente revisitado mais explicitamente na novela "Não é uma coisa séria" (1910), já em chave humorista, em que o extravagante personagem Perazzetti, com uma irritante "risada de pato", enxerga em cada um de seus conhecidos o "antro da besta", um lugar cavernoso e escuro onde se oculta a "besta originária escondida dentro de cada um de nós, sob todos os estratos de consciência, que aos poucos foram se sobrepondo com os anos" 93 . Besta que está pronta a saltar fora quando provocada em sua toca:

Por fora, a educação; por dentro, o asno que quer logo a forragem. E [Perazzetti] se divertia um mundo a imaginar todas as raças de animais entocadas nos antros dos homens que conhecia: aquele certamente tinha dentro um formigueiro e aquele um porco-espinho e aquele outro um peru, e assim por diante. ${ }^{94}$

\footnotetext{
92 “Anche i piú morali moralisti, senza volerlo, tra le righe delle loro favole lasciano scorgere un vivo compiacimento per le astuzie della volpe a danno del lupo o del coniglio o della gallina: e Dio sa che cosa rappresenta la volpe in quelle favole! La morale da cavarne è sempre questa: che il danno e le beffe restano agli sciocchi, ai timidi, ai semplici, e che sopra tutto da pregiare è dunque l'astuzia, anche quando non arriva all'uva e dice che ancora non è matura. Bella morale! Ma questo tiro giuoca sempre la volpe ai moralisti, che per far che facciano, non riescono mai a farle fare una cattiva figura. Avete voi riso della favola della volpe e dell'uva? Io no, mai. Perché nessuna saggezza m'è apparsa piú saggia di questa, che insegna a guarir d'ogni voglia, disprezzandola." PIRANDELLO, Luigi. Quaderni di Serafino Gubbio operatore. In Tutti i romanzi. Vol. 2. Milano: Arnoldo Mondadori Editore, 1973, p. 716.

93 "besta originaria acquattata dentro a ciascuno di noi, sotto tutti gli strati di coscienza, che gli si sono a mano a mano sovrapposticon gli anni." PIRANDELLO, Luigi. "Non è una cosa seria". Referência: ver Anexo B.

94 "Fuori, la creanza; dentro, l'asino che voleva subito la biada. E si divertiva un mondo a immaginare tutte le razze di bestie rintanate negli antri degli uo mini di sua conoscenza: quello aveva certo dentro un formich iere e quello un porcospino e quell'altro un pollo d'India, e così via." Idem.

Este trecho irá ecoar, alguns anos depois, em um dos aforismos de Barche capovolte (1910-1911), de Federico Tozzi: "Io non so quel che porto dentro di me. Di quassù non posso scorgere i riflessi che avvengono nel
} 
A toca do animal interior é uma constante em toda a obra de Pirandello, e não apenas nas novelas, mas também no teatro, como exclama o personagem Angelo Baldovino do drama O prazer da honestidade (1917): "Não estamos sós! — Somos nós e a besta. A besta que nos conduz." 95 , ou no romance, onde acabará por se materializar no tigre de Cadernos de Serafino Gubbio operador (1925).

A risada de Perazzetti, também animalesca, já que imita o grasnar do pato, parece ecoar por toda obra de Pirandello para denunciar, hegelianamente, a "animalidade" do homem, criando um universo paralelo homem/animal, onde o animal de tão familiar e tão inserido na vida humana muitas vezes passa despercebido. Note-se, porém, que não há na obra pirandelliana animais fantásticos, como em Borges, ou com poderes mágicos e sobrenaturais, como em Maupassant (O Horla). Todos eles são biológica e cotidianamente identificáveis.

profondissimo pozzo dell'anima. Non so se abbia dentro di me una buca di scorpioni o un nido di usignoli” [Não sei o que carrego dentro de mim. Daqui não posso ver os refle xos que acontecem no profundíssimo poço da alma. Não si se tenho dentro de mim u ma toca de escorpiões ou um ninho de rouxinóis.] TOZZI, Federico. Barche capovolte. In Cose e Persone. Firenze: Vallecchi, 1981, pp. 65-113.

95 "Non siamo soli! - Siamo noi e la bestia. La bestia che ci porta.". PIRANDELLO, Luigi. Il piacere dell'onestà. In Maschere nude. Vol I. Milano: Mondadori, 1993, pp. 535-616. 
b) A fábula dentro da narrativa

A lição de Esopo, mesmo com inversão de perspectiva, foi bem assimilada pelo escritor. Em muitas de suas novelas e romances inserem-se pequenas fábulas "criando intertextualidade, metaescritura, experimentação de técnicas narrativas e palimpsestos da fábula esopiana"96 . É o que acontece, exemplarmente, na longa novela epistolar "Notícias do mundo" (1901), onde ao menos três fábulas à maneira de Esopo pontuam as cartas escritas pelo protagonista a seu amigo falecido, nas quais o autor acena para o bom-senso dos animais, com o que ele chama de "animalesca filosofia". Com a intenção de dar "notícias do mundo" ao amigo recentemente morto, o missivista se perde em divagações sobre o sentido da existência mediadas pela observação do comportamento de alguns animais, em chave decididamente fabulista.

Em estreita ligação com as fábulas, ou contra-fábulas, da raposa, as três pequenas narrativas servem de contraponto para as reflexões do protagonista sobre o sentido da vida e da morte. Uma vida toda feita "de clarões e equívocos. [...] De vez em quando, um clarão; mas para ver o quê? Um equívoco. Quer dizer, Momino, a consciência que estaca na sua frente de sobressalto." 97

A primeira delas, de sabor quase leopardiano, reflete sobre o fim das ilusões da juventude, utilizando a dimensão teriomorfa como espelho da dimensão humana:

\footnotetext{
96 “creando intertestualità, metascrittura, sperimentazione di tecniche narrative e palinsesti della favola esopiana."ZANGRILLI, Franco. Il bestiario di Pirandello.Fossombrone:Metauro Edizioni, 2001, p. 12.

97 "a lampi e a cantonate. [...] Ogni tanto, un lampo; ma per veder che cosa? una cantonata. Vale a dire, Momino, la coscienza che ti si para davanti di soprassalto." PIRANDELLO, Luigi. "Notizie del mondo". Referência: ver Anexo B.
} 


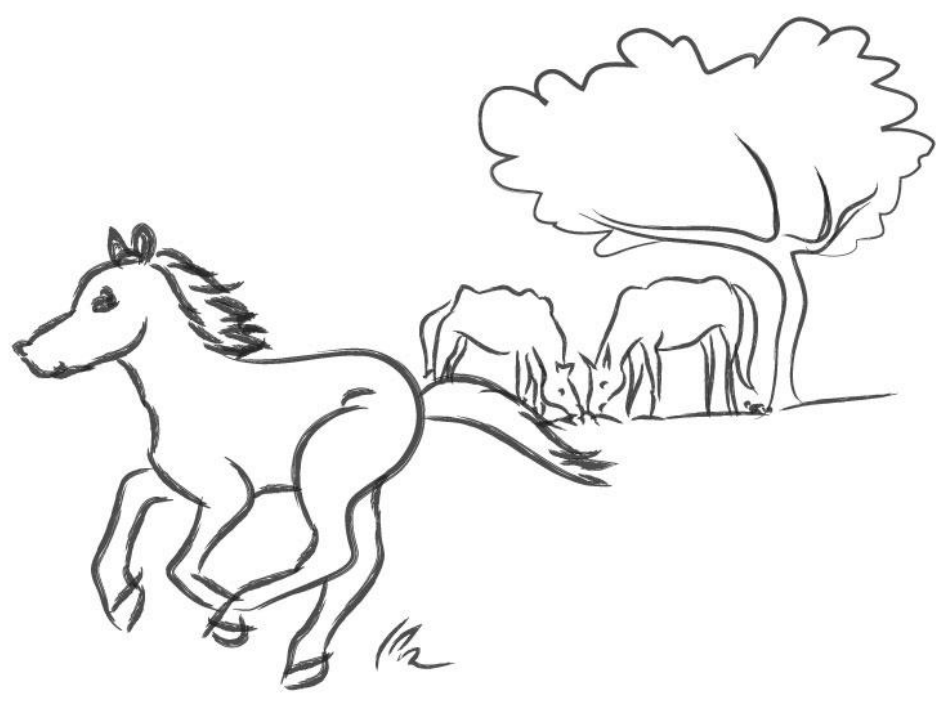

Pela vasta planície, que serve como campo de exercitação para as milícias, um casal de cavalos deixados em liberdade divertia-se perseguindo seu irrequieto potrinho, o qual, correndo de lá para cá e fazendo mil cabriolas e piruetas, demonstrava ter muito prazer com aquela brincadeira. E também parecia que o pai e a mãe, com todo aquele gracioso entusiasmo do filho, sentissem de repente ter retornado à juventude e naquele momento de ilusão se olvidassem. Mas pouco depois, de repente, como se durante a corrida uma sombra tivesse passado diante deles, estacaram, sacudiram várias vezes a cabeça, bufando, e, cansados e lentos, com o pescoço baixo foram deitar um pouco afastados. Em vão o filho tentou animá-los, estimulá-los novamente à corrida e à brincadeira; ficaram ali, sérios e graves, como sob o peso de uma grande melancolia; e um deles, que devia ser o pai, balançando lentamente a cabeça às tentações do potrinho, pareceu-me que com aquele gesto quisesse lhe dizer: "Filho, você não sabe o que the espera..."98

A segunda, um monólogo dirigido a um inseto que caíra num copo d'água, reflete sobre a presunção, a insensatez e a cegueira humanas, transferidas para um pequeno inseto em busca de sobrevivência. O narrador, neste caso, assume o papel do acaso, que caprichosamente pode decidir sobre o destino de cada um, mas não pode modificar sua natureza:

\footnotetext{
${ }^{98}$ PIRANDELLO, Luigi. "Notizie del mondo". Ver texto original no final do capítulo. Referência: ver Anexo B.
} 
...Enquanto escrevo, num copo d'água sobre a escrivaninha caiu um inseto nojento, delgado, de asas chatas, com seis patas, dos quais as últimas duas são longas, muito finas e capazes de impulsionar. Divirto-me vendo-o nadar como um desesperado, e observo com admiração quanta confiança ele tem na ágil virtude daque las suas duas patas. Certamente morrerá obstinando-se a acreditar que eles são bem capazes de dar impulso mesmo sobre o líquido, mas que, no entanto, alguma coisa grudada às suas extremidades impede o salto; de fato, sendo em vão qualquer esforço, procura desembaraçar-se limpando-as fervorosamente com as patas dianteiras.

Devo salvá-lo, Momino, sim ou não?

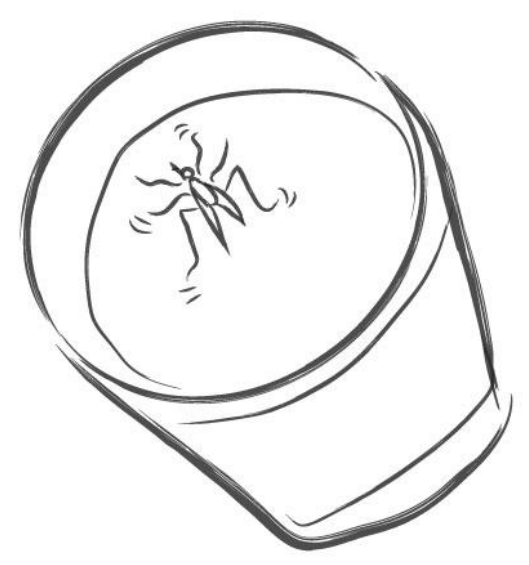

Se o salvo, ele sem dúvida dará o mérito a suas patas: que se afogue, portanto! E se, ao contrário, fosse uma graciosa borboletinha resignada a morrer? Eu já a teria tirado fora há algum tempo, cuidadosamente... Oh caridade humana corrompida pela estética!

Aqui está, ó inseto infeliz, a salvação: enfio a ponta desta caneta na água, depois deixarei você secar um pouco ao calor da lâmpada e por fim vou colocá-lo fora da janela. Mas a água em que você caiu, se me permite, não beberei. E daqui a pouco você, atraído novamente pela luz, talvez volte a entrar no quarto e virá me picar com a pequena tromba venenosa. Cada um faz seu trabalho na vida: eu, o de cavalheiro, e o salvei. Adeus! ${ }^{99}$

\footnotetext{
${ }^{99}$ Idem.
} 
A impossibilidade de encontrar resposta para o mistério da vida, que a ciência torna cada vez mais obscuro em vez de esclarecer, aparece na terceira fábula inserida nesta novela, na qual o diálogo do narrador com um morcego ${ }^{100}$ invisível vai conduzir às mesmas reflexões já feitas por Pirandello nas Fábulas de Messer Renardo, num procedimento de reelaboração e autocitação bastante comuns na obra do autor:

Zrì, de quando em quando. É um morcego invisível, que esvoaça curioso, aqui, diante do espaço luminoso aberto no escuro da praça deserta. Zrì: e parece que está perguntando: "O que você está fazendo?"

- Escrevo para um morto, amigo morcego! E você, o que faz? O que é essa sua vida notívaga? Você esvoaça, e não sabe; assim como eu não sei o que é a minha vida; eu que sei tantas coisas, as quais, no fundo, não me prestaram outro serviço a não ser aumentar perante meus olhos e minha mente o mistério, engrandecendo-o com o conhecimento da pretensa ciência: realmente um belo serviço!

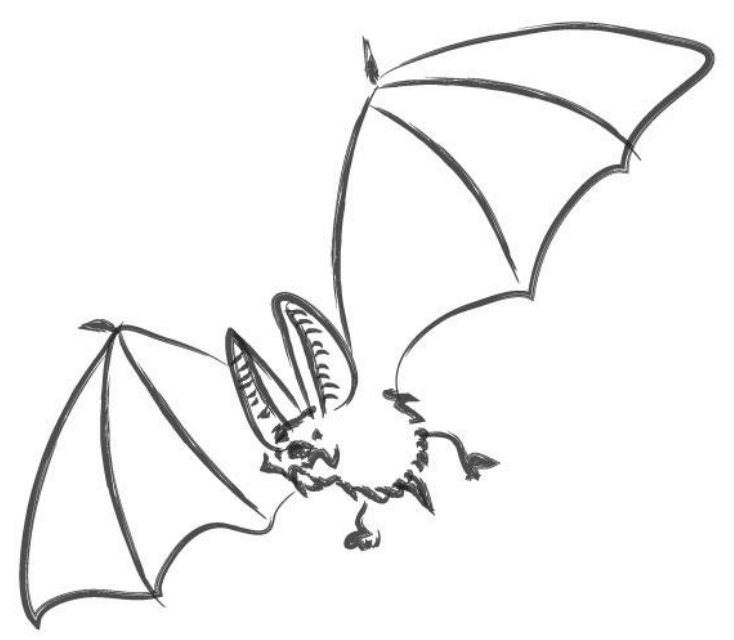

O que você diria, amigo morcego, se um seu semelhante tivesse a ideia de descobrir um aparetho para colocar sob as asas e fazer você voar mais alto e mais depressa? Talvez de início isso o agradasse, mas e depois?

O que importa não é voar mais depressa ou mais devagar, mais alto ou mais baixo, mas saber por que se voa.

\footnotetext{
${ }^{100}$ Outro morcego irá aparecer posteriormente na novela $O$ morcego (1920), símbolo da constante intromissão do acaso na vida humana.
} 
E por que deveria se apressar a tartaruga, condenada a viver uma vida longuíssima?

Em nossas fábulas, no entanto, chamamos de lenta e preguiçosa a tartaruga, a qual, por ter tanto tempo diante de si, não tem nenhuma pressa, e chamamos de medroso o coelho, que assim que nos vê sai correndo.

Mas se perguntássemos sobre o coelho aos ratos do campo, aos grilos, às lagartixas, aos pássaros, sabe-se lá o que nos responderiam, mas não certamente que ele é um animal medroso. Ou será que os homens pretenderiam que o coelho, na presença deles, se erguesse em duas patas e fosse ao seu encontro para ser capturado e morto? Ainda bem que o coelho não nos ouve! Ainda bem que não pensa como nós; de outro modo, teria fundamento acreditar que entre os homens, em geral, não exista muita diferença entre heroísmo e imbecilidade.

E se por acaso a raposa, que tem fama de sábia, tivesse a ideia de compor fábulas em resposta a todas aquelas que há muito tempo os homens compõem caluniando os animais; quanto material não thes ofereceriam, caro morcego, essas descobertas humanas e essa ciência humana.

Mas a raposa não faria isto, porque tenho certeza que com sua sagacidade entenderia que se, por exemplo, um fabulista faz falar um asno como um homem tolo, tolo não é o asno, mas asno é o homem. ${ }^{101}$

A série de fábulas encerra-se com a irônica reflexão do missivista: "Filosofia esta noite, hein? Um tanto animalesca, na verdade, com aqueles cavalos a princípio, e depois com aquele inseto e agora com o morcego e a tartaruga e o coelho e a raposa e o asno e o homem..."102

O procedimento de "filoso far" com animais, criando pequenas fábulas, já era adotado pelo jovem Pirandello em sua correspondência pessoal. V eja-se a carta enviada à irmã Lina, em 31 de outubro de 1886:

\footnotetext{
${ }^{101}$ PIRANDELLO, Luigi. "Notizie del mondo". Ver texto original no final do capítulo. Referência: ver Anexo B.

102 "Filosofia, eh? questa notte: un po' animalesca veramente, con quei cavalli a principio, e poi con quell' insetto e ora il pipistrello e la tartaruga e il coniglio e la volpe e l'asino e l'uomo..." Idem.
} 
Nós somos como as pobres aranhas, que para viver necessitam tecer num cantinho a sua fina teia, nós somos como os pobres caramujos que para viver necessitam carregar sua frágil casca ou como os pobres moluscos que precisam todos de sua concha no fundo do mar. Somos aranhas, caramujos, moluscos de uma raça mais nobre, não queremos uma teia, uma casca, uma concha, mas sim um pequeno mundo para viver nele e viver dele: um ideal, um sentimento, um hábito, uma ocupação - isto é o pequeno mundo, a casca desse caramujão ou homem - como o chamam. ${ }^{103}$

Também na novela “Ao valor civil” (1902), Pirandello retoma esta relação entre o mundo animale o humano, sublinhando como a natureza do animal domina as ações humanas e como o homem é falso por natureza:

Ao chamar os homens de tigres, hienas, lobos, serpentes, macacos ou coelhos, Bruno Celèsia temia fazer uma injúria não merecida àqueles animais, porque cada um deles é conforme e obediente à própria natureza; enquanto o homem! falso homem. E portanto, cuspidas na cara do homem e possivelmente pontapés em outro lugar! $!^{104}$

A “animalesca filosofia" filtrada por Pirandello por meio das fábulas precede e já prefigura as preocupações que o escritor humorista irá amadurecer no desenvolvimento de sua obra. Os animais, aqui, não fogem à tendência de representarem símbolos de vícios e virtudes da fabulística tradicional, mas a inversão da perspectiva antropocêntrica em favor dos animais demonstra que esses dois universos supostamente paralelos se superpõem sem, no entanto, perder suas características próprias. A “indiferença da natureza”, já tema leopardiano, pode

\footnotetext{
103 "Noi siamo come i poveri ragni, che per vivere hanno bisogno di intessersi in un cantuccio la loro tela sottile, noi siamo come le povere lu mache che per vivere han bisogno di portare a dosso il loro guscio fragile o co me $\mathrm{i}$ poveri molluschi che vogliono tutti la loro conchiglia in fondo al mare. Siamo ragni, lu mache, molluschi di una razza più nobile, non vorre mmo una ragnatela, un guscio, una conchiglia, ma un piccolo mondo sì, e per vivere in esso e per vivere di esso: un ideale, un sentimento, un'abitudine, una occupazione - eccolo il piccolo mondo, ecco il guscio di questo lumacone o uomo - come lo chiamano." PIRANDELLO, Luigi. Lettere giovanili da Palermo e da Roma, 1886-1889. Roma: Bulzoni, 1993, p. 148.

104 "Dicendo agli uomini: tigri, jene, lupi, serpi, scimmie o conigli, Bruno Celèsia temeva di fare a quelle bestie un'ingiuria che non si meritavano, perché ciascuna, conforme e obbediente alla propria natura; mentre l'uomo! falso, l'uomo. E dunque, sputi in faccia, all'uomo, e possibilmente calci in un altro posto!" PIRANDELLO, Luigi. "Al valore civile". Referência: ver Anexo B.
} 
levar a reflexões mais profundas sobre os sentimentos humanos. Por outro lado, Pirandello parece querer denunciar a vã tentativa da ciência, e por que não da filosofia, de ordenar a realidade em chave positivista, sem levar em conta essa natureza e o mundo animal como exemplo de conduta e autoconhecimento. 
c) Metamorfoses

ulula e, em vão, esforça-se por falar; de dentro dele próprio a boca extrai a raiva, e, com desejo de morte costumeiro, é convertido em besta e, ainda agora, regala-se com sangue. Vão-se em pelos as vestes; vão-se em patas os braços de Licáon; Faz-se lobo, e da sua velha forma só vestígios conserva: do vulto o mesmo pelo agrisalhado; é a mesma violência, os mesmos são os olhos que reluzem, a imagem de feroz

Ovídio $^{105}$

As lições de Esopo não foram as únicas aprendidas por Pirandello. O contato com os autores latinos, provavelmente durante seus estudos na Alemanha, também foi determinante para a formação do escritor. As citações desses autores na obra de Pirandello são inúmeras, mas sobretudo a influência das Metamorfoses, de Ovídio, que é mais visível em novelas como "Mal de lua" (1913) ou "Ciàula descobre a lua" (1912). As Metamorfoses são provavelmente uma das obras clássicas que mais influenciaram não apenas a literatura, a música e as artes plásticas, mas também a imaginação e as crenças de populações inteiras. Seus 15 livros utilizam ficção e realidade, narrando a transfiguração dos homens e dos deuses mitológicos em animais, árvores, rios ou pedras, mas é talvez o mito de Licáon, transformado em lobo por Júpiter, a transfiguração que mais tenha a estimulado a imaginação humana. A licantropia, o homem que ataca seus semelhantes em noite de lua cheia ao se transformar em lobo, é uma das crendices mais constantes na cultura ocidental e no caso da Sićlia não poderia ser diferente.

\footnotetext{
105 OVÍDIO. “A metamorfose de Licáon, II”, IN Metamorfoses. Antologia de contos. Trad. Marcos Martinho. São Paulo: Companhia das Letras, 2010, pp. 17-18.
} 


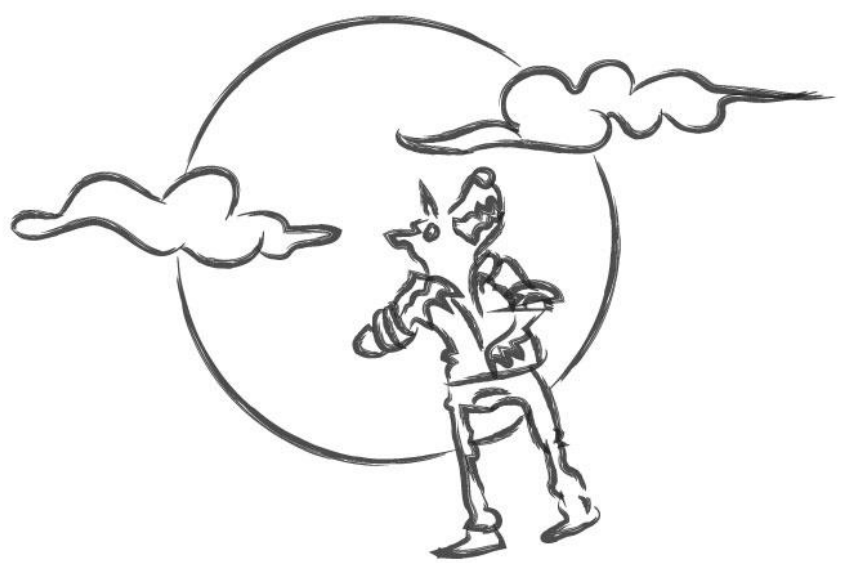

Na novela "Mal de lua" (1913), Pirandello recria, em chave humorista, Licáon na figura de Batà, mediado pelas crendices sicilianas do homem-lobo, num ambiente desolado, sufocante e fora do tempo, quase um dos círculos do inferno dantesco.

Batà é um camponês já entrado nos anos e com algumas posses. Para acabar com a solidão, casa-se com Sidora, uma jovem pobre da cidade e a leva para morar com ele em sua propriedade no campo. O casamento aprovado e desejado pela mãe da moça, além de trazer alguma ajuda financeira à família de Sidora, tivera o objetivo de separar a jovem de seu primo Saro, por quem ela era apaixonada e correspondida.

Batà era considerado esquisitão, “jogado sempre lá, naquele seu pedaço de terra distante, $[\ldots]$ estava sempre sozinho, como um animal em companhia de seus animais, duas mulas, uma jumenta e o cão de guarda; e certamente tinha um ar estranho, sinistro e às vezes insano."106

Logo no primeiro mês de casamento, a jovem descobre que o marido é perturbado por uma força misteriosa que o transforma em lobo, sob o efeito da lua cheia.

\footnotetext{
106 "buttato sempre là, in quel suo pezzo di terra lontano, [...] stava sempre solo, come una bestia in compagnia delle sue bestie, due mule, un'asina e il cane di guardia; e certo aveva un'aria strana, truce e a volte da insensato.” PIRANDELLO, Luigi. "Male di luna". Referência: ver Anexo B.
} 
Batà ganiu de novo, foi sacudido por um possante estremecimento convulsivo, que pareceu multiplicar-the os membros; depois, com uma ondulação de braço indicou o céu e berrou:

- A lua! $!^{107}$

Trancada dentro de casa, por ordem do marido, Sidora presencia toda a transformação do marido, aterrorizada.

Trancada dentro de casa, encolhida como que para impedir que os membros fossem arrancados pelo tremor contínuo, crescente, invencível, também ganindo, enlouquecida pelo terror, ouviu pouco depois os uivos longos, ferozes, do marido que se contorcia do lado de fora, diante da porta, tomado por um mal horrendo que vinha da lua, e batia contra a porta com a cabeça, os pés, os joelhos, as mãos, e a arranhava, como se as unhas tivessem se tornado garras, e bufava, na exasperação de um bestial acesso de raiva, quase como se quisesse arrancar e arrebentar aquela porta, e agora ladrava, ladrava como se tivesse um cão no corpo, e de novo começava a arranhar, a bufar, a uivar, e a bater a cabeça, os joelhos. ${ }^{108}$

A transformação de Batà em lobo é mais de comportamento do que física, voltando aqui a ideia do "antro da besta", do animal que cada um carrega dentro de si e que pode irromper a qualquer momento. Porém, esta ideia mediada pelas superstições da Sicília primitiva, das lendas e da mitologia ovidiana, está muito mais próxima do desdobramento da personalidade, do duplo, mais uma das tantas formas do "eu" que Pirandello utiliza em suas novelas para, pacientemente, dissecar e analisar a alma humana.

\footnotetext{
107 "Batà mugolò di nuovo, si scrollò tutto per un possente sussulto convulsivo, che parve gli moltiplicasse le membra; poi, col guizzo d'un braccio indicò il cielo, e urlò: / - La luna!" Idem.

108 "Asserragliata dentro, tenendosi stretta come a impedire che le me mbra le si staccassero dal tremore continuo, crescente, invincibile, mugolando anche lei, forsennata dal terrore, udì poco dopo gli ù luli lunghi, ferini, del marito che si scontorceva fuori, là davanti la porta, in preda al male orrendo che gli veniva dalla luna, e contro la porta batteva il capo, i piedi, i ginocchi, le mani, e la graffiava, come se le unghie gli fossero diventate artigli, e sbuffava, quasi nell'esasperazione d'una bestiale fatica rabbiosa, quasi volesse sconficcarla, schiantarla, quella porta, e ora latrava, latrava, come se avesse un cane in corpo, e daccapo tornava a graffiare, sbruffando, ululando, e a battervi il capo, i ginocchi." Idem.
} 
A esposa foge para casa da mãe e Batà vai até a cidade para buscá-la, explicando que sofre de um mal que só acontece na primeira noite de lua cheia, pois

a mãe quando jovem, fora colher trigo e dormira no campo, aos sereno, e o deixara, criança, toda a noite exposto à lua; e por toda aquela noite, ele pobre inocente, com a barriguinha para cima, enquanto os olhos fantasiavam, havia brincado com a bela lua, sacudindo as perninhas e os bracinhos. E a lua o havia "encantado". O encanto, porém, dormira dentro dele por anos e anos, e só há pouco tempo acordara. A cada lua cheia, o mal o possuía. ${ }^{109}$

Até este ponto, a novela pode parecer de franca inspiração verista, como alguns críticos a consideram, pelo ambiente siciliano e pela inevitabilidade do destino de cada um, que deve ser cumprido até o fim.

Batà convence Sidora a voltar para casa permitindo que quando da nova transformação a mãe esteja presente e leve consigo Saro. Na lua cheia seguinte, quando o marido é tomado pelo mal, Sidora, a mãe e Saro trancam-se em casa e Sidora, aproveitando a oportunidade de estar sozinha com Saro, se transforma em uma loba faminta por sexo.

Com os cabelos arrepiados na testa, aos primeiros uivos do marido, às primeiras cabeçadas, aos primeiros chutes na porta, às primeiras bufadas e arranhões, Saro, todo banhado de suor frio, com as costas cortadas por arrepios, os olhos arregalados, tremia como vara verde. Não era nada? Senhor Deus! Mas como? Aquela mulher era louca? Enquanto o marido, fora, fazia aquela tempestade na porta, ela aqui, ria, sentada na cama, balançava as pernas, estendia-lhe os braços e o chamava:

- Saro! Saro! ${ }^{110}$

\footnotetext{
109 "la madre da giovane, andata a spighe, dormendo su un'aja al sereno, lo aveva tenuto bambino tutta la notte esposto alla luna; e tutta quella notte, lui povero innocente, con la pancina all'aria, mentre gli occhi gli vagellavano, ci aveva giocato, con la bella luna, dimenando le gambette, i braccini. E la luna lo aveva 'incantato'. L'incanto però gli aveva dormito dentro per anni e anni, e solo da poco tempo gli s'era risvegliato. Ogni volta che la luna era in quintadecima, il male lo riprendeva." Idem.

110 "Coi capelli drizzati su la fronte, ai primi ululi del marito, alle prime testate, alle prime pedate alla porta, ai primi sbruffi e graffii, Saro, tutto bagnato di sudor freddo, con la schiena aperta dai brividi, gli occhi sbarrati, tremava a verga a verga. Non era niente? Signore Iddio! Signore Iddio! Ma come? Era pazza quella donna là?
} 
Esta segunda metamorfose, deixa Saro encurralado entre do is topos da literatura, o homem que se transforma em lobo e a mulher que, por furor uterino, se transforma em loba, tendo como testemunha a causadora de todo este mal, a lua.

E ao retirar-se em direção à porta, [Saro] ele também vislumbrou pela grade da janelinha alta, na parede fronteiriça, a lua que, se do lado de fora causava tanto mal ao marido, lá dentro parecia rir, satisfeita e insolente, da fracassada vingança da mulher. ${ }^{111}$

O tema da mulher-loba já havia sido explorado por Verga na novela "A loba", em que uma mulher apaixona-se pelo marido da filha e tenta seduzi-lo de todas as maneiras, até que ele se vê obrigado a matá-la. A ambientação desta novela e o comportamento da mulher provavelmente levaram parte da crítica a descartar a componente humorista de "Malde Lua", buscando sempre uma relação com a novela de Verga. Obviamente, as relações existem, mas muito mais em função da origem dos escritores do que da poética de cada um. Em Verga, o animal aparece principalmente para sublinhar o caráter de alguns personagens, como, por exemplo, em Tigre real, A história de uma toutinegra, ou mesmo na novela "A loba", ao passo que em Pirandello, como afirma Franco Zangrilli, “o animal também é o portador de outros significados nessa sociedade primordial, e faz parte dos mitos, das crenças, das superstições, dos sortilégios, da visão de fenômenos cósmicos"112. Em "Mal de lua"113, a

Mentre il marito, fuori, faceva alla porta quella tempesta, eccola qua, rideva, seduta sul letto, dimenava le gambe, gli tendeva le braccia, lo chiamava: / - Saro! Saro!' Idem.

111 "E nel ritrarsi verso la porta, [Saro] scorse anch'egli dalla grata della finestrella alta, nella parete di faccia, la luna che, se di là dava tanto male al marito, di qua pareva ridesse, beata e dispettosa, della mancata vendetta della moglie." Ibidem.

112 "l'animale è anche il portatore di altri significati in questa società primordiale, e fa parte dei miti, delle credenze, delle superstizioni, degli incantesimi, della visione di fenomeni cosmici” ZANGRILLI, Franco. Il bestiário di Pirandello. Fossombrone: Metauro Edizioni, 2001. p. 40.

113 "Mal de lua" e "O estorninho e o Anjo Cento e Um" são as únicas novelas em que Pirandello se vale da componente sobrenatural ao incorporar as crendices sicilianas. Em "Mal de lua", ao relatar a conversa das "comari”, ele escreve: "Elas tinham dito à mãe, que aquele homem não era natural, que aquele homem devia esconder dentro de si alguma grande mazela" [Lo avevano detto esse alla madre, che quell'uomo non era naturale, che quell'uo mo doveva nascondere in sé qualche grossa magagna]. PIRA NDELLO, Luigi. "Male di luna". Referência: ver Anexo B. 
alternância de significado atribuída à imagem do lobo provoca o efeito humorista tão caro ao autor, e pode ser relacionado a um dos ícones da poética de Pirandello - a Herma Bifronte pois, no final, a lua ri zombeteiramente do sofrimento dos dois protagonistas.

A lua também está presente em outra novela de inspiração siciliana e, da mesma forma, é agente de uma metamorfose, desta vez bem mais sutil. Em "Ciàula descobre a lua" (1912), uma das muitas novelas em que Pirandello retrata o mundo do trabalho nas minas de enxofre da Sicília, não aparece fisicamente nenhum animal, mas sim o homem bestializado pelo trabalho praticamente escravo.

O protagonista, Ciàula, é um caruso $^{114}$ que trabalha como ajudante de Zí Scarda, um minerador que o utiliza para retirar da mina, como uma besta de carga, o minério extraído e levá-lo até o lado de fora para alimentar os fornos onde é processado. Ao final de uma jornada de trabalho, o capataz Cacciagallina ${ }^{115}$ quer obrigar os mineiros a completar a quota diária permanecendo no trabalho. Todos os mineiros o desobedecem, exceto Zí Scarda que, por ser velho e trabalhar quase de favor na mina, precisa manter o emprego para sustentar a nora e os sete netos deixados pelo filho morto numa explosão da mina quatro anos antes, quando também Zí Scarda perdeu um olho.

Os mineiros estão se aprontando para sair, desobedecendo as ordens de Cacciagallina, quando Zí Scarda, chama Ciàula para voltar ao trabalho. Desde a primeira descrição do personagem, já fica claro seu estado de bestialidade:

Chamou-o com o som com que se chamam as gralhas amestradas:

- Té, pá! té, pá!

\footnotetext{
${ }^{114} \mathrm{Na}$ Sicília, rapaz que trabalha com salário fixo, especialmente em minas de enxofre ou estabelecimento agrícola. (Dicionário Garzanti).

${ }^{115}$ Em muitos personagens pirandellianos, o nome do personagem também reflete sua personalidade. Neste caso "caccia" "gallina", ou en xota galinhas, refere-se à falta de autoridade do personagem apesar do estardalhaço que faz: "- Corpo di... sangue di... indietro tutti, giù tutti di nuovo alle cave, a buttar s angue fino all'alba, o faccio fuoco!". Sobre onomástica em Pirandello, cfr. MARZANO, Pasquale. Quando il nome è "cosa seria". L'onomastica nelle novelle di Luigi Pirandello. Pisa: Edizioni ETS, 2010, p.123.
} 
Ciàula estava se vestindo para voltar ao vilarejo.

Vestir-se para Ciàula significava tirar antes de tudo a camisa, ou o que antes talvez tenha sido camisa: a única vestimenta que, por assim dizer, o cobrisse durante o trabalho. Tirada a camisa, vestia sobre o tórax nu, em que se podiam contar uma a uma todas as costelas, um colete muito largo e longo, recebido de esmola, [...] As pernas nuas, finas e tortas [...] se arrepiavam, lívidas de frio. Se algum de seus companheiros the dava um empurrão e um pontapé, gritando-lhe: - Como você é bonito! - ele abria até as orelhas de abano a boca desdentada num riso de satisfação, depois enfiava os calções, que tinham mais de uma janela aberta sobre as nádegas e os joelhos: envolvia-se num capote de lã todo remendado, e, descalço, imitando maravilhosamente a cada passo o som da gralha - crá! crá! - (por isso o haviam apelidado de Ciàula), dirigia-se para o vilarejo.

- Crá! Crá! - também respondeu aquela noie ao chamado de seu patrão; e apresentou-se a ele completamente nu, apenas com a galanteria daquele colete devidamente abotoado.

- Vá, vá se trocar, - disse Zì Scarda. - Vista novamente o saco e a camisa. Hoje para nós o Senhor não fez anoitecer. ${ }^{116}$

Ciàula, portador de uma doença mental que não o impossibilita para o trabalho, vive dentro da mina praticamente nu, maltratado pelos colegas e comportando-se como um animal. Para sobreviver nesse ambiente agreste, atende ao chamado de seu patrão como uma "gralha amestrada", sem se queixar de nada. Fora da mina, nas horas de repouso, também se comporta como animal:

\footnotetext{
${ }^{116}$ Lo chiamò col verso con cui si chiamava le cornacchie ammaestrate: / - Tè, pà! tè, pà! / Ciàula stava a rivestirsi per ritornare al paese. / Rivestirsi per Ciàula significava togliersi prima di tutto la camicia, o quella che un tempo era stata forse una camicia: l'unico indumento che, per modo di dire, lo coprisse durante il lavoro. Toltasi la camicia, indossava sul torace nudo, in cui si potevano contare a una a una tutte le costole, un panciotto bello largo e lungo, avuto in elemosina, [...]Le gambe nude, misere e sbilenche [...] gli si accapponavano, illivid ite dal freddo. Se qualcuno dei compagni gli dava uno spintone e gli allungava un calcio, gridandogli: - Quanto sei bello! - egli apriva fino alle orecchie ad ansa la bocca sdentata a un riso di soddisfazione, poi infilava i calzoni, che avevano più d'una finestra aperta sulle natiche e sui ginocchi: s'avvolgeva in un cappottello d'albagio tutto rappezzato, e, scalzo, imitando meravigliosamente a ogni passo il verso della cornacchia -cràh! cràh! - (per cui lo avevano soprannominato Ciàula), s'avviava al paese. / Cràh! cràh! - rispose anche quella sera al richiamo del suo padrone; e gli si pre sentò tutto nudo, con la sola galanteria di quel panciotto debitamente abbottonato. / - Va', va' a rispogliarti, - gli disse zi' Scarda. Rimettiti il sacco e la camicia. Oggi per noi il Signore non fa notte. PIRANDELLO, Luigi. "Ciàula scopre la luna". Referência: ver Anexo B.
} 
Todas as noites, ao terminar o trabalho, retornava ao vilarejo com Zì Scarda; e lá, assim que terminava de engolir os restos da sopa, jogava-se para dormir num grande saco palha no chão, como um cão; e em vão os meninos, os sete netos órfãos do seu patrão, o chutavam para mantê-lo acordado e rir de sua idiotice; caía logo num sono de chumbo, do qual, todas as manhãs, ao despontar da aurora, costumava despertá-lo um conhecido pé. ${ }^{117}$

Dentro da mina não teme nada, mas como um animal diurno, fora dela teme o escuro da noite:

Tinha medo, entretanto, do escuro vazio da noite.

Conhecia o escuro do dia, lá embaixo, entremeado de suspiros de luz, a lém do funil da escada, por onde subia tantas vezes ao dia, com o seu insólito crocitar de gralha estrangulada. Mas não conhecia o escuro da noite. ${ }^{118}$

Trabalhar dentro da mina não o assusta, mas levar sua carga para fora e saber que é noite o apavora. Ciàula não é apenas excluído da convivência humana, mas também do ambiente natural. Vive como um animal subterrâneo, uma toupeira escavando cada vez mais fundo e onde "ficava cego e seguro como dentro do ventre materno" ${ }^{119}$. As entranhas da montanha, mais uma vez passíveis de comparação com um dos círculos do inferno, a nudez, a falta de articulação e a saída para a luz do dia podem ser entendidas como um nascimento que se repete diariamente, várias vezes por dia, mas um nascimento que, pela repetição, não concede à Ciàula a consciência da própria realidade, refletindo, assim, seu estado de animalidade. Sobre este personagem, afirma Zangrilli ao compará-lo ao personagem de Verga

\footnotetext{
${ }^{117}$ Ogni sera, terminato il lavoro, ritornava al paese con zi' Scarda; e là, appena finito d'ingozzare i resti della minestra, si buttava a dormire sul saccone di paglia per terra, co me un cane; e invano i ragazzi, quei sette nipoti orfani del suo padrone, lo pestavano per tenerlo desto e ridere della sua sciocchezza; cadeva subito in un sonno di piombo, dal quale, ogni mattina, alla punta dell'alba, soleva riscuoterlo un noto piede. Idem.

${ }^{118}$ Aveva paura, invece, del bujo vano della notte. / Conosceva quello del giorno, laggiù, intra me zzato da sos piri di luce, di là dall'imbuto della scala, per cui saliva tante volte al giorno, con quel suo specioso arrangolio di cornacchia strozzata. Ma il bujo della notte non lo conosceva. Idem.

${ }^{119}$ ci stava cieco e sicuro come dentro il suo alvo materno. Idem.
} 
Rosso Malpelo ${ }^{120}$ : “são-lhe negados os pensamentos, as ideias, as aspirações de realizar-se, todos os sonhos e as 'qualidades' do homem"121

Gradativamente, num jogo de luz e sombra, Pirandello vai preparando seu personagem-animal para a metamorfose, para o (re)nascimento governado pela lua:

Moveu-se sob a enorme carga, que também requeria um esforço de equilíbrio. Sim, pronto, sim, podia se mover, pelo menos enquanto caminhava no plano. Mas como erguer aquele peso, quando começasse a subida? [...]

A escada era tão íngreme, que Ciàula, com a cabeça retesada e esmagada sob a carga, depois de chegar à curva, por mais que esticasse os olhos para olhar para cima, não podia enxergar a abertura que se abria no alto.

Curvo, quase tocando com a fronte o degrau acima dele, e sobre cuja superfície escorregadia o lampiãozinho vacilante refletia apenas uma fraca luz avermelhada, ele ia subindo, subindo, subindo, do ventre da montanha, sem prazer, mas assustado diante da libertação que se aproximava. E ainda não via a abertura, que bem lá em cima abria-se como um olho claro, com uma deliciosa claridade prateada. ${ }^{122}$

Por fim, o túnel se abre para a noite que, contra todos os temores de Ciàula, não está envolta em trevas como a vira, apenas uma vez, quando da explosão da mina que matara o filho de Zì Scarda, e da qual sentira tanto medo. A lua cheia reina soberana sobre aquele ambiente de mineração, iluminando e pintando de prata a paisagem tão familiar ao rapaz.

\footnotetext{
${ }^{120}$ Não é o caso aqui de comparar os dois personagens, como tantos críticos o fizeram mostrando semelhanças e diferenças em relação à poética dos dois autores.

121 "gli vengono negati i pensieri, le idee, le aspirazioni di realizzare se stesso, tutti i sogni e le 'qualità' dell'uomo" ZANGRILLI, Franco. Il bestiário di Pirandello. Fossombrone:Metauro Edizioni, 2001. p. 52.

122 "Si mosse sotto il carico enorme, che rich iedeva anche uno sforzo d'equilibrio. Sì, ecco, sì, poteva muoversi, almeno finché andava in piano. Ma come sollevar quel peso, quando sarebbe cominciata la salita? [...] / La scala era così erta, che Ciàula, con la testa protesa e schiacciata sotto il carico, pervenuto all'ultima svoltata, per quanto spingesse gli occhi a guardare in su, non poteva veder la buca che vaneggiava in alto. / Curvo, quasi toccando con la fronte lo scalino che gli stava di sopra, e su la cui lubric ità la lumierina vacillante rifletteva appena un fioco lu me sanguigno, egli veniva su, su, su, dal ventre della montagna, senza piacere, an zi pauroso della prossima liberazione. Enon vedeva ancora la buca, che las sù lassù si apriva come un occhio chiaro, d'una deliziosa chiarità d'argento." PIRANDELLO, Luigi. "Ciàula scopre la luna”. Referência: ver Anexo B.
} 


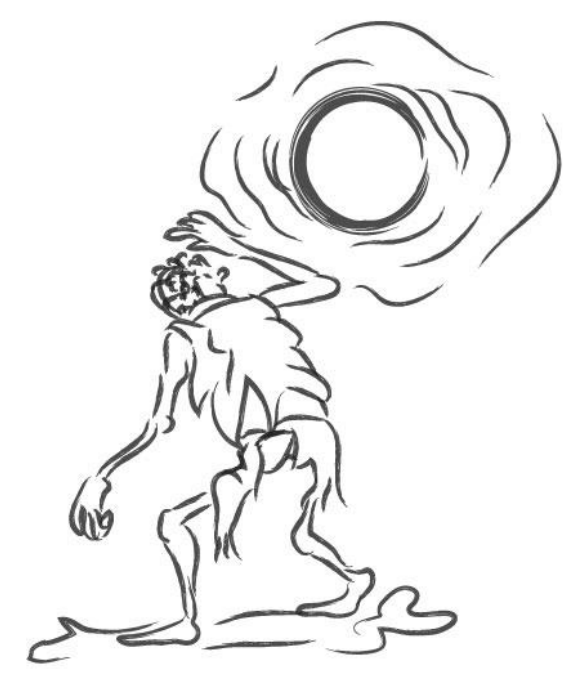

Sim, ele sabia, sabia o que era, mas como tantas outras coisas que se sabe e nunca se deu importância. E o que podia importar a Ciàula, que no céu estivesse a Lua?

Agora, somente agora, tendo saído, de noite, do ventre da terra, ele a descobria.

Extático, sentou-se sobre sua carga, diante da abertura. Ali estava, ali estava ela, ali estava ela, a Lua... Existia a Lua! a Lua!

E Ciàula começou a chorar, sem saber, sem querer, pelo grande conforto, pela grande doçura que sentia, ao tê-la descoberto, lá, enquanto ela subia no céu, a Lua, com seu amplo véu de luz, ignara dos montes, das planícies, dos vales que iluminava, ignara dele, que também não tinha mais medo dela, nem se sentia mais cansado, na noite agora plena de seu espanto. ${ }^{123}$

Liberto do fardo da carga, longe dos outros, Ciàula pode finalmente resgatar sua humanidade e numa imensa solidão "olha a natureza e reconhece a injustiça que o privou da harmonia com ela e que o irmão homem sempre o manteve num degrau inferior ao do

\footnotetext{
123 "Sì, egli sapeva, sapeva che cos'era; ma come tante cose si sanno, a cui non si è dato mai importanza. E che poteva importare a Ciàula, che in cielo ci fosse la Luna? / Ora, ora soltanto, così sbucato, di notte, dal ventre della terra, egli la scopriva. / Estatico, cadde a sedere sul suo carico, davanti alla buca. Eccola, eccola là, eccola là, la Luna... C'era la Luna! la Luna! / E Ciàula si mise a piangere, senza saperlo, senza volerlo, dal gran conforto, dalla grande dolcezza che sentiva, nell'averla scoperta, là, mentr'ella saliva pel cielo, la Luna, col suo ampio velo di luce, ignara dei monti, dei piani, delle valli che rischiarava, ignara di lui, che pure per lei non aveva più paura, né si sentiva più stanco, nella notte ora piena del suo stupore." Idem.
} 
animal" ${ }^{124}$. Sobrevém o pranto, o primeiro pranto, o pranto primordial de toda a criatura humana.

A metamorfose de Ciàula, diferentemente e em sentido contrário da metamorfose de Batà, é uma amarga constatação da condição humana, da animalização a que estão submetidos os mais desvalidos, aqueles que são obrigados a anular sua natureza para sobreviver. Na condição de animais, não há máscara, o papel a ser representado é o da anulação.

"C iàula descobre a lua" é, talvez, a mais dura e a mais poética das novelas do autor siciliano. Saturada de um humorismo cáustico e devastador aponta, em seu desfecho, para o último Pirandello, o Pirandello dos mitos como redenção para a infelicidade humana.

\footnotetext{
124 “mira la natura e riconosce l'ingiustizia che lo ha privato dell'armonia con essa e che il fratello uomo lo ha sempre tenuto in un gradino inferiore a quello dell'animale." ZANGRILLI, Franco. Il bestiário di Pirandello. Fossombrone: Metauro Edizioni, 2001. p. 54.
} 


\section{TEXTOS ORIGINAIS}

Le nostre favole

Sono entrato jeri nella rimessa, giù nel cortile di casa mia, e ad un bellissimo bajo di preclara intelligenza ho voluto leggere, prima, alcune favole di Fedro e poi cert'altre del La Fontaine.

Mentre leggevo, sono anche entrati nella rimessa, a sentire, il corvo del portinajo, che ha le ali mozze e un campanellino al collo, un cane randagio, un gatto e due piccioni.

Orbene, non potete credere quali e quanti segni d'ilarità abbiano dato quelle bestie alla mia lettura. Vi assicuro che esse mi han lasciato intendere chiaramente che tutte quante le favole inventate dagli uomini, da Esopo in poi, non sono altro che amenissime calunnie e graziose corbellerie.

Un leone, una volta, per fame si mangiò un vecchio negro sperduto nel deserto, malaticcio, ridotto proprio pelle e ossa. Se lo mangiò tutto senza dargli nemmeno una rosolatina così sopra sopra. Poco dopo, dietro una tenda ascoltò i discorsi di due esploratori che, svogliati, senza punto aver fame, avevano scannato un giovane cammello che da alcuni mesi li serviva umile e paziente; lo avevano fatto a pezzi, se l'erano cucinato e poi avevano buttato via la carne, dicendo:

- Non è cotta bene!

Chi può levare dal capo al leone, signori miei, che la qualifica di animale feroce attribuita a lui dagli uomini non significhi animale dabbene, stupido animale e sopra tutto ignorante di cucina?

\section{Le Favole Della Volpe}

Da un pezzo ero entrato in sospetto che qua e là nelle favole più argute di certi moralisti fosse lo zampino della volpe. Ma poi, più a lungo riflettendo e man mano rileggendo quasi tutte le favole che fino ai nostri dí, in prosa e in versi, si sono ripetute, conclusi:

— No! Io calunnio la volpe.

E il primo sospetto m'era appena passato, che subito un altro, non so come, me ne cadde in animo: che della volpe, cioè, o di Messer Renardo, come alcuni moralisti han voluto chiamarla, dovessero in qualche parte esistere favole originali. 
Mi posi allora a cercare ansiosamente, per quanto senza indizio veruno: cercai, frugai in grotte e in tane, per le campagne, nelle rotture e caverne delle rupi, nei cavi tronchi d'alberi centenarii, ma purtroppo senz'alcun frutto. Passarono parecchi anni, durante i quali io, a mie spese, tristissimamente imparai a conoscere in ben altro modo e gli uomini e la vita; e più non pensavo a rinvenir le supposte favole della volpe, allorché tutt'un tratto, una mattina, m'avvenne di scoprire la tana, ove Messer Renardo aveva depositato le tanto cercate sue favole.

Era questa tana proprio dentro di me. Io non l'avrei mai sospettato. Era nel cervello, cosí come gli uomini con le loro inimicizie e la fortuna con la sua avversità me lo avevano ridotto.

Ora son lieto di poter dare in saggio qui due di queste novissime favole, che sono tutte in forma di dialogo. Quanto alle altre, vedranno, io spero, la luce, quando il loro autore più non la vedrà.

\section{Favola Prima}

Persone del dialogo: Io Renardo; Un mio vicino

VICINO - È poi vera, Messer Renardo, la novella che tra noi libere bestie signore dei mondo...

RENARDO - Parlate basso, caro vicino.

VICINO - Perche ridete, MesserRenardo?

RENARDO - Rido? No; penso che questa della libertà e della signoria del mondo dev'essere certo comune malattia a tutti gli abitatori e i nati su la terra. Poco fa, innanzi che voi veniste, mi spassavo a udire due uccellini, i quali su quell'albero di fronte dicevan l'aria e tutto quanto il cielo fatti per loro, e che essi ne sono gli assoluti signori. E lo stesso, sú per giú, dicono gli uomini intorno alla terra. Ma gli uomini dicono anche, e fanno tante altre cose, che né gli uccelli, veramente, né fra noi alcuna bestia ha mai pensato di dire o di fare.

VICINO - Come sarebbe, Messer Renardo? Neghereste voi...

RENARDO - Non nego mai nulla io, caro vicino. Dico tutt'al più che la ragione sta sempre dalla parte vostra, ma che, con licenza, io la penso in diverso modo. Basta. Qual novella, seguitando, s'è divulgata tra voi libere bestie (io mi dico servitor vostro umilissimo) signore del mondo?

VICINO - Che voi abbiate in animo di compor favole, in risposta a tutte quelle che da gran tempo gli uomini van mettendo fuori contro di noi.

RENARDO - Novella, amico mio! No contro gli uomini, bensí contro le bestie, se mai, a fin però intendiamoci! — di correggerne i difetti.

VICINO - Gran mercé, Messer Moralista! Ah, vi siete dunque imbrancato anche voi tra quelle vilissime bestie, che per fascino si son lasciate addomesticare dagli uomini e ora insieme con essi ci muovono guerra? Rallegramenti! Rallegramenti!

RENARDO - Non c'è di che, caro vicino. Dunque voi credete che gli uo mini nelle loro favole abbiano detto male di noi? Nemmen per sogno! Ci han fatto pensare con la loro bella testa, ci han 
messo in bocca le loro dotte parole, ma per ritrarre solamente la loro sciocchezza e i loro vizii. Ne volete un esempio? Se un favolista fa parlare un asino come un uomo sciocco, sciocco è 1'asino, caro vicino? Asino è 1'uomo!

Favola Seconda

Persone dei dialogo: Io Renardo; Compar Coniglio

CONIGLIO - MesserRenardo, MesserRenardo, mi raccomando a voi.

RENARDO - Che contrarietà t'è mai occorsa, mio piccolo amico ?

CONIGLIO - No, no, MesserRenardo. Io vengo per 1'onore a lagnarmi con voi.

RENARDO - E che bestia sarebbe mai codest'onore, coniglietto mio? Non l'ho sentito mai nominare.

CONIGLIO - Non è una bestia, Messer Renardo; è una parola che corre tra gli uomini.

RENARDO - Ah, intendo ora! Hai forse udito dire che codesta parola corre tra gli uo mini ben più che tu non faccia tra gli animali? Lasciala correre, coniglietto mio! Non fare come i cavalli, che spesso perun'ombra s'impuntano.

CONIGLIO - No, non è questo, Messer Renardo; non mi avete ancora inteso. Dicono gli uomini ch'io sono una bestiolina paurosa, e sapete perché? Perché, appena li vedo, scappo via. Ma vi so dire, Messer Renardo, che pur io ho tante volte messo in fuga topi di campagna, grilli, lucertole, uccelli, e che se voi demandaste a costoro notizia di me, chi sa che cosa vi risponderebbero; non certo però ch'io sia una bestia paurosa. Oh che forse pretenderebbero gli uomini, che al loro cospetto io mi rizzassi su due piedi e movessi loro incontro per farmi prendere e uccidere? Credo in verità che tra gli uomini, Messer Renardo, non debba correre molta differenza tra eroismo e imbecillità.

RENARDO - Tu dici sempre correre, coniglietto mio! Ma si, credo anch'io questa volta che tu dica la verità.

I cavalli e il puledretto

Per la vasta pianura, che serve da campo d'esercitazione alle milizie, una coppia di cavalli lasciati in libertà si spassavano a rincorrere un loro puledretto vivacissimo, il quale, springando di qua e di là e facendo mille sgambetti e giravolte, dimostrava di prender tanta allegre zza di quel giuoco. E anche il padre e la madre pareva che da tutto quel grazioso tripudio del figlio si sentissero d'un tratto ritornati giovani e in quel mo mento d'illusione si obliassero. Ma poco dopo, d'un tratto, come se nella corsa un'o mbra fosse passata loro davanti, s'impuntarono, scossero più volte, sbruffando, la testa e, stanchi e tardi, col collo basso andarono a sdrajarsi poco discosto. Invano il figlio cercò di scuoterli, di aizzarli novamente alla corsa e al gioco; rimasero lì serii $\mathrm{e}$ gravi, come sotto il peso d'una grande malinconia; e uno, che doveva essere il padre, scrollando lentamente la testa alle tentazioni del puledrino, mi parve che con quel gesto volesse significarg li: "Figlio, tu non sai ciò che t'aspetta..." 
L'ins etto nel bicchiere

...Mentre scrivo, in un bicchier d'acqua sul tavolino è caduto un insetto schifoso, esile, dalle ali piatte, a sei piedi, dei quali gli ultimi due lunghi, finissimi, atti a springare. Mi diverto a vederlo nuotare come un disperato, e osservo con ammirazione quanta fiducia esso serbi nell'agile virtù di que' due suoi piedi. Morrà certo ostinandosi a credere che essi sono ben capaci di springare anche sul liquido, ma che intanto qualcosina attaccata alle estremità gl'impicci nel salto; difatti, riuscendo vano ogni sforzo, coi piè davanti, nettandoli vivacemente, cerca distrigarsene.

Lo salvo, Momino, sì o no?

Se lo salvo, esso senza dubbio ne darà merito ai suoi piedi: affoghi dunque! E se invece fosse una graziosa farfallina rassegnata a morire? L'avrei tratta fuori da un pezzo, accuratamente... Oh carità umana corrotta dall'estetica!

Ecco, o insetto infelice, il salvataggio: caccio la punta di questa penna nell'acqua, poi ti farò asciugare un po' al calore del lume e infine ti metterò fuori della finestra. Ma l'acqua in cui sei caduto, se permetti, non la berrò. E di qui a poco tu, attirato novamente dal lume, forse rientrerai nella stanza e verrai a punzecchiarmi con la piccola proboscide velenosa. Ognuno fa il suo mestiere nella vita: io, quello del galantuomo, e t'ho salvato. Addio!

\section{Il pipistrello invisibile}

Zrì, di tratto in tratto. È un pipistrello invisibile, che svola curioso, qui, davanti al vano lu minoso aperto nel bujo della piazza deserta. Zrì: e par che mi domandi: "Che fai?"

- Scrivo a un morto, a mico pipistrello! E tu che fai? Che cosa è mai codesta tua vita nottambula? Svoli, e non lo sai; come io, del resto, non so che cosa sia la mia; io che pure so tante cose, le quali in fondo non mi hanno reso altro servizio che quello di crescere innanzi a gli occhi miei, alla mia mente, il mistero, ingrandendomelo con le cognizioni della pretesa scienza: bel servizio davvero!

Che diresti tu, amico pipistrello, se a un tuo simile venisse in mente di scoprire un apparecchio da aggiustarti sotto le ali per farti volare più alto e più presto? Forse dapprima ti piacerebbe, ma, e poi?

Quel che importa non è volare più presto o più piano, più alto o più basso, ma sapere perché si vola.

E perché dovrebbe affrettarsi la tartaruga condannata a vivere una lunghissima vita?

Nelle nostre favole intanto chiamiamo tarda e pig ra la tartaruga, la quale, per aver tanto tempo davanti a sé, non si dà nessuna fretta, e chiamiamo pauroso il coniglio che al primo vederci scappa via.

Ma se ai topi di campagna, ai grilli, alle lucertole, agli uccelli, noi domandassimo notizia del coniglio, chi sa che cosa ci risponderebbero, non certo però, che sia una bestia paurosa. $\mathrm{O}$ che forse pretenderebbero gli uomini che, al loro cospetto, il coniglio si rizzasse su due piedi e movesse loro incontro per farsi prendere e uccidere? Meno male che il coniglio non ci sente! meno male che non ha testa da ragionare a modo nostro; altrimenti avrebbe fondamento di credere che spesso tra gli uomini non debba correre molta differenza tra eroismo e imbecillità. 
E se per caso alla volpe, che ha la fama di savia, venisse in mente di comporre favole in risposta a tutte quelle che da gran tempo gli uomini van mettendo fuori calunniando le bestie; quanta materia non le offrirebbero queste scoperte umane, pipistrello mio, e questa scienza umana.

Ma la volpe non ci si metterebbe, perché son sicuro che con la sua sagacia intenderebbe che, se per modo d'esempio, un favolista fa parlare un asino come un uomo sciocco, sciocco non è l'asino, ma asino è l'uomo. 


\section{A máscara animal}

Muitas e muitas vezes, olhando meus semelhantes e vendo-os andar de lá para cá, desenvoltos e com ar de quem entende alguma coisa, na vida que somos condenados a viver nessa mísera bolinha, perguntei a mim mesmo:

- Mas eles fazem realmente a sério?

E, espantado de ser apenas eu a não entender nada, voltei-me aos animais e me esforcei para penetrar em suas mentes para adivinhar o que eles pensam da vida dos homens.

Tive uma vaga suspeita - já faz algum tempo - de que devo estar em perfeitíssimo acordo com os animais ao julgar os meus semelhantes e a vida. $^{125}$

125 "Spessissimo, guardando i miei simili e vedendoli andare di qua e di là, svelti e con l'aria di capirci qualcosa, nella vita che siamo condannati a vivere su questa misera pallottola, ho domandato a me stesso: / - Ma fanno essi sul serio, veramente? / E, sbigottito d'esser solo, io, a non capirci nulla, mi sono voltato alle bestie e sforzato di penetrare nelle loro teste per indovinare che cosa esse pensino della vita degli uo mini. / Ho avuto un vago sospetto - da un pezzo, ormai - che io debba trovarmi in perfettissimo accordo con le bestie nel giudicare i miei simili e la vita." PIRANDELLO, Luigi. "Scritti di argo mento vario", In Saggi, Poesie e Scritti varii. Milano: Arnoldo Mondadori Editore, 1993, p. 1051. 
A incursão de Pirandello no mundo das fábulas (ou contra-fábulas) de tipo esópico deve-se, principalmente, ao período de formação do escritor. No entanto, a presença dos animais não se resume apenas às fábulas, eles são uma constante na obra narrativa do autor e, na evolução de sua obra, comparecem cada vez mais com mais frequência. Mais facilmente identificáveis nas novelas, mas não menos importantes para o desenvolvimento da trama dos romances, os animais muitas vezes enfatizam situações ou são usados como metáfora dos sentimentos humanos, mas não apenas isso. Sobretudo a partir de O falecido Mattia Pascal (1904), que tradicionalmente "inaugura" a fase já destacada do verismo e voltada para o humorismo, os animais ganham espaço e significado emblemático na narrativa de Pirandello.

Nos romances, a presença de animais, além daqueles usados para a simples contextualização de uma paisagem, como elementos complementares ao entrecho ou destinados à caracterização física ou psicológica de personagens, está mais voltada para comentar ou reforçar algumas ideias, conceitos ou atitudes dos persona gens humanos. Só para dar alguns exemplos, temos em O falecido Mattia Pascal (1904) os ratos, os gatos e as aranhas da biblioteca de Miragno, como metáfora do pouco caso das autoridades para com os bens culturais e introduz o tema da impossibilidade de escrever romances como nos moldes daqueles do século XIX (cap. V, "Maturação"); a toupeira como símbolo do fim da pequena aristocracia rural e das mudanças sociais (cap. III, “A casa e a toupeira”); ou mesmo o canário na gaiola ${ }^{126}$ que dá consciência a Mattia da alienação e da solidão em que vive, andando de

\footnotetext{
126 “Lá, num corredor, pendurada no vão de uma janela, havia u ma gaiola com um canário. Já que não podia conversar com os outros e não sabendo o que fazer, punha-me a falar com ele: imitava seu gorjeio com os lá-
} 
hotel em hotel, em busca de uma identidade (cap. IX, "Um pouco de névoa"). Em Cadernos de Serafino Gubbio operador, de 1916, temos o tigre como símbolo da liberdade dos instintos e das paixões, espelho da "mulher-tigre" e da bestialidade humana, bem como o tema da natureza exilada e aprisionada. Em $O$ marido dela ou Giustino Roncella nascido Boggiòlo, de 1911, temos o papagaio que repete incansavelmente o refrão "o que se pode fazer?" como contraponto ao niilismo de Ippolito Roncella, tio da protagonista, a escritora Silvia Roncella, e personagem dedicado ao "ócio filosófico".

No entanto, é nas novelas que o personagem animal se realiza plenamente. Personagem no sentido de "atuante", segundo a terminologia de Greimas ${ }^{127}$, ou seja, aquele que executa ou sofre a ação, gramaticalmente sujeito ou objeto da narrativa ${ }^{128}$. O personagem, tão caro à poética de Pirandello, muitas vezes toma nas novelas as feições do animal, sobretudo quando se trata de compreender o humano pelo olhar do outro, um questionamento que mais tarde se fará Jacques Derrida em O animal que logo sou (A seguir).

Como todo olhar sem fundo, como os olhos do outro, esse olhar dito "animal" me dá a ver o limite abissal do humano: o inumano ou o a-humano, os fins do homem, ou seja, a passagem das fronteiras a partir da qual o homem ousa se anunciar a si mesmo, chamando-se assim pelo nome que ele acredita-se dar $^{129}$.

bios, ele parecia achar que alguém estivesse falando com ele e escutava, talvez apreendesse no meu pipilar notícias de ninhos, folhas, liberdade... Agitava-se na gaiola, voltava-se, saltava, olhava de lado sacudindo a cabecinha e me respondia, perguntava, tomava a escutar. Pobre passarinho!" [Là, in un corridojo, sospesa nel vano d'una finestra, c'era una gabbia con un canarino. Non potendo con gli altri e non sapendo che fare, mi mettevo a conversar con lui, col canarino: gli rifacevo il verso con le labbra, ed esso veramente credeva che qualcuno gli parlasse e ascoltava e forse coglieva in quel mio pispissìo care notizie di nidi, di foglie, di libertà... Si agitava nella gabbia, si voltava, saltava, guardava di traverso, scotendo la testina, poi mi rispondeva, chiedeva, ascoltava ancora. Povero uccellino!] PIRANDELLO, Luigi. Il fu Mattia Pascal. In "Tutti i romanzi", Vol. I. Milano: Arnoldo MondadoriEditore, 1973, p. 430.

127 GREIMAS, A. J. Sêmantica estrutural: método de pesquisa. Trad. Haquira Osakabe e Izidoro Blikstein. São Paulo: Editora Cultrix, 1976, pp. 225-250.

${ }^{128}$ Além da relação sujeito-objeto Greimas também identifica na narrativa as relações de destinador (aquele que anuncia ou proporciona a ação) e destinatário (aquele a quem a ação está dirigida), e de adjuvante (que facilita a ação) e oponente (que dificulta a ação).

${ }^{129}$ DERRIDA, Jacques. O animal que logo sou. (A seguir). Trad. Fábio Landa. São Paulo: Editora UNESP, 2002, p. 31. 
a) o animal e o espelho

O espelho é um dos elementos fundamentais na obra de Pirandello, é nele que o personagem procura ver-se viver e não se reconhece, é nele que a forma toma o lugar da vida. Em algumas novelas, o personagem vê espelhadas suas angústias e limitações nos animais, que atuam como sua contra-imagem, permitindo que se revele a "pena de viver". Olhar-se viver é o que tenta fazer Vitangelo Moscarda diante do espelho, em Um, nenhum e cem mil (1926), mas só consegue obter de volta um arremedo de si mesmo; diante do espe lho o protagonista sem nome da novela "Sopro" (1931) liberta-se da forma, numa onírica dissolução; diante do espelho, Lamberto Laudisi, personagem que comenta os acontecimentos em Assim é (se lhes parece) (1917), parábola em três atos baseada na novela "A senhora Frola e o senhor Ponza, seu genro" (1917), conversa consigo mesmo sobre as questões, também caras a Pirandello, da identidade.

Mas os animais não se reconhecem no espelho, não se fazem perguntas e muito menos tentam ver-se viver. Como observa Pirandello na abertura da novela "O marido de minha mulher" (1903), os animais não são animais metafísicos como o homem: "O cavalo não sabe que deve morrer, e não se faz tais perguntas. Ao homem, porém, que - segundo a definição de Schopenhauer - é um animal metafísico (que significa justamente UM ANIMAL QUE SABE QUE DEVE MORRER), essa pergunta está sempre presente." (itálico e maiúsculas do autor). ${ }^{130}$

Em muitas novelas, os animais são os espelhos que refletem a insensatez e a angústia da vida humana, indiferentes a elas, seguindo apenas seus instintos.

\footnotetext{
130 "Il cavallo non sa di dover morire, e non si fa di queste domande. All'uomo però, che - secondo la definizione di Schopenhauer - è un animale metafisico (che appunto vuol dire UN ANIMALE CHE SA DI DOVER MORIRE), quella domanda sta sempre davanti." PIRANDELLO, Luigi. "Il marito di mia mog lie". Referência: ver Anexo B.

Este tema depois será completamente des envolvido na novela “A sorte de ser cavalo" (1935).
} 
Em “Bolinha e Mimi”, novela de 1905, aparentemente há uma história de amor entre dois cachorrinhos, e o próprio título já evoca a história de outros casais, como Romeu e Julieta ou Paolo e Francesca. Bolinha é um animalzinho feio, sem cauda, o único sobrevivente de uma ninhada trucidada pelo dono que não queria mais cães por estar velho e não poder mais se dedicar à caça. Poupado a pedido das crianças da casa e graças ao fato de não ter cauda (o dono pegava os filhotes pela cauda e batia a cabeça deles numa pedra), Bolinha vai crescendo e aos poucos é deixado de lado pelas crianças. O dono, que não suportava mais cães, começa a maltratá-lo e ele aprende a ser mau também:

Bolinha, distraído com suas furiosas brincadeiras com um novelo de lã ou com alguma pantufa, com um chute que o mandava rolando de um lado a outro da cozinha, erguia-se depressa sobre as duas patinhas dianteiras, as orelhas levantadas, a cabeça de lado, e ficava olhando durante algum tempo.

Não gania nem protestava.

Parecia que pouco a pouco se convencesse de que os cães devem ser tratados assim; que esta fosse uma condição inerente à sua existência canina e que por isso não deveria ser levada a mal.

[...] Então, também aprendeu a se esquivar dos chutes: assim que papai Colombo levantava o pé, largava o brinquedo e ia se enfiar debaixo da cama. Abrigado ali, aprendeu uma outra coisa: o quanto os homens são maus. Ouviu um chamado carinhoso, um convite para sair de lá com um estalar de dedos:

- Aqui, Bolinha ! Queridinho! Queridinho! Aqui, pequenino!

Esperava carícias, esperava o perdão, mas, apenas agarrado pelo cangote, levou trompaços de tirar o pelo. Ah, sim? Então, ele também se tornou mau: roubou, estraçalhou, sujou, chegou até a morder. ${ }^{131}$

\footnotetext{
131 “Pallino, distratto dai suoi giuochi furibondi con un gomitolo o con qualche pantofola da una pedata che lo mandava a ruzzolare da un capo all'altro della cucina, si levava lesto lesto su le due zampette davanti, le orecchie dritte, la testa da un lato, e stava un pezzo a guardare. / Non guaiva né protestava. / Pareva che a poco a poco si capacitasse che i cani debbano esser trattati così; che questa fosse una condizione inerente alla sua esistenza canina e che non ci fosse perciò da aversene a male. / [...] Allora imparò anche a cansar le pedate: appena babbo Colo mbo alzava il piede, lasciava la preda e andava a cacciarsi sotto il letto. Lì riparato, imparò un'altra cosa: quanto, cioè, g li uo min i siano cattivi. Si sentì chiamare a morevolmente, invitare a venir fuori col frullo delle dita: / - Qua, Pallino! Caro! caro! qua, piccinino! S'aspettava carezze, s'aspettava il perdono, ma, appena ghermito per la cuticagna, botte da levare il pelo. Ah sì? E allora, anche lui si buttò alle cattive: rubò,
} 
Expulso de casa, Bolinha vaga sem rumo pela cidade até ser acolhido pelo açougueiro Fanfulla, filho bastardo de um nobre que recebera uma pequena herança ao completar dezesseis anos e abrira um açougue. Tanto Bolinha como Fanfulla são desdenhados pala família, mas a condição do açougueiro é mais crítica, porque ele

amava os animais e the cabia matá-los; não podia suportar os homens e the tocava servi-los e respeitá-los. Gostaria de ajudar os pobres; mas, como açougueiro, não podia, porque a carne para os pobres, como se sabe, é indigesta. ${ }^{132}$

Nesses trechos já surgem duas relações especulares, o aprendizado de Bolinha a ser mau com seu dono, o que também pode sinalizar uma revolta de Pirandello contra os maus tratos para com os animais, e a situação dos menos favorecidos, alijados da sociedade como Bolinha e o açougueiro.

O açougueiro conversa muito com o cãozinho, pretende torná-lo sábio e incutir-lhe caráter. Interessante notar o processo de reescrita e autocitação de Pirandello, pois numa das "lições" do açougueiro ao cãozinho, que rebatizou como Bistequinha, há o seguinte trecho: "Se você fosse porco, Bistequinha, você comeria? Eu não. O porco acredita que come para si e engorda para os outros. Não é nada bonita a sorte do porco. Ah - eu diria -, vocês me criam para isso? Obrigado, senhores. Comam-me magro." 133 Esse trecho, com pequenas modificações é o mote da novela "O Senhor dos Navegantes" (1916), que deu origem ao ato único Festa do Senhor dos Navegantes (1924).

stracciò, insudiciò, arrivò finanche a morsicare." PIRANDELLO, Luigi. "Pallino e Mimì". Referência: ver Anexo B.

132 “a mava le bestie, e gli toccava ammazzarle; non poteva soffrire gli uo mini e gli toccava servirli e rispettarli. Avrebbe tenuto in cuor suo dalla parte dei poveri; ma, da macellajo, non poteva, perché la carne ai poveri, si sa, riesce indigesta." Idem.

133 "Se fossi porco, Bistecchino, mangeresti tu? Io no. Il porco crede di mangiare per sé e ingrassa per gli altri. Non è punto bella la sorte del porco. Ah - io direi - m'allevate per questo? Ringrazio, signori. Mangiatemi magro." Idem. 
Bolinha torna-se um cãozinho solitário, esquivo e dissimulado, "era um cão sério, não dava confiança a ninguém"134 e sentia um "profundo desprezo pelos cães de sua cidade, tanto machos quanto fêmeas" 135 , assim como seu dono, exceto quando chegava a temporada e os turistas chegavam com seus cães, enchendo os hotéis da cidade, para se tratar nas Termas de Acqua Santa. ${ }^{136}$ Aí Bolinha se transformava num cão sociável, brincalhão e passava

todo o dia andando de uma Pensão à outra, para deixar, à sua maneira, levantando uma perna, cartões de visita, as boas vindas aos cães forasteiros, aos hóspedes, que depois acompanhava por todas as partes e, se necessário, defendia com feroz zelo das agressões dos conterrâneos. ${ }^{137}$

Certo dia, chega à cidade Mimi, "um amor de cachorrinha, pequena como um palmo, um floquinho branco des grenhado, em que não era possível saber onde estavam as patas, onde as orelhas" ${ }^{138}$, acompanhante de miss Galley, "uma senhorita americana, já um pouco avançada em anos, há muitos tempo morando na Itália - à procura de um marido. [...] Feia não era: alta de estatura, elegante e também formosa; belos olhos, belos cabelos, lábios um pouco entumecidos, intensos, em todo o corpo e no rosto um ar de nobreza e uma certa graça melancólica."139

Assim como Bolinha espelha o comportamento de seu dono, o açougueiro, que também se torna sociável com a chegada dos forasteiros, Mimi espelha o comportamento de

\footnotetext{
134 “era un cane serio, non dava confidenza a nessuno.” Idem.

135 "profondo disprezzo dei cani del suo paese, tanto maschi che femmine". Idem.

${ }^{136}$ A novela se passa em Chianciano Terme, estância turística próxima a Montepulciano, onde Pirandello costumava passar temporadas.

137 “tutto il giorno in giro da questa a quella Pensione, a lasciare a suo modo, alzando un'anca, biglietti da visita, il benvenuto ai cani forestieri, agli ospiti, che poi accompagnava da per tutto e, al bisogno, difendeva con feroce zelo dalle aggres sioni dei paesani." PIRANDELLO, Luigi. "Pallino e Mimì”. Referência: ver Anexo B.

138 "un amor di canina, piccola quanto un pugno, un batuffoletto bianco arruffato, che non si sapeva dove avesse le zampe, dove le orecchie." Idem.

139 “una signorina americana, ormai un po' attempatella, da parecchi anni dimorante in Italia - in cerca d'un marito. [...] Brutta non era: alta di statura, svelta e anche formosa; begli occhi, bei capelli, labbra un po' tumide, accese, e in tutto il corpo e nel volto un'aria di nobiltà e una certa grazia malinconica.” Ibidem.
} 
miss Galley. Miss Galley não consegue casamento porque não tem dote, não é rica ${ }^{140}$, e quando Mimi conhece Bolinha, torna-se quase sua rival, descarregando nela sua inveja e ciúmes, querendo que a cachorrinha permaneça "solteirona", como ela. Mas "essa cruel vigilância fazia-se menos rigorosa toda vez que um novo cortejador vinha renovar as esperanças de miss Galley." 141

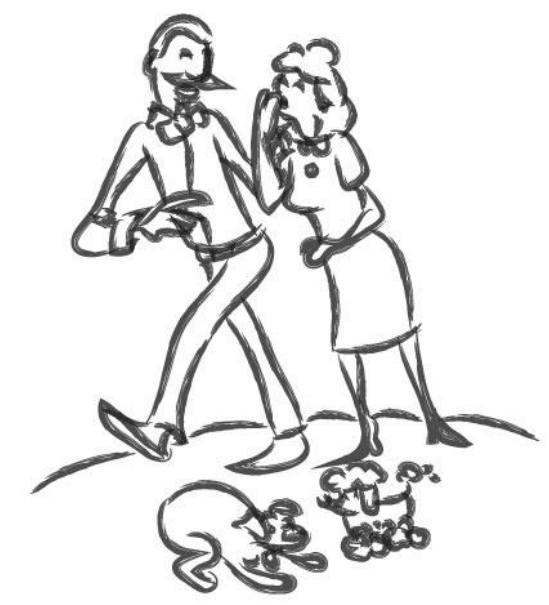

Quando miss Galley conhece, na mesma pensão em que está hospedada, o comendador Basilio Gori, "um belo homem de mais de quarenta anos, muito moreno, precocemente grisalho, mas com os bigodes ainda negros (talvez um pouco demais), elegantíssimo, o qual viera a Chianciano para uma quinzena de banhos" ${ }^{142}$, que passa a cortejá-la, deixa espaço para que Bolinha corteje Mimi.

A relação de miss Galley com Basilio Gori é perfeitamente espelhada na relação entre Bolinha e Mimi, e quando Gori deixa repentinamente a cidade, sem uma causa aparente e

\footnotetext{
${ }^{140}$ Aqui Pirandello aproveita para, ironicamente, mostrar a imagem que os italianos médios têm dos americanos: “mas miss Galley nem era ao menos rica. E então... então porque era americana?" [ma ricca miss Galley non era neppure. E allora... allora perché era americana?]. Idem.

141 “questa crudele sorveglianza si faceva men rigorosa ogni qual volta un nuovo corteggiatore veniva a rinverdir le speranze di miss Galley." Idem.

142 “un bell'uo mo d'oltre quarant'anni, molto bruno, precocemente canuto, ma coi baffi ancor neri (forse un po' troppo), elegantissimo, il quale, era venuto a Chianciano pei quindici giorni della cura." Idem.
} 
causando perplexidade em seus habitantes e turistas, Pirandello desloca a ação para os animais esclarecendo o que acontecera:

Mas de repente, por trás da pequena Arena que surge no meio da praça, elevou-se um furioso ladrar de um bando de cães brigando, embaralhados numa refrega feroz. Todos se voltaram para olhar, alguns se encolhiam de medo, outros acudiam com bastões levantados.

No meio daquela confusão estava Bolinha com a sua Mimi, Bolinha e Mimi que, em meio à inveja e ao ciúme terrível de seus companheiros, conseguiram finalmente celebrar suas núpcias. ${ }^{143}$

A algaravia de cães na praça enquanto Bolinha e Mimi celebram as "núpcias", revela o que acontecera entre miss Galley e Gori, em meio à maledicência e especulações dos banhistas, e quando Gori abandona a cidade, depois de ter conseguido seu intento, miss Galley, desesperada também abandona Mimi, envergonhada do comportamento da cachorrinha, mas muito mais envergonhada por ter cedido a Gori. O estado de espírito de miss Galley é retratado pelo comportamento de Mimi, ao ser escorraçada pela dona:

Mimi, por causa do furioso ataque, caiu no chão, bateu o focinho e, com ganidos agudos, correu mancando para se enfiar debaixo de um sofá com altura de apenas três dedos do solo, enquanto sua dona enfurecida montava na caleça e gritava ao cocheiro:

- Vamos!

Ronchi, os camareiros, os banhistas que voltaram correndo para a Pensão, ficaram algum tempo a olhar uns aos outros, atordoados; depois tiveram pena da pobre cachorrinha abandonada; mas, por mais que a chamassem e a convidassem das maneiras mais afetuosas, não houve jeito de fazê-la sair daquele esconderijo. Foi preciso que Ronchi, ajudado por um camareiro, levantasse e afastasse o sofá. Então Mimi arrojou-se pela porta como uma

\footnotetext{
143 "Ma all'imp rovviso, dietro la piccola Arena che sorge in mezzo alla piazza si levò un furibondo abbaio d'una frotta di cani azzu ffati, aggrovigliati in una mischia feroce. Tutti si voltarono a guardare, alcuni ritraendosi per paura, altri accorrendo coi bastoni levati. / In mezzo a quel groviglio c'era Pallino con la sua Mimi, Pallino e Mimi che, tra l'invidia e la gelosia terribile dei loro compagni, erano riusciti finalmente a celebrare le loro nozze." Idem.
} 
flecha e fugiu. Os moleques correram atrás dela, andaram por toda a cidade, por todos os cantos, foram até a estação: não conseguiram encontrá-la. ${ }^{144}$

Dias depois, Mimi reaparece na cidade já vazia por causa do final da temporada de verão, "tinha fome, estava cansada, tremia de frio, e não sabia mais aonde ir, aonde se refugiar" ${ }^{145}$ mas ninguém sente pena dela. Estava grávida e provavelmente miss Galley também o estivesse. O único a se compadecer dela é o açougueiro Fanfulla Mochi:

Fanfulla Mochi, da porta de seu açougue, vendo-a trotar pela rua, perdida, um dia a chamou; deu-lhe de comer; e como o pobre animalzinho, já acostumado a ser escorraçada por todos, estava com as costas arcada de medo, como que esperando algum pontapé, afagou-a, acariciou-a para acalmá-la. A pobre Mimi, apesar de faminta, parou de comer para lamber a mão de seu benfeitor. Então Fanfulla chamou Bolinha, que dormia debaixo do balcão:

- Cão, filho de um cão, feio libertino sem rabo, olhe aqui sua noiva!

Mas Mimi não era mais uma cachorrinha senhorita, havia se tornado uma cadela de rua, uma das tantas da cidade. E Bolinha nem se dignou a olhála. ${ }^{146}$

Da mesma forma que Gori, como muitas vezes fazem os sedutores, abandona miss Galley, que agora é uma "cadela de rua, uma das tantas da cidade", também Bolinha abandona Mimi, e pelo mesmo motivo.

\footnotetext{
144 "Mimì, all'urto furioso, cadde a terra, batté il musetto e, con acuti guaiti, corse ranca ranca a ficcarsi sotto un divano alto appena tre dita dal suolo, mentre la padrona inviperita montava sul legno e gridava al vetturino: / Via! / Il Ronchi, i camerieri, i bagnanti rientrati di corsa alla Pensione, restarono un pezzo a guardarsi tra loro, sbalorditi; poi ebbero pietà della povera cagnolina abbandonata; ma, per quanto la chiamassero e la invitassero coi modi piú affettuosi, non ci fu verso di farla uscire da quel nascondiglio. Bisognò che il Ronchi, ajutato da un cameriere, sollevasse e scostasse il divano. Ma allora Mimì s'avventò alla porta come una freccia e prese la fuga. I monelli le corsero dietro, girarono tutto il paese, per ogni verso, arrivarono fin presso la stazione: non la poterono rintracciare." Idem.

145 "aveva fame, era stanca, tremava di freddo, e non sapeva piú dove andare, dove rifugiarsi." Idem.

146 "Fanfulla Mochi, dalla soglia della bottega, vedendola trotterellar per via, sperduta, un giorno la chiamò; le diede da mangiare; e siccome la povera bestiola, ormai avvezza a vedersi scacciata da tutti, se ne stava con la schiena arcuata, per paura, come in attesa di qualche calcio, la lisciò, la carezzò, per rassicurarla. La povera Mimì, quantunque affamata, lasciò di mangiare per leccar la mano al benefattore. Allora Fanfulla chiamò Pallino, che dormiva nella cuccia sotto il banco: / - Cane, figlio di cane, brutto libert ino scodato, guarda qua la tua sposa! / Ma ormai Mimì non era piú una cagnetta signorina, era divenuta una cagnetta di strada, una de lle tante del paese. E Pallino non la degnò nemmeno d'uno sguardo." Idem.
} 
O que a princípio parece um "drama burguês", como outros tantos da Itália no início do século XX, mais aparentado com os dramas de Verga ${ }^{147}$, é a representação do mesmo drama em mundos paralelos - o dos humanos e o dos animais -, mas não mutuamente excludentes, sobretudo porque o mundo dos animais, neste caso, é completamente condicionado pelo mundo humano, já que se trata de animais "domésticos". A conjugação do espelhamento possível desses mundos leva o drama para o âmbito do humorismo acentuando a "percepção do contrário" e, consequentemente, levando ao "sentimento do contrário". Assim, o leitor ao ficar penalizado com a situação de Mimi passa a enxergar melhor o sofrimento de miss Galley ${ }^{148}$ e seus anseios, é levado a deixar de lado e até rever alguns preconceitos sociais (na época seguramente muito maiores do que hoje em dia) para se fixar na "pena de viver" a que ele próprio está submetido. A identificação com o animal, pelo fato dele possuir algumas características simbólicas, é mais fácil do que a identificação com outro homem. Esta novela, sem os cãezinhos, poderia ser mais um drama verista, mas o espelhamento nos animais dá o tom humorista.

O espelhamento também aparece na rivalidade entre duas mulheres do povo, que é o tema da novela “A libertação do rei” (1914), na qual Pirandello reflete, mais uma vez, o mundo dos homens (mulheres, no caso) no dos animais.

Num "beco imundo e íngreme" 149 vivem as vizinhas Tuzza Michis, solteirona que pela feiura não conseguira arranjar marido, e Mangiamariti ${ }^{150}$, que cria soltas dez galinhas, que lhe

\footnotetext{
${ }^{147}$ Ver, por exemplo, Storia di uma capinera [História de uma toutinegra] ou mes mo Una peccatrice [Uma pecadora].

${ }^{148}$ Quem sabe mais uma "velha senhora", como tantas em Pirandello.

149 “lercio vicolo scosceso.” PIRANDELLO, Luigi. "La liberazione del re”. Referência: ver Anexo B.

${ }^{150} \mathrm{O}$ nome [Come maridos], claramente transparente, poderia ser um apelido, mas do texto não surgem elementos para confirma-lo. MARZANO, Pasquale. Quando il nome è cosa "seria". L'onomastica nelle novelle di Luigi Pirandello. Pisa: Edizioni ETS, 2008, p. 443.
} 
dão religiosamente dez ovos por dia, e um "velho galo preto, pequeno e despenado"151 pelo qual tem grande afeição, como se ele fosse um marido ou amante.

Có, có, có... píu, píu, píu... có, có, có...

A Mangiamariti, como de costume, assim que acabava de dizer uma das suas, punha-se chamar assim as galinhas.

Todas elas, de pés amarelos, atendiam ao seu chamado cacarejando. Mas ela não se importava com as galinhas; esperava o velho galo preto, pequeno e despenado, que acudia por último. Sentada na soleira da porta, estendia-lhe os braços gritando:

- Querido! Amor da mamãe! Venha, querido, venha!

E como o galo lhe saltasse no colo tremendo e batendo as asas, começava a afagá-lo, beijá-lo na crista, ou o agarrava com dois dedos e lhe sacudia amorosamente as lânguidas barbelas, repetindo entre beijos e carícias:

- Meu lindo! Lindo da mamãe! Sangue do meu coração! Meu amor! ${ }^{152}$

A vizinha Tuzza Michis, apesar de estar melhor de vida do que os moradores do vilarejo, recusa-se a comprar os ovos porque a Mangiamariti não alimenta os animais, deixando que eles comam o esterco deixado na rua pelos asnos e mulas que passam. Pirandello, não sem ironia, comenta: "A vida é uma cadeia. O que uns botam fora digerido, serve a outros que estão em jejum. [...] Santa economia da natureza!"153

Tuzza Michis não é benquista na vizinhança e provoca as vizinhas fazendo comidas "que enchiam de deliciosos odores todos os barracos do beco, amarelos de fome"154. Para fazer maior despeito, Tuzza Michis compra um belo galo para engordar e comer no Natal. O

\footnotetext{
151 “vecchio gallo nero, piccolo e spennacchiato.” PIRANDELLO, Luigi. "La liberazione del re”. Referência: ver Anexo B.

152 “Co co co,... pío pío pío,... co co co... / La Mangiamariti, al solito, appena finito di dirne qualcuna delle sue, si metteva a chiamare cosí le galline. / Tutt'e dieci, queste, calzate di giallo, accorrevano crocchiando al richiamo. Ma ella non badava alle galline; aspettava il vecchio gallo nero, piccolo e spennacchiato, che accorreva per ultimo. Seduta sull'uscio, gli tendeva le braccia gridando: / - Caro! Amore di mamma! Vieni, caro, vieni! / E come il gallo le saltava in grembo fremendo e starnazzando, prendeva a lisciarlo, a baciarlo su la cresta, o gli afferrava con due dita e gli scoteva amorosamente i languidi barg igli, ripetendo tra i baci e le carezze: / - Bello mio! Bello di mamma! Sangue del mio cuore! Amore mio!” Idem.

153 "La vita è una catena. Quel che gli uni buttano via digerito, serve agli altri, che son digiuni. [...] Santa economia della natura!" Idem.

154 "che riempivano di deliziosi odori tutte le catapecchie del vicolo gialle di fame." Idem.
} 
galo, apelidado de Cocó, antes de pertencer à Michis, vivia num galinheiro rodeado de galinhas, onde se considerava um rei. Agora, sozinho no apertado e sujo quintal que sua dona chama de jardim, sente-se um prisioneiro. Além disso, ao contrário do galinho da Mangiamariti, despreza sua dona:

- Bravo, canta, Cocó! - gritava-lhe alto, quando ele cantava, quase como se cantara para irritar as vizinhas. E: - Coma, Cocó! - quando the dava de comer; - Beba, Cocó! - quando de beber; e ainda, de hora em hora: - Aqui, Cocó, venha aqui! Muito bem, Cocó!

E o galo, surdo. Comia, bebia, cantava, quando queria; depois, além de não atender ao chamado, nem se voltava. Desdenhava aquela patroa escura como um tição, com olhos ovalados e uma boca que parecia a fenda de um balcão de taverna; desdenhava aquele apelido familiar; desdenhava aquele imundo e úmido quintalzinho, onde ela o relegara. ${ }^{155}$

Os dois galos, assim, refletem alegoricamente, e até por contraste, os sentimentos e a vida de suas donas: o galo da Michis é altivo, soberbo e solitário como a dona; o galo da Mangiamariti é pequeno, mal nutrido e feio, mas é amado e tem o apoio da comunidade.

Uma vez estabelecida a relação entre as vizinhas, Pirandello desloca a ação para o mundo paralelo do galinheiro descrevendo com precisão o comportamento dos animais. Notese que a gestualidade, o comportamento e as características físicas das aves são perfeitamente respeitados pelo autor, mas os sentimentos neles embutidos são antropomorfizados sem, no entanto, ir além das limitações anatômico-biológicas dos animais. O animal pirandelliano desta fase está completamente de acordo com o animal descrito por Darwin em A expressão das emoções no homem e nos animais, o que garante a verossimilhança e reforça, mais uma vez, o espelhamento desses mundos paralelos.

\footnotetext{
155 “- Bravo, canta, Cocò! - g li diceva forte, quando esso cantava, quasi avesse cantato per far rabbia alle vicine. E: - Mangia, Cocò! - quando gli recava da mangiare; - Bevi, Cocò! - quando da bere; e poi d'ora in ora: Qua, Cocò, vieni qua! bello, Cocò! / Ma il gallo, sordo. Mangiava, beveva, cantava, quando doveva; poi, non che accorrere al richiamo, neppur si voltava. Sdegnava quella padrona nera come un tizzo, dagli occhi ovati e dalla bocca che pareva la buchetta d'un banco di taverna; sdegnava quel nomignolo confidenziale; sdegnava quel sozzo umido cortiletto, ove colei lo aveva relegato." Idem.
} 
A chegada do novo galo causa um alvoroço no terreiro da Mangiamariti, uma das galinhas consegue abrir uma passagem no muro de separação e o galo sente retornar seu reinado:

Ele então, todo vaidoso e empertigado, exibiu-se para ela de frente e de um lado, e depois do outro lado e por trás, como para se fazer admirar completamente; por fim, levantou uma pata num gesto imperativo e ficou ereto sobre a outra por um tempo; depois, sacudindo-se todo, foi ao seu encontro impetuosamente. ${ }^{156}$

Logo todas as aves passam para o pátio da Michis atiçando o ciúme do velho galo despenado da Mangiamariti e a rivalidade das mulheres.

Mas naquele instante, elevou-se no beco o canto rouco, cansado, estrangulado da ira do pequeno e velho galo preto despenado da Mangiamariti, de quem aquela franguinha primeiramente e depois as outras galinhas tinham escapado furtivamente pelo buraco do quintalzinho. [...] Quando a Mangiamariti e dona Tuzza Michis, vociferando cada vez mais alto, desceram ao quintalzinho, todas as galinhas já tinham fugido, exceto uma: a franguinha pintadinha de branco e preto. ${ }^{157}$

A discussão entre as vizinhas se acentua e após uma nova tentativa de entrada das galinhas no pátio, Tuzza Michis decide prender o galo dentro de casa durante a noite. Mas ao amanhecer, os dois galos conseguem se encontrar e inicia-se um duelo de morte.

\footnotetext{
156 “Eg li allora, tutto tronfio e impettito, le si mostrò di fronte e poi da un lato e poi dall'altro e di dietro, come per farsi ammirare da ogni parte; levò infine una zampa in atto d'impero e si tenne ritto sull'altra un pezzo; poi, scrollandosi tutto, le mosse con impeto incontro." Idem.

157 "Ma in quel punto si levò dal vicolo il canto rauco, stento, strozzato dall'ira del piccolo vecchio gallo nero spennacchiato della Mangiamariti, a cui quella pollastrotta prima e poi quelle altre galline erano sfuggite di furto per la buca del cortiletto. / Quando la Mangiamariti e donna Tuzza Michis, vociando sempre piú forte, sces ero giú nel cortiletto, erano scappate tutte, tranne una: la pollastrotta picchiettata bianca e nera." Idem.
} 


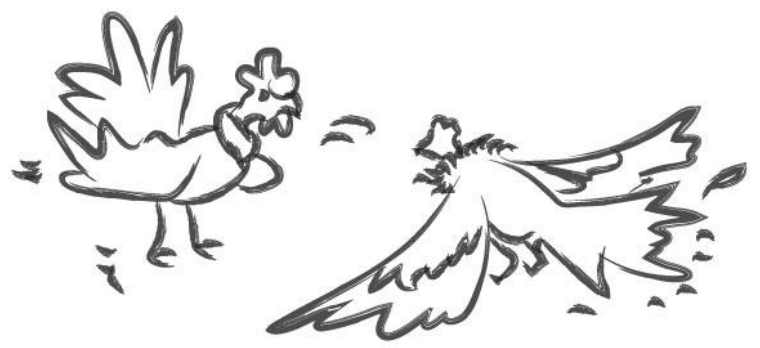

Ninguém assistiu ao feroz duelo, lá no vestíbulo escuro. Nenhuma das galinhas, nem mesmo a atrevida franguinha se arriscou a entrar, aliás, todas se puseram a cacarejar como endiabradas. Acordou a Michis, acordou a Mangiamariti, acordou toda a vizinhança. Mas, quando acudiram, o duelo já tinha acabado: o pequeno e velho galo preto jazia morto no chão, com um olho arrancado e a cabeça sangrando. ${ }^{158}$

Ao ver seu amado galo morto, a Mangiamariti, apoiada pelas vizinhas, também duela com a Michis obrigando-a a entregar seu galo como compensação:

Atacada, vencida pelas vizinhas, dona Tuzza Michis, ao final, precisou ceder.

E assim, entre o aplauso alegre das comadres da vizinhança, ao nascer do sol, com o séquito das galinhas libertadoras, todas em júbilo, tendo à frente a franguinha branca e preta, o jovem rei libertado saiu da casa da Michis em triunfo. ${ }^{159}$

\footnotetext{
158 “Nessuno assistette al feroce duello, là nell'andito bujo. Nessuna delle galline, neanche l'ard ita pollastrotta s'arrischiò a entrare, tutte anzi presero a schiamazzare come indiavolate. Si svegliò la Michis, si svegliò la Mangiamariti, si svegliò tutto il vicinato. Ma, quando accorsero, il duello era già finito: il piccolo vecchio gallo nero giaceva a terra morto, con un occhio strappato e la testa sanguinante." Idem.

159 "Assalita, sopraffatta dalle vicine, donna Tuzza Michis alla fine dovette cedere. / E cosí, tra il plauso giocondo delle comari del vicinato, sorgendo il sole, con la scorta delle gallinelle liberatrici, tutte festanti, in testa la pollastrotta bianca e nera, il giovine re liberato uscí dalla casa della Michis in trionfo." Idem.
} 
O espelhamento e a antropomorfização chegam ao máximo no duelo que acontece ao amanhecer, como em todo duelo de honra. Além disso, a briga de galos é um divertimento, ou um jogo de apostas, tradicional em algumas culturas, como a siciliana.

O ódio e a disputa entre as vizinhas são transferidos para a ação dos galos, a resolução da disputa é aplaudida pelo coro das vizinhas e pelo coro das galinhas e o galo vencedor, agora realmente sentindo-se um rei liberto, reflete a sensação de vitória da Mangiamariti sobre a Michis.

O mundo das classes baixas sicilianas pode, neste caso, ser comparado ao dia a dia desse galinheiro metafórico, que obriga as pessoas a se alimentarem dos restos deixados pelos outros e onde o ódio pelas classes mais altas é acirrado como num duelo de morte. 
b) o animal e o humano

A relação direta entre a "bestialidade" humana e a "civilidade" dos animais também está representada nas novelas. A contraposição do mundo humano e do mundo, digamos, ahumano, dos animais, é mais uma das formas que Pirandello utiliza para prospectar a realidade, para tentar identificar as causas da infelicidade e do sofrimento social a que está sujeita a humanidade, pois "a natureza talvez nem saiba que existimos" ignora quase tudo da própria realidade, é separado ainda mais irremediavelmente de outras realidades, do cosmos e em particular da natureza no meio da qual vive". ${ }^{161}$

Mais do que a "animalesca filosofia" das fábulas, essas novelas reúnem o pensamento pirandelliano, esparso por sua obra, sobre aquilo que os homens podem aprender observando a natureza e os animais, mas sempre em tom humorista e com fortes tintas críticas. Em se tratando de filosofia, é bom reiterar que, apesar de alguns críticos e intérpretes da obra do escritor considerarem-no um escritor-filósofo, ele não é e nem pretende ser filósofo. Não existe uma filosofia pirandelliana, o que existe é uma profunda vontade de compreender o animal humano, como o próprio Pirandello declarou em entrevista concedida, quando de sua temporada teatral no Brasil, a Sergio Buarque de Holanda:

Não sou um filósofo nem pretendo ser. Se minha obra exprime, como querem, uma concepção filosófica, essa concepção independe inteiramente de qualquer intenção consciente. Também não sei, nem me interessa saber qual seja essa intenção. Sustento que uma obra de arte não pode ser intencional e limito-me a interpretar a vida como ela me aparece e o mais

\footnotetext{
160 "la natura forse non sa neppure che noi esistiamo." PIRANDELLO, Luigi. "La patente". Referência: ver Anexo B.

161 “car l'homme, s'il ignore presque tout de sa propre réalité, est coupé encore plus irrémédiablement, s'il se peut, des autres réalités, du cosmos et en particulier de la nature au milieu de laquelle il vit." PERROUD, Robert. "Le bestiaire pirandellien: miroir renversé du destin humain" [O bestiário pirandelliano: espelho invertido do destino humano]. In "Revue des etudes italiennes", n 3-4, Paris: M. Didier, 1997, p. 269.
} 
diretamente possível. E não se vive com os olhos abertos, vive-se cegamente. A minha convicção de que a personalidade é múltipla não é uma conclusão - é uma constatação. ${ }^{162}$

Talvez a novela mais representativa da contraposição homem/animal seja "O Senhor dos Navegantes" (1916), mais tarde, como já mencionado, adaptada para o teatro no ato único Festa do Senhor dos Navegantes (1924). Sobre a peça, afirma Pirandello em entrevista a “L’Impero" em 11 de novembro de 1924: “A Festa do Senhor dos Navegantes é um afresco violentíssimo, no qual pretendi representar o que há de trágico na bestialidade humana; é a representação do pecado e da penitência desse rebanho humano que tem em si algo de bestial!"163

O rebanho humano, ao qual se refere Pirandello, é representado na tradicional festa siciliana do Senhor dos Navegantes, protetor dos náufragos. A festa da igreja de San Nicola, na região de Agrigento, próxima ao Vale dos Templos, tem como característica a degola e o consumo de porcos e produtos a estes relacionados.

Realmente, não sei que relação exista entre o Senhor dos Navegantes e a matança dos porcos que se costuma iniciar no dia da festa. Penso que, como no verão a carne desses anima is é nociva, tanto que se proíbe o abate, e com o outono o tempo começa a refrescar, aproveite-se a ocasião da festa do Senhor dos Navegantes, que cai exatamente em setembro, para também festejar, como se costuma dizer, as núpcias deste animal. No interior, pois o Senhor dos Navegantes se festeja na antiga igrejinha normanda de San Nicola, que se ergue a uma boa distância da cidade, numa curva da estrada, entre os campos. ${ }^{164}$

\footnotetext{
${ }^{162}$ Entrevista publicada em "O Jornal”, do Rio de Janeiro, em 11 de dezembro de 1927. Republicada no jornal "O Estado de São Paulo", em 31/12/1988.

163 "La Sagra del Signore della Nave è un affresco vio lentissimo nel quale ho voluto rappresentare quanto c'è di tragico nella bestialità u mana; è la rappresentazione del peccato e della peniten za di questo armento umano che ha in sé qualcosa di bestiale!” GIUDICE, Gaspare. Luigi Pirandello. Ro ma: UTET, 1980, p. 467 e também em ORSINI, François. Pirandello el'Europa. Cosenza: Pellegrini Editore, 2001, p.152.

164 "Veramente non so che relazione ci sia tra il Signore della Nave e la scanna dei porci che si suole iniziare il giorno della sua festa. Penso che, siccome d'estate la carne di queste bestie è nociva, tanto che se ne proibisce la macellazione, e con l'autunno il tempo comincia a rinfrescare, si colga l'occasione della festa del Signore della Nave, che cade appunto in settembre, per festeggiare anche, come suol dirsi, le nozze di quel'animale. In
} 
O narrador anônimo da novela dirige-se diretamente ao leitor, relatando inicialmente uma discussão que tivera alguns dias antes com o senhor Lavaccara ${ }^{165}$, porque ele afirmara ter um porco inteligente.

A técnica de Pirandello, de se dirigir diretamente ao leitor, é um procedimento bastante comum nas novelas, sobretudo quando o autor pretende propor uma ideia, argumentar e fazer com que o leitor acompanhe suas reflexões ${ }^{166}$. Essas novelas, em geral, são as mais marcadamente humoristas.

A discussão gira em torno da presumida inteligência do porco do senhor Lavaccara:

O senhor Lavaccara resolveu me falar de um seu porco, para me convencer que era um bicho inteligente.

Então lhe perguntei:

- Desculpe, é magro? [...]

Respondeu-me:

- Magro? Deve pesar mais de cem quilos!

Então eu the disse:

- Desculpe, o senhor acha que ele possa ser inteligente?

Falava-se do porco. O senhor Lavaccara, com toda aquela rósea prosperidade de carne que the tremulava em cima, acreditou que eu, depois do porco, agora quisesse ofendê-lo, como se eu tivesse dito que a gordura, geralmente, exclui a inteligência. Mas repito, falava-se do porco. De modo que o senhor Lavaccara não precisava se zangar nem me perguntar:

- Então eu, segundo o senhor?

Apressei-me em responder:

campagna, perché il Signore della Nave si festeggia nell'antica chiesetta normanna di San Nicola, che sorge un buon tratto fuori del paese, a una svolta dello stradone, tra i campi." PIRA NDELLO, Luig i. "Il Signore della Nave". Referência: ver Anexo B.

165 “O nome Lavaccara não é explicado no texto, mas é certamente notável o fato que o personagem seja designado por um zoônimo e seja tão ligado ao próprio porco. Seria possível lançar a hipótese de uma espécie de aliança imperfeita entre animais, mas também é relevante a costumeira inversão da situação aparentemente paradoxal, em que os animais se comportam como seres humanos e vice-versa." [Il nome Lavaccara non è rimotivato nel testo, ma è certamente notevole il fatto che il personaggio sia designato da uno zoonimo e sia tanto legato al proprio maiale. Si potrebbe ipotizzare una sorta di alleanza imperfetta fra bestie, ma è rimarchevole anche il solito capovolgimento della situazione apparentemente paradossale, in cui le bestie si comportano da esseri umani e viceversa.] MARZANO, Pasquale. Op. cit., p. 393.

${ }^{166}$ É o caso, por exemplo, do narrador de “A senhora Frola e o senhor Ponza, seu genro" (1917), depois transformado, no teatro, no personagem Lamberto Laudisi, de Assim é (se lhes parece) (1917). 
- O que o senhor tem a ver com isso, caro senhor Lavaccara? Por acaso o senhor é porco? Desculpe-me. Quando o senhor come, com o belo apetite que Deus the conserve sempre, para quem o senhor come? Come para si, não engorda para os outros. O porco, entretanto, acha que come para si e engorda para os outros. ${ }^{167}$

Sobre esse diálogo inicial, comenta Zangrilli: "enquanto fala do porco, na verdade está sempre falando, até com ácida ironia, de Lavaccara, ou seja, de um indivíduo emblemático de toda uma sociedade, uma civilização, uma humanidade ínfima, imunda, que perdeu o critério de vida." 168

A discussão se prolonga levando ao rompimento entre os dois que, algum tempo depois, se encontram na festa do Senhor dos Navegantes, aonde acorre uma multidão para homenagear um assustador Cristo milagroso que "nas duras canelas pregadas na rústica cruz, nas costelas que se podem contar uma a uma, entre as chagas e machucaduras, não há nem um pouco de carne que não esteja atrozmente martirizada." ${ }^{169} \mathrm{O}$ lado profano e sacrificial da festa é representado pelas varas de porcos que são levadas para o pátio da igreja onde são mortos, esquartejados e assados para serem servidos em banquete aos fiéis:

Quando, de manhã, no meio da poeira da estrada avistei grandes e pequenas varas de porcões rosados bamboleando e grunhindo em direção à festa, senti vontade de olhá-los atentamente um a um.

\footnotetext{
167 "Il signor Lavaccara mi volle parlare d'un suo porco per convincermi ch'era una bestia intelligente. / Io allora gli domandai: / - Scusi, è magro? [...] / Mi rispose: / - Magro? Peserà piú d'un quintale! / E io allora gli dissi: / - Scusi, e le pare che possa essere intelligente? / Del porco si parlava. Il signor Lavaccara, con tutta quella rosea prosperità di carne che gli tremola addosso, credette che io dopo il porco ora volessi offendere lui, co me se in genere avessi detto che la grassezza esclude l'intelligenza. Ma del porco, ripeto, si parlava. Non doveva dunque farsi cosí brutto il signor Lavaccara né domandarmi: / - Ma allora io, secondo lei? / M'affrettai a rispondergli: / - O che c'entra lei, caro signor Lavaccara? È forse un porco lei? Mi scusi. Quando lei mangia col bello appetito che Dio le conservi sempre, per chi mangia lei? mangia per sé, non ingrassa mica per gli altri. Il porco, invece, crede di mangiare per sé e ingrassa per gli altri." PIRANDELLO, Luigi. "Il Signore della Nave". Referência: ver Anexo B.

168 "mentre parla del maiale in realtà sta sempre parlando, pur con ironia acerba, di Lavaccara, ossia di un individuo emblematico di tutta una società, una civiltà, una umanità infima, immonda, che ha smarrito il criterio di vita." ZANGRILLI, Franco. Il bestiario di Pirandello. Fossombrone: Metauro Edizione, 2001, p. 131.

169 "nei duri stinchi inchiodati su la rozza croce nera, nelle costole che gli si possono contare tutte a una a una, tra i guidaleschi e le lividure, non un'oncia di carne gli lasciò che non apparisse atrocemente martoriata." PIRANDELLO, Luigi. "Il Signore della Nave". Referência: ver Anexo B.
} 
Anima is inteligentes? Que nada! Com esses grunhidos? Com essas orelhas? Com essa engraçada coisinha enrolada atrás? Grunhiriam assim, se fossem inteligentes? Esse seu grunhido é a própria voz da gula! ${ }^{170}$

Pirandello-narrador prossegue descrevendo, agora, a chegada da multidão para a festa:

Que outro aspecto, meus senhores!

O dom divino da inteligência transparecia até nas mínimas ações: no aborrecimento com que viravam o rosto para não receber a poeira levantada por aqueles bandos de animais e no respeito com que se cumprimentavam uns aos outros. [...]

E mesmo que os imaginássemos nus pela estrada, homens e mulheres; algo impossível, mas admitamos, não digo que seria um belo espetáculo, as velhas, os barrigudos, os sujos; entretanto, que diferença, pensem bem, mesmo olhando apenas à luz do olho humano, espelho da alma, o dom do sorriso e da palavra ${ }^{171}$

No paralelismo entre as duas multidões, baseada nos binômios inteligência/nãointeligência, civilidade/bestialidade, transparece a aguda observação humorista da bestialidade humana, que as características unicamente humanas, como o uso da palavra e o sorriso, podem mascarar temporariamente: "Porque um porco é porco e basta. Mas um homem, não, senhores, poderá até ser porco, não nego, mas porco e médico, por exemplo, porco e advogado, porco e professor de belas letras e filosofia, e tabelião e chanceler e relojoeiro e ferreiro..." ${ }^{\prime 12}$. Temporariamente porque, assim que a festa começa, os instintos vêm à tona e a

\footnotetext{
170 "Quando, la mattina, tra la polvere dello stradone ho veduto i branchi e branchetti di tutti quei porcelloni cretacei avviarsi ballonzolanti e grufolanti al luogo della festa, ho voluto guardarli apposta a uno a uno attentamente. / Bestie intelligenti, quelle? Ma via! Con quel grugno lí? con quelle orecchie? con quel buffo cosino arriccio lato dietro? E grugnirebbero cosí, se fossero intelligenti? Ma se è la voce della stessa ingordigia, quel loro grugnito!" Idem.

171 "Che altro aspetto, signori miei! / Il dono divino dell' intelligenza traspariva anche dai minimi atti: dal fastidio con cui voltavano la faccia per non prendersi il polverone sollevato dai branchi di quelle bestie, e dal rispetto con cui poi si salutavano l'un l'altro. [...] E quand'anche li immaginassimo nudi per lo stradone, uomini e donne; cosa impossibile, ma ammettiamo la pure; non dico che sarebbe un bel vedere, le vecchie, i panciuti, i non puliti; tuttavia, che differenza, pensate, anche a guardar soltanto alla luce dell'occhio umano, specchio dell'anima, e al dono del sorriso e della parola." Idem.

172 "Perché un porco è porco e basta; ma un uo mo, no, signori, potrà anche esser porco, non dico, ma porco e medico, per esempio, porco e avvocato, porco e professore di belle lettere e filosofia, e notajo e cancelliere e orologiajo e fabbro..." Idem.
} 
multidão humana se lança a uma orgia desenfreada de comida (porcos) e bebida (vinho). Esta orgia, esta falta passageira de razão, que faz emergir a bestialidade humana - e mais uma vez aqui podemos ouvir ressoar a risada de Perazzetti - "amanhã encontrará com um farmacêutico o purgante capaz de curá-los."

No meio da multidão, está o senhor Lavaccara "suado e transtornado, sem casaco, levando nas mãos um grande prato comprido"174, acompanhado pela esposa "rósea e próspera como ele" 175 , não menos gorda ou menos bestial do que o marido e um dos filhos, "um porquinho vestido de marinheiro."176

A crueldade para com os animais também é o alvo de Pirandello nesta novela para denunciar a bestialidade humana. $\mathrm{O}$ aspecto de imolação e sacrifício pagão, com os porcos sendo abatidos diante da multidão em festa, repugnam o narrador e a maioria dos convivas, que mesmo assim não se abstém de comer e beber em nome de um sentimento religioso.

Vi muitos empalidecerem, tapar os ouvidos com as mãos, virarem o rosto para não ver a faca entrar no pescoço do porco convulso, segurado violentamente por oito braços sanguinolentos despidos; e para dizer a verdade, também virei o rosto, mas lamentando amargamente por dentro que o homem aos poucos, com o progredir da civilização, torna-se cada vez mais fraco, perde sempre mais, mesmo buscando fortalecer o sentimento religioso. Ele continua, sim, a comer porco; assiste de bom grado a manufatura de linguiças, a lavagem das vísceras, o corte preciso do fígado reluzente, compacto e tremulante; mas depois vira o rosto no ato da imolação. E certamente já não se lembra mais da antiga Maia, mãe do deus Mercúrio, de quem o porco repete seu outro nome (maiale). ${ }^{177}$

\footnotetext{
173 “domani troverà da un farmacista la purghetta che li guarirà." Idem.

174 "sudato e stravolto, senza giacca, recando tra le mani un gran piatto bislungo." Idem.

175 "ros ea e prosperos a come lui." Idem.

176 "un majaletto vestito alla marinara." Idem.

177 "Ho visto tanti impallidire, turarsi con le mani gli orecchi, torcere il viso per non vedere l'accoratojo brandito cacciarsi nella gola del porco convulso tenuto violentemente da otto braccia sanguinose smanicate; e per dir la verità, ho torto il viso anch'io, ma lamentando dentro di me amaramente che l'uomo a mano a mano, col progredire della civiltà, si fa sempre piú debole, perde sempre piú, pur cercando d'acquistarlo meglio, il sentimento religioso. Seguita, sí, a mangiarsi il porco; volentieri assiste alla man ifattura delle salsic ce, alla lavatura della corata, al taglio netto del fegato lucido compatto tremolante; ma torce poi il viso all'atto
} 
A menção à deusa Maia ${ }^{178}$ reforça o caráter pagão da festa, Pirandello denuncia, assim, a ritualidade cristã que, em muitos casos, se baseia em costumes e deuses pagãos, como forma de recrutar adeptos.

O próprio senhor Lavaccara entrega seu porco inteligente para ser degolado em troca da cabeça e do fígado do animal.

Também dessa vez, mas com mais razão, o senhor Lavaccara fingiu não me ver. Um dos dois meninos chorava; mas quero crer que não chorasse por se aproximar o momento de ver a pálida cabeça ensanguentada daquele grande e querido animal acariciado por dois anos no quintal de casa. O pai contemplará aquela cabeça de largas orelhas caídas, de olhos gravemente entrecerrados em meio a pelos, para talvez louvar, com tristeza, mais uma vez sua inteligência, e por essa maldita obstinação perderá o prazer de comê-la. ${ }^{179}$

O senhor Lavaccara é o "digno" representante da multidão que aos poucos vai se bestializando, "sem nem ao menos uma sombra de consciência, sem a ma is remota memória dos inumeráveis méritos que, em tantos séculos, soube conquistar acima dos outros animais da terra, com seus esforços e suas virtudes." 180

A violenta crítica de Pirandello, que começara em tom de zombaria, vai aos poucos se revelando em imagens cada vez mais repulsivas, acompanhadas, propositalmente, de uma

dell'immolazione. E certo è ormai cancellato il ricordo dell'antica Maja, madre del dio Mercurio, da cui il porco ripete il suo secondo nome." Ibidem.

${ }^{178}$ Maia Maiestas é uma deusa romana para quem era sacrificada, no primeiro dia de maio, u ma porca grávida num ritual de fertilidade. Na Itália, talvez por este motivo, o porco também é chamado de "maiale".

179 "Anche questa volta, ma con piú ragione, il signor Lavaccara ha finto di non vedermi. Uno dei due piccini piangeva; ma voglio credere che non piangesse per la prossima vista della pallida testa insanguinata della cara grossa bestia carezzata per circa due anni nel cortile della casa. La conte mplerà il padre quella testa dalle larghe orecchie abbattute, dagli occhi gravemente socchiusi tra i peli, per lodarne forse, con rimpianto ancora una volta, l'intelligenza, e per questa maledetta ostinazione si guasterà il piacere di mangiarsela." PIRANDELLO, Luigi. "Signore della Nave". Referência: ver Anexo B.

180 "senza piú neppure un'ombra di coscienza, senza la piú lontana memoria delle innumerevoli benemerenze che in tanti secoli ha saputo acquistarsi sopra le altre bestie della terra con le sue fatiche e con le sue virtú." Idem. 
linguagem que tenta se manter distanciada, equilibrada, mas que é impedida pelos horrores contra a dignidade humana e dos animais.

Os homens sem camisa, as mulheres descompostas; cabeças balançando, rostos afogueados, olhos parados, danças loucas entre mesas caídas, bancos revirados, cantos vulgares, fogueiras, disparos de morteiros, gritos de crianças, risadas exageradas. Um pandemônio sob as densas e graves nuvens avermelhadas do entardecer, surgidas quase com espanto. ${ }^{181}$

Nessa festa dionisíaca, o homem vai pouco a pouco se desnudando dos valores adquiridos através dos tempos e se deixa rebaixar voluntariamente a um estado inferior ao do porco que massacra e come em nome da religião. Deixa cair a máscara que se sustenta com dificuldade e liberta a besta do seu antro.

O ápice da festa acontece quando sai da igreja o terrível Cristo crucificado e flagelado na cruz negra, massacrado e imolado como os porcos, seguido pela multidão que "chorava, chorava, [...] embriagada, soluçava, batia no peito, arrancava os cabelos desgrenhados." 182

O tom humorista retorna no final da novela, no diálogo entre o narrador e dois porcos que escaparam ao massacre, apenas para confirmar a bestialidade humana:

Dois grandes porcos, que escaparam da matança por uma sorte tremenda, deitados ao pé de uma figueira, vendo passar a procissão, pareciam olhar um ao outro como se dissessem:

- Está vendo, irmão? E depois dizem que os porcos somos nós. [...]

- Morrer degolados não é nada, ó bichos estúpidos! - exclamei triunfante. Vocês, porcos, passam gorda e em paz a sua vida, enquanto dura. Vejam a vida dos homens agora! Eles se bestializaram, se embriagaram, e agora choram inconsolavelmente, atrás desse seu Cristo sangrando numa cruz

\footnotetext{
181 "Scamiciati gli uo mini, discinte le donne; teste ciondolanti, facce paonazze, occhi imbambolati, danze folli tra tavole capovolte, panche rovesciate, canti sguajati, falò, spari di mortaretti, urli di bimbi, risa sgangherate. Un pandemonio sotto le rosse nubidense e gravi del tramonto, sopravvenute quasicon spavento." Idem. 182 "piangeva, piangeva, [...] ubriaca, singhiozzava, si dava pugni sul petto, si strappava i capelli scarmig liati." Idem.
} 
negra! Estão aqui chorando o porco que comeram! Vocês querem uma tragédia mais tragédia do que esta? ${ }^{183}$

O tema da bestialidade humana aparece em muitas outras novelas, como já foi destacado em algumas delas, mas com tons mais suaves. O quadro aqui traçado por Pirandello pode ser visualmente comparado aos trípticos do pintor holandês Hieronymus Bosch (14501516), em que muitas cenas caricaturais e grotescas, sacras e profanas se superpõem. Se Bosch tivesse usado esta novela como tema, provavelmente colocaria, de um lado a degola dos porcos, do outro a multidão ensandecida desnudando suas máscaras, e no centro o terrível Cristo flagelado abençoando ambas as multidões.

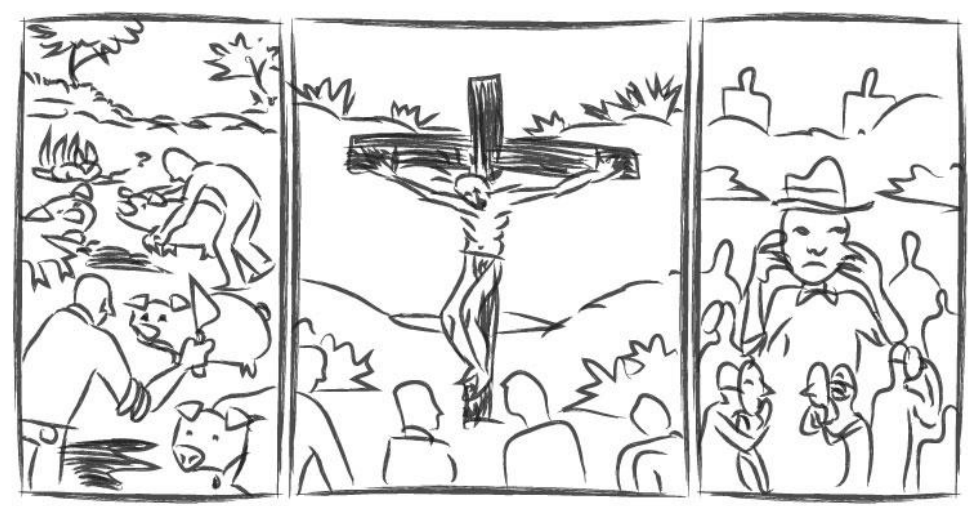

$\mathrm{O}$ conceito de bestialidade também aparece mais fugazmente e de forma menos perceptível, ou até mesmo atenuado em romances do autor. Em Ofalecido Mattia Pascal, por exemplo, o personagem Anselmo Paleari, ao tentar uma explicação para a vida, refere-se ao

\footnotetext{
183 "Due porcelloni, per loro somma ventura scampatial macello, sdrajati a piè d'un fico, vedendo passare quella processione, m’è parso si guardassero tra loro come per dirsi: / - Ecco, fratello, vedi? e poi dicono che i porci siamo noi. [...] / - Morire scannate è niente, o stupidissime bestie! - io allora esclamai, trionfante. - Voi, o porci, la passate grassa e in pace la vostra vita, finché vi dura. Guardate a questa degli uomini adesso! Si sono imbestiati, si sono ubriacati, ed eccoli qua che piangono ora inconsolabilmente, dietro a questo loro Cristo sanguinante su la croce nera! eccoli qua che piangono il porco che si sono mangiato! E volete una tragedia piú tragedia di questa?"Idem.
} 
homem como "esse animal que rouba, esse animal que mata, esse animal mentiroso, mas que no entanto é capaz de escrever a Divina Comédia"184.

"O Senhor dos Navegantes" reflete o esvaziamento de significado da religiosidade, seja ela cristã ou pagã, que, assumindo um sentido meramente convencional, descamba para irracionalidade. A mescla de religiosidade cristã e mitologia é muito forte na Sicília, e Pirandello a utiliza, mais uma vez, para sensibilizar o leitor.

Entre as convenções sociais, uma das que Pirandello analisa mais diretamente, demonstrando sua fatuidade, são as pompas fúnebres. Pelo menos em três novelas “Dis tração" (1907), "O ilustre extinto" (1909) e "A pirueta" (1913) -, Pirandello se detém em examinar os ritos sociais de passagem do homem da vida à morte.

Em "A pirueta", as extravagâncias, as crenças, os ritos e costumes necessários para "transportar" o homem desta vida para a morte, são vistos pelos olhos do "outro": os olhos de dois cavalos que puxam o carro mortuário.

Nero é um "cavalo bem educado ${ }^{185 "}$ recentemente vendido para um serviço de pompas fúnebres. Antes pertencera às estrebarias de uma velha princesa cujo filho, depois da mãe ter adoecido gravemente, se desfez dos cavalos e das carruagens. Em sua nova cocheira, Nero é preparado para seu primeiro trabalho e é instruído por um cavalo mais velho, já habituado ao serviço, mas que não compreende bem do que se trata:

Você sabe o que quer dizer pompa fúnebre? Quer dizer puxar uma carroça negra de formato curioso, alta, com quatro coluninhas que sustentam o céu, tudo adornado de franjas e paramentos e douraduras. Enfim, uma bela carroça de luxo. Mas é um desperdício, pode crer! Um grande desperdício,

\footnotetext{
184 "questa bestia che ruba, questa bestia che uccide, questa bestia bugiarda, ma che pure è capace di scrivere la Divina Commedia." PIRANDELlO, Luigi. Il fu Mattia Pascal In Tutti i romanzi, Vol. I. Milano: Arnoldo Mondadori Editore, 1973, p. 441.

185 "um cavalo bene educato." PIRANDELLO, Luigi. "La rallegrata”. Referência: ver Anexo B.
} 
porque dentro, você vai ver, nunca sobe ninguém. Só o cocheiro, muito sério, na boleia. ${ }^{186}$

Ainda confuso com sua drástica mudança de vida, Nero também não compreende onde foi parar. A cocheira conta com mais de vinte cavalos, mas "que eles também compreendessem bem o trabalho que faziam, Nero duvidava. Aliás, parecia-lhe que todos estivessem continuamente a pensar nisso, sem, todavia, descobrir. [...] certamente eram cavalos pensativos." $" 187$

Fofo, por ser o mais antigo dos cavalos em serviço, dá-se o direito de criticar os outros animais da esquadra, e tenta instruir o recém chegado sobre as "diferenças sociais" de seus companheiros, numa maledicência tipicamente humana:

De vinte, não se salvava um! Este era assim, aquele assado.

"A cauda... olhe lá, por favor, se aquilo é uma cauda! Se aquilo é jeito de mover a cauda! Que animação, hein?

"Cavalo de médico, estou the dizendo.

"E lá, lá, olhe lá aquele belo trutrú calabrês, como sacode com graça as orelhas de porco. E que belo topete! e que bela barbada! Muito elegante também, você não acha?

"De vez em quando sonha que não é castrado, e quer fazer amor com aquela égua lá, três baias à direita, está vendo? Com cabeça de velha, baixa na frente e a barriga arrastando no chão.

"Aquilo é uma égua? Aquilo é uma vaca, devo dizer. E se você visse como anda em passo de escola! Parece que seus cascos queimam ao tocar o chão." 188

\footnotetext{
186 "Po mpa funebre sai che vuol dire? Vuol dire tirare un carro nero di forma curiosa, alto, con quattro colonnini che reggono il cielo, tutto adorno di balze e paramenti e dorature. Insomma, un be l carrozzone di lusso. Ma roba sprecata, non credere! Tutta roba sprecata, perché dentro vedrai che non ci sale mai nessuno. Solo il cocchiere, serio serio, in serpe." Idem.

187 "che anch'essi comprendessero bene l'uffic io a cui erano addetti, Nero dubitava. Gli pareva che tutti quanti, anzi, stess ero di continuo a pensarci, senza tuttavia venirne a capo. [...] certo erano dei cavalli cogitabondi." Idem.

${ }^{188}$ Di venti, non se ne salvava uno! Questo era così, quello cosà. / 'La coda... guardami là, per piacere, se quella è una coda! se quello è un modo di muovere la coda! Che brio, eh? / 'Cavallo da medico, te lo dico io. / 'E là, là, guardami là quel bel truttrù calabrese, come crolla con grazia le orecchie di porco. E che bel ciuffo! e che bella barbozza! Brioso anche lui, non ti pare? / 'Ogni tanto si sogna di non esser castrone, e vuol fare all'a mo re con quella cavalla là, tre poste a destra, la vedi? con la testa di vecchia, bassa davanti e la pancia fin a terra. I
} 
Cabe também a Fofo explicar a Nero como se comportar durante o trabalho que de vem fazer, mas como ele mesmo não sabe o porquê do que faz, a novela vai adquirindo tons humoristas crescentes. A contrariedade de Nero de se encontrar ali e ter sido separado de seu antigo colega na estrebaria da princesa, Corsino, e de seu antigo cocheiro, Giuseppe, faz com que não dê ouvidos a Fofo, o que o leva a falar cada vez mais para chamar a atenção do companheiro:

Nosso serviço é leve, não há como negar; mas é preciso compostura e solenidade. Nada de bufar, nada de arfar. Já é muito que nos concedam balançar a cauda bem devagar.

Porque o carro que nós puxamos, repito, é muito respeitado. Você vai ver que todos, assim que nos veem passar, tiram o chapéu. ${ }^{189}$

A ignorância dos cavalos quanto aos rituais humanos conduz a mal-entendidos que demonstram a própria ignorância dos seres humanos sobre o sentido dos rituais. Assim, Fofo imagina que carrega "carga para expedir, certo. Mas que carga, não sei. Parece importante, porque a expedição acontece com muita pompa e grande comitiva"190, e que o local ao qual vai costumeiramente, uma grande cerca gradeada onde "por trás dela há muitas árvores escuras, pontudas, que vão muito alinhadas em duas filas intermináveis, tendo aos lados lindos prados verdes"191 é uma grande aduana: "Para onde vai toda essa carga preciosa, que

\footnotetext{
'Ma quella è una cavalla? Quella è una vacca, te lo dico io. E se sapessi come la va con passo di scuola! Pare che si scottigli zoccoli, toccando terra" Idem.

189 "Il nostro è un servizio piano, non si nega; ma vuole compostezza e solennità. Niente sbruffi, niente beccheggio. È già troppo, che ti concedano di dondolar la coda, appena appena. / Perché il carro che noi tiriamo, torno a dirtelo, è molto rispettato. Vedrai che tutti, come ci vedono passare, si levano il cappello." Idem.

190 “roba da spedire, certo. Ma che roba, non lo so. Pare di gran conto, perché la spedizione avviene con molta pompa e molto accompagnamento.” Idem.

191 "ci sono dietro tanti alberi neri, a punta, che se ne vanno dritti dritti in due file interminabili, lasciando di qua e di là certi bei prati verdi." Idem.
} 
nós expedimos [...] ainda não consegui entender. Mas duvido que os homens também entendam bem; e me consolo."192

Aos poucos, pelos comentários do cavalo Fofo, Pirandello vai construindo uma profunda crítica às convenções humanas, certamente menos terrível do que aquela de " $\mathrm{O}$ Senhor dos Navegantes", mas não menos precisa e contundente.

A voz de Fofo ${ }^{193}$ confunde-se com a voz do autor em sua ferina crítica às convenções sociais. Assim, quando o cavalo reclama dos discursos que terão de ouvir no trabalho que farão naquele dia, pois se trata de uma "expedição" de primeira classe, em que pode haver até cinco discursos, ouve-se sutilmente ao fundo a voz do narrador inconformado com o esvaziamento de sentido nesse ritual humano.

O fato de o cavalo não entender o que está fazendo realça o componente humorista na novela e leva o leitor a questionar a validade desta e de outras convenções que a sociedade impõe. Quando Fofo descreve para Nero o comportamento que deverão ter durante os discursos: "Três horas parado, com todas essas galanterias em cima, que são de tirar o fôlego: as pernas endurecidas, a cauda presa, as orelhas entre dois furos. Alegre, com as moscas lhe comendo por debaixo da cauda!"194, Pirandello descreve também o comportamento esperado dos acompanhantes do enterro. A descrição do carro mortuário remete à falsa solenidade dos acompanhantes do enterro: "aquele carro ali deve ser objeto de particular veneração para os homens $[\ldots]$ assim que começamos a nos mover, muitas pessoas o seguem caladas [...] na nossa frente vai a banda que toca uma música de dar enjoo."195

\footnotetext{
192 "Dove vada tutta questa roba preziosa, che noi spediamo [...] non sono riuscito ancora a capirlo. Ma ho un certo dubbio, che non lo capiscano bene neanche gli uomini; e mi consolo." Idem.

193 Além dos animais das fábulas, Fofo e o urso da novela "A prova" (1935), são os únicos animais falantes na obra de Pirandello.

194 "Tre ore di fermo, con tutte queste galanterie addosso che ti levano il respiro: le gambe impastoiate, la coda imprigionata, le orecchie tra due fori. Allegro, con le mosche che ti mangiano sotto la coda!" PIRANDELLO, Luigi. "La rallegrata". Referência: ver Anexo B..

195 “quel carro lì dev'essere per gli uomini oggetto di particolare venerazione [...] appena cominciamo a muoverci, tanti dietro, zitti zitti, lo accompagnano [...] davanti a noi, c'è la banda che ti suona un a certa musica, da far cascare a terra le budella." Idem.
} 
As observações de Fofo, até certo ponto cômicas, tocam em pontos nevrálgicos da sociedade e dos rituais da morte, e o leitor vai aos poucos se conscientizando da vacuidade das convenções humanas, num movimento perfeitamente humorista que leva da "percepção do contrário" ao "sentimento do contrário". A crítica social só pode acontecer através do olhar do outro, o olhar do animal que "não sabe que deve morrer".

Ao chegarem diante dos portões do palácio onde devem pegar sua "carga para expedir", Nero reconhece sua antiga moradia e parece ter enlouquecido: relincha, pateia, arqueja, treme, faz piruetas. A reação do cavalo em contraste com toda aquela solenidade escandaliza a todos, o cocheiro não conse gue controlá-lo. Só quando chega seu antigo tratador e o reconhece, tomando-o pelas rédeas, Nero consegue se acalmar:

- Mas é o Nero! É o Nero! Ah, pobre Nero, claro que faz assim! O cavalo da senhora! O cavalo da pobre princesa! Reconheceu o palácio, sente o cheiro de sua escuderia! Pobre Nero, pobre Nero... calma, calma... está vendo? Sou eu, o seu velho Giuseppe. Bonzinho, assim... Pobre Nero, cabe a você levála, está vendo? A sua patroa. Cabe a você, pobrezinho, que ainda se lembra. Ela vai ficar contente de ser transportada por você, pela última vez. ${ }^{196}$

196 “- Ma è Nero! è Nero! Ah, povero Nero, sicuro che fa così! Il cavallo della signora! il cavallo della povera principessa! Ha riconosciuto il palazzo, sente l'odore della sua scuderia! Povero Nero, povero Nero... buono, buono... sì, vedi? sono io, il tuo vecchio Giuseppe. Sta' buono, sì... Povero Nero, tocca a te di portartela, vedi? la tua padrona. Tocca a te, poverino, che ti ricordi ancora. Sarà contenta lei d'essere trasportata da te per l'ultima volta." Idem. 


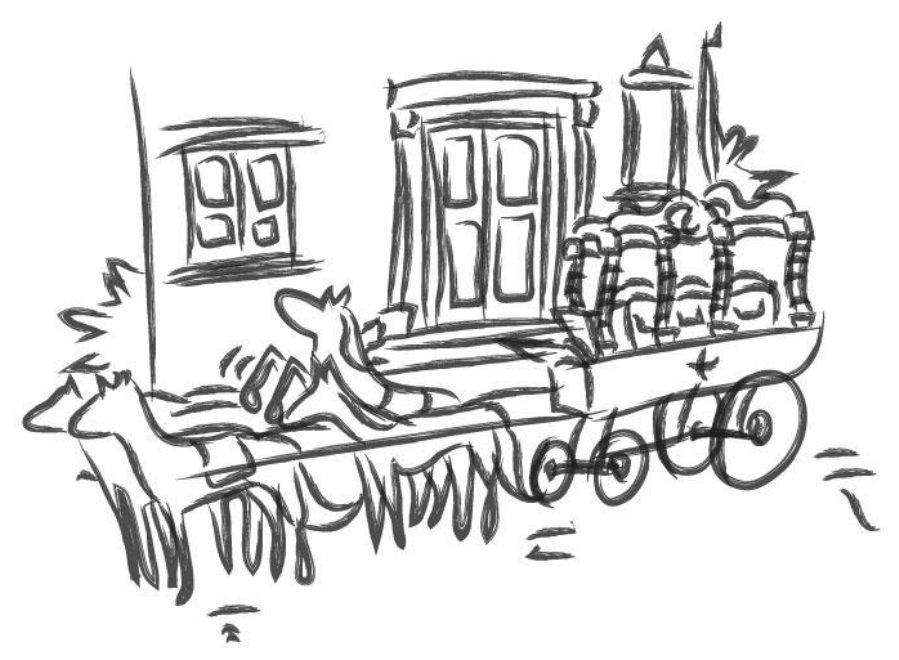

Finalmente, Fofo entende que tipo de carga eles devem expedir e, filosoficamente, exclama: “Agora entendo tudo, entendo tudo... Por isso o nosso serviço é tão leve! Somente quando os homens choram, nós podemos ficar alegres e andar devagar... ${ }^{197}$ ". E sente vontade de também fazer uma pirueta.

A valorização social da morte e seus ritos não podem ser entendidos no mundo nãohumano. Os cavalos lidam apenas com a realidade imediata, como todos os outros animais, pois não é da natureza deles a celebração da morte. $\mathrm{O}$ ar arrogante que o bem educado Nero assume diante do simplório Fofo, numa imitação do comportamento humano, retrata a hipocrisia das convenções e separações sociais que impõem ao homem máscaras fictícias e papéis fixos, e cuja compreensão vai além da capacidade dos animais. Pirandello rejeita com extrema lucidez essas diferenciações entre classes e qualquer tipo de sociedade organizada que reprima a espontaneidade e a imediatez da vida, que ao final é recuperada pela pirueta. A pirueta é o que resta ao homem desprovido de razão.

A presença da morte e seus rituais é uma constante na obra Pirandello, e talvez isso se deva a um incidente acontecido na juventude do autor. Gaspare Giudice ${ }^{198}$ comenta que, ainda

\footnotetext{
197 “Capisco tutto, adesso, capisco tutto... Per questo il nostro servizio è così piano! Solo quando gli uo mini piangono, possiamo stare allegri e andar ripos ati nojaltri..." Idem.

${ }^{198}$ GIUDICE, Gaspare. Luigi Pirandello. Torino: UTET, 1963, pp. 33-34.
} 
muito jovem, Pirandello foi até um local onde sabia que policiais haviam deixado um homem encontrado morto, pela curiosidade de saber como era um corpo sem vida. $\mathrm{O}$ local era escuro e, depois de examinar o corpo, o menino se deparou com um casal durante o ato sexual. A associação entre morte e intimidade sexual marcou profundamente Pirandello para o resto de sua vida e se reflete em muitas das novelas sobre o tema. Talvez essa conjugação de fatores tenha influenciado também suas últimas vontades, nas quais pede um funeral simples, sem acompanhamento e quase anônimo:

"Minhas últimas vontades a serem respeitadas"

I. Minha morte seja deixada passar em silêncio. Aos amigos, aos inimigos, prece, não apenas não falar aos jorna is, mas não fazer nenhuma alusão. Nem anúncios, nem participações.

II. Morto, não me vistam. Envolvam-me, nu, num lençol. E nada de flores no leito e nenhuma vela acesa.

III. Carro de ínfima classe, o dos pobres. Nu. E ninguém me acompanhe, nem parentes, nem amigos. O carro, o cavalo, o cocheiro e basta.

IV. Incinerem-me. E meu corpo, em cinzas, seja espalhado; porque nada, nem mesmo as cinzas, gostaria que sobrasse de mim. Mas se isso não for possível, a urna cinerária seja levada à Sicília e murada em alguma rústica pedra nos campos de Girgenti, onde nasci. ${ }^{199}$

\footnotetext{
199 “'Mie ultime volontà da rispettare’ / I. Sia lasciata passare in silenzio la mia morte. Agli amici, ai nemici preghiera, non che di parlarne sui giornali, ma di non farne pur cenno. Né annunzii né partecipazioni. / II. Morto, non mi si vesta. Mi s'avvolga, nudo, in un lenzuolo. E niente fiori sul letto e nessun cero acceso. / III. Carro d'infima classe, quello dei poveri. Nudo. E nessuno m'accompagni, né parenti né amici. Il carro, il cavallo, il cocchiere e basta. / IV. Bruciatemi. E il mio corpo, appena arso, sia lasciato disperdere; perché niente, neppure la cenere, vorrei avanzasse di me. Ma se questo non si può fare sia l'urna cineraria portata in Sicilia e murata in qualche rozza pietra nella campagna di Girgenti, dove nacqui." PIRANDELLO, Luigi. "Mie ultime volontà da rispettare ". In Saggi, poesie, scritti varii.Milano: Arnoldo Mondadori Editore, 1993, p. 1289.
} 
c) o animal, o campo e a cidade.

A trajetória temática, inclusive aquela dos animais na novelística de Pirandello, assim como a dos escritores meridionais da época, como indicou Gino Tellini ${ }^{200}$, se desenvolve num sentido que vai de sua Sicília natal para as grandes cidades, para então retornar, já decantada e amadurecida por outras experiências culturais, ao ponto de partida.

Examinando diacronicamente as novelas, é possível verificar que os elementos ligados ao campo e às minas de enxofre, lentamente vão se transformando em elementos urbanos, primeiramente sicilianos, depois romanos e finalmente cosmopolitas, ou seja, ligados às grandes cidades, retornando, de tempos em tempos, e sob nova ótica, à Sicília rural. Obviamente, não é um movimento linear, mas uma espécie de espiral em que alguns pontos se tocam e que, se acompanhada, pode revelar-se um instrumento para compreender a tendência e a evolução da obra do autor.

O animal mais recorrente nas novelas de Pirandello é o cão. Em muitas delas este animal aparece como protagonista, como na novela "Bolinha e Mimi” (1905), já comentada, mas também em "A fidelidade do cão" (1904), "O carrinho de mão" (1917) e "A vingança do cão" (1933). Espaçadas por mais de dez anos, cada uma das três novelas trata dos interesses do autor em cada uma das fases de desenvolvimento de sua obra. $\mathrm{Na}$ primeira, ele estuda o mundo burguês, numa fase de contato com o mundo; na segunda, Pirandello analisa a relação vida e forma, em busca de uma explicação; na terceira, se detém sobre a realidade procurando uma saída e tentando equacionar a cidade e o campo.

Em "A fidelidade do cão", Gianetta, esposa de Lulù Sacchi, é amante do marquês Giulio DelCarpine, ao qual revela que a esposa dele, Livia, é amante de Lulù. Para ter certeza da traição, Giulio Del Carpine vai até o endereço indicado por Livia, onde Lulù teria alugado

\footnotetext{
${ }^{200}$ Cfr. Cap 2. Nota 63.
} 
um quarto para suas relações extraconjugais. Diante do prédio, procura um lugar discreto para observar e se surpreende ao ver que Lulù também está ali com o mesmo propósito, is to é, Lulù também desconfia que a amante o está traindo e vigia a entrada do prédio para se certificar da traição da amante: "Por um equívoco da velha empregada, que chegava depois dos encontros para arrumar o quartinho, Lulú descobrira a infâmia de dona Livia"201.

Até esse ponto, a novela mais parece uma comédia de erros galante da burguesia romana, em que o marido infiel e o amante infiel, querem certificar-se da infidelidade da esposa e da amante. O constrangimento dos dois homens é grande, principalmente quando dom Giulio se dá conta de que junto com Lulù está Lirì, o cãozinho de Livia, “evidentemente perdido pela dona na pressa de subir para o encontro." 202 Lirì está fazendo festa a Lulù, mas, ao ouvir a voz do "outro" dono, o bichinho

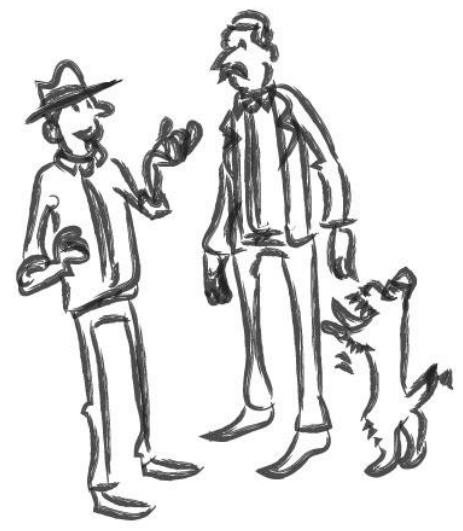

foi tomado por uma súbita alegria; lançou-se sobre as pernas dele, sacudindo-se todo [...] Era realmente um espetáculo muito comovente a fidelidade desse cão de uma mulher infiel, para com aqueles dois homens enganados. Ambos, agora, para se livrar do penoso embaraço em que

\footnotetext{
201 "Per un equivoco preso dalla vecchia serva che si recava dopo i convegni a rassettare il quartierino, Lulú aveva scoperto quell'infamia di donna Livia" PIRA NDELLO, Luigi. "La fedeltà del cane". Referência: ver Anexo B.

202 “smarrito evidentemente dalla padrona nella fretta di salir su al convegno.” Idem.
} 
estavam, assim frente a frente, deleitavam-se muito com a festa frenética que ele thes fazia ${ }^{203}$.

A alegria e a fidelidade do cãozinho fazem contraponto ao embaraço dos dois homens e sua dolorosa descoberta. Assim que Livia sai do apartamento, Lirì a segue, mas os dois homens ficam à espreita para saber quem é o novo amante. Descobrem se tratar de Toti, "um garotão de uns vinte anos, empertigado, rosto afogueado, com um par de bigodes para cima, inverossímeis ${ }^{204}$, . Desapontado, enfurecido, Giulio, antes confiante de sua virilidade e de sua capacidade de agradar às mulheres, compreende que sua esposa não tem apenas um, mas dois amantes. Ainda abalado, vê que Lirì está a seu lado:

Mas, de repente, viu a seu lado, bem quietinho, com as orelhas abaixadas, o rabo entre as pernas, o pobre Liri, que tentara seguir primeiro a dona, depois Toti, depois Lulú e que agora, por fim, começara a segui-lo.

Dom Giulio foi assaltado por uma raiva furiosa: pareceu-lhe obscenamente escandalosa a fidelidade daque le animalzinho e the mandou, também, um violentíssimo pontapé.

- Vá embora! ${ }^{205}$

Esta novela ainda traz muitos elementos do verismo, como a conduta dos personagens com papéis bem determinados na sociedade, suas reações imutáveis e previsíveis, mas já aparece aqui a interferência do acaso - o cãozinho perdido -, que seria impensável em Verga, e também o aspecto psicológico da epifania, da descoberta imprevista e dolorosa, que já prenuncia e delineia a poética do Humorismo. O cão age como elemento perturbador da sequência inexorável dos fatos, mas ainda um tanto timidamente em relação aos resultados

\footnotetext{
203 “fu presa da un subita gioia; gli si slanciò su le gambe, dimenandosi tutta [...] Era davvero uno spettacolo commoventissimo la fedeltà di questo cane d'una donna infedele, verso quei due uomini ingannati. L'uno e l'altro, ora, per sottrarsi al penosissimo imbarazzo in cui si trovavano così di fronte, si compiacevano molto della festa frenetica ch'esso faceva loro." Idem.

204 "un giovanottone suivent'anni, tronfio, infocato in volto, con un pajo di baffoni in su, inverosimili." Idem.

205 "Ma, a un tratto, se lo vide accanto, chiotto chiotto, con le orecchie basse, la coda tra le gambe, quel povero Liri, che s'era provato a seguir prima la padrona, poi il Toti, poi Lulú e che ora infine aveva preso a seguir lui. / Don Giulio fu assalito da una rabbia furibonda: gli parve oscenamente scandalosa la fedeltà di quella brutta bestiola e le allungò anche lui un violentissimo calcio. / - Va' via!” Idem.
} 
que Pirandello irá alcançar mais tarde. Os personagens ainda não apresentam o caráter reflexivo que os destacará definitivamente dos personagens de Verga. O aspecto urbano - a ação se passa numa travessa da Via Veneto, em Roma - e burguês já indica o início da "viagem da consciência" indicada por Tellini.

Em 1917, portanto 13 anos depois de "A fidelidade do cão", Pirandello publica a novela "Carrinho de mão", uma das poucas novelas apresentadas diretamente em livro, na coletânea de novelas E amanhã, segunda-feira (Milano: Treves, 1917).

Já completamente afastado do Verismo e imerso no Humorismo, Pirandello busca as causas do sofrimento humano identificando, entre elas, a máscara que cada um de nós se impõe, ou que é imposta pela sociedade, e que faz com que representemos sempre o mesmo papel, tornando-nos uma marionete de nós mesmos ou dos outros. A máscara, de tempos em tempos, pode ser reformulada, substituída, mas nunca abandonada. Somente um momento único, fugaz e passageiro de epifania, aquilo que Pirandello chama de "entender o jogo", faza máscara cair. Mas o personagem que

viu desmoronarem todas as fantasias com que havia orquestrado sua existência [...] ainda não se pode dizer 'desmascarado', porque a máscara fica, mas postiça, sem sentido, mesmo se irrenunciável, como é incancelável a máscara dos traços físicos que o personagem começa a sentir completamente estranhos à sua verdadeira identidade. ${ }^{206}$

Esse momento de epifania, de "compreensão da realidade", quase sempre leva o personagem à loucura, passageira ou não, ou à morte. A face da realidade não pode ser encarada de frente. Não é possível, vivendo, ver-se viver, pois a máscara não pode existir nua e o personagem que o compreende deve pagar seu preço. É exatamente o que acontece com o

\footnotetext{
206 "ha visto crollare le finzioni con cui aveva orchestrato la propria esistenza [...] non si può dire ancora 'smascherato', perché la maschera resta, ma posticcia ormai, senza senso, anche se irrinunciabile, come incancellabile è la maschera dei tratti fisici che il personaggio comincia a sentire del tutto estranei alla propria vera identità.” MANOTTA, Marco. Luigi Pirandello. Milano: Edizioni Bruno Mondadori, 1998, p. 142.
} 
personagem anônimo de "O carrinho de mão", um proeminente advogado, professor e comendador, casado e com filhos, que um dia, ao voltar para casa de uma viagem de negócios, não se reconhece diante das muitas máscaras que deve usar, impostas pela sociedade ou por ele mesmo.

O momento de epifania se dá quando ele chega diante da porta de casa e vê a placa oval de latão que espelha toda sua vida, mas não espelha ele mesmo.

Vi de repente, diante daquela porta escura, cor de bronze, com a placa oval de latão, onde está gravado meu nome, precedido dos meus títulos e seguido dos meus atributos científicos e profissionais, vi de repente, como de fora, eu mesmo e minha vida, mas para não me reconhecer e para não a reconhecer como minha. [...] Estavam ali, atrás daquela porta que trazia na placa oval de latão o meu nome, estavam ali uma mulher e quatro meninos, que viam todos os dias com um aborrecimento que também era meu, mas que eu não podia tolerar neles, aquele homem ins uportável que eu devia ser, e no qual eu agora via alguém estranho a mim, um inimigo. ${ }^{207}$

O momento de compreensão diante daquela placa/espelho é o reconhecimento da perda de identidade, a identidade que tem muitas máscaras que não se ajustam mais ao que ele sente: "Quem vive, quando vive, não se vê: vive... Se alguém consegue ver a própria vida, é sinal de que não a vive mais: a suporta, a arrasta. Arrasta-a como uma coisa morta,. Porque qualquer forma é uma morte.,208

A discussão sobre a dicotomia "vida e forma", segundo o conceito de Tilgher, fica bem clara nessa novela que é uma das mais emblemáticas sobre o tema. O próprio personagem, anônimo porque sem identidade, proclama que "qualquer forma é uma morte". A

\footnotetext{
207 "Io vidi a un tratto, innanzi a quella porta scura, color di bronzo, con la targa ovale, d'ottone, su cui è inciso il mio nome, preceduto dai miei titoli e seguito da' miei attributi scientifici e professionali, vidi a un tratto, come da fuori, me stesso e la mia vita, ma per non riconoscermi e per non riconoscerla come mia. [...] Ed erano lì, dietro quella porta che recava su la targa ovale d'ottone il mio no me, erano lì una donna e quattro ragazzi, che vedevano tutti i giorni con un fastidio ch'era il mio stesso, ma che in loro non potevo tollerare, quell'uo mo insoffribile che dovevo esser io, e nel quale io ora vedevo un estraneo a me, un nemico." PIRANDELLO, Luigi. "La carriola". Referência: ver Anexo B.

208 “Chi vive, quando vive, non si vede: vive... Se uno può vedere la propria vita, è segno che non la vive piú: la subisce, la trascina. Come una cosa morta, la trascina. Perché ogni forma è una morte.” Idem.
} 
forma na qual ele não se reconhece, no entanto, serve para os outros: "aos senhores estudantes universitários da faculdade de direito, aos senhores clientes que me confiaram a vida, a ho nra, a liberdade, os bens."209

O homem que compreende é um solitário, preso numa forma, ou formas, que não reconhece como sua, mas que compõe para os outros a sua personalidade. Não há meio termo, a solução para a libertação da forma, nesse momento da poétic a pirandelliana, é a insanidade ou a morte. Mas um homem responsável, advogado, professor e pai de família não pode simplesmente deixar tudo de lado, como faz, por exemplo, Vitangelo Moscarda, no romance de 1926, Um, nenhum e cem mil.

O que resta a um homem que precisa manter a máscara da dignidade diante dos outros e de sua família é um pequeno momento de rebeldia, de vingança, que cumpre secretamente todos os dias. Para isso, tranca-se em seu escritório, onde a "velha cadela policial, há onze anos na casa, branca e preta, gorda, baixa e peluda, com os olhos já embaçados pela velhice $^{, 210}$ costuma dormir o dia inteiro e

corro para ela, para a cachorrinha que dorme no tapete; devagar, com elegância, pego suas duas patinhas traseiras e faço um carrinho de mão: isto é, faço com que ela dê oito ou dez passos, não mais, só com as patinhas da frente, segurando-as pelas detrás. [...] meus olhos brilham de prazer, minhas mãos dançam pela volúpia que estou para me conceder, de ser louco, de ser louco só por um momento, de sair por um instante só da prisão desta forma morta, de destruir, de anular por apenas um instante, zombeteiramente, essa sabedoria, essa dignidade que me sufoca e me oprime. ${ }^{211}$

\footnotetext{
209 “ai signori studenti universitari della facoltà di legge, ai signori clienti che m'hanno affidato la vita, l'onore, la libertà, gli averi." Idem.

210 “vecchia cagna lupetta, da undici anni per casa, bianca e nera, grassa, bassa e pelosa, con gli occhi già appannatidalla vecchiaja." Idem.

211 "corro a lei, alla cagnetta che dorme sul tappeto; piano, con garbo, le prendo le due zampine di dietro e le faccio fare la carriola: le faccio muovere cioè otto o dieci passi, non piú, con le sole zampette davanti, reggendola per quelle di dietro. [...] gli occhi mi sfavillano di gioja, le mani mi ballano dalla voluttà che sto per concedermi, d'esser pazzo, d'esser pazzo per un attimo solo, d'uscire per un attimo solo dalla prig ione di questa forma morta, di distruggere, d'annientare per un attimo solo, beffardamente, questa sapienza, questa dignità che mi soffoca e mi schiaccia." Idem.
} 


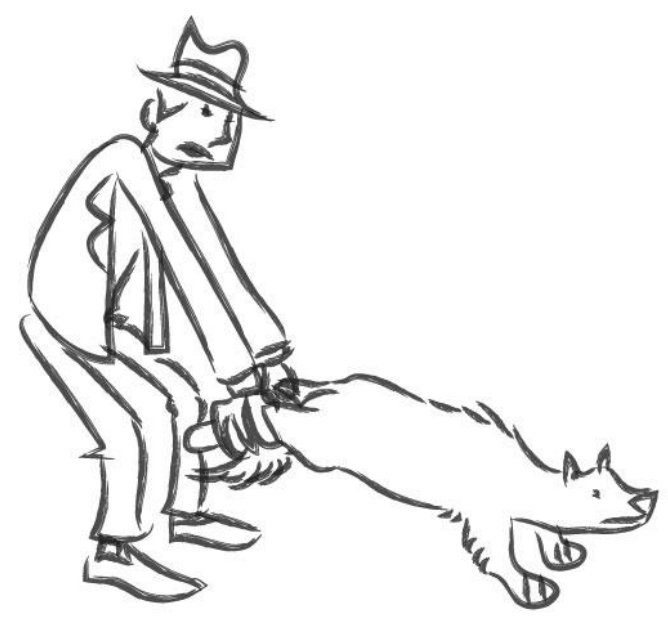

A cachorrinha é o único ser vivo a seu alcance em que ele pode descarregar sua "insanidade temporária" para poder manter a "sanidade" diante dos outros, para desvestir a máscara sem ser criticado, uma vez que o animal não tem máscara e pode compreender esse ato grotesco, e ao mesmo tempo lúdico, a que é sujeitado sem julgar.

Essa novela já apresenta um desenvolvimento da poética pirandelliana em direção à universalidade, o narrador anônimo é o arquétipo do homem cosmopolita sempre representando um papel, seja na profissão, na família ou na sociedade, máscaras que usa tão intensamente a ponto de perder a identidade. Sua identidade real, ou o que ele imagina ser sua identidade real (pois para Pirandello não há uma verdadeira identidade e sim uma incessante troca de máscaras) só pode acontecer num efêmero momento de escapismo, diante do animal capaz de compreender a ação a que é submetido, mas incapaz de julgar porque não está condicionado às leis sociais humanas.

O animal, aqui, é o reverso do espelho representado pela placa de latão em que o protagonista não se reconhece. Durante os poucos instantes em que ele se permite retirar completamente a máscara, o animal é cúmplice silencioso e agente involuntário dessa libertação. 
Se em "O carrinho de mão" o cão é instrumento de libertação, em "A vingança do cão" (1933) o animal é instrumento de vingança. A vingança, ou "vendetta”, é um tema muito ligado à tradição siciliana que Pirandello revisita em algumas de suas novelas. Nessa novela de 1933, há um entrecruzamento de rancores e vinganças movidas por um motivo aparentemente banal, cujo ponto de encontro é o cão. O retorno do autor aos temas sicilianos, já na maturidade de sua vida artística, parece confirmar a trajetória da "viagem da consciência”, identificada por Tellini.

Jaco Naca descobre-se proprietário das terras onde trabalhava como ajudante, quando um forasteiro lhe oferece uma pequena quantia para comprar uma parte delas. Pensando fazer um bom negócio - "Eram rochas, nada mais; com, aqui e ali, alguns tufos de mato, mas que nem as ovelhas, passando, arrancariam para comer" ${ }^{212}$-, logo Naca vê surgir nas terras vendidas dois pequenos e graciosos edifícios de apartamentos de aluguel que dariam uma boa renda ao forasteiro. Naca sente-se enganado e tenta recuperar as terras na justiça, sem resultado, gastando o pouco dinheiro que lhe restara da venda.

Desiludido, enfurecido e mais pobre do que antes, Naca volta "a cultivar o que restou de sua propriedade, o fundo do valão sob aquelas rochas, onde as chuvas, correndo em grossos regatos sobre o acidentado e íngreme declive da encosta, haviam depositado um pouco de terra" ${ }^{\text {213 }}$, onde não crescem mais do que umas poucas amendoeiras ainda infrutíferas e algumas parcas hortaliças.

O contraste entre os edifícios que surgem no alto, frutos da especulação imobiliária, e as amendoeiras infrutíferas no fundo do vale refletem bem o abismo entre as camadas sociais sicilianas. As mais altas não mais compostas pela antiga nobreza, e sim pelo empreendedor

\footnotetext{
212 "Rocce erano, nient'altro; con, qua e là, qualche ciuffo d'erba, ma a cui neppure le pecore, passando, avrebbero dato una strappata.” PIRANDELLO, Luigi. "La vendetta del cane”. Referência: ver Anexo B.

213 "a coltivare il residuo della sua proprietà, il fondo del valloncello sotto quelle rocce, ove le piogge, scorrendo in grossirigagnoli su lo scabro e ripido declivio della poggiata, avevano depositato un po' di terra." Idem.
} 
aproveitador, enquanto as mais baixas ainda compostas pelo pequeno lavrador de terras inférteis.

Para protestar e se vingar de alguma forma, Naca leva "lá para baixo, na fossa, um grande cão de guarda; prendera-o com uma corrente curta cravada no chão, deixando-o ali, dia e noite, morto de fome, de sede e de frio. - Grita por mim!" ${ }^{214} \mathrm{O}$ cão assume o lugar do protagonista, ele também morto de fome, sede e frio, que grita desesperadamente sua raiva e sua incapacidade de fazer alguma coisa, amarrado pelas leis e pelo mais forte. Na novela, Pirandello usa expressões como "entregara-se com a raiva de um cão" 215 , "naqueles do is anos trabalhando como um cão" ${ }^{216}$, e até mesmo compara Naca a um "cão estúpido que, depois de se ter deixado arrancar da boca uma bela coxa de carneiro, agora raivosamente quebrasse os dentes num osso abandonado por quem havia aproveitado a carne" ${ }^{217}$, para reforçar essa relação entre a condição do homem e o cão.

O cão, que durante o dia, na presença do dono, fica quieto por medo, à noite põe-se a latir "tão forte e com um sofrimento tão intenso, implorando socorro e piedade, que todos os inquilinos dos dois edifícios acordavam e não conseguiam mais pegar no sono." ${ }^{218}$ A situação vai se deteriorando a tal ponto que um dos inquilinos, uma noite, dispara contra o cão, causando a revolta de uma vizinha e sua filha.

A novela se alterna entre a crueldade contra o cão, os rancores e inimizades entre os vizinhos, a piedade, as retaliações e a vingança. $\mathrm{O}$ individualismo humano, no qual cada um busca instintivamente as próprias razões, mesmo irracionalmente, é despertado pelo latir do cão que também busca instintivamente denunciar e aliviar seu sofrimento.

\footnotetext{
214 "laggiú nella fossa un grosso cane da guardia; lo aveva legato a una corta caten a confitta per terra, lasciato lí, giorno e notte, morto di fame, di sete e di freddo. - Grida per me!" Idem.

215 "s'era dato con rabbioso accanimento." Idem.

216 "in quei due anni d'accanito lavoro." Idem.

217 "cane balordo che, dopo essersi lasciato strappar di bocca un bel cosciotto di montone, ora rabbiosamente si rompesse i denti su l'osso abbandonato da chi s'era goduta la polpa." Idem.

218 “cosí forte e con tanta intensità di doglia e tali implorazioni d'ajuto e di pietà, che tutti gl'inquilini delle due ville si svegliavano e non potevano piú riprender sonno." Idem.
} 
a violência dos sentimentos em contraste na alma daquela gente, por um lado irritada pelo sono perdido, por outro induzida pela mísera condição daquele pobre cão a uma piedade logo afastada pela forte irritação para com aquele caipirão que fazia do animal uma arma contra eles, não apenas perturbou a delícia de morar naqueles dois edifícios tão admirados, mas exacerbou de tal forma as relações dos inquilinos entre si que, de provocação em provocação, logo se chegou a uma guerra declarada, especialmente entre aqueles dois que primeiro tinha manifestado sentimentos opostos: a viúva Crinelli e o inspetor escolar cavalier Barsi, que tinha atirado. ${ }^{219}$

Enquanto os vizinhos discutem se devem ou não matar o cão - "Matar o cão de um camponês siciliano significava ser morto sem remissão" ${ }^{220}$-, a menina Rorò desce até o local onde está o animal para lhe levar água e comida tentando acalmá-lo. A estratégia parece ter surtido efeito, pois naquela noite o cão se aquieta, o que a menina não sabe é que o inspetor Barsi, durante a madrugada dera comida envenenada ao cão.
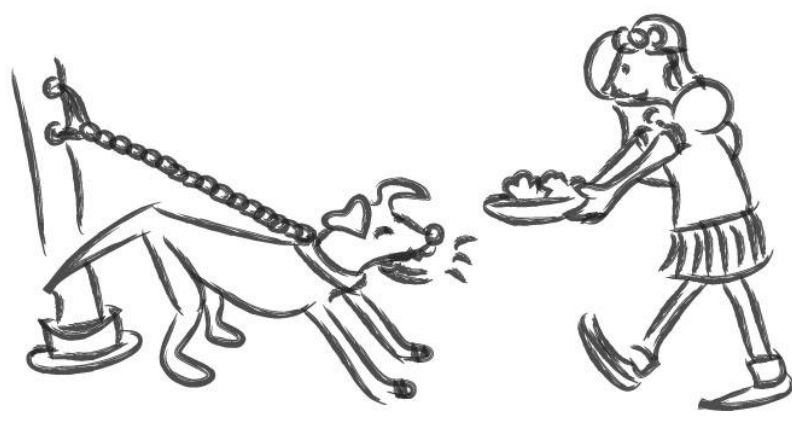

Na manhã seguinte, Rorò desce novamente para dar comida ao cão que parece dormir, mas Jaco Naca está de tocaia e dispara contra ela.

\footnotetext{
219 "la violenza dei sentimenti in contrasto nell'animo di quella gente, da un canto arrabbiata per il sonno perduto, dall'altro indotta per la misera condizione di quel povero cane a una pietà subito respinta dall'irritazione fierissima verso quel villanzone che se ne faceva un'arma contro di loro, non solo turbò la delizia di abitare in quei due villini tanto ammirati, ma inasprí talmente le relazioni degli inquilini tra loro che, di dispetto in dispetto, presto si venne a una guerra dichiarata, specialmente tra quei due che per i primi avevano manifestato gli opposti sentimenti: la vedova Crinelli e l'ispettore scolastico cavalier Barsi, che aveva sparato." Idem.

220 "Ammazzare il cane a un contadino siciliano voleva dire farsi ammazzare senza remissione." Idem.
} 
Lá embaixo, sob a rocha, todo encolhido como uma fera de tocaia, estava Jaco Naca, com o fuzil. A menina, voltando, subitamente deu de cara com ele; teve apenas tempo de olhá-lo com olhos assustados: o tiro ressoou, e a menina caiu de costas, entre os gritos da mãe e dos outros inquilinos, que viram com horror o pequeno corpo rolar encosta abaixo, até o cão inerte, com as quatro patas estiradas. ${ }^{221}$

O triste e atroz final da novela também revela a incomunicabilidade a que estão sujeitos os inquilinos do edifício, microcosmo da sociedade moderna, e a Sicília feudal e desamparada pela nova ordem social.

A revisitação do tema da vingança, por Pirandello, depois de cumprido seu itinerário de conscientização, é filtrada pela amarga conclusão de que muito pouca coisa mudou em sua Sicília natal que, comparativamente, reflete as poucas mudanças ocorridas na Itália da época. Diferentemente de outras novelas envolvendo animais e tendo como tema a vingança, como, por exemplo, "Quem vai pagar" $(1912)^{222}$, que se restringe ao mundo camponês siciliano, “A vingança do cão" mostra o avanço da cidade sobre o campo e os conflitos causados por interesses diferentes.

$\mathrm{Na}$ verdade, as três novelas tratam do mesmo tema: vingança e lealdade. Em "A fidelidade do cão", o marido e o amante da mulher infiel vingam-se no cão, o único personagem fiel; em "O carrinho de mão", o narrador anônimo vinga-se da sociedade, que lhe impõe máscaras, no cão, que fielmente se presta aos desatinos temporários do dono; em "A vingança do cão", Jaco Naca vinga-se de seu destino tratando o animal com a mesma crueldade com que a sociedade o trata, utilizando-o com instrumento e bode expiatório para a insensatez e a falta de lealdade entre os homens.

\footnotetext{
221 “Giú, sotto la roccia, tutto raggruppato come una belva in agguato, era intanto Jaco Naca, col fucile. La bimba, svoltando, se lo trovò di faccia, all'improvviso, vicinissimo; ebbe appena il tempo di guardarlo con gli occhi spaventati: rintronò la fucilata, e la bimba cadde riversa, tra gli urli della madre e degli altri inquilini, che videro con raccapriccio rotolare il corpicciuolo giú per il pendio, fin presso al cane rimasto là, inerte, con le quattro zampe stirate." Idem.

${ }^{222}$ Em “Quem vai pagar", uma porca de estimação é sacrificada por causa de uma discórdia familiar.
} 
d) o animal e o acaso

O acaso, ou melhor, a ação do acaso, é um dos elementos mais importantes na poética pirandelliana, e também uma das razões de sua negação ao Verismo. No Verismo, a conduta "monstruosamente consequencial" ${ }^{223}$ dos personagens não deixa espaço para o acaso, fazendo-os prisioneiros de papéis pré-determinados. Isso se deve, principalmente, à concepção positivista de Verga, que impõe considerar a realidade totalmente subjugada a leis imutáveis, consentindo estabelecer com precisão a genealogia dos fenômenos materiais. "O verismo não dá espaço para nenhum pensamento da diferença e, aliás, em sua monolítica concepção da realidade, absorve qualquer fenômeno na lógica do determinismo" ${ }^{224}$.

Na concepção verista de Verga, o que importa é o "fato", que é irreversível e sempre determina outro "fato", criando uma cadeia de causas e efeitos, na qual cada acontecimento é causado pelo precedente e causa do posterior. Esta cadeia nunca é questionada porque causas e consequências são naturais e independentes da vontade de um indivíduo (personagem), que não deve se rebelar se não quiser cair numa condição social pior do que a precedente. Isto cria uma cadeia circular fechada, que obriga o personagem a viver de um determinado modo e a tomar decisões que sejam aceitas pela sociedade.

Pirandello, ao contrário, tem consciência de que o "fato" não pode ser rigidamente constituído, mas deve ser analisado em suas causas e redimensionado em suas consequências. O "fato" pode ser alterado pela ação do acaso criando uma estrutura aberta que pode levar a

\footnotetext{
223 “mostruosamente consequenziale.” BARILLI, Renato. Pirandello. Milano: Mondadori, 2055, p. 68.

224 "Il veris mo non dà spazio ad alcun pensiero della differenza e, anzi, nella sua monolitica concezione della realtà, riassorbe qualsiasi fenomeno nella logica del determinismo." PETRELLA, Angelo. "Pirandello e la logica della tradizione". In Gli scrittori d'Italia. Il patrimonio e la memoria della tradizione letteraria come risorsa primaria. Atti dell'XI congresso dell'ADI - Napoli, 26-29 settembre 2007, a cura di C.A. Adesso, V. Caputo e O. Petraroli. Ascoli Piceno: Graduus, 2008, p. 87.
} 
resultados inesperados, dependendo da reação do ind ivíduo. Ou seja, o "fato" é o resultado de uma série de combinações casuais dos acontecimentos da realidade e não a realidade em si.

A ação do acaso, em várias novelas, é representada pelo animal. O animal que não está preso a convenções e vive conforme sua natureza é o agente ideal, em Pirandello, para se contrapor ao determinismo social.

Na novela "A mosca" (1904), uma sequência de acasos acaba transformando dois possíveis casamentos em dois prováveis funerais.

Giarlannu Zarù, trabalha na colheita de amêndoas. Ao final de uma jornada de trabalho, em vez de voltar para a cidade, decide esperar seus primos, Neli e Saro Tortorici, que irão passar parte da noite ajudando as mulheres a descascar os frutos. O trabalho se prolonga noite adentro e Giarlannu, cansado de esperar pelos primos, vai dormir num estábulo ali perto. Na manhã seguinte, é encontrado pelos primos "inchado e escuro, com um febrão de cavalo,225. Assustados, os rapazes correm até a cidade para buscar o médico local.

Pirandello, nesse ponto, faz uma digressão sobre a condição do médico: provável arquétipo dos médicos das pequenas comunidades sicilianas. O doutor Sidoro Lopiccolo é um homem atormentado. Com a esposa doente há onze meses, sete filhos para criar sozinho, a casa suja como um chiqueiro, carregando nos braços uma das filhas, "pobre doentinha amarelada, pele e ossos" ${ }^{226}$, Lopiccolo é o retrato do médico de interior desencantado com a profissão pelas agruras da vida. "Retrato" este que Pirandello compara com "um retrato fotográfico ampliado, pendurado na parede; o retrato dele, do senhor doutor Sidoro Lopiccolo, quando ainda era jovenzinho, diplomado de fresco: limpo, alinhado e sorridente" ${ }^{227}$, voltando mais uma vez à questão do espelho e da destruição das ilusões.

\footnotetext{
225 "gonfio e nero, con un febbrone da cavallo." PIRANDELLO, Luigi. "La mosca”. Referência: ver Anexo B. 226 "povera malatuccia ingiallita, pelle e ossa." Idem.

227 "un ritratto fotografico ingrandito, appeso alla parete; il ritratto di lui, del signor dottore Sidoro Lopiccolo, quand'era ancora giovincello, laureato di fresco: lindo, attillato e sorridente." Idem.
} 
O médico aceita assistir o doente, mas exige que os irmãos busquem uma mula para levá-lo. Enquanto Saro sai à procura da mula, Neli vai ao barbeiro fazer a barba, pois pretende mais tarde encontrar a noiva, Luzza (Neli e Giarlannu estão noivos e pretendem se casar no mesmo dia). O barbeiro fere levemente Neli com a navalha, quando ele se volta para a porta para falar com Luzza e com Mita Lunia, a pobre noiva de Giarlannu Zarù. Assim, Pirandello começa a contrapor uma história de amor com uma história de morte.

Chegando ao local onde está Giarlannu, o médico, ao vê-lo "lívido, enorme, irreconhecível [...] o nariz desaparecera com o inchaço; os lábios, negros e horrivelmente tumefatos. E um ronco saía daqueles lábios, exasperado, como um rosnado" ${ }^{228}$, logo chega a um diagnóstico: trata-se de carbúnculo.

O médico explicou a doença como podia, para aqueles dois ignorantes. Algum animal devia ter morrido de carbúnculo nos arredores. Na carcaça, jogada no fundo de algum precipício, quem sabe quantos insetos haviam pousado; algum deles, depois, voando, inoculara a doença em Zarú, naquele estábulo. $^{229}$

O moribundo, neste momento, voltando o rosto para a parede vê, assustado, que "a morte, no entanto, ainda estava ali; tão pequena, que mal se podia percebê-la"230: uma mosca "limpava velozmente as duas finas patinhas dianteiras, esfregando-as como se estivesse satisfeita." 231

\footnotetext{
228 "livido, enorme, irriconoscibile [...] il naso, nel gonfiore, sparito; le labbra, nere e orribilmente tu mefatte. E il rantolo usciva da quelle labbra, esasperato, come un ringhio" Idem.

229 "Il medico spiegò, come poteva a quei due ignoranti, il male. Qualche bestia doveva esser morta in quei dintorni, di carbonchio. Su la carogna, buttata in fondo a qualche burrone, chi sa quanti insetti s'erano posati; qualcuno poi, volando, aveva potuto inoculare il male al Zarú, in quella stalla." Idem.

230 "la morte intanto era lì, ancora; così piccola, che si sarebbe appena potuta sco rgere." Idem.

231 "si nettava celermente le due esili zampine anteriori, stropicciandole fra loro, come soddisfatta" Idem.
} 
Segundo Franco Zangrilli, "Pirandello é um dos primeiros escritores da literatura contemporânea a criar uma série de imagens simbolizando a morte, antes de Joyce e de Kafka.",232

A mosca como agente da morte é também o agente do acaso que pode modificar destinos pré-determinados. Giarlannu deveria se casar com Mita Luzza, mas é impedido por um acontecimento natural não previsto. O determinismo social é posto em xeque diante da natureza indiferente aos sentimentos e às vicissitudes humanas.

A novela poderia terminar nesse ponto, mas Pirandello se detém mais uma vez na ideia da intervenção do acaso utilizando um acontecimento banal: o pequeno ferimento que Neli fez no rosto ao se barbear.

Zarù vê a mosca "alçar voo de repente e virou-se para segui- la com os olhos. Sim, fora pousar na face de Neli. Da face, suavemente, ela agora deslizava depressa para o queixo, até o corte da navalha, e se grudava ali, voraz.",233

Zarù, como que enfeitiçado pela mosca, não adverte o primo de que o inseto está para infectá-lo, enquanto ele está absorto com as palavras do médico. Mais do que isso, levado por uma "profunda inveja, tomado por um ciúme surdo e feroz contra o jovem primo tão belo e saudável, para quem a vida continuava cheia de promessas enquanto ele a perdia repentinamente" ${ }^{234}$, Zarù espera que esta mosca seja a mesma que o infectou: "Ah, se fosse a mesma! Então sim, realmente se casariam juntos!"235.

Dois funerais no lugar de dois casamentos. Na conclusão, resta a figura da natureza “vitoriosa” e Pirandello, num “zoom” cinematográfico, concentra sua atenção, mais uma vez,

\footnotetext{
232 "Pirandello vuol essere uno dei primi scrittori della letteratura contemporanea a creare una serie di immag ini simboleggianti la morte, prima di Joyce e di Kafka." ZANGRILLI, Franco. Il bestiario di Pirandello. Fossombrone: Metauro Edizioni, 2001, p.107 (nota).

233 “un tratto spiccare il volo e si voltò a seguirla con gli occhi. Ecco era andata a posarsi sulla guancia di Neli. Dalla guancia, lieve lieve, essa ora scorreva in due tratti, sul mento, fino alla scalfittura del rasojo, e s 'attaccava lì, vorace.”." PIRANDELLO, Luigi. "La mosca". Referência: ver Anexo B.

234 “cupa invidia, una sorda gelosia feroce lo avevano preso di quel giovane cugino così bello e florido, per cui piena di promesse rimaneva la vita che a lui, ecco, veniva irnprovvisamente a mancare." Idem.

235 "Oh fosse la stessa! Allora sì, davvero, avrebbero sposato insieme!" Idem.
} 
nos mínimos detalhes do inseto "satisfeito" e o isola do contexto, como forma de demolir nossas certezas: "Ali estava ela. Ora punha para fora a pequena tromba e sugava, ora limpava velozmente as duas finas patinhas dianteiras, esfregando-as como se estivesse satisfeita."236

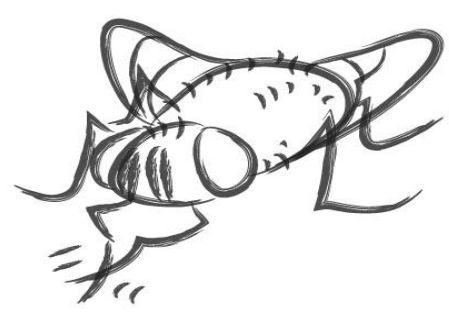

$\mathrm{Na}$ única novela que Pirandello escreveu explorando o tema do "fazer teatral", "O morcego" (1920), o autor se utiliza do animal do título como agente do acaso. Escrita em 1920, já é um prenúncio das reflexões que iriam acontecer no ano seguinte com a montagem de Seis personagens em busca de autor (1921) que, mais tarde, com as peças Cada um à sua maneira (1924) e Esta noite se improvisa (1930) formaria a trilogia "teatro no teatro".

Em "O morcego", o autor teatral Faustino Perres está ensaiando sua nova peça que estreará em breve. A peça é um drama burguês com algumas reviravoltas no enredo, como quase todas as peças da época, inclusive as de Pirandello, que se apoia em alguns truques de luz e na atuação da atriz principal, "a pequena Gàstina", que interpreta o papel de Livia.

Tudo vai bem, exceto pelo fato de que, todas as noites, exatamente durante uma determinada cena interpretada pela Gàstina, surge dentro do teatro um morcego. $\mathrm{O}$ animal esvoaça pelo palco muitas vezes chegando perto da atriz que, assustada e enojada, exige, sem obter resultado, que se encontre uma solução.

\footnotetext{
236 "Eccola. Ora cacciava fuori la piccola proboscide e pompava, ora si nettava celermente le due esili zampine anteriori, stropicciandole fra loro, come soddisfatta." Idem.
} 
Depois de uma fracassada tentativa de localizar o animal, a atriz sugere que o autor faça algumas modificações na peça, talvez reduzindo a intensidade da luz nesse momento, de modo que o bicho, não sendo atraído pela claridade ${ }^{237}$, não entre em cena.

O autor se recusa modificar o texto em nome da realidade de sua criação. Ao colocar na novela a intrusão casual do morcego, Pirandello pretende criticar o teatro tradicional e refletir sobre o tema da ficção teatral e da realidade, ou melhor, sobre a arte e a vida. A relação ator/personagem, que é a mesma relação ficção/realidade, e depois será desenvolvida nos Seis personagens, é discutida quando a atriz, às vésperas da estreia, tenta convencer o autor a mudar a cena, alegando que ela conhece a personagem mais do que qualquer um:

Eu lhe asseguro, eu que devo viver em sua peça o papel de Livia, que isso não é natural; porque Livia, eu sei, sei melhor do que o senhor, o medo que ela tem de morcegos! A sua Livia - veja bem - e não eu. [...]. Mas esta noite, o senhor pode estar certo de que o morcego entrará no palco durante aquela cena. Então eu the pergunto, pela própria realidade que o senhor quer criar, se the parece natural que ela, com o medo que tem de morcegos, com a aversão que a faz se contorcer e gritar só de pensar num possível contato, fique ali como se nada fosse, com um morcego esvoaçando ao redor de seu rosto, e demonstre que não se importa. O senhor está brincando! Livia foge, estou the dizendo; larga a cena e foge, ou se esconde debaixo da mesa, gritando como uma louca. ${ }^{238}$

\footnotetext{
${ }^{237}$ Todo o texto da novela tem pequenas incorreções sobre a natureza do morcego, co mo esta de que ele é atraído pela luz, ou que suas asas são pegajosas. Essas incorreções, ao que parece, não refletem falta de conhecimento de Pirandello sobre o animal, pois ele já demonstrou em outras novelas ser um atento observador da natureza e conhecer bem as características e hábitos dos animais que inclui em suas narrativas, mas são, provavelmente, baseadas no imaginário popular sobre os morcegos. É o que possivelmente indica o seguinte trecho: "Disseram a ela [Gàstina] que o morcego tem nas asas uma viscosidade, que se por acaso encostar na cabeça não é possível desembaraçá-lo dos cabelos, a não ser cortando-os. [Le hanno dato a intendere che, se per caso le sbatte in capo, il pipistrello ha nelle ali non so che viscosità, per cui non è più possibile distrigarlo dai capelli, se non a patto di tagliarli.] PIRANDELLO, Luigi. "il pipistrello". Referência: ver Anexo B.

238 "V'assicuro io, io che debbo vivere nella vostra commedia la parte di Livia, che questo non è naturale; perché Livia, lo so io, lo so io meglio di voi, che paura ha dei pipistrelli! La vostra Livia, - badate - non più io. [...]. Ma questa sera, potete esser certo che il pipistrello entrerà nella camera durante quella scena. E allora io vi domando, per la realtà stessa che voi volete creare, se vi sembri naturale che ella, con la paura che ha dei pipistrelli, col ribrezzo che la fa contorcere e gridare al solo pensiero d'un possibile contatto, se ne stia lì come se nulla fosse, con un pipistrello che le svolazza attorno alla faccia, e mostri di non farne caso. Voi scherzate! Livia se ne scappa, ve lo dico io; pianta la scena e se ne scappa, o si nasconde sotto il tavolino, gridando come una pazza." Idem.
} 
Com efeito, o morcego aparece durante a estreia e a atriz, sentindo as asas do animal tocarem seu rosto, desmaia. A peça que até o momento não tinha sido bem recebida pelo público tem seu momento de glória. Pensando se tratar de um desmaio muito bem interpretado, o público explode em fragorosos aplausos, exigindo a presença do autor e dos atores em cena.

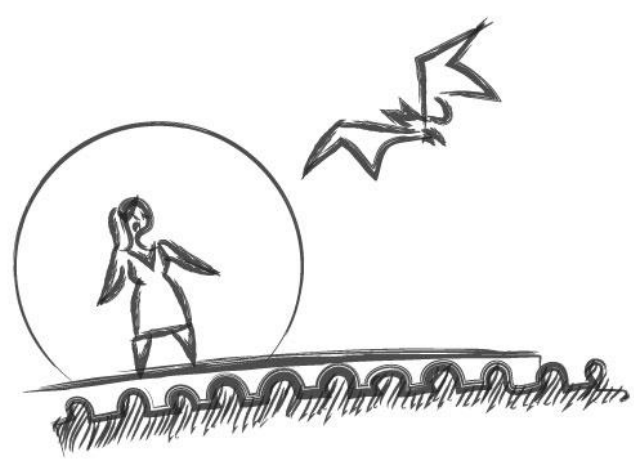

Sim! Aplausos! Aplausos! Era um de lírio de aplausos! Todo o público, em pé, aplaudia freneticamente a quatro minutos, e chamava o autor e os atores ao palco, para decretar o triunfo daque la cena do desmaio, que havia levado a sério como se estivesse na peça, e que tinha visto representar com tão prodigiosa verdade. ${ }^{239}$

A representação é interrompida alegando-se um mal estar da atriz em virtude do realismo da interpretação. Mais tarde, o diretor da peça tenta convencer o autor a incluir a cena do desmaio causado pelo morcego, sem se dar conta de que o morcego verdadeiro poderia ou não aparecer durante a representação, que o acaso é imprevisível, como afirma

\footnotetext{
239 "Ma sì! Applausi! applausi! Era un delirio d'applausi! Tutto il pubblico, levato in piedi, applaudiva da quattro minuti freneticamente, e voleva l'autore, gli attori al proscenio, per decretare un trionfo a quella scena dello svenimento, che aveva preso sul serio come se fosse nella commedia, e che aveva visto rappresentare con così prodigios a verità." Idem.
} 
sensatamente a atriz: "E como? E como? [...]. Os senhores não entenderam mesmo que isso depende do morcego e não de vocês, meus senhores?"240

Faustino Perres decide retirar a peça de cartaz porque entende que a arte é uma realidade sobre a qual pode interferir outra realidade, a realidade imprevisível e momentânea de todos os dias, e mesmo quando se trata da mesma obra, representada pelos mesmos atores e no mesmo lugar, o resultado nunca é igual, pois está sujeita ao acaso que nem todos os preparativos e ensaios podem controlar. A função do acaso, na figura do morcego, que é praticamente um coadjuvante em cena, demonstra a impossibilidade de fundir realidade criativa com realidade do acaso, a que tanto o teatro quanto a vida estão sujeitos.

Na novela "Fuga" (1923), o senhor Bareggi, sufocado pelo cotidiano, pela família e por uma doença incurável, encontra uma válvula de escape na distração do leiteiro quando este deixa sua carroça sozinha, para atender um freguês.

Cansado dos cuidados da esposa e das duas filhas que parecem "uma galinha desorientada com duas franguinhas cacarejando atrás: corre daqui, foge de lá": para pegar as pantufas, a xícara de leite com gema de ovo" ${ }^{241}$, o senhor Bareggi volta para casa pela rua “ainda mal traçada, ainda sem iluminação e sem o incômodo da civilização, só com três casinhas à esquerda, quase de camponeses" ${ }^{\text {242 }}$, numa noite de nevoeiro, cansado da cidade em que mora e do trabalho repetitivo que faz, "esgotado pela nefrite, aos cinquenta e dois anos,

\footnotetext{
240 "E come? e come? [...]. Ma davvero non capite che qua deve dirlo il pipistrello e non voi, signori miei?" Idem.

241 "una gallina spersa e due pollastre pigolanti dietro: corri di qua, scappa di là: per le pantofole, per la tazza di latte col torlo d'uovo." PIRANDELLO, Luigi. "La fuga". Referência: ver Anexo B.

242 "così appena appena tracciata, ancora senza lumi e senza guasto di civiltà, con tre sole casette a manca, quasi da contadini" Ibidem. A descrição da rua e da região onde mora o senhor Bareggi, lembra muito o local da casa que Pirandello habitava, em Roma, em 1922, conforme descreve Alberto Magni em artigo publicado em "La Fiaccola", de julho de 1922: "Para encontrar o refúgio solitário de Luigi Pirandello, levei cerca de uma tarde. De cima abaixo por aquelas benditas ruas adjacentes à via Nomentana, meio fe itas, meio não, que nunca se sabe como se chamam nem de onde vêm." [Per trovarei il rifugio solitario di Luigi Pirandello mi ci è voluto circa un pomeriggio. Giù e su per quelle benedette strade adiacenti alla via Nomentana, mezze fatte, mezze no, che non si sa mai come si chiamino né da che parte vengano.] PIRANDELLO, Luigi. "La mia arte non ha effluvi”. In Saggi e interventi.Milano: Arnoldo Mondadori Editore, 2006, p.1145. O endereço, hoje, é Via Antonio Bosio, 13B, e abriga o Istituto di Studi Pirandelliani e sul Teatro Contemporaneo.
} 
com pontadas fixas nos rins e os pés inchados que, ao se afundar um dedo, levava um minuto para o edema voltar"243.

O senhor Bareggi sonha que qualquer dia "iria embora; escondido; embora para sempre, sem nunca mais voltar para casa" ${ }^{244}$. A ocasião se apresenta quando encontra a carroça do leiteiro parada em uma esquina. Imediatamente ele sobe para a boleia e

com a alegria daquela imprevista loucura que the saltava pelos olhos, ofegante e estremecendo de contentamento e de medo, já sem se importar mais com o que aconteceria a ele, ao leiteiro e às suas mulheres, no alvoroço de todas as imagens que já turbilhonavam na alma perturbada, deu uma forte chicotada no cavalo e vamos! $!^{245}$

A loucura inesperada do senhor Bareggi, causada pela oportunidade que o acaso lhe apresenta, permite temporariamente que ele esqueça suas vicissitudes e se liberte de todos os encargos que a vida lhe impôs. Apesar de semelhante, não é a mesma situação do protagonista de "O carrinho de mão" (1916), que repetidamente alivia suas tensões retirando a máscara diante da cachorrinha, ou do protagonista de "O trem apitou" (1914), que ao ouvir o apito do trem se transporta rotineiramente para universos paradisíacos. O momento de loucura do senhor Bareggi é único e irrepetível, ocasionado por uma conjugação de fatores casuais que certamente marcará sua vida, mas não a modificará. É muito mais um momento de libertação provisória do que de escapismo, já que não depende da vontade do personagem, nem é um estado mental provocado por algum acontecimento aleatório, mas uma situação concreta proporcionada pelo acaso.

\footnotetext{
243 "logorato dalla nefrite, a cinquantadue anni, con lo spasimo fisso alle reni e quei piedi gonfii che, ad affondare una ditata, prima che l'edema rivenisse sù ci metteva un minuto." Idem.

244 "se ne sarebbe andato via; via di nascosto; via per sempre, senza ritornare a cas a mai più." Idem.

245 “col brio di quell'improvvisa pazzia che gli schizzava dagli occhi, ansante e tutt'un tremito di contentezza e di paura, ormai senza che gli importas se più di rendersi conto di ciò che sarebbe avvenuto e di lui e del lattajo e delle sue donne, nello scomp iglio di tutte le immagini che già gli turbinava nell'animo stravolto, dette una gran frustata al cavallo e via!" Idem.
} 
O cavalo, ao sentir a chicotada, sai em desabalada carreira dentro da névoa cada vez mais densa, em direção ao desconhecido. O cavalo e o homem, ambos subjugados pela vida cotidiana, se completam em seu anseio de liberdade.

Ah, não apenas ele, mas também o cavalo devia ter enlouquecido, ou por causa daquela chicotada no princípio, à qual talvez não estivesse acostumado, ou pela alegria de que naquela noite tivesse terminado mais cedo as entregas, ou por não se sentir mais preso pelas rédeas. Relinchava e relinchava. E o senhor Bareggi via com espanto o impulso furioso das ancas naquela corrida que, a cada arrancada, parecia se investir de um novo alento. $^{246}$

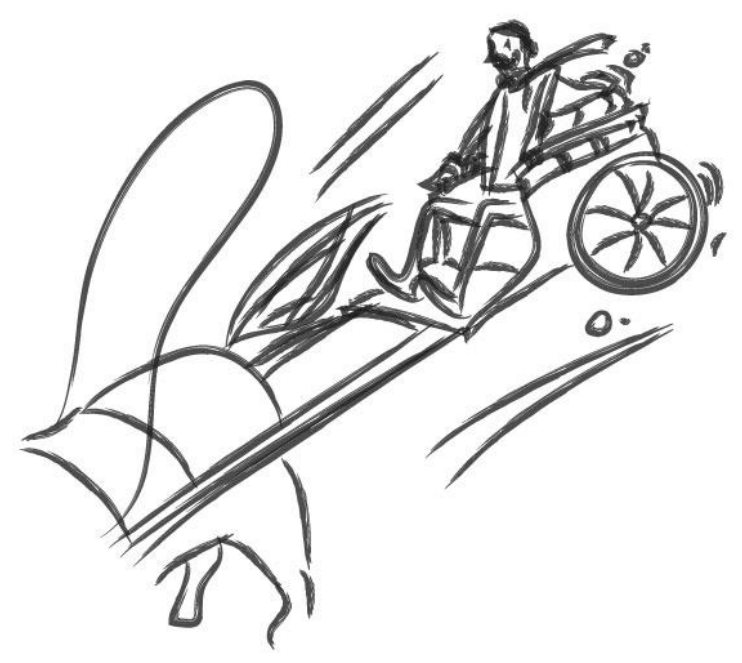

O primeiro sentimento de perplexidade e medo é logo substituído pelo puro prazer da corrida, da sensação de estar sendo arrebatado numa transgressão jamais imaginada:

E o senhor Bareggi ria, apesar do terror que lhe contorcia as entranhas; ria daquele terror; e contrapunha instintivamente à ideia, bastante precisa, de uma próxima e infalível catástrofe a ideia de que, afinal de contas, era uma brincadeira, uma brincadeira que fizera e que no dia seguinte contaria, rindo.

\footnotetext{
246 “Ah, non lui soltanto, ma anche quel cavallo doveva essersi impazzito, o per quella frustata in princip io, a cui forse non era avvezzo, o per la gioja che quella sera fosse finito così presto il giro delle poste, o per le redini da cui non si sentiva più tenuto. Nitriva, nitriva. E il signor Bareggi vedeva con spavento lo slancio furibondo delle anche in quella corsa che, a ogni slancio, pareva si spiccasse ades so con nuova lena." Idem.
} 
[...] Voou pela Ponte Nomentana, voou por Casal dei Pazzi, e corria, corria, corria, pelos campos abertos que já se vislumbrava através do nevoeiro. ${ }^{247}$

Finalmente, o cavalo para "diante de um rústico casebre, com a carreta despedaçada, sem nenhum latão e nenhuma garrafa" 248 . Lá de dentro sai a mulher do leiteiro espantada perguntando pelo marido.

Perguntas às quais o cavalo, ainda ofegante e feliz da bela galopada, certamente não podia responder. Com os olhos ensanguentados, escoiceava e bufava, sacudindo a cabeça. ${ }^{249}$

O senhor Bareggi também não tem respostas. Não há necessidade de respostas, pois resta apenas o prazer da corrida.

"Fuga" é uma das poucas novelas em que o protagonista consegue ter algum prazer com a loucura libertadora, sem se atormentar ou precisar refletir sobre ela. Assim como o cavalo que se regozija com a oportunidade da galopada e depois retorna para casa, o senhor Bareggi também voltará para casa, revigorado pela experiência.

\footnotetext{
247 "E rideva il signor Bareggi, pur nel terrore che gli teneva le viscere sospese; rideva di quel terrore; e contrapponeva istintivamente all'idea, pur precisa, d'una prossima immancabile catastrofe l'idea che, dopo tutto, fosse una burla, una burla che aveva voluto fare e che domani av rebbe raccontato, ridendo. [...] Volò Ponte Nomentano, volò Casal dei Pazzi, e via, via, via, nella campagna aperta, che già s'indovinava nella nebbia." Ibidem.

248 “davanti a un rustico casalino, col carretto sconquassato e senza più né un bidone né un orcio". Ibidem.

249 "Do mande, a cui certo il cavallo, ancora ansante e felice della bella galoppata, non poteva ris pondere. Con gli occhi insanguinati, scalpitava e sbruffava, squass ando la testa." Ibidem.
} 
e) o animal nas últimas novelas

As últimas novelas de Pirandello, aquelas escritas entre 1931 e $1936^{250}$, representam uma espécie de bloco unitário na obra do autor, cronologicamente destacado das novelas anteriores. Alguns críticos, como De Castris ${ }^{251}$, as definiram como "surrealistas", mas trata-se de um surrealismo muito particular que não pode ser comparado ao surrealismo francês, e nem mesmo ao gênero praticado pelos seus contemporâneos Dino Buzzati ${ }^{252}$ e Massimo Bontempelli.

Nessas novelas opera um irreversível estranhamento da vida que coloca o personagem diante de uma nova possibilidade de escapismo, um escapismo mais próximo da redenção, mais ligado à dissolução do personagem e sua reconstrução na natureza. Sobre as últimas novelas, afirma Luperini:

Na última década de sua carreira artística, amadurece em Pirandello uma mudança de poética, com a passagem de uma produção que mira o desvelamento humorista das contradições a uma produção que tende a revelar e celebrar o Ser em sua imobilidade anistórica. ${ }^{253}$

Os animais que aparecem nas últimas novelas, acompanhando essas características, são quase que estranhos ao mundo cotidiano, ou quando não o são, têm um comportamento não usual, muitas vezes apenas imaginado pelo personagem.

\footnotetext{
250 Neste período, Pirandello escreveu apenas 22 novelas: "Um a mais", "As muretas, uma figueira, um passarinho", "Cinci", "Lucilla", "Despejo" "A vingança do cão", "Berecche e a guerra", "Os pés na grama", "À noite um gerânio", "Uma ideia", "Uma jornada", "A prova", "A casa da agonia", "Sorte de ser cavalo", "Um desafio", "O prego", "Vitória das formigas", "Visita”, “A tartaruga", "A lguém está rindo", "Efeitos de um sonho interrompido" e "O bom coração".

${ }^{251}$ DE CASTRIS, Arcangelo Leone. Storia di Pirandello. Bari: Editori Laterza, 1962.

252 Dino Buzzati (1906-1972), em 1945, escreverá A famosa invasão dos ursos na Sicília. Um romance de inspiração surrealista, próximo da fábula.

253 "Nell'ultimo decennio della sua carriera artistica, matura in Pirandello un cambiamento di poetica, con un passaggio da una produzione che punta sullo svelamento umoristico delle contradizioni a una che tende a rivelare e celebrare l'Essere, nella sua immobilità astorica." LUPERINI, Romano. Introduzione a Pirandello. Bari-Roma: Laterza Editori, 1992, p.130.
} 
Na novela "Vitória das formigas" (1936), as formigas são o ponto culminante da loucura do anônimo protagonista que as imagina aliadas com o vento para completar sua derrocada pessoal e financeira. Não se trata, aqui, de uma loucura causada pela epifania de quem "compreendeu a vida", e sim da loucura de quem se dá conta de ter desperdiçado a vida. O protagonista, por ter conduzido uma vida de "verdadeiro porco; mulheres, vinho, jogo" ${ }^{254}$, acaba perdendo a fortuna que o pai lhe deixara, é abandonado pela esposa e pelo filho e vai viver

num palmo de terra que lhe restara de todos os bens que antes possuía, casas e terrenos; um palmo de terra saneada, nos arredores da cidade, na encosta do vale, com um casebre de apenas três cômodos, onde antes morava o camponês que lhe arrendava a terra. ${ }^{255}$

Na solidão, o homem vai remoendo tudo o que deveria ter feito e não fizera, e a única coisa que aplaca sua angústia é o contato com a natureza:

Havia descoberto essa nova riqueza, na experiência de que é preciso muito pouco para viver bem e sem preocupações; com o mundo todo para si, já que não se tem mais casa, nem família, nem cuidados, nem negócios; sujo, maltrapilho, vá lá, mas em paz; ficar sentado à noite, à luz das estrelas, na soleira de um casebre; e se aparecer um cachorro, também perdido, fazê-lo deitar ao lado e acariciar sua cabeça: um homem e um cão, sozinhos na terra, sob as estrelas. ${ }^{256}$

\footnotetext{
254 “vero porco; donne, vino, giuoco." PIRANDELLO, Luigi. "Vittoria delle formiche”. Referência: ver Anexo B.

255 "in un palmo di terra che gli era restato di tutti i beni che prima possedeva, case e poderi; un palmo di terra bonificata, sotto il paese, sul ciglio della vallata, con una catapecchia di appena tre stanze, dove prima abitava il contadino che aveva in affitto la terra." Idem.

256 “Aveva scoperto questa nuova ricchezza, nell'esperienza che può bastar così poco per vivere; e sani e senza pensieri; con tutto il mondo per sé, da che non si ha più casa né famig lia né cure né affari; sporchi, stracciati, sia pure, ma in pace; seduti, di notte, al lu me delle stelle, sulla soglia d'una catapecchia; e se s'accosta un cane, anch'esso sperduto, farselo accucciare accanto e carezzarlo sulla testa: un uomo e un cane, soli sulla terra, sotto le stelle." Idem.
} 
A reintegração do homem à natureza é, nessas últimas novelas, o principal tema de Pirandello, que busca aí a solução para as angústias humanas. Deixando de lado a forma, as máscaras, o espelho, voltando aos valores primordiais, o homem pode, então, sentir-se redimido e tentar um renascimento dissolvendo-se na, agora, mãe natureza.

Essa sensação de alívio, porém, é interrompida pelo aparecimento das formigas que invadem seu casebre e lhe perturbam a paz:

Eram formigas minúsculas e delgadas, frágeis e rosadas, um sopro podia levar mais de cem; mas logo outras cem surgiam de todas as partes; e como trabalhavam; a ordem na pressa; estas equipes aqui, estas outras lá; num vai e vem sem descanso; chocavam-se, desviavam por um trecho, mas depois voltavam ao caminho, e decerto entendiam-se e se consultavam entre elas. ${ }^{257}$

Formigas que, assim como seus pensamentos, não permitem que ele se integre completamente à natureza. Pensamentos pequeninos que "um sopro podia levar mais de cem; mas logo outras cem surgiam de todas as partes", pensamentos, remorsos e arrependimentos que "num vai e vem sem descanso; chocavam-se, desviavam por um trecho, mas depois voltavam ao caminho".

Aos poucos as formigas/pensamentos vão tomando conta do personagem, inclusive fisicamente, como uma doença que se alastra incontrolavelmente.

Encontrara-as por todas as partes, em todas as gavetas; vira-as sair de onde menos se esperava; algumas vezes encontrara-as até na boca, ao comer algum pedaço de pão que deixara por um momento sobre a mesa ou em outro lugar. [...]

À certa altura viu-as sair pelas mangas da camisa sobre as mãos dependuradas, formigas que passeavam, sob a camisa, em seu corpo como se

\footnotetext{
257 "Erano formiche piccolissime e della più lieve esilità, fievoli e rosee, che un soffio ne poteva portar via più di cento; ma subito cento altre ne sopravvenivano da tutte le parti; e il da fare che si davano; l'ord ine nella fretta; queste squadre qua, quest'altre là; viavai senza requie; s'intoppavano, deviavano per un tratto, ma poi ritrovavano la strada, e certo s'intendevano e consultavano tra loro." Idem.
} 
estivessem em casa. Ah, talvez por isso não conseguisse mais dormir à noite e todas as preocupações e remorsos o assaltassem. ${ }^{258}$

Para dar combate às formigas, o personagem resolve atear fogo ao formigueiro, mas uma rajada de vento faz o fogo atingir o casebre, que ficava a dois passos dali. Em desespero, o homem entra no casebre para apagar o fogo, mas os vizinhos o retiram de lá "horrivelmente queimado e ainda vivo, aliás, furiosamente exaltado, gesticulando, com chamas nas vestes e nos cabelos desgrenhados" 259 , para morrer poucas horas depois no hospital, em delírio, gritando contra o vento e as formigas: - Aliança... aliança... Irremediavelmente louco.

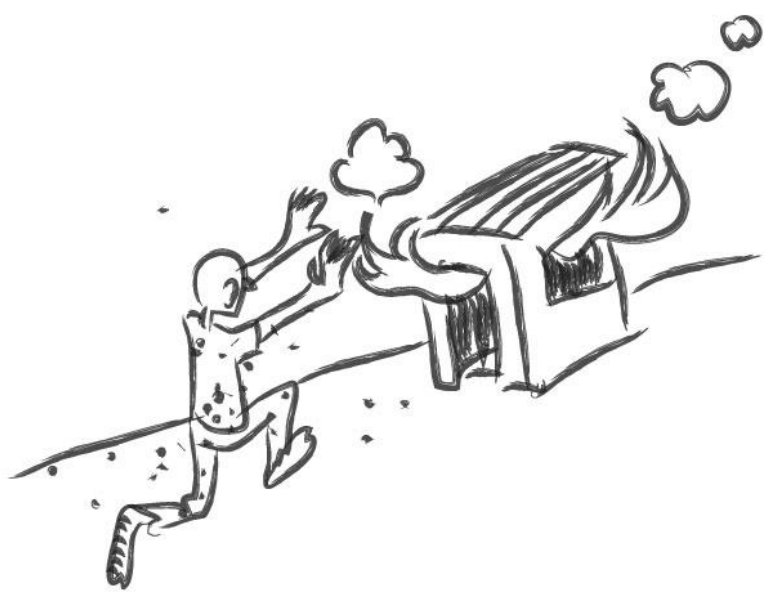

A mensagem de Pirandello nessa novela talvez seja a de que dissolução na natureza também cobra seu preço, e que não é possível trazer para o seu seio a vida passada, muito menos quando ainda há arrependimentos ou remorsos por tudo aquilo que se deveria ter feito e não se fez. $\mathrm{O}$ vento que tudo varre, assim como o tempo, pode ser tão inclemente quanto o

\footnotetext{
258 "Pur le aveva trovate da per tutto, in tutti i cassetti; le aveva vedute venir fuori donde meno se le sarebbe aspettate; se l'era trovate anche in bocca talvolta, mangiando qualche pezzo di pane lasciato per un momento sulla tavola o altrove. [...] $\mathrm{E}$ ad un certo punto ecco che si vide uscire dalle man iche della camicia su quelle mani penzoloni le formiche, le formiche che dunque sotto la camicia gli passeggiavano sul corpo come a casa loro. Ah, perciò forse la notte lui non poteva più dormire e tuttii pensieri e i rimorsi lo riassalivano." Ibidem. 259 "orribilmente arso e non ancor morto, anzi furiosamente esaltato, annaspante con le braccia, le fiamme addosso, sugliabiti e nei ricci svolazzanti sul capo." Ibidem.
} 
fogo que ele espalha. Para o anônimo protagonista não há escapatória, já que o fogo do arrependimento o devora por dentro, engolindo inclusive seus pensamentos.

Interessante notar que "Vitória das formigas" tem vários pontos de contato com o conto "Uma formiga", de Vitaliano Brancati (1907-1954), publicado dois anos antes (1934). ${ }^{260}$ No conto de Brancati, o protagonista, Domenico Rinaldi vive em solidão depois da ruína da família. Uma noite, vigília da festa de Santa Rosalia ${ }^{261}$, num gesto de vingança existencial, queima uma formiga na chama de uma vela. Um gesto inexplicável que o enche de remorsos e ao qual atribui sua maldição. Em Pirandello, no entanto, são as forças da natureza, presentes dentro do próprio protagonista que encerram sua maldição.

Assim como a formiga, industriosa e ordeira nas fábulas, serviu a Pirandello para representar os pensamentos que consomem um homem, outro animal de fábula, a longeva, sábia e paciente tartaruga ${ }^{262}$ é utilizada pelo autor para representar a incomunicabilidade de um casamento numa novela ambientada em Nova Iorque ${ }^{263}$.

Em “A tartaruga" (1936), o senhor Myshkow ${ }^{264}$ ganha de um amigo uma tartaruga, sob a alegação de que o animalzinho traz sorte, uma vez que ele o utiliza diariamente para saber se as ações da bolsa de valores irão subir ou cair, e nunca falhou.

Pensando agradar seus filhos, o senhor Myshkow leva a tartaruga para casa. No trajeto, os primeiros traços da personalidade do protagonista vêm à tona:

\footnotetext{
${ }^{260}$ BRANCATI, Vitaliano. "Una formica". In Racconti, teatro, scritti giornalistici. Milano: Arnoldo Mondadori Editore. Coll. Meridiani, 2003, pp. 542-546.

${ }^{261}$ Santa Rosalia é a padroeira de Palermo, capital da Sicília.

262 A tartaruga também aparece nas novelas "Notícias do mundo" (1901) e "Medo de ser feliz" (1911), como símbolo da teimosa luta contra as adversidades da vida.

263 "A tartaruga", "Um desafio" e "O prego", todas as três de 1936, são as únicas novelas de Pirandello ambientadas nos Estados Unidos. O traço de união entre essas novelas é a incomunicabilidade gerada pela cidade grande.

${ }^{264} \mathrm{O}$ sobrenome Myshkow, levando em conta as características do personagem, segundo Pasquale Marzano, pode estar as sociado ao adjetivo "meschino", dando a entender que este personagem é hu milde, desafortunado, pobre de espírito. MARZANO, Pasquale. Quando il nome é "cosa seria". L'onomastica nelle novelle di Pirandello. Pisa: Edizioni ETS, 2008, p. 535.
} 
Mister Myshkow é muito sensível: levando para casa a tartaruga (ih! ah!) toda sua figurinha elástica, gorducha e sanguínea estremece em arrepios, que talvez sejam de prazer, mas também um pouco de nojo. Não se importa se os outros na rua se voltem para olhá-lo com aquela tartaruga na mão; estremece só de pensar que aquilo que parece uma pedra inerte e fria, não é uma pedra, é habitada dentro por um misterioso animalzinho que de um momento para o outro pode colocar para fora, sobre sua mão, quatro patinhas tortas e ásperas, e uma cabecinha de velha monja enrugada. Esperemos que não o faça. Mister Myshkow talvez a jogasse no chão, arrepiando-se da cabeça aos pés. ${ }^{265}$

A familiaridade do protagonista com a natureza não é muito grande e enquanto o bichinho continuar na sua mão como uma "pedra inerte e fria" e não mostrar sua "cabecinha de velha monja enrugada" ele conseguirá carregá-lo.

Ao chegar em casa, o senhor Myshkow coloca a tartaruga "no tapete da sala, como uma pedra" ${ }^{266}$, mas seus filhos, John e Helen, não demonstram entusiasmo. Ao tentar fazê-los se interessarem pela tartaruga, o senhor Myshkow nota como os olhos deles parecem velhos em comparação com os seus e como nunca foi capaz de conhecê-los realmente.

Olha para a tartaruga [...] olha os olhos dos filhos, e percebe de repente uma misteriosa relação, que o perturba profundamente, entre a velhice daqueles olhos e a secular inércia de pedra daquele bicho sobre o tapete. E fica perplexo com sua incurável jovialidade, num mundo que deixa transparecer, com relações tão distantes e inesperadas, a própria decrepitude: a perplexidade de que ele, sem saber, talvez tenha esperado algo que não virá

\footnotetext{
265 "Mister Myshkow è molto sensibile: portandosi in casa la tartaruga (ih! ah!) freme in tutta l'elastica personcina pienotta e sanguigna per brividi, che son forse di piacere, ma anche di ribrezzo un po'. Non si cura se gli altri per via si voltino a guardarlo con quella tartaruga in mano; lu i fre me al pensiero che quella che pare una pietra inerte e fredda, non è una pietra no, è abitata dentro da una misteriosa bestiola che da un mo mento all'altro può cacciar fuori, sulla mano, quattro zampini sbiechi rasposi e una testina di vecchia monaca rugosa. Speriamo che non lo faccia. Forse Mister Myshkow la getterebbe a terra, raccapricciando da capo a piedi." PIRANDELLO, Luigi. "La tartaruga". Referência: Ver Anexo B.

266 “come un ciottolo sul tappeto del salotto." Idem.
} 
mais, uma vez que na terra as crianças já nascem centenárias como as tartarugas. $^{267}$

À primeira constatação da incomunicabilidade com os filhos, segue-se a incomunicabilidade com a esposa, com quem é casado há nove anos, e com quem sempre viveu na angústia de que ela lhe pedisse divórcio. A esposa é, como a tartaruga, uma mulher inerte e fria, ao passo que o senhor Myshkow é um homem sensível e repleto de vida, sempre aberto para perceber o novo no cotidiano:

A vida para ele nunca é algo de preciso, nem tem qualquer peso das coisas sabidas. Pode the acontecer muito bem que, uma manhã, vendo-se nu com uma perna levantada para entrar na banheira, ficar estranhamente impressionado com o próprio corpo, como se, nos quarenta dois anos que tem, nunca o tivesse visto e descubra isso agora pela primeira vez. ${ }^{268}$

Enquanto sua esposa, mesmo depois de nove anos de casamento é

tão distanciada e isolada de tudo na própria beleza de estatueta de porcelana, tão fechada e esmaltada, de um modo de ser tão impenetravelmente suo, que parece até impossível ter encontrado um jeito de se unir em matrimônio com um homem tão carnal e sanguíneo como ele. ${ }^{269}$

A senhora Myshkow, impenetrável como uma estatueta de porcelana, mesmo depois de nove anos de casamento, é como a tartaruga fechada dentro de seu casco, na em medida que não deixa transparecer que dentro dele há um ser vivo. Dessa forma, num a mbiente sem

\footnotetext{
${ }^{267}$ Guarda la tartaruga [...] guarda gli occhi dei suoi ragazzi, e avverte di colpo una misteriosa relazione che lo turba profondamente tra la vecchiaja di quegli occhi e la secolare inerzia di pietra di quella bestia sul tappeto. È preso di sgomento per la sua inguaribile giovanilità, in un mondo che accusa con relazioni così lontane e inopinate la propria decrepitezza: lo sgomento che lui, senza saperlo, sia forse rimasto ad aspettare qualcosa che non arriverà più, dato che ormai sulla terra i bambini nascono centenaricome le tartarugh e." Idem.

268 "La vita per lui non è mai nulla di preciso, né ha alcun peso di cose sapute. Gli può accadere benissimo qualche mattina, vedendosi nudo con gamba alzata per entrare nella vasca da bagno, di restare stranamente impressionato del suo stesso corpo, come se, in quarantadue anni che lo ha, non l'abbia mai veduto e se lo scopra adesso per la prima volta." Idem.

269 “così distaccata e isolata da tutto, dalla propria bellezza di statuetta di porcellana e così chiusa e smaltata in un modo d'essere così impenetrabilmente suo, che proprio pare impossibile che abbia trovato il modo d'unirsi in matrimonio con un uomo così di carne e sanguigno come lui." Idem.
} 
contato com a natureza (a casa do senhor Myshkow é "toda vidros e espelhos") e com uma mãe superficial e apática, fechada em si mesma, é possível entender porque os filhos já nasceram velhos:

Porém, entende-se muito bem como da união deles tenha sido possível nascer aqueles dois filhos raquíticos. Talvez, se Mister Myshkow tivesse podido carregá-los no ventre, ao invés da esposa, não teriam nascidos assim; mas foi ela quem os carregou no ventre, por nove meses cada um, e então, provavelmente concebidos íntegros no princípio e obrigados a permanecer fechados por tanto tempo num ventre de faiança, como confeitos numa caixa, tenham enve lhecido tremendamente, ainda antes de nascerem. ${ }^{270}$

Mas o senhor Myshkow tem sua parcela de culpa nessa incomunicabilidade, pois ele também se refugiou em seu casco, procurando ignorar a frieza e distanciamento da esposa desde o primeiro momento:

O primeiro dia de casamento fora o mais terrível para ele, porque, como se pode facilmente imaginar, não estava bem seguro de que Mistress Myshkow soubesse o que ele deveria fazer para poder se considerar efetivamente seu marido. Por sorte, ela sabia. Mas depois, não the dera a entender, de alguma forma, que se recordasse da intimidade que eles tiveram. Como se ela não tivesse entregado algo de seu que ele pudesse tomar, e ela recordar. Mesmo assim uma primeira filha, Helen, nascera; e depois um segundo filho, John. Mais nada. ${ }^{271}$

\footnotetext{
270 "Si capisce invece benissimo come dalla lo ro unione siano potuti nascere quei due fig li imbo zzacchiti. Forse, se Mister Myshkow avesse potuto portarli in grembo lui, invece della moglie, non sarebbero nati così; ma dovette portarli in grembo lei, per nove mesi ciascuno, e allora, concepiti probabilmente interi fin dal principio e costretti a rimanere chiusi per tanto tempo in un ventre di majolica, come confetti in una scatola, ecco, s'erano così tremendamente invecchiati prima ancora che nascess ero." Idem.

271 "Il primo giorno di matrimonio era stato per lui il più terribile perché, come si può facilmente immag inare, c'era arrivato non ben sicuro che Mistress Myshkow sapesse che cosa lui dovesse fare per potersi dire effettivamente suo marito. Per fortuna, lo sapeva. Ma poi non gli aveva lasciato intendere in alcun modo che si ricordasse della confidenza che lu i s'era presa. Proprio come se nulla ci avesse mai messo di suo, perché lui se la potesse prendere, e lei ricordare. Eppure una prima figliuola, Helen, era nata; e poi era nato un secondo figliuolo, John. Mai niente.” Idem
} 
Mesmo os filhos, que poderiam ser um motivo para suportar o casamento, são como dois estranhos ao senhor Myshkow, pois a esposa nunca permitiu que ele a acompanhasse à maternidade. As crianças poderiam ser perfeitamente filhos de outros pais, adotados sem que ele soubesse, já que nem mesmo sabia que a esposa estava grávida:

De modo que ele, não tendo notado, nem da primeira, nem da segunda vez que ela estava grávida e depois não sabendo nada, nem das dores do parto, nem do nascimento, encontrara em casa aqueles dois filhos como dois cachorrinhos comprados em viagem, sem nenhuma verdadeira certeza de que tivessem nascido dela e que fossem seus. ${ }^{272}$

Essa incomunicabilidade entre quatro pessoas e a impossibilidade de convivência na cidade grande, distante e alienada da natureza, configura, aliás, um dos temas centrais de Pirandello em sua última fase. Nas últimas novelas, o contraste entre cidade e campo torna-se tanto mais insistente quanto mais cresce em Pirandello o pessimismo. Quanto mais Pirandello adquire consciência do sentido trágico da vida, mais a cidade aparece como a causadora de todos os males, enquanto a natureza, em contrapartida, ganha um fascínio cada vez maior com a promessa de uma paz consoladora. Por isso, nessas novelas, a cidade ganha dimensões cada vez maiores. Em muitas delas não figura mais a Roma dos anos anteriores, mas as vertiginosas cidades americanas.

A senhora Myshkow, ao chegar em casa, intima o marido a se livrar da tartaruga. Ele então compreende que é isso apenas um pretexto para a separação, mas mesmo assim sai para tentar encontrar um lugar onde deixar aquele pobre animalzinho insociável na hostil e fantasmagórica cidade que o envolve:

\footnotetext{
272 "Cosicché lui, non essendosi potuto accorgere né la prima né la seconda volta che lei fosse incinta e non sapendo poi nulla né delle doglie del parto né della nascita, s'era trovati in casa quei due figli come due cagnolini comperati in viaggio, senza nessuna vera certezza che fossero nati da lei e che fossero suoi." Idem.
} 
Sai para a rua, de novo com a tartaruga na mão, para deixá-la em algum lugar que possa que possa ser mais conveniente para o bichinho insociável do que sua casa. Já era noite e ele só se dá conta agora e se surpreende. Mesmo habituado como é à visão fantasmagórica daquela sua enorme cidade, sempre tem novos olhos para se espantar e também sentir um pouco de melancolia, quando pensa que a todas aquelas prodigiosas construções é negado de se imporem como monumentos duráveis e que estão ali como colossais e provisórias manifestações de uma imensa feira, com aqueles imóveis lampejos de luzes coloridas que dão uma tristeza infinita ao se passar por elas, e tantas outras coisas igualmente precárias e inconstantes. ${ }^{273}$

O senhor Myshkow tenta devolver a tartaruga à loja em que foi comprada, mas já está fechada. Pensa em deixar o bichinho num táxi, mas se arrepende. Finalmente tenta abandonála num canteiro de rua, mas um policial o impede dizendo que é proibido colocar animais nos canteiros: a cidade toda se fecha para a natureza. A cidade grande também pode ser comparada com a tartaruga, pois dentro de seus edifícios, automóveis, túneis sabe-se que há vida, mas uma vida que se manifesta em partes, nunca deixando se revelar por inteiro, uma vida que não participa de outras vidas e, quando provocada, fecha-se em si mesma.

Compreendendo que tudo é realmente um pretexto da esposa e que o divórcio aconteceria cedo ou tarde, o senhor Mykshow decide enfrentar a situação voltando para casa com a tartaruga:

Encontra a esposa na sala. Sem dizer nada inclina-se e coloca, à sua frente, a tartaruga no tapete, ali, como uma pedra.

A mulher levanta-se, corre para o quarto, volta com o chapeuzinho na cabeça.

\footnotetext{
273 "Va fuori, di nuovo con la tartaruga in mano, per lasciarla in qualche posto che alla povera bestiola scontrosa possa convenire più che la sua casa. S'è fatto sera e lui se ne avvede soltanto ora e se ne meravig lia. Pur abituato com'è alla vista fantasmagorica di quella sua enorme città, ha sempre occhi nuovi per lasciarsene stupire e anche immalinconire un po', se pensa che a tutte quelle prodigiose costruzioni è negato di imporsi come durevoli monumenti e stan lì come colossali e provvisorie apparenze di un'immensa fiera, con quegl'immobili sprazzi di variop inte lu minarie che danno a lungo andare una tristezza infinita, e tant'altre cose ugualmente precarie e mutevoli." Idem.
} 
- Direi ao juiz que o senhor prefere a companhia da sua tartaruga do que a da sua esposa.

E vai embora.

Como se o bichinho, do tapete, tenha entendido, estende para fora imediatamente as quatro patinhas, o rabo e a cabeça, e balançando, quase dançando, caminha pela sala.

Mister Myshkow não pode deixar de se alegrar, mas timidamente; bate as mãos bem devagar e, olhando-a, sente que deve reconhecer, mas sem muita conic ção:

- A sorte! A sorte! $!^{274}$
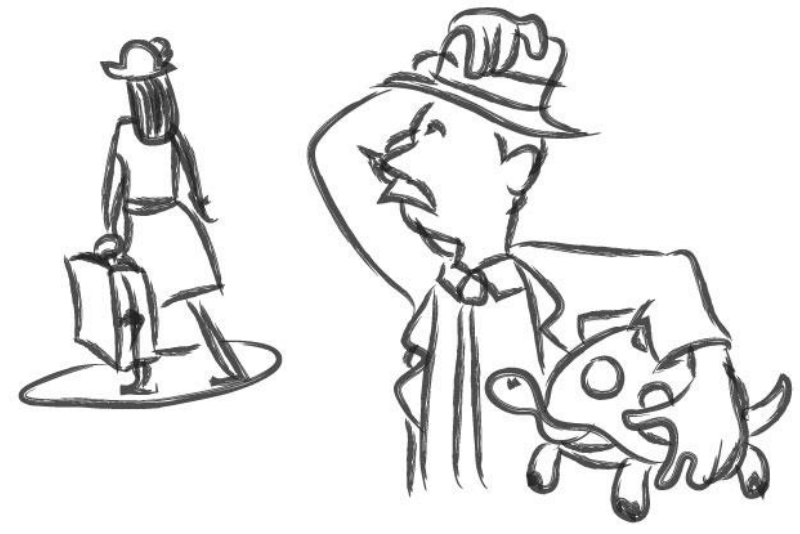

A tomada de posição do senhor Myshkow faz com que ele saia do casco e enfrente finalmente a esposa. Como consequência, a tartaruga também sai do casco e começa a explorar sua nova casa, quase dançando, como timidamente faz o senhor Myrshkow ao aplaudir, reticente, a coragem de ambos.

\footnotetext{
274 “Trova la moglie nel salotto. Senza dirle nulla si china e le posa davanti sul tappeto la tartaruga, là, come un ciottolo. / La moglie balza in piedi, corre in camera, g li si ripresenta col cappellino in capo. / - Dirò al giudice che alla compagnia di vostra moglie preferite quella della vostra tartaruga. / E se ne va. / Come se la bestiola dal tappeto l'abbia intesa, sfodera di scatto i quattro zampini, la coda e la testa e dondolando, quasi ballando, si muove per il salotto. / Mister Myshkow non può fare a meno di rallegrarsene, ma timidamente; batte le mani piano piano, e gli pare, guardandola, di dover riconoscere, ma senza esserne proprio convinto: / - La fortuna! La fortuna!" Idem.
} 
A tartaruga que traz a sorte e as formigas que portam a desgraça são duas faces da mesma moeda, são o preço que o homem tem que pagar por ter se afastado da natureza, mesmo, como no caso das formigas, estando imerso nela.

Uma das novelas mais intrigantes de Pirandello pertence à fase final do autor. Em "A prova" (1935), dois ursos são enviados por Deus para por à prova dois clérigos que estão de partida para atuarem como missionários na China.

O urso, como personagem, não é um animal comum na literatura do início do século XX, sobretudo na narrativa italiana, aparecendo mais tarde no romance-fábula de Dino Buzzati, A famosa invasão dos ursos na Sicília, de 1945, e na "utópica fábula poética" urso europeu ou a loja de brinquedos, de Gianfranco Draghi, de 1952. Além disso, não são comuns na obra de Pirandello a figura de Deus e do Diabo, senão associadas a superstições ou crenças populares. Esses dois fatores fazem com que essa novela seja ímpar na obra do autor.

Narrada em forma de apólogo ${ }^{276}$, “A prova” está bem próxima às peças que integram a trilogia dos mitos ${ }^{277}$ de Pirandello, nas quais a volta do homem à natureza e a crença em valores fundamentais é uma temática constante. Além disso, apólogo e fábula são formas de narrativa muito próximas, o que também poderia configurar o retorno do autor a seus primeiros experimentos com este gênero.

“A prova" inicia-se com uma espécie de longo preâmbulo em que é narrada a entrada de um urso numa igreja e seu diálogo com o sacristão. Nesse preâmbulo, as primeiras frases causam estranhamento ao leitor que não consegue distinguir claramente o que ou quem faz com que o urso entre na igreja: "Pode lhes parecer estranho que eu esteja, agora, a ponto de

\footnotetext{
${ }^{275}$ BENOZZO, Francesco. “Orsi e cervi”, In Animali della letteratura italiana. Ro ma: Carocci Editore, 2009, p. 176.

${ }^{276}$ Segundo Hegel, o apólogo é "u ma parábola que não utiliza apenas, e a título de analogia, um caso particular a fim de tornar perceptível uma significação geral de tal modo que ela fica realmente contida no caso particular que, no entanto, só é narrado a título de exemp lo especial". HEGEL, Georg W ilhelm Friedrich. Estética, II, $2 c$. Lisboa: Guimarães Editores,1993, p.223.

${ }^{277}$ A nova colônia (1928), Lázaro (1929) e Os gigantes da montanha (1936).
} 
fazer um urso entrar na igreja. Peço que me deixem fazê-lo, porque não sou exatamente $\mathrm{eu}^{, 278}$.

Quando o narrador afirma que está para fazer um urso entrar na igreja e depois diz que não é ele propriamente que o faz, a suspeita da existência de uma força maior instala-se na novela. Negando ser sua a ideia de fazer o urso entrar na igreja, por mais "extravaga nte e sem preconceitos" que ele seja, e atribuindo essa ideia a dois jovens clérigos, o narrador exime-se de qualquer responsabilidade sobre a história que vai contar:

Por mais extravagante e sem preconceitos que eu possa ser, sei do respeito com que devemos nos comportar numa igreja e uma ideia como esta jamais me vira à mente. Mas veio a dois jovens clérigos do convento de Tovel, um nativo de Tuenno e o outro de Flavòn, que tinham ido à montanha para se despedir de seus parentes antes de partir como missionários para a China. ${ }^{279}$

Ao mesmo tempo, Pirandello declara, com essa introdução, que o escritor, enquanto criador, tem completo domínio sobre sua criatura e pode ser comparado a um pequeno deus que comanda sua obra.

Sempre se dirigindo ao leitor, o narrador faz considerações sobre o que é a fé e como os dois clérigos vieram a imaginar que o urso tenha entrado na igreja como um milagre para pô-los à prova antes de sua viagem como missionários à China.

O urso, uma vez na igreja, procura o sacristão e diálogo entre os dois é essencialmente humorista, pois desperta no leitor, num primeiro momento, a "percepção do contrário" e posteriormente, quando o urso afirma que Deus "fala melhor com os animais do que com os

\footnotetext{
278 "Vi parrà strano che io ora stia per fare entrare un orso in chiesa. Vi prego di lasciarmi fare perché non sono propriamente io" PIRANDELLO, Luigi. "La prova”. Referência: ver Anexo B.

279 "Per quanto stravagante e spregiudicato mi possa riconoscere, so il rispetto che si deve portare a una chiesa e una simile idea non mi sarebbe mai venuta in mente. Ma è venuta a due giovani chierici del convento di Tovel, uno nativo di Tuenno e l'altro di Flavòn, andati in montagna a salutare i loro parenti prima di partire missionari in Cina." Idem.
} 
homens" ${ }^{280}$, provoca a reflexão que leva ao "sentimento do contrário", demonstrando que os homens têm uma ideia preconcebida de Deus e são incapazes de decifrarem Seus sinais.

- Por favor, Deus?

O sacristão pergunta perplexo:

- Como, Deus?

E o urso, espantado, abre os braços:

- Não está em casa?

O sacristão ainda não acredita no que vê, tanto que exclama quase em tom de pergunta:

- Mas você é um urso!

- Sim, um urso, como você pode ver; não estou me fazendo passar por outra coisa.

- Sem dúvida, mas um urso quer falar com Deus?

Então o urso não pode deixar de olhá-lo com compaixão:

- Você deveria se espantar de eu estar falando com você, isso sim. Deus, segundo suas regras, fala melhor com os animais do que com os homens. Mas agora me diga se você conhece dois jovens clérigos che partem amanhã como missionários para a China. ${ }^{281}$

A naturalidade com que o urso cumpre sua tarefa contrasta com a incredulidade do sacristão, que não deveria se espantar com os desígnios de Deus. Isto também parece não espantar o narrador que, inclusive, justifica as palavras do urso:

que Deus fale melhor com os animais do que com os homens não me parece que seja coisa de se duvidar, levando em conta que os animais (desde que não tenham qualquer contato com os homens) estão sempre seguros daquilo que fazem, melhor do que se soubessem; não porque esteja certo ou esteja errado (pois essas são melancolias que só os homens têm), mas porque

\footnotetext{
280 "parla con le bestie meglio che con gli uomini." Idem.

281 “- Scusi, Dio? / Il sagrestano trasecola: / - Come, Dio? / E l'orso, stupito, apre le braccia: / - Non sta qui di casa? / Quello non sa ancor credere ai suoi occhi, tanto che esclama quasi in tono di domanda: / - Ma tu sei orso! / - Orso, già, come mi vedi; non mi sto mica dando per altro. / - Appunto, orso vuoi parlar con Dio? / Allora l'orso non può fare a meno di guardarlo con compassione: / - Dovresti invece meravigliarti che sto parlando con te. Dio, per tua norma, parla con le bestie meg lio che con gli uomini. Ma ora dimmi se conosci due giovani chierici che partono domani missionari in Cina." Idem.
} 
seguem obedientes a sua natureza, isto é, o meio de que Deus se serve para falar com eles. Os homens, ao contrário, petulantes e presunçosos, por querer entender tudo pensando com suas cabeças, no final não entendem mais nada; nunca estão certos de nada; e são completamente alheios a essas relações diretas e precisas de Deus com os animais; e digo mais, nem ao menos suspeitam que elas existam. ${ }^{282}$

A relação dos homens com Deus é intermediada pela religião, representada pela figura do sacristão, ao passo que a relação dos animais com Deus é direta, porque os animais "seguem obedientes a sua natureza". A obediência dos animais à sua natureza é uma relação que Pirandello constata desde as primeiras novelas ${ }^{283}$, mas que enfatiza, sobretudo, nas novelas finais como advertência aos homens para seguirem sua natureza.

Descobre-se, ao final desse longo preâmbulo que ocupa metade na novela, que a visita do urso à igreja se passa inteiramente na imaginação dos dois clérigos na tentativa de explicar o que realmente lhes aconteceu, mas que é contada pelo narrador "com uma certa malícia que certamente os dois clérigos, ao imaginá-la, não tiveram." 284

Esse preâmbulo requer muita atenção do leitor, pois se trata quase de uma digressão, uma vez que apresenta uma situação ambígua e imaginária sem que o leitor seja informado de suas causas. Para o leitor habituado à novela pirandelliana essa anomalia talvez seja a principal causa de estranhamento. A novela pirandelliana, em geral, estrutura-se numa

\footnotetext{
282 "che Dio parli con le bestie meglio che con gli uomini non mi pare che si possa mettere in dubbio, se si consideri che le bestie (quando però non siano in qualche rapporto con gli uomini) sono sempre sicure di quello che fanno, meglio che se lo sapessero; non perché sia bene, non perché sia male (ché queste son malinconie soltanto degli uomini) ma perché seguono obbedienti la loro natura, cioè il mezzo di cui Dio si serve per parlare con loro. Gli uomini all' incontro petulanti e presuntuosi, per voler troppo intendere pensando con la loro testa, alla fine non intendono più nulla; di nulla sono mai certi; e a questi diretti e precisi rapporti di Dio con le bestie restano del tutto estranei; dico di più, non li sospettano nemmeno." Idem.

${ }^{283}$ Co mo exemplo, basta ver a novela "O gato, um pintassilgo e as estrelas", de 1917, em que o gato, depois de comer o passarinho, "nem se lembrava mais [...]. Havia feito umbelo salto, depois de pegá-lo fugira e agora lá estava ele - tranquilo, tão branco sobre o telhado escuro olhando as estrelas que da negra profundidade da noite interlunar - disso podemos ter certeza - nem viam os pobres telhados daquela cidadezinha entre os montes." [mica se lo ricordava, [...]. Aveva fatto un bel balzo, al botto, era scappato via e ora - eccolo là - se ne stava tranquillo, così tutto bianco sul tetto nero a guardare le stelle che dalla cupa profondità della notte interlunare - si può essere certissimi - non vedevano affatto i poveri tetti di quel paesello tra $\mathrm{i}$ monti.]. PIRANDELLO, Luigi. “O gato, um pintassilgo e as estrelas”. Referência: ver Anexo B.

284 "con una certa malizia che certo i due chierici, nell'immaginarla, non ci misero.” PIRANDELLO, Luig i. "La prova”. Referência: ver Anexo B.
} 
sequência de três momentos: o primeiro apresenta a situação problemática atual (os fatos); o segundo expõe suas causas (os antefatos); o terceiro conduz a narrativa ao desfecho. $\mathrm{O}$ preâmbulo altera radicalmente esta ordem unindo o segundo e o terceiro momentos apresentando-os logo de início, para depois relatar os fatos. Ou seja, o desfecho da narrativa aquilo que os clérigos imaginaram após o acontecimento dos fatos - confunde-se com o antefato, que acontece apenas na imaginação dos clérigos. Tanto é, que a segunda parte da novela inicia-se com a descrição do realmente acontecido:

O fato é que ao entardecer, voltando ao convento, quando deixaram a trilha da montanha para tomar o caminho que conduz ao vale, os dois jovens clérigos viram o caminho impedido por um urso e um ursinho.

Era final de primavera; portanto não era mais a época em que os ursos e os lobos descem famintos dos montes. Os dois jovens clérigos, até agora, tinham caminhado contentes em meio aos campos plantados já altos, que prometiam uma colheita abundante e com a vista alegrada pela frescura de todo aquele verde novo que, dourado pelo sol que se punha, espalhava-se deliciosamente pelo grande vale. ${ }^{285}$

A cena do encontro dos clérigos com os ursos, da forma como está escrita descrita, remete ao famoso encontro de dom Abbondio com os bravos, no romance Os noivos, de Alessandro Manzoni. Para Pirandello, dom Abbondio, assim como Dom Quixote, é um dos personagens da literatura que já nasceu com a marca do humorismo, pois é capaz, por si só, de despertar no leitor o "sentimento do contrário", sentimento que também despertam os dois clérigos diante dos dois ursos que vão pô-los à prova por ordem de Deus.

\footnotetext{
285 "Il fatto è che sul tramonto, tornandosene al convento, quando lasciarono il sentiero della montagna per prendere la via che conduce alla vallata, i due giovani chierici si videro questa via impedita da un orso e un orsacchiotto. / Era primavera avanzata; non più dunque il tempo che orsi e lupi scendono affamati dai monti. I due giovani chierici avevano camminato finora lieti in mezzo ai lavorati già alti che promettevano un abbondante raccolto e con la vista rallegrata dalla freschezza di tutto quel verde nuovo che, indorato dal sole declinante, dilagava con delizia nell'aperta vallata." Idem.
} 


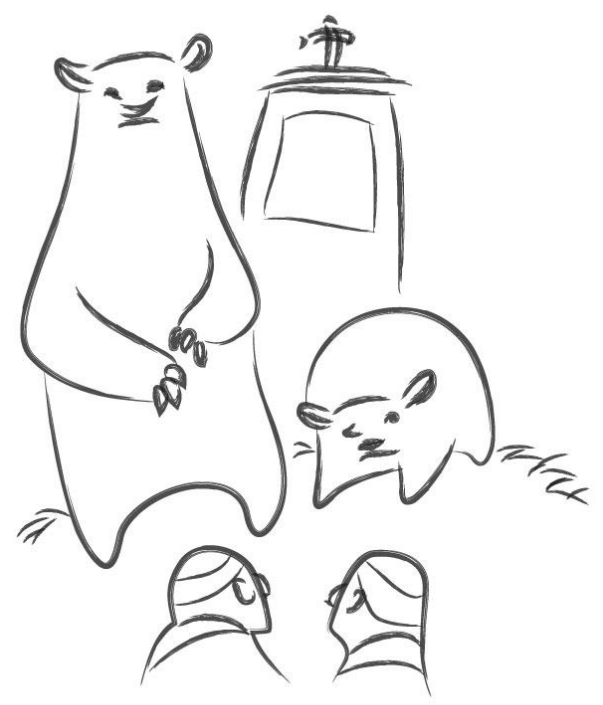

Os clérigos, assim como dom Abbondio, tentam fugir, mas veem que uma menina que está ali perto permanece indiferente aos animais, levando-os a considerar que se trata de uma alucinação ou que os ursos eram domesticados:

Espantados com a indiferença daquela menininha, por um instante acreditaram que, ou aque les dois ursos fossem uma aluc inação, ou que ela já os conhecesse como ursos do lugar, domesticados e inofensivos; pois não podiam admitir que ela não os visse: o maior, ereto e imóvel guardando a estrada, enorme contra a luz e todo negro, e o outro, menor, que vinha se aproximando bem devagar, balançando sobres as patas curtas e que agora começava a girar ao redor do clérigo de Flavòn e, ao girar, cheirava-o devagar por todos os lados. ${ }^{286}$

Os dois clérigos, assustados, trocam um olhar e um sorriso amedrontado.

Considerando aquele sorriso um ato de coragem, os ursos se afastam tranquilamente dando por cumprida sua tarefa. Num primeiro momento, os rapazes poderiam pensar se tratar de coisa do diabo, que mandara os ursos ali para tentá-los, mas logo compreendem se tratar de

\footnotetext{
286 “Stupiti dell' indifferenza di quella ragazzina ebbero per un attimo il dubbio che, o quei due orsi fossero una loro allucinazione, o che lei già li conoscesse come orsi del luogo addomesticati e innocui; perché non era in alcun modo ammissibile che non li vedesse: quello più grosso, ritto là e fermo a guardia della strada, enorme controluce e tutto nero, e l'altro più piccolo che si veniva pian piano accostando dondolante su le corte zampe e che ora ecco si metteva a girare intorno al chierico di Flavòn e a mano a mano girando l'annusava da tutte le parti." Idem.
} 
uma ação de Deus, e ao imaginar o urso entrando na igreja para tentar localizá-los, explodem numa debochada e libertadora risada, que Deus entende como dirigida ao diabo.

Pirandello termina a novela, em tom levemente jocoso, considerando que:

ninguém melhor do que Deus pode saber por experiência continuada que muitas ações, que os homens com sua curta visão imaginam serem más, Ele próprio as faz para seus altos fins secretos, e os homens, ao contrário, acreditam bobamente que seja o diabo. ${ }^{287}$

Com esse apólogo, Pirandello pretende demonstrar a fundamental incompreensão que os homens têm da absurda ideia de Deus, talvez concebida por seus próprios medos, e a falta de familiaridade com a natureza, revelando a pequenez, a miséria, a fragilidade e a miopia dos homens, que "por querer entender tudo pensando com suas cabeças, no final não entendem mais nada". ${ }^{288}$ É um chamado à (re)conciliação com a natureza, chamado que são Francisco, de modo comovente e muitas vezes não atendido, já havia feito há vários séculos. Pois como afirmam Gian Mari Anselmi e Gino Ruozzi:

Nos olhos dos animais, mesmo aqueles mais ferozes (mas nunca tão ferozes quanto o homem), espelham-se uma espécie de inocência primordial, uma raiz antiga do mundo que não devemos nem podemos nos permitir perder. Em seu olhar indefeso existe, inteiro, o pedido de retomarem juntos, homem e todos os seres vivos, homem e criaturas de Deus, [...] um caminho para sair da árida desolação de um mundo sem futuro e desprovido de desejo de vida. $^{289}$

\footnotetext{
287 "nessuno meg lio di Dio può sapere per continua esperienza che tante azioni, che agli uomini per il loro corto vedere pajono cattive, le fa proprio Lui, per i suoi alti fini segreti, e gli uo mini invece credono scioccamente che sia il diavolo." Idem.

288 "per voler troppo intendere pensando con la loro testa, alla fine non intendono più nulla." Idem.

289 "Negli occhi degli animali, anche in quelli più feroci (mai feroci come l'uomo comunque), si rispecchiano una sorta di innocenza primordiale, una radice antica del mondo che non dobbiamo e possiamo permetterci di perdere. Nel loro sguardo indifeso c'è, intera, la rich iesta di riprendere insieme, uo mo e tutti i viventi, uomo e creature di Dio, $[\ldots]$ un cammino per uscire della desolazione arida di un mondo senza futuro e scarso desiderio di vita." ANSELMI, Gian Mario; RUOZZI, Gino. "L'uomo e gli animali". In Animali della letteratura italiana (a cura di Gian Mari Anselmi e Gino Ruozzi ). Roma: Carocci Editore, 2009, p. 12.
} 


\title{
5. Um bestiário (im)possível, a título de conclusão
}

\author{
Sem nada fazer, um leão é leão: \\ e um pobre homem deve enfrentar a morte \\ para ter a honra da comparação \\ com esse animal, sem esforço, forte. ${ }^{290}$
}

290 “Senza far nulla, un leone è leone:/e un pover'uom dev'affrontar la morte / per avere l'onor del paragone / con quella bestia, senza stento, forte." PIRANDELLO, Luigi. "Sempre bestia” (Fuori di chiave). In Saggi, poesie e scritti varii. Milano: Mondadori, 1973, p. 663. 
Assim como o corvo de Mìzzaro sobrevoa com sua sineta a paisagem rural da Sicíla unindo as novelas filmadas pelos irmãos Taviani em $\operatorname{Kaos}^{291}$, os animais, na feliz expressão de Elisabetta Bacchereti, nos espreitam por entre as páginas das novelas de Pirandello. Talvez, por isso, seja possível organizar um bestiário com as suas novelas, como acenou a própria Bacchereti em seu ensaio “A 'animalesca filosofia'. Apontamentos para um 'bestário’ pirandelliano" ${ }^{292}$, ou tentou com algum sucesso Franco Zangrilli em $O$ bestiário de Pirandello $^{293}$.

Gênero que teve muito sucesso na Idade Média, o bestiário busca suas raízes nas fábulas de Esopo, para depois se transformar em tema mítico-religioso, em que o simbolismo e a representação alegórica dos vícios e virtudes pretendiam demonstrar que a sabedoria e a moralidade são veículos para a ascese humana. Mas hoje, quando já se discute o póshumano $^{294}$, que lugar teria um bestiário?

O bestiário enquanto gênero literário,

\footnotetext{
${ }^{291}$ TA VIANI, Paolo e Vittorio. Kaos. 1984. As novelas filmadas são: "O outro filho" (1905), "Mal de lua" (1913), "O Jarro" (1909), "Requiem [aeternam dona eis, Domine]" (1913). A abertura, que serve como prólogo, é inspirada na novela "O corvo de Mìzzaro" (1902) e o epílogo (Colóquio com a mãe) é inspirado na novela "Uma jornada" (1935).

292 BA CCHERETI, Elisabetta. 'L' 'animalesca filosofia'. Appunti per un 'bestiario' pirandelliano. In I segni e la storia. Studi e testemonianze in onore di Giorgio Luti. Firenze: Casa Edittrice Lettere, 1996, pp. 161-191.

293 ZANGRILLI, Franco. Il bestiario di Pirandello. Fos sombrone:Metauro Edizioni, 2001.

${ }^{294}$ Para maiores detalhes da discussão sobre o pós-humano, ver: VIOLA, Francesco. "Umano e post-umano: La questione dell'identità". In Natura, Cultura, libertà (a cura di Francesco Russo). Roma: Armando Editore, 2010, pp. 89-98.
} 
encontra um lugar como categoria temática a partir do momento em que, como o tema, possui uma fisionomia de traços semânticos (centrados na relação humano/animal, instinto/razão, inferioridade/ superioridade) e de topos alegóricos (a ferocidade, a mansidão, a coragem, a fidelidade, o sacrifício...) que caracterizam uma tradição mitopoética e narrativa bem reconhecível. ${ }^{295}$

Tomando-se a ideia de categoria temática, o que se constata é que a presença dos animais na literatura, após o esgotamento dos bestiários medievais no final do século 13, será retomada, em outras bases, a partir dos meados do século 19, porém em obras ainda fortemente alegóricas como Moby Dick (1857), de Melville, O livro da selva (1894), de Rudyard Kipling, ou mesmo o conto Katchtanka, de Tchekhov.

A simples presença de animais, protagonistas ou não, não caracteriza essas obras como bestiários, mesmo porque são obras que incluem, em sua maioria, apenas um animal. Ainda assim, é possível considerar essas narrativas como pertencentes a um grupo temático que inclui animais literários. Ou seja, o tema se torna mais amplo, contemplar outras formas de representação do animal. Isso porque, no final do século XIX e início do século XX, não há mais lugar para bestiários do tipo medieval. Como afirma Julieta Yelin:

As transformações histórico-sociais que afetaram de maneira concreta a relação entre homens e animais - como a migração em massa das populações rurais às grandes cidades, o desaparecimento do animal doméstico útil e o surgimento do animal de estimação, o desenvolvimento da indústria de alimentação e a redução do animal a mera matéria-prima, e a criação e reorganização de jardins zoológicos. [...] a literatura de animais já não contribuiria para a reprodução de determinado valor simbólico de suas figurações, mas, ao contrário, seria o artífice de sua dissolução, ou seja, realizaria um trabalho de desconstrução das metáforas instituídas, cujo motor

\footnotetext{
295 "si ritaglia un luogo come categoria tematica dal mo mento che, co me il tema, possiede una fisionomia di tratti semantici (incentrati sul rapporto u mano/animale, instintività/razionalità, inferiorità/ superiorietà) e di topoi allegorici (la ferocia, la mansuetudine, il coraggio, la fedeltà, il sacrificio ...) che caratterizzano una tradizione mitopoetica e narrativa ben riconoscibile. BIA GINI, Enza. "La critica temática, il tematis mo e il "bestiario". In Bestiari del novecento (a cura di Enza Biagini e Anna Nozzoli). Roma: Bulzoni Editore, 2001, pp. 13-14.
} 
primordial seria - à luz do giro de pensamento a que referimos - a queda da metáfora animal como construção simbólica primordial do humano. Isso explicaria, ao menos parcialmente, a decadência do bestiário e da fábula moral e a abertura de novas formas de representação, mais próximas da mutação do que das configurações cristalizadas que Jacques Derrida (2008) chamou de "afabulações", ou seja, formas de adestramento antropomórfico, de submissão moralizadora, de domesticação. Já não se trataria, então, de "restituir a palavra" aos animais, como propõem as ficções de máscara animal, da fábula clássica até as autobiografias animais contemporâneas, mas de uma tarefa muito mais ambiciosa: explorar as possibilidades de uma literatura que busca novas formas de aproximação ideológica e metodológica ao imaginário animal. ${ }^{296}$

A obra de Pirandello insere-se nesse nicho, que ainda é uma zona cinzenta na passagem do século, e por isso, talvez, não se constitua numa "busca de novas formas de aproximação ideológica e metodológica ao imaginário animal", mas na identificação da criatividade do autor com um mundo que lhe é muito próximo, uma "necessidade de animalizar que está na origem da imaginação", como afirma Bachelard no perfil que traçou de Lautréamont $^{297}$, mas que certamente pode ser aplicado também a Pirandello.

A identificação inicial de Pirandello com sua origem grega e com as fábulas dará lugar, gradativamente, a uma forma própria de expressão em relação à utilização dos animais, que passam a assumir outras características na evolução de sua obra. Sem abandonar totalmente a fábula, Pirandello imprime aos animais que incorpora a suas narrativas uma complexidade que se apresenta sob aspectos diversos, capazes de sugerir os grandes temas da existência que constituem a alma de toda sua obra.

Identificam-se elementos constantes tanto em relação ao retículo temático que unifica a multiforme produção do escritor agrigentino e às particulares

\footnotetext{
296 YELIN, Julieta. "O giro animal na literatura de Wilson Bueno". In Deslocamentos críticos.São Paulo: Laboratório On Line de Crítica Literária, Núcleo de Audiovisual e Literatura, Itaú Cultural: babel, 2011, pp. 81-82.

${ }^{297}$ BACHELARD, Gaston. Lautréamont. Lisboa: Litoral Edições, 1989, p. 42.
} 
modalidades de relação estabelecidas por ele entre mundo animal e mundo humano, entre o "animal" e o "homem", quanto numa espécie de "tipização" simbólica dos animais, algumas vezes em bases convenciona is e populares, outras vezes completamente pessoais, quanto no jogo de retornos, retomadas e autocitação característico do laboratório pirandelliano. ${ }^{298}$

Para Robert Perroud, os animais representam, na obra de Pirandello, o espelho invertido do destino humano, e nessa relação

O homem é um agente extrínseco do destino da maior parte dos animais. Ele opera de fora, porque entre ele e os animais a comunicação só pode ser parcial e imperfeita. Quando ele crê que estabelece com eles uma relação mais íntima e atribui aos animais intenções da mesma natureza que as suas, ele se engana grosseiramente. Ele os alimenta e os mata ${ }^{299}$ [...]; ele os aprisiona ou os liberta ${ }^{300}[\ldots]$; ele os salva, ao menos momentaneamente ${ }^{301}$ [...]; os trata com amizade, os maltrata. [...] Em suma, os homens deles se servem como instrumentos à sua disposição. [...] Reciprocamente, o animal é um agente extrínseco ao destino do homem, e isso não somente quando sua intervenção modifica materialmente e diretamente esse destino [...]. Pois a aventura do homem é muito menos estritamente ligada ao funcionamento da natureza do que aquela dos outros seres vivos; o sistema de casualidades que aprisiona o homem é mais vasto, mais complexo, mais misterioso e sem dúvida também mais feroz. ${ }^{302}$

\footnotetext{
298 “elementi costanti si individuano sia in ordine al reticolo te matico che unifica la mu ltiforme produzione dello scrittore agrigentino e alle particolari modalità relazionali da lui stabilite tra mondo animale e mondo umano, tra la "bestia" e 1" "uomo", sia in una sorta di "tippizzazione" simbolica degli animali, a volte su basi convenzionali e popolari, altre volte del tutto personali, sia nel giuoco di ritorni, riprese e autocitazioni caratteristico del laboratorio pirandelliano." BACCHERETI, Elisabetta. "L'animalesca filosofia”. Op. cit., p. 162.

299 "O Senhor dos Navegantes".

${ }^{300}$ Cadernos de Serafino Gubbio operador.

301 "Sorte de ser cavalo".

302 "L'ho mme est un agent extrinsèque du destin de la plupart des animaux; il opère du dehors, parce qu'entre lui et eux la communication ne peut être que très partielle et très imparfaite: et nous avons vu que lorsqu'il leur attribue des intentions de même nature que les siennes, il se leuvre grossièrement. Il les nourrit et il les les tue [...]; il les emprisonne ou les libère [...]; il les sauve, ou moins momentanément [...]; il les traite avec amitié, les brutalize. [...] Bref, em se servant d'eux comme d'instruments à sa discrétion. Réciproquement, l'animal est um agente extrinsèque du destin de l'homme, et cela pas seulement lorsque son intervention infléchit matèriellement et directement ce destin [...]. Car l'avventure de l'homme est beaucoup moins liée au fonctionnement de la nature que celle des autres vivants; le système de causalités qui emprisonne l'homme est plus vaste, plus complexe, plus mystérieux, et sans doute aussi plus feroce." PERROUD. Robert. "Le bestiaire pirandellien: miroir renversé du destin humain?". In "Revue des études italliennes", no. 23, n 3-4, Paris: M. Didier, 1997, pp. 267-268.
} 
O animal, na obra de Pirandello, surge naturalmente como qualquer personagem humano. Não se nota um especial esforço para sua introdução, nem uma simbologia específica, seja ela ligada ao tipo de animal ou ao tema tratado. Assim, apenas para dar alguns exemplos, o cão pode simbolizar a fidelidade ${ }^{303}$, a vingança ${ }^{304}$ ou ter uma conotação afetiva $^{305}$; o gato tanto pode representar a indiferença da natureza ${ }^{306}$ ou a ação do destino ${ }^{307}$. O que é diametralmente oposto ao bestiário medieval com seu simbolismo animal praticamente fixo, em que cada bicho carrega consigo um conceito estereotipado e constante através do tempo.

As fábulas pirandellianas, por si só contra-fábulas, transformam-se em parábolas e as parábolas evoluem para um tipo híbrido de narrativa exemplar ao se conjugarem com a filosofia, como em "A sorte de ser cavalo" (1935). Pirandello afasta-se paulatinamente das "afabulações" para criar um universo animal todo particular, voltado para as preocupações de sua poética, sem, no entanto, deixar de recorrer, quando necessário, às formas cristalizadas e à crendice popular. Realmente, não se trata de "dar voz aos animais", mas de considerá- los um recurso narrativo tão válido quanto o personagem humano.

Pirandello joga com possibilidades literárias, com relacionamentos, com confrontos, e nada melhor do que ter à disposição um "estoque” de personagens diversificados, maleáveis e sempre dispostos a fazer parte de suas novelas, como ele mesmo revela no prefácio a Seis personagens em busca de autor:

Há muitos anos (mas é como se fosse ontem) tenho a serviço de minha arte uma empregadinha muito esperta [...] que se chama Fantasia, ninguém poderá negar que ela seja um pouco bizarra. [...] Hoje aqui, amanhã ali,

\footnotetext{
303 "A fidelidade do cão" (1904).

304 “A vingança do cão" (1933).

305 "Bolinha e Mimi” (1905).

306 “O gato, um pintassilgo e as estrelas" (1917).

307 “A casa da agonia” (1935).
} 
diverte-se em me trazer para casa, para que eu delas retire novelas, romances e comédias, as pessoas mais descontentes do mundo, homens, mulheres, crianças, envolvidos em casos estranhos dos quais não encontram maneira de sair; contrariados em seus projetos; fraudados em suas esperanças; como os quais, em resumo, muitas vezes é verdadeiramente uma grande pena tratar. ${ }^{308}$

A fantasia é, sem dúvida, uma grande aliada do escritor, fantasia esta mediada pela realidade que ele procura decifrar. Seus personagens são retirados do mundo que o cerca, de notícias de jornais, de acontecimentos de que ele ouviu falar ou presenciou. Acontece que este mundo é repleto de animais e, aparentemente, o fato dos personagens serem humanos ou animais não entra em questão, desde que se enquadrem naquilo que ele pretende transmitir. Basta ver a "Advertência sobre os escrúpulos da fantasia" que Pirandello escreveu para rebater as críticas de inverosimilhança ao seu romance Ofalecido Mattia Pascal (1904) e que foi publicada como apêndice quando a obra foi reeditada em 1921, na qual ele compara os críticos com o zoólogo que, estudando o homem como espécie, representa-o de acordo com um modelo abstrato e geral. Mas os indivíduos concretos são diferentes uns dos outros e a arte representa uma verdade que prescinde da "verossimilhança zoológica".

Porém, se quisermos falar tão abstratamente como fazem esses críticos, não seria verdade que o homem raciocina (ou não raciocina, o que dá no mesmo) mais apaixonadamente quando sofre, precisamente porque quer conhecer a raiz dos seus sofrimentos, qual sua causa, e se é justo que o fizessem sofrer, ao passo que, quando está feliz, considera apenas essa felicidade sem raciocinar, como se gozá-la fosse um direito seu?

Os animais devem sofrer sem raciocinar. Quem sofre e raciocina (precisamente porque sofre), para esses senhores críticos, não é humano,

\footnotetext{
308 “A servizio della mia arte è da tanti anni (ma come fosse da ieri) una servetta sveltissima [...] che si chiama Fantasia, nessuno vorrà negare che non sia spesso alla bizzarra. [... ] Oggi qua; domani là. E si diverte a portarmi in casa, perché io ne tragga novelle e romanzi e commed ie, la gente più scontenta del mondo, uomini, donne, ragazzi, avvolti in casi strani da cui non trovan più modo a uscire; contrariati nei loro disegni; frodati nelle loro speranze; e coi quali insomma è spesso veramente una gran pen a trattare." PIRANDELLO, Luigi. "Come e perché ho scritto i 'Sei personaggi"”. In Saggi e interventi. Milano: Arnoldo Mondadori Editore, 2006, p. 1285.
} 
pois lhes parece que só um animal pode sofrer e que apenas sendo animal é que passa a ser humano. ${ }^{309}$

Alguns autores criaram dentro de suas obras bestiários específicos, ou seja, escreveram contos, novelas ou poesias ${ }^{310}$ com a intenção de reuni-los em bestiários, como, por exemplo, os já citados Julio Cortázar, Aldo Palazzeschi, Jorge Luis Borges, Apollinaire, Federico Tozzi e Dino Buzzati. Outros, criaram romances com animais como personagens, como George Orwell (A revolução dos bichos), Machado de Assis (Quincas Borba) ou Graciliano Ramos (Vidas secas), bem como os já citados Melville, Kipling e Tchechov, sem que houvesse a intenção de um bestiário, mesmo porque, muitas vezes, essas são suas únicas obras a incluírem animais.

Dessa forma, não há motivo para procurar organizar, a partir das novelas de Pirandello, um bestiário, seja ele moderno ou contemporâneo, já que a intenção do bestiário não faz parte das aspirações do autor. Aliás, a própria (des)organização das Novelas para um ano, como bem notou Giovanni Macchia, é um caos que tem aparência de cosmo, mas que se revela realmente $\operatorname{caos}^{311}$, e o mesmo se pode afirmar em relação ao seu "mundo animal". Na mesma Advertência, sustenta Pirandello:

O caos, se existe, é deliberado; o mecanismo, quando existe, é também deliberado. Não por mim, mas pela própria história, pelas próprias personagens, e logo se descobre que frequentemente é proposital e desvendado no próprio ato de construí-lo e estabelecê-lo. É a máscara para uma representação, o jogo dos papéis; aquilo que desejamos ou devemos ser;

\footnotetext{
309 "Ma volendo parlare così astrattamente come codesti critici fanno, non è forse vero che mai l'uomo tanto appassionatamente ragiona (o sragiona, che è lo stesso), come quando soffre, perché appunto delle sue sofferenze vuol veder la radice, e chi gliele ha date, e se e quanto sia stato giusto il dargliele; mentre, quando gode, si piglia il godimento e non ragiona, co me se il godere fosse suo diritto? /Dovere delle bestie è il soffrire senza ragionare. Chi soffre e ragiona (appunto perché soffre), per quei s ignori critici non è u mano; perché pare che, chi soffra, debba esser soltanto bestia, e che soltanto quando sia bestia, sia per essi umano." PIRANDELLO, Luigi. "Avvertenza sugli scrupoli della fantasia". In Il fu Mattia Pascal. Tutti i romanzi. Milano: Arnoldo Mondadori Editore, 2003, p. 581.

${ }^{310}$ Note-se que o Bestiário é mais adequado à narrativa curta ou à poesia, pois demanda uma certa variedade de animais dificilmente reuníveis em um romance, por exemplo.

${ }^{311}$ Ver nota 60.
} 
aquilo que parecemos ser aos outros; enquanto o que somos, até certo ponto, nem nós mesmos sabemos. É metáfora desajeitada e incerta de nós mesmos; a construção, frequentemente complexa, que fazemos de nós mesmos ou que os outros fazem de nós. ${ }^{312}$

A presença dos animais é tão rica e variada nas novelas de Pirandello, que parece resistir a qualquer tentativa de organização, não por falta de habilidade ou conhecimento de quem a tenta, mas pela impossibilidade de se transformar o caos em cosmo. Como afirma Elisabetta Bacchereti:

O imaginário zoomorfo pirandelliano não se torna criativamente autônomo na configuração de um "bestiário" organicamente concebido como tal, mas permanece encapsulado, tão disperso quanto invasivo, nas construções narrativas, e somente delas retira sua razão de sentido. ${ }^{313}$

O fato é que não é produtivo tentar organizar as novelas de Pirandello em forma de bestiário, nem mesmo fazer um inventário dos animais por ele utilizados, pois resultaria numa tediosa lista de nomes ou num novelo com várias pontas soltas. O que permanece da leitura dessas novelas é que o animal em Pirandello é um personagem que age e se comporta como um personagem de Pirandello, mas, ao contrário do personagem humano, mostra a sua própria face, sem disfarces, sem meios termos e sem máscaras. Dessa forma, a máscara animal configura-se como um falso paradoxo, uma "metáfora desajeitada e incerta": a falsa metáfora do homem que frequentemente esquece sua natureza animal.

\footnotetext{
312 “L'arruffìo, se c'è, dunque è voluto; il macchinis mo, se c'è, dunque è voluto; ma non da me: bensì dalla favola stessa, dagli stessi personaggi; e si scopre subito, difatti: spesso è concertato apposta e messo sotto gli occhi nell'atto stesso di concertarlo e di combinarlo: è la maschera per una rappresentazione; il giuoco delle parti; quello che vorremmo o dovremmo essere; quello che agli altri pare che siamo; mentre quel che siamo, non lo sappiamo, fino a un certo punto, neanche noi stessi; la goffa incerta metafora di noi; la costruzione, spesso arzigogolata, che facciamo di noi, o che gli altri fanno di noi." PIRANDELLO, Luigi. Op. cit., pp. 583584.

313 “L'imagery zoomorfa pirandelliana non si rende creativamente autonoma nella stilizzazione di un 'bestiario' organicamente concepito come tale, ma rimane incapsulata, tanto dispersa quanto invadente, nelle costruzioni narrative, da quelle sole trovando la sua ragione di senso." BACCHERETI, Elisabetta. Op. cit., p. 163.
} 
<smiles>C1=[Ge]=[GeH][As]1</smiles> 


\section{REFERÊNCIAS BIBLIOGRÁFICAS}

\section{OBRAS DE LUIGI PIRANDELLO}

Aforismi. Milano: BUR, 2007.

Carteggi inediti. A cura di S. Zapulla Muscarà. Roma: Bulzoni, 1980.

Carteggi inediti: con Ojetti, Albertini, Orvieto, Novaro, De Gubernatis, De Filippo. Sarah Zappulla Muscarà (org.). Roma: Bulzoni, 1980.

Lettere giovanili da Palermo e da Roma, 1886-1889. Roma: Bulzoni, 1993.

Maschere nude. Milano: Arnoldo Mondadori Editore, 4 vol., 1993.

Non parlo di me. Como-Pavia: Ibis, 2010.

Novelle per un anno. Edizione "I Meridiani”" a cura di Mario Costanzo. Milano: Arnoldo Mondadori Editore, 3 vol., 2007.

Saggi e interventi. Edizione "I Meridiani" a cura di Ferdinando Taviani. Milano: Mondadori, 2006.

Saggi, poesie e scritti varii. Milano: Arnoldo Mondadori Editore, 1993.

Tutti i romanzi. Arnoldo Mondadori Editore, 2 vol., 1993.

\section{OBRAS SOBRE PIRANDELLO}

AA. VV. "Revue des etudes italiennes", n 3-4, Paris: M. Didier, 1997.

AA. VV. Gli scrittori d'Italia. Il patrimonio e la memoria della tradizione letteraria come risorsa primaria. Atti dell'XI congresso dell'ADI - Napoli, 26-29 settembre 2007, a cura di C.A. Adesso, V. Caputo e O. Petraroli. Ascoli Piceno: Graduus, 2008.

AA. VV. Il punto su Pirandello (a cura di Franca Angelini). Roma-Bari: Editori Laterza, 1997. 
AA. VV. Intorno a Pirandello: percorsi e interpretazioni (a cura di Adriana Dentone e Andrea Contini). Genova: Le Mani, 2008.

AA. VV. Le passion di Pirandello. Atti del Convegno Internazionale Lovanio - Anversa, 1112 maggio 2007. Firenze: Franco Cesati Editore, 2010.

AA. VV. Luigi Pirandello. Roma: Istituto Poligrafico e Zecca dello Stato, 1995.

AA. VV. Pirandello e la lingua (a cura di Enzo Lauretta). Atti del XXX Convegno Internazionale, Agrigento 1-4 dicembre 1993. Milano: Mursia, 1994.

AA. VV. Pirandello. A collection of critical essays. New Jersey: Prentice-Hall, Inc., 1972.

AA. VV. Pirandello. Quaderni di Studi Pirandelliani 1. Roma: Beniamino Carucci Editore, 1973.

AA.VV. I segni e la storia. Studi e testimonianze in onore di Giorgio Luti. Firenze: Casa Editrice Le Lettere, 1996.

AA.VV. Le novelle di Pirandello. Agrigento:Edizioni del centro Nazionale di Studi Pirandelliani, 1980.

ALAJMO, Roberto. Le ceneri di Pirandello. Roma: Drago, 2008.

BARILLI, Renato. La linea Svevo-Pirandello. Milano: Arnoldo Mondadori Editore, 2003.

BARILLI, Renato. Pirandello. Una rivoluzione culturale. Milano: Arnoldo Mondadori Editore, 2005.

BORSELliNO, Nino. Ritratto e immagini di Pirandello. Roma-Bari: Editori Laterza, 1991.

CAMILLERI, Andrea. Biografia del figlio cambiato. Milano: RCS Libri S.p.A., 2003.

CANTELMO, Marinella Di lemmi del riso e altri saggi su Pirandello. Ravenna. Longo Editore Ravenna, 2004.

CASTIGliOnE, Marina. Pirandello e la metafonesi. Due lettere inedite da Bonn. Palermo: Centro di Studi Filologici Siciliani, 2004.

D’AMICO, Maria Luisa Aguirre. Album Pirandello. Milano: Arnoldo Mondadori Editore, 1992.

D'INTINO, Franco. L'“antro della bestia”. Le Novelle per um anno di Luigi Pirandello. Caltanissetta: Salvatore Sciascia Editore, 1992.

DE CASTRIS, A. Leone. Storia di Pirandello. Bari: Editori Laterza, 1962. 
DE CASTRIS, Arcangelo Leone. Il decadentismo italiano. Bari: Editori Laterza, 1989.

DEGANI, Francisco. Pirandello "novellaro": da forma à dissolução. São Paulo: Nova Alexandria-Humanitas, 2009.

ECO, Umberto. Sobre os espelhos e outros ensaios. Trad. Beatriz Borges. Rio de Janeiro: Nova Fronteira, 1989.

GIOANOLA, Elio. Pirandello's story: la vita o si vive o si scrive. Milano: Jaca Booh SpA, 2007.

GIOVANARDI, Daniela. I lettori d'italiano in Germania. Tübingen, Gunter Narr Verlag, 1996.

GIUDICE, Gapare. Pirandello. Torino: UTET, 1980.

GRIMALDI, Emma. Il labirinto e il caleidoscopio. Percorsi di letture tra le "Novelle per un anno” di Luigi Pirandello. Soveria Mannelli: Rubbettino Editore, 2007.

GUARNA, Mario. Filosofia del lontano. La natura filosofica dell'umorismo in Pirandello. Roma: Bonanno Editore, 2010.

GUGLIELMINETTI, Marziano. Pirandello. Roma: Salerno Editrice, 2006.

LAURETTA, Enzo. Luigi Pirandello. Storia di un personaggio "fuori di chiave”, Milano: Mursia, 1950.

LAURETTA, Enzo. Pirandello umano e irreligioso, Milano: Gastaldi, 1954.

LUPERINI, Romano. Introduzione a Pirandello. Roma-Bari: Laterza, 1992.

LUPERINI, Romano. Pirandello. Roma-Bari: Editori Laterza, 2005.

MANOTTA, Marco. Luigi Pirandello. Milano: Bruno Mondadori, 1998.

MARZANO, Pasquale. Quando il nome è "cosa seria”. L'onomastica nelle novelle di Luigi Pirandello. Pisa: Edizioni ETS, 2010.

MAZZACURATI, Giancarlo. Pirandello nel romanzo europeo. Bolognga: Il Mulino, 1995.

MAZZALI, Ettore. Luigi Pirandello. Roma: La nuova Italia, 1974.

MELI, Piero. Luigi Pirandello. Pagine ritrovate. Caltanisseta-Roma: Salvatore Sciascia Editore, 2010. 
NOBILI, Claudia Sebastiana. La materia del sogno. Pirandello tra racconto e visione. Pisa: Giardini Editori e Stampatori, 2007.

ORSINI, François. Pirandello e l'Europa. Cosenza: Pellegrini Editore, 2001.

PUGLISI, Filippo. Pirandello e la sua lingua. Rocca San Casciano: Cappelli Editore, 1962.

PUGLISI, Filippo. L'arte di Luigi Pirandello. Messina-Firenze: Casa Editrice G. D’Anna, 1958.

PUPO, Ivan. Interviste a Pirandello. "Parole da dire, uomo, agli altri uomini". Soveria Mannelli: Rubbettino Editore, 2002.

RADCLIFF-UMSTEAD, Douglas. The mirror of our anguish. A study of Luigi Pirandello's narrative writings. New Jersey: Associated University Presses, 1978.

SCIASCIA, Anna Maria. Il gioco dei padri. Pirandello e Leonardo. Roma: Avagliano Editore, 2009.

SCIASCIA, Leonardo. Pirandello e la Sicilia. Caltanisseta-Roma: Salvatore Sciascia Editore, 1968.

STARKIE, Walter. Luigi Pirandello. New York,:E. P. Dutton \& CO., 1926.

TERRACINI, Benvenuto. Analisi stilistica. Milano: Feltrinelli, 1966.

TILGHER, Adriano. Studi sul teatro contemporaneo. Roma: Libreria di Scienze e Lettere, 1923.

TUSCANO, Pasquale. L'identità impossibile. L'opera di Luigi Pirandello. Napoli: Loffredo, 1989.

ZANGRILLI, Franco. Pirandello e i classici. Da Euripide a Verga. Fiesole: Edizioni Cadmo, 1995.

ZANGRILLI, Franco. Pirandello postmoderno? Firenze: Edizioni Polistampa, 2008.

ZANGRILLI, Franco. Il bestiario di Pirandello. Fossombrone: Metauro Edizioni, 2001.

ZANGRILLI, Franco. Pirandello. Presenza varia e perenne. Pesaro: Metauro Edizioni, 2007. 


\section{III - OBRAS SOBRE ANIMAIS E ZOOLITERATURA}

AA. VV. A tradição da fábula. De Esopo a La Fontaine (Maria Celeste Consolin Dezotti, org.) Brasília: Editora Universidade de Brasília. São Paulo: Imprensa Oficial do Estado de São Paulo, 2003.

AA. VV. Animali della letteratura italiana. (a cura di Gian Mari Anselmi e Gino Ruozzi ). Roma: Carocci Editore, 2009.

AA. VV. Bestiari del Novecento (a cura di Enza Biagini e Anna Nozzoli). Roma: Bulzoni Editore, 2001.

AA. VV. Deslocamentos críticos. São Paulo: Laboratório On Line de Crítica Literária, Núcleo de Audiovisual e Literatura, Itaú Cultural: Babel, 2011.

AA. VV. Favole, Apologhi e Bestiari (a cura di Gino Ruozzi). Milano: BUR, 2007.

AA. VV. Natura, Cultura, libertà (a cura di Francesco Russo). Roma: Armando Editore, 2010.

AA. VV. Pensar/escrever o animal. Ensaios de zoopoética e biopolítica. Florianópolis: Editora UFSC, 2011.

AA. VV. "Revue des études italliennes", no. 23, juillet-decémbre 1977, Paris: Librairie Marcel Didier.

AA. VV. Simbolismo animale e letterartura (a cura di Dora Faraci). Roma: Vecchiarelli Editore, 2003.

AA. VV. Studi e problemi di critica testuale. Vol. 3, out 1971, p. 318.

AELIANUS, Claudius. On the characteristics of animals. 3 vol. Trad. A. F. Schofield. Cambridge: Harvard University Press; London: William Heinemann Ltd, 1959.

AGAMBEN, Giorgio. L'aperto. L'uomo e l'animale. Torino: Bollati Boringhieri, 2002.

APOLliNAIRE, Guillaume. O bestiário ou o Cortejo de Orfeu. Trad. Alvaro Faleiros. São Paulo: Iluminuras, 1997.

ARISTÓ TELES. História dos Animais. 2 vol. Obras Completas. Trad. Maria de Fátima Souza e Silva. Lisboa: Imprensa Nacional-Casa da Moeda, 2006-2008. 
BERGER, John. Sobre o olhar. Trad. Lya Luft. Portugal: Editorial Gustavo Gili, 2003.

BIANCIOTTO, Gabriel. "Le Bestiaire dans la literature médiévale". Études de Langue et Littérature françaises de l'Université de Hiroshima. Hiroshima, n. 15, 2006.

BORGES, Jorge Luis. Ficções. São Paulo: Companhia das Letras, 2007.

BORGES, Jorge Luis. O livro dos seres imaginários. Trad. Heloisa Jahn. São Paulo: Companhia das Letras, 2008.

BRANCATI, Vitaliano. Racconti, teatro, scritti giornalistici. Milano: Arnoldo Mondadori Editore, 2003.

BUENO, Wilson. Jardim Zoológico. São Paulo: Iluminuras, 1999.

CHAGALL, Marc. Fábulasde La Fontaine. Trad. Mário Laranjeira. São Paulo: Estação Liberdade, 2004.

CORRÊA, Paula da Cunha. Um bestiário arcaico. Fábulas e imagens animais na poesia de Arquíloco. Campinas (SP): Editora Unicamp, 2010.

CORTÁZAR, Julio. Bestiario. Buenos Aires: Aguilar, Altea, Taurus, Alfaguara, 2011.

CROCE, Giulio Cesare. Leccellenza e trionfo del porco. Bologna: Pendragon, 2012.

DARWIN, Charles. A expressão das emoções no homem e nos animais. Trad. Leon de Souza Lobo Garcia. São Paulo: Companhia das Letras, 2000.

DARWIN, Charles. A origem das espécies. Trad. Eduardo Nunes Fonseca. São Paulo: Folha de São Paulo, 2010.

FONSECA, Pedro Carlos Louzada. Bestiário e discurso do gênero no descobrimento da América e na colonização do Brasil. Bauru (SP): Editora da Universidade do Sagrado Coração, 2011.

ISIDORO DE SEVILHA. Etimologias. Trad. Jose Oroz Reta e Manuel A. Marcos Casquero. Madrid: Biblioteca de Autores Cristianos, 2004.

KAFKA, Franz. Um médico rural. Trad.: Modesto Carone. São Paulo: Companhia das Letras, 1999.

LÚLIO, Raimundo. Livro das Bestas. São Paulo: Edições Loyola / Editora Giordano, 1990.

MACIEL, Maria Esther. O animal escrito. Um olhar sobre a zooliteratura contemporânea. São Paulo: Lumme Editor, 2002. 
MAINARDI, Danilo. Arbitri e galline. Le sorpprendenti analogie trai 1 mondo animale e il mondo umano. Milano: Arnoldo Monaddori Editore, 2004.

MORRIS, Desmond. O contrato animal. Trad. Lucia Simioni. Rio de Janeiro: Editora Record, 1990.

MORRIS, Desmond. O macaco nu. Trad. Hermano Neves. São Paulo: Círculo do Livro, 1967.

PALAZZESCHI, Bestie del 900. Il buffo integrale. Milano: Arnoldo Mondadori Editore, 2006.

PAOLIERI, Ferdinando. Uomini Bestie Paesi. Torino: Società Editrice Internazionale di Torino, 1936.

PLINIO EL VIEJO. História Natural. Trad. Antonio Fontán, Ana M Moure Casas e outros. Madrid: Editorial Gredos, 1995.

PULINA, Giuseppe. Animali e filosofi. Firenze: Giunti Editore, 2008.

ROSE, Michael. O espectro de Darwin. A teoria da evolução e suas implicações no mundo moderno. Trad. Vera Ribeiro. Rio da Janeiro: Jorge Zahar Editores, 2000.

TORGA, Miguel. Bichos. Coimbra (PT): Gráfica de Coimbra, 1980.

TOZZI, Federico. Barche capovolte, In Cose e Persone. Firenze: Vallecchi, 1981.

TOZZI, Federigo. Bestie. Firenze: Le lettere, 2011.

\section{IV - OBRAS DE REFERÊNCIA}

AA. VV. A personagem de ficção. São Paulo: Editora Perspectiva, 2000.

AA. VV. Metamorfoses. Antologia de contos. Trad. Marcos Martinho. São Paulo: Companhia das Letras, 2010.

ADORNO, Theodor W. Notas de literatura I. São Paulo: Editora 34, 2003.

ASOR ROSA, Alberto. La novella occidentale dalle origini ad oggi. Roma: Edizioni Moderne Canesi, 1960.

ASOR ROSA. Genus italicum. Torino: Einaudi, 1997. 
AUERBACH, Erich. Mimesis. São Paulo: Editora Perspectiva, 2001.

BACHELARD, Gaston. Lautréamont. Lisboa: Litoral Edições, 1989.

BAKHTIN, Mikhail. Estética da criação verbal. São Paulo: Martins Fontes, 2003.

BARTHES, Roland. O grau zero da escrita. São Paulo: Martins Fontes, 2004.

BENEDETTI, Carla. La soggettività nel racconto. Napoli: Liguori Editore, 1984.

BERGSON, Henri. O riso. Rio de Janeiro: Zahar Editores, 1983.

BERMAN, Marshall. Tudo que è sólido desmancha no ar. São Paulo: Companhia das Letras, 1986.

BONTEMPELLI, Massimo. L' avventura novecentista: selva polemica, 1926-1938: dal realismo magico allo stile naturale, soglia della terza epoca. Firenze: Vallecchi, 1938.

BRANCA, Vittore. Protagonisti nel novecento. Torino: Nino Aragno Editore, 2004.

CANDIDO, Antonio. Noções de análise histórico literária. São Paulo: Humanitas, 2005.

CARPEAUX, Otto Maria. História da literatura ocidental. 4 vol. Brasília: Edições do Senado Federal, 2008.

COMPAGNON, Antoine. O demônio da teoria. Literatura e senso comum. Belo Horizonte: Editora UFMG, 2010.

DEBENEDETTI, Giacomo. Italiani del novecento. Firenze: Giunti, 1995.

DEBENEDETTI, Giacomo. Il romanzo del Novecento. Milano: Garzanti, 1983.

DELEUZE, Gilles. Proust e os signos. Trad. Antonio Carlos Piquet e Roberto Machado. Rio de Janeiro: Forense-Universitária, 1987.

DERRIDA, Jacques. O animal que logo sou. (A seguir). Trad. Fábio Landa. São Paulo: Editora UNESP, 2002.

GENETTE, Gérard. Figure III. Discorso del racconto. Torino: Einaudi, 2006.

GOTLIB, Nádia Batella. Teoria do conto. São Paulo: Editora Ática, 2004.

GREIMAS, A. J. Sêmantica estrutural: método de pesquisa. Trad. Haquira Osakabe e Izidoro Blikstein. São Paulo: Editora Cultrix, 1976.

HEGEL, Georg Wilhelm Friedrich. Estética, II. Lisboa: Guimarães Editores, 1993. 
HORKENHEIMER, Max. Eclipse da razão. Trad. Sebastião Uchôa Leite. São Paulo: Centauro, 2002.

JOUVE, Vincent. A leitura. São Paulo: Editora UNESP, 2002.

LANNDOWSKI, Eric. Presença do outro. Trad. Mary Amazonas Leite de Barros. São Paulo: Perspectiva, 2012.

LE GOFF, Jaques. A civilização do ocidente medieval. Trad. José Rivair de Macedo. Bauru: Edusc, 2005.

LEITE, Ligia Chiapini Moraes, O foco narrativo. São Paulo: Editora Ática, 2005.

LESSING. G. E. Laocoonte ou sobre as fronteiras da pintura e poesia. Trad. Márcio Seligmann-Silva. São Paulo: Iluminuras, 2011.

LUPERINI, Romano. L'autocoscienza del moderno. Napoli: Liguori Editore, 2005.

MAYER, Arno J. A força da tradição. São Paulo: Companhia das Letras, 1990.

MERLEAU-PONTY, Maurice. Senso e non senso. Milano: Il Saggiatore, 2004.

NIETZSCHE, Friedrich. A gaia ciência. Trad: Antonio Carlos Braga. São Paulo: Editora Escala, 2008.

PABST, Walter. La novela corta en la teoría y en la creación literaria. Madrid: Editorial Gredos, 1972.

PETRONIO, Giuseppe. Racconto del novecento letterario in Italia 1890-1990, 2 vol. Milano: Oscar Mondadori, 2000.

PROPP, Vladimir. Morfologia do conto maravilhoso. Trad. Boris Schnaiderman e Jasna Paravich Sarhan. Rio de Janeiro: Forense-Universitária, 2006.

SAFRANSKI, Rüdiger. Heidegger: um mestre da Alemanha entre o bem e o mal. São Paulo: Geração Editorial, 2005.

SALINARI, Carlo. Miti e coscienza del decadentismo italiano. Milano: Feltrinelli Editore, 1984.

SALVIATI, Carla. Raccontare destini. La fiaba come materia prima dell' immaginario di ieri e di oggi. Trieste: Einaudi Ragazzi, 2002.

SEGRE, Cesare. Avviamento all'analisi del testo letterario. Torino: Einaudi, 1985.

SICILIANO, Enzo. Racconti italiani del Novecento. Milano: Mondadori, 2001 
STALLONI, Yves. Os gêneros literários. Trad. Flávia Nascimento. Rio de Janeiro: DIFEL, 2001 .

TELLINI, Gino. Il romanzo italiano dell'ottocento e novecento. Milano: Bruno Mondadori, 1998.

TODOROV. Tzvetan. As estruturas narrativas. São Paulo: Perspectiva, 2013. 


\section{Anexo A}

Novelas por ano de publicação. 


\begin{tabular}{|c|c|c|c|}
\hline & Título & $\begin{array}{c}\text { Primeira } \\
\text { publicação }\end{array}$ & Coletânea \\
\hline 1 & Capannetta & 1884 & Appendice \\
\hline 2 & La ricca & 1892 & Appendice \\
\hline 3 & Concorso per referendario al Consiglio di Stato & \multirow{7}{*}{1894} & Il vecchio Dio \\
\hline 4 & L'onda & & Appendice \\
\hline 5 & La signorina & & Appendice \\
\hline 6 & L'amica delle mogli & & Appendice \\
\hline 7 & Se... & & Scialle nero \\
\hline 8 & Le tre carissime & & Il vecchio Dio \\
\hline 9 & I galletti del bottajo & & Appendice \\
\hline 10 & "In corpore vili" & \multirow{4}{*}{1895} & Il vecchio Dio \\
\hline 11 & Il “no" di Anna & & Appendice \\
\hline 12 & Dialoghi fra il Gran Me e il piccolo me & & Appendice \\
\hline 13 & Il nido & & Appendice \\
\hline 14 & Natale sul Reno & \multirow{5}{*}{1896} & Appendice \\
\hline 15 & Chi fu? & & Appendice \\
\hline 16 & Sole e ombra & & La rallegrata \\
\hline 17 & Visitare gl'infermi & & Donna Mimma \\
\hline 18 & Sogno di Natale & & Appendice \\
\hline 19 & "Vexilla regis" & \multirow{6}{*}{1897} & Il viaggio \\
\hline 20 & La paura & & Appendice \\
\hline 21 & Il giardinetto lassù & & In silenzio \\
\hline 22 & Le dodici lettere & & Appendice \\
\hline 23 & Creditor galante & & Appendice \\
\hline 24 & Acqua e lì & & Tutt'e tre \\
\hline 25 & La scelta & & Appendice \\
\hline 26 & Padron Dio & & Una giornata \\
\hline 27 & Dono della Vergine Maria & \multirow{2}{*}{1899} & L'uomo solo \\
\hline 28 & La maestrina Boccarmè & & Tutt'e tre \\
\hline 29 & Scialle nero & \multirow{5}{*}{1900} & Scialle nero \\
\hline 30 & Alberi cittadini & & Appendice \\
\hline 31 & La paura del sonno & & La giara \\
\hline 32 & Lumìe di Sicilia & & Il vecchio Dio \\
\hline 33 & Prima notte & & Scialle nero \\
\hline
\end{tabular}




\begin{tabular}{|c|c|c|c|}
\hline 34 & Il "fumo" & \multirow{9}{*}{1901} & Scialle nero \\
\hline 35 & La levata del sole & & Il vecchio Dio \\
\hline 36 & Nenia & & La rallegrata \\
\hline 37 & Notizie dal mondo & & L'uomo solo \\
\hline 38 & Prudenza & & Appendice \\
\hline 39 & Il vecchio Dio & & Il vecchio Dio \\
\hline 40 & Con altri occhi & & La mosca \\
\hline 41 & E due! & & Scialle nero \\
\hline 42 & Marsina stretta & & Tutt'e tre \\
\hline 43 & Lontano & \multirow{15}{*}{1902} & La mosca \\
\hline 44 & Pallottoline! & & La giara \\
\hline 45 & Quand'ero matto... & & Il vecchio Dio \\
\hline 46 & Un goj & & La rallegrata \\
\hline 47 & Un invito a tavola & & Il vecchio Dio \\
\hline 48 & Un'altra allodola & & La giara \\
\hline 49 & Gioventù & & Il viaggio \\
\hline 50 & La berretta di Padova & & La mosca \\
\hline 51 & Il figlio cambiato & & Dal naso al cielo \\
\hline 52 & Tanino e Tanotto & & Il vecchio Dio \\
\hline 53 & Il dovere del medico & & La vita nuda \\
\hline 54 & Alla zappa! & & In silenzio \\
\hline 55 & Amicissimi & & Scialle nero \\
\hline 56 & Il corvo di Mìzzaro & & In silenzio \\
\hline 57 & Al valor civile & & Il vecchio Dio \\
\hline 58 & La disdetta di Pitagora & \multirow{8}{*}{1903} & Il vecchio Dio \\
\hline 59 & La signora Speranza & & Appendice \\
\hline 60 & Come gemelle & & Tutt'e tre \\
\hline 61 & Il marito di mia moglie & & Tutt'e tre \\
\hline 62 & La balia & & In silenzio \\
\hline 63 & Il ventaglino & & Scialle nero \\
\hline 64 & Pianto segreto & & Testi estravaganti \\
\hline 65 & Il tabernacolo & & Scialle nero \\
\hline 66 & Formalità & \multirow{9}{*}{1904} & Scialle nero \\
\hline 67 & Nel segno & & La vita nuda \\
\hline 68 & La veglia & & In silenzio \\
\hline 69 & La buon'anima & & La vita nuda \\
\hline 70 & Sua Maestà & & La rallegrata \\
\hline 71 & Le medaglie & & La mosca \\
\hline 72 & Una voce & & In silenzio \\
\hline 73 & La mosca & & La mosca \\
\hline 74 & La fedeltà del cane & & La vita nuda \\
\hline
\end{tabular}




\begin{tabular}{|c|c|c|c|}
\hline 75 & La Messa di quest'anno & \multirow{17}{*}{1905} & Appendice \\
\hline 76 & Il sonno del vecchio & & La mosca \\
\hline 77 & In silenzio & & In silenzio \\
\hline 78 & Fuoco alla paglia & & La vita nuda \\
\hline 79 & L'altro figlio & & In silenzio \\
\hline 80 & L'eresia catara & & La mosca \\
\hline 81 & I tre pensieri della sbiobbina & & La rallegrata \\
\hline 82 & Lo scaldino & & La mosca \\
\hline 83 & Senza malizia & & La vita nuda \\
\hline 84 & Di guardia & & L'uomo solo \\
\hline 85 & La casa del Granella & & La vita nuda \\
\hline 86 & Acqua amara & & La vita nuda \\
\hline 87 & Tirocinio & & La giara \\
\hline 88 & Pallino e Mimì & & La vita nuda \\
\hline 89 & Va bene & & In silenzio \\
\hline 90 & Le sorprese della scienza & & La mosca \\
\hline 91 & Guardando una stampa & & La giara \\
\hline 92 & L'uscita del vedovo & \multirow{7}{*}{1906} & La vita nuda \\
\hline 93 & Personaggi & & Aggiunta \\
\hline 94 & Richiamo all'obbligo & & La giara \\
\hline 95 & Tutto per bene & & La vita nuda \\
\hline 96 & La toccatina & & La vita nuda \\
\hline 97 & Personaggi & & Aggiunta \\
\hline 98 & Nel dubbio & & Dal naso al cielo \\
\hline 99 & Distrazione & \multirow{8}{*}{1907} & La vita nuda \\
\hline 100 & Tra due ombre & & La mosca \\
\hline 101 & La vita nuda & & La vita nuda \\
\hline 102 & Dal naso al cielo & & Dal naso al cielo \\
\hline 103 & La corona & & Dal naso al cielo \\
\hline 104 & Un cavallo nella luna & & Donna Mimma \\
\hline 105 & Pari & & La vita nuda \\
\hline 106 & Volare & & L'uomo solo \\
\hline 107 & Il guardaroba dell'eloquenza & 1908 & La giara \\
\hline 108 & L'ombrello & \multirow{8}{*}{1909} & Il viaggio \\
\hline 109 & Due letti a due & & La giara \\
\hline 110 & Stefano Giogli, uno e due & & Appendice \\
\hline 111 & Difesa del Mèola & & Scialle nero \\
\hline 112 & Mondo di carta & & La mosca \\
\hline 113 & La giara & & La giara \\
\hline 114 & L'illustre estinto & & La giara \\
\hline 115 & Il lume dell'altra casa & & Il viaggio \\
\hline
\end{tabular}




\begin{tabular}{|c|c|c|c|}
\hline 116 & Ignare & \multirow{14}{*}{1910} & Il viaggio \\
\hline 117 & Non è una cosa seria & & La giara \\
\hline 118 & L'uccello impagliato & & Il viaggio \\
\hline 119 & Musica vecchia & & Dal naso al cielo \\
\hline 120 & Benedizione & & Dal naso al cielo \\
\hline 121 & Pensaci, Giacomino! & & La giara \\
\hline 122 & Il professor Terremoto & & L'uomo solo \\
\hline 123 & Lo spirito maligno & & In silenzio \\
\hline 124 & La lega disciolta & & La giara \\
\hline 125 & Leviamoci questo pensiero & & Il viaggio \\
\hline 126 & Lo storno e l'angelo Centuno & & Dal naso al cielo \\
\hline 127 & Il viaggio & & Il viaggio \\
\hline 128 & La morta e la viva & & La giara \\
\hline 129 & "Leonora, addio" & & Il viaggio \\
\hline 130 & Paura d'esser felici & \multirow{11}{*}{1911} & Donna Mimma \\
\hline 131 & Felicità & & Il viaggio \\
\hline 132 & Zafferanetta & & Il viaggio \\
\hline 133 & L'uomo solo & & L'uomo solo \\
\hline 134 & La cassa riposta & & L'uomo solo \\
\hline 135 & I fortunati & & Scialle nero \\
\hline 136 & La patente & & La rallegrata \\
\hline 137 & Il libretto rosso & & Il viaggio \\
\hline 138 & La tragedia d'un personaggio & & L'uomo solo \\
\hline 139 & "Ho tante cose da dirvi..." & & Candelora \\
\hline 140 & Canta l'epistola & & La rallegrata \\
\hline 141 & I nostri ric ordi & \multirow{17}{*}{1912} & L'uomo solo \\
\hline 142 & Risposta & & Scialle nero \\
\hline 143 & L'avemaria di Bobbio & & La rallegrata \\
\hline 144 & Certi obblighi & & Dal naso al cielo \\
\hline 145 & Nenè e Ninì & & La rallegrata \\
\hline 146 & O di uno o di nessuno & & La rallegrata \\
\hline 147 & "Superior stabat lúpus" & & Dal naso al cielo \\
\hline 148 & La trappola & & L'uomo solo \\
\hline 149 & Il coppo & & L’uomo solo \\
\hline 150 & La verità & & L'uomo solo \\
\hline 151 & Maestro Amore & & Appendice \\
\hline 152 & Notte & & La rallegrata \\
\hline 153 & Chi la paga & & Dal naso al cielo \\
\hline 154 & L'imbecille & & La rallegrata \\
\hline 155 & Tu ridi & & Tutt'e tre \\
\hline 156 & I due compari & & Tutt'e tre \\
\hline 157 & Ciàula scopre la luna & & Dal naso al cielo \\
\hline
\end{tabular}




\begin{tabular}{|c|c|c|c|}
\hline 158 & Candelora & \multirow{14}{*}{1913} & Candelora \\
\hline 159 & Il bottone della palandrana & & Tutt'e tre \\
\hline 160 & La veste lunga & & L'uomo solo \\
\hline 161 & "Requiem aeternam dona eis, Domine" & & La rallegrata \\
\hline 162 & Quando s’è capito il gioco & & Una giornata \\
\hline 163 & Tutt'e tre & & Tutt'e tre \\
\hline 164 & L'abito nuovo & & Donna Mimma \\
\hline 165 & Nel gorgo & & Dal naso al cielo \\
\hline 166 & La Madonnina & & La mosca \\
\hline 167 & Male di luna & & Dal naso al cielo \\
\hline 168 & La rallegrata & & La rallegrata \\
\hline 169 & Da sé & & Candelora \\
\hline 170 & Rondone e Rondinella & & Donna Mimma \\
\hline 171 & Il capretto nero & & Donna Mimma \\
\hline 172 & I pensionati della memoria & \multirow{14}{*}{1914} & Donna Mimma \\
\hline 173 & La liberazione del re & & Tutt'e tre \\
\hline 174 & Mentre il cuore soffriva & & Candelora \\
\hline 175 & L'ombra del rimorso & & Tutt'e tre \\
\hline 176 & Il treno ha fischiato... & & L'uomo solo \\
\hline 177 & Sopra e sotto & & La rallegrata \\
\hline 178 & Filo d'aria & & Tutt'e tre \\
\hline 179 & Zia Michelina & & L'uomo solo \\
\hline 180 & Un matrimonio ideale & & Tutt'e tre \\
\hline 181 & Un ritratto & & Candelora \\
\hline 182 & Servitù & & Candelora \\
\hline 183 & La realtà del sogno & & Candelora \\
\hline 184 & La rosa & & Candelora \\
\hline 185 & Zuccarello distinto melodista & & Candelora \\
\hline 186 & La mano del malato povero & \multirow{6}{*}{1915} & Il viaggio \\
\hline 187 & Nell'albergo è morto un tale & & Candelora \\
\hline 188 & Romolo & & Candelora \\
\hline 189 & Visto che non piove... & & Scialle nero \\
\hline 190 & Il vitalizio & & Il vecchio Dio \\
\hline 191 & Colloqui coi personaggi & & Appendice \\
\hline 192 & Il signore della nave & \multirow{5}{*}{1916} & Candelora \\
\hline 193 & La carriola & & Candelora \\
\hline 194 & La camera in attesa & & Candelora \\
\hline 195 & I due giganti & & Appendice \\
\hline 196 & Piuma & & Candelora \\
\hline 197 & Donna Mimma & \multirow{3}{*}{1917} & Donna Mimma \\
\hline 198 & Il gatto, il cardellino e le stelle & & Donna Mimma \\
\hline 199 & La signora Frola e il signor Ponza suo genero & & Una giornata \\
\hline
\end{tabular}




\begin{tabular}{|c|c|c|c|}
\hline 200 & La cattura & \multirow{4}{*}{1918} & La giara \\
\hline 201 & Quando si comprende & & Donna Mimma \\
\hline 202 & La maschera dimenticata & & In silenzio \\
\hline 203 & La morte addosso & & In silenzio \\
\hline 204 & Jeri e oggi & \multirow{2}{*}{1919} & Dal naso al cielo \\
\hline 205 & Frammento di cronaca di marco Lecio & & Appendice \\
\hline 206 & Il pipistrello & \multirow{3}{*}{1920} & Scialle nero \\
\hline 207 & Rimedio: la Geografia & & Scialle nero \\
\hline 208 & Pena di vivere così & & In silenzio \\
\hline 209 & La distruzione dell'uomo & 1921 & La mosca \\
\hline 210 & La fede & \multirow{2}{*}{1922} & La mosca \\
\hline 211 & Niente & & La mosca \\
\hline 212 & Fuga & \multirow{3}{*}{1923} & Dal naso al cielo \\
\hline 213 & Ritorno & & Tutt'e tre \\
\hline 214 & Un po' di vino & & Tutt'e tre \\
\hline 215 & Resti mortali & \multirow{2}{*}{1924} & Donna Mimma \\
\hline 216 & Sedile sotto un vecchio cipresso & & Donna Mimma \\
\hline 217 & Pubertà & 1926 & Il viaggio \\
\hline 218 & Spunta un giorno & 1928 & Il viaggio \\
\hline 219 & Uno di più & \multirow{3}{*}{1931} & Berecche e la guerra \\
\hline 220 & Soffio & & Berecche e la guerra \\
\hline 221 & I muricciuoli, un fico, un uccellino & & Testi estravaganti \\
\hline 222 & Cinci & \multirow{2}{*}{1932} & Berecche e la guerra \\
\hline 223 & Lucilla & & Berecche e la guerra \\
\hline 224 & Sgombero & \multirow{2}{*}{1933} & Appendice \\
\hline 225 & La vendetta del cane & & Donna Mimma \\
\hline 226 & Berecche e la guerra & \multirow{4}{*}{1934} & Berecche e la guerra \\
\hline 227 & I piedi sull'erba & & Berecche e la guerra \\
\hline 228 & Di sera un geranio & & Berecche e la guerra \\
\hline 229 & Un'idea & & Berecche e la guerra \\
\hline 230 & Una giornata & \multirow{4}{*}{1935} & Una giornata \\
\hline 231 & La prova & & Una giornata \\
\hline 232 & La casa dell'agonia & & Una giornata \\
\hline 233 & Fortuna d'esser cavallo & & Una giornata \\
\hline 234 & Una sfida & \multirow{7}{*}{1936} & Una giornata \\
\hline 235 & Il chiodo & & Una giornata \\
\hline 236 & Vittoria delle formiche & & Una giornata \\
\hline 237 & Visita & & Una giornata \\
\hline 238 & La tartaruga & & Una giornata \\
\hline 239 & C'è qualcuno che ride & & Una giornata \\
\hline 240 & Effetti d'un sogno interrotto & & Una giornata \\
\hline 241 & Il buon cuore & 1937 & Una giornata \\
\hline
\end{tabular}


Anexo B

Referências bibliográficas das novelas citadas. 
PIRANDELLO, Luigi. Novelle per un anno. Edizione "I Meridiani" a cura di Mario Costanzo. Milano: Arnoldo Mondadori Editore, 3 vol., 2007. Exceto a novela "I muriccioli, un fico, un uccellino", que está em Le novelle di Pirandello. Agrigento: Edizioni del centro Nazionale di Studi Pirandelliani, 1980, pp. 208-210.

\begin{tabular}{|l|l|c|c|}
\hline \multicolumn{1}{|c|}{ Título } & \multicolumn{1}{|c|}{ Título original } & Vol. & Páginas \\
\hline A “fumaça" & Il "fumo" & I & $50-93$ \\
\hline A amiga das esposas & L'amica delle moglie & III & $886-906$ \\
\hline A casa da agonia & La casa dell'agonia & III & $732-737$ \\
\hline A escolha & La scelta & III & $1033-1037$ \\
\hline A fidelidade do cão & La fedeltà del cane & I & $347-358$ \\
\hline A libertação do rei & La liberazione del re & II & $405-415$ \\
\hline A luz da outra casa & Il lume dell'altra casa & II & $384-393$ \\
\hline A mosca & La mosca & I & $827-837$ \\
\hline À noite um gerânio & Di sera un geranio & III & $676-679$ \\
\hline A onda & L'onda & III & $808-845$ \\
\hline A pirueta & La rallegrata & I & $474-481$ \\
\hline A prova & La prova & III & $727-732$ \\
\hline A rica & La ricca & III & $796-807$ \\
\hline A senhora Frola e o senhor Ponza, seu genro & La signora Frola e il signor Ponza, suo genero & III & $772-781$ \\
\hline A senhorita & La signorina & III & $846-885$ \\
\hline A tartaruga & La tartaruga & III & $744-752$ \\
\hline A vingança do cão & La vendetta del cane & II & $656-667$ \\
\hline Alguém está rindo & C'è qualcuno che ride & III & $689-695$ \\
\hline Andorinho e Andorinha & Rondone e Rondinella & II & $669-674$ \\
\hline
\end{tabular}




\begin{tabular}{|l|l|c|c|}
\hline Ao valor civil & Al valore civile & II & $761-769$ \\
\hline As muretas, uma figueira, um passarinho & I muricciolli, un fico, un uccellino & & \\
\hline Berecche e a guerra & Berecche e la guerra & III & $573-622$ \\
\hline Bolinha e Mimi & Pallino e Mimì & I & $285-298$ \\
\hline Choupana - Farsa siciliana & Capanetta - Bozzetto siciliano & III & $791-795$ \\
\hline Ciàula descobre a lua & Ciàula scopre la luna & $456-464$ \\
\hline Cinci & Cinci & III & $667-675$ \\
\hline Despejo & Sgombero & III & $1208-1214$ \\
\hline Distração & Distrazione & I & $464-469$ \\
\hline Efeitos de um sonho interrompido & Effetti d'un sogno interrotto & III & $684-688$ \\
\hline Fuga & Fuga & II & $440-445$ \\
\hline Limões da Sić́lia & Lumie di Sicilia & II & $904-918$ \\
\hline Lucilla & Lucilla & III & $654-660$ \\
\hline Mal de lua & Male di luna & II & $486-495$ \\
\hline Medo de ser feliz & Paura d'esser felice & II & $697-705$ \\
\hline Mundo de papel & Mondo di carta & I & $1019-1028$ \\
\hline Não é uma coisa séria & Non è uma cosa seria & III & $123-131$ \\
\hline Nené e Nini & Nenè e Niǹ̀ & I & $616-625$ \\
\hline Notícias do mundo & Notizie del mondo & I & $784-815$ \\
\hline O alvará & La patente & I & $567-576$ \\
\hline O bom coração & Il buon cuore & III & $738-743$ \\
\hline O carrinho de mão & La carriola & III & $553-561$ \\
\hline O corvo de Mìzzaro & Il corvo di Mìzzaro & II & $143-148$ \\
\hline O espírito maligno & Lo spirito maligno & II & $170-179$ \\
\hline O estorninho e o Anjo Cento e Um & Lo storno e l'Angelo Centuno & II & $502-512$ \\
\hline O filho trocado & Il figlio cambiato & II & $31-54$ \\
\hline & & \\
\hline
\end{tabular}




\begin{tabular}{|l|l|c|c|}
\hline O gato, um pintassilgo e as estrelas & Il gatto, um cardellino e le stelle & II & $649-655$ \\
\hline O ilustre extinto & L'illustre estinto & III & $142-158$ \\
\hline O jarro & La giara & III & $6-15$ \\
\hline O marido de minha mulher & Il marito di mia moglie & II & $323-330$ \\
\hline O morcego & Il pipistrello & I & $223-233$ \\
\hline O nãode Anna & Il no di Anna & III & $914-934$ \\
\hline O pássario empelhado & L'uccello impagliato & III & $363-373$ \\
\hline O prego & Il chiodo & III & $766-771$ \\
\hline O trem apitou & Il treno ha fischiato & I & $662-670$ \\
\hline Os galetos do barqueiro & I galletti del botajo & III & $907-913$ \\
\hline Os pés na grama & I piedi sull'erba & III & $661-666$ \\
\hline Outra cotovia & Un'altra allodola & III & $93-97$ \\
\hline Dádiva da Virgem Maria & Dono della Vergine Maria & I & $730-742$ \\
\hline Quem vai pagar & Chi la paga & II & $465-474$ \\
\hline O Senhor dos Navegantes & Il Signore della Nave & III & $418-427$ \\
\hline Sorte de ser cavalo & Fortuna d'esser cavallo & III & $753-759$ \\
\hline Tirocínio & Tirocinio & III & $132-141$ \\
\hline Um a mais & Uno di più & III & $623-632$ \\
\hline Um cavalo na lua & Un cavallo nella luna & II & $682-689$ \\
\hline Um desafio & Una sfida & III & $761-765$ \\
\hline Uma ideia & Un'idea & III & $648-653$ \\
\hline Uma jornada & Una giornata & III & $782-788$ \\
\hline Visita & Visita & III & $696-701$ \\
\hline Vitória das formigas & Vittoria delle formiche & III & $702-708$ \\
\hline
\end{tabular}

